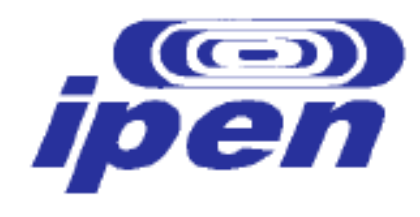

INSTITUTO DE PESQUISAS ENERGÉTICAS E NUCLEARES

Autarquia associada à Universidade de São Paulo

EFEITO DA MARCAÇÃO NA RESISTÊNCIA À CORROSÃO DE IMPLANTES ORTOPÉDICOS PRODUZIDOS EM AÇO INOXIDÁVEL ABNT NBR ISO 5832-1

EURICO FELIX PIERETTI

Dissertação apresentada como parte dos requisitos para obtenção do grau de Mestre em Ciências na Área de Tecnologia Nuclear - Materiais.

Orientadora: Dra. Isolda Costa 


\section{AGRADECIMENTOS}

A Deus, tão perto que se deixa encontrar. Por permitir a um engenheiro, através da investigação científica, caracterizar os seus materiais e, assim, se aproximar Dele.

À Prof ${ }^{a}$. Dra. Isolda Costa pela oportunidade, confiança, motivação, disponibilidade, pelos ensinamentos desde a época da graduação e, orientação indispensável para suscitar em mim um espírito de pesquisador.

Ao Engenheiro Tomaz Puga Leivas, da Comissão de Projetos do Instituto de Ortopedia e Traumatologia do Hospital das Clínicas da Faculdade de Medicina da USP, pelo material fornecido.

Ao Prof. Dr. Luís Frederico Pinheiro Dick, coordenador do Laboratório de Processos Eletroquímicos e Corrosão do Departamento de Engenharia Metalúrgica da UFRGS e, à engenheira Sara Matte Manhabosco, pelos ensaios de SVET.

À Dra. Maysa Terada, do Laboratório Nacional de Nanotecnologia em CampinasSP, pelas análises de SEM-FEG.

Ao Msc. Rogério Albuquerque Marques pela amizade e auxílio em parte das técnicas eletroquímicas empregadas nesta pesquisa.

Ao Departamento de Engenharia Metalúrgica e de Materiais da Escola Politécnica da USP pelas análises de microscopia eletrônica de varredura.

Ao IPEN e seus funcionários pela possibilidade de execução deste trabalho.

Aos meus pais, João e Sueli, e à minha avó, Julieta, pela dedicação e incentivo à minha formação. Por me fazerem crer que o altruísmo, a dignidade, a honestidade, o respeito e a alegria são valores essenciais ao desenvolvimento de um homem. 
"O homem retrata-se inteiramente na alma; para saber o que é e o que deve fazer, deve olhar-se na inteligência, nessa parte da alma na qual fulge um raio da sabedoria divina." 


\title{
EFEITO DA MARCAÇÃO NA RESISTÊNCIA À CORROSÃO DE IMPLANTES ORTOPÉDICOS PRODUZIDOS EM AÇO INOXIDÁVEL ABNT NBR ISO 5832-1
}

\author{
Eurico Felix Pieretti
}

RESUMO

Dentre as principais propriedades que devem ter os implantes ortopédicos, tem-se a resistência à corrosão. Os implantes passam por um processo de marcação antes de serem esterilizados, cuja função é prover a identificação e rastreabilidade do produto. Este trabalho teve o objetivo de avaliar o efeito de duas técnicas de marcação, mecânica e a laser, na resistência à corrosão do aço inoxidável austenítico ABNT NBR ISO 5832-1, um dos mais utilizados no Brasil na fabricação de próteses. Os ensaios eletroquímicos realizados constaram de monitoramento do potencial de corrosão em circuito aberto, espectroscopia de impedância eletroquímica, determinação das propriedades eletrônicas do filme passivo via abordagem de Mott-Schottky, medidas de polarização potenciodinâmica cíclica e a técnica eletroquímica de varredura com eletrodo vibrante (SVET), à temperatura de $37^{\circ} \mathrm{C}$. O eletrólito utilizado foi uma solução salina de fosfato tamponada de $\mathrm{pH}$ 7,4. Foram realizadas análises por microscopia óptica, microscopia eletrônica de varredura, SEM-FEG e, microscopia eletrônica de transmissão. Constatou-se que a marcação a laser diminui a resistência à corrosão por pite ao alterar significativamente as características do filme passivo, quando comparada à marcação mecânica e ao material sem marcações. Foram observadas inclusões de óxidos que foram colocadas em relevo pela dupla incidência do feixe de laser. $O$ ataque da matriz de aço no entorno das inclusões de óxidos promove a formação de micro-frestas entre esta e as inclusões favorecendo o crescimento e a propagação do pite. Este foi o mecanismo proposto para explicar a maior susceptibilidade à corrosão localizada nas áreas afetadas pela marcação a laser. 


\title{
EFFECT OF MARKING PROCESS ON THE CORROSION RESISTANCE OF ORTHOPEDIC IMPLANTS PRODUCED ON ISO 5832-1 STAINLESS STEEL
}

\author{
Eurico Felix Pieretti
}

\begin{abstract}
Among the most important properties that orthopedic implants should have, is the corrosion resistance. The implants undergo a process of marking before being sterilized, whose function is to provide identification and traceability. This study evaluated the effect of two marking techniques, mechanical and laser, on the corrosion resistance of austenitic ISO 5832-1 stainless steel, the most commonly used material in Brazil on the manufacture of implantable medical devices. The electrochemical tests performed consisted of monitoring the corrosion potential in open circuit, electrochemical impedance spectroscopy, determining the electronic properties of passive film via Mott-Schottky approach, and cyclic potentiodynamic polarization measurements and scanning vibrating electrode technique (SVET) at the temperature of $37^{\circ} \mathrm{C}$. The electrolyte used was a naturally aerated phosphate buffered solution, $\mathrm{pH} 7,4$. Analyzes were performed by optical microscopy, scanning electron microscopy, SEM-FEG, and transmission electron microscopy. The results indicated that the laser marking process increases the susceptibility to pitting corrosion by significantly altering the characteristics of the passive film, as compared to the material without marks and mechanically marked. Oxide inclusions were observed placed into relief by the double incidence of the laser beam. The attack of the steel matrix surrounding the inclusions of oxides promotes the formation of micro-crevices between this and the inclusions favoring the growth and propagation of pits. This was the mechanism proposed to explain the increased susceptibility to localized corrosion in areas affected by the laser marking process.
\end{abstract}




\section{SUMÁRIO}

Página

AGRADECIMENTOS...................................................................................... I

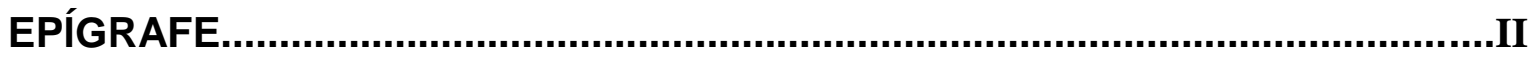

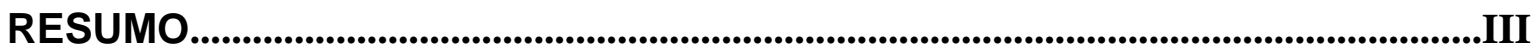

ABSTRACT

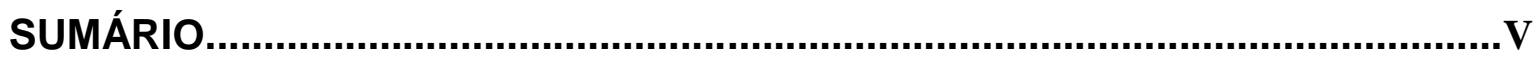

LISTA DE TABELAS.........................................................................................

LISTA DE FIGURAS............................................................................................................VIII

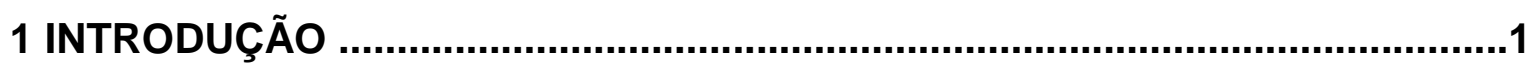

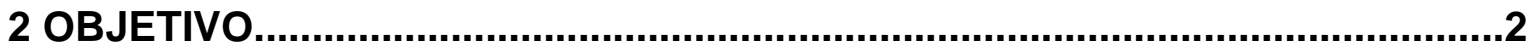

3 REVISÃO BIBLIOGRÁFICA

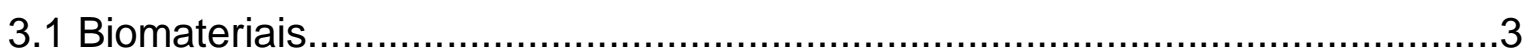

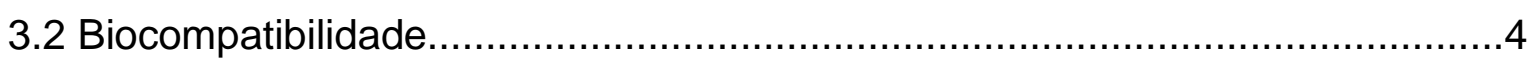

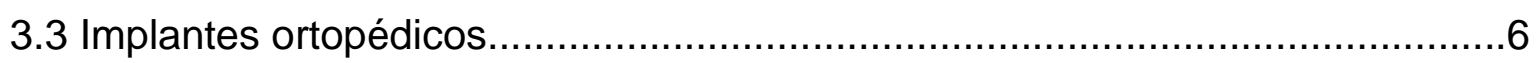

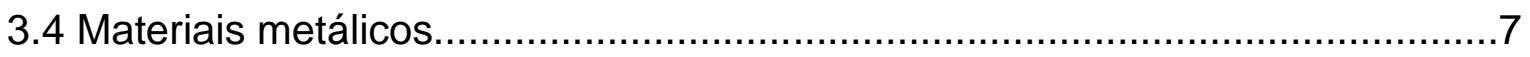

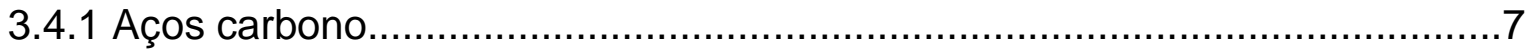

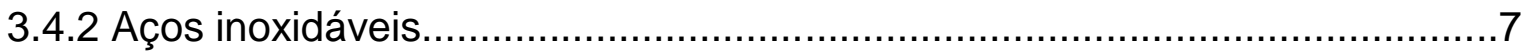

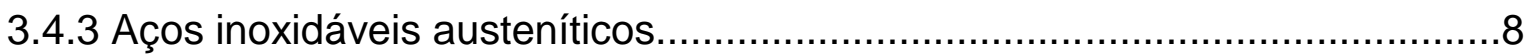

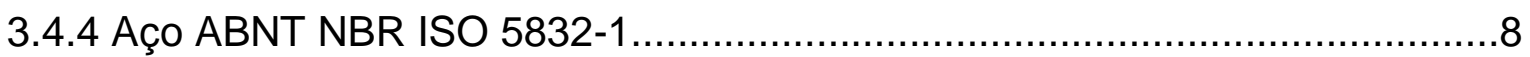

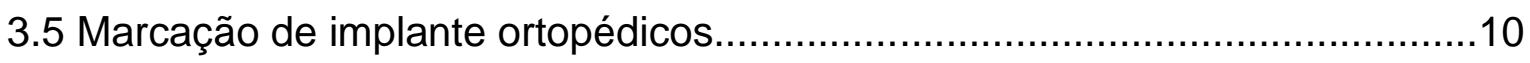

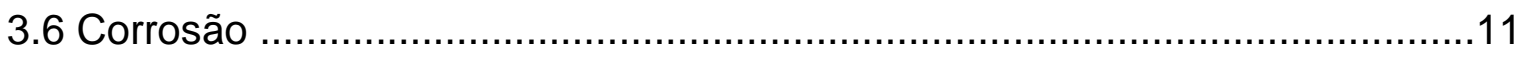

3.6.1 Mecanismos de corrosão - corrosão por pite...........................................12

3.7 Características do filme passivo em aços inoxidáveis ..................................13

3.7.1 Composição do filme passivo em aços inoxidáveis....................................13

3.7.2 Propriedades eletrônicas do filme passivo em aços inoxidáveis...................14

3.8 Espectroscopia de Impedância Eletroquímica (EIE) com Modelamento via Circuitos Elétricos Equivalentes (CEE) ......................................................19

3.9 Técnicas Eletroquímicas Localizadas - SVET ...........................................20

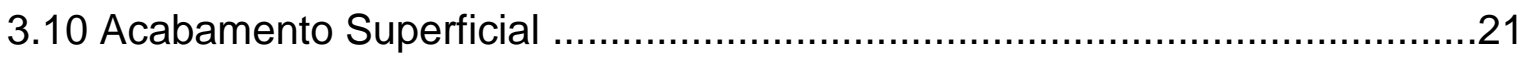

4 MATERIAIS E MÉTODOS ........................................................................23 


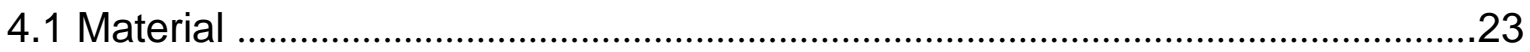

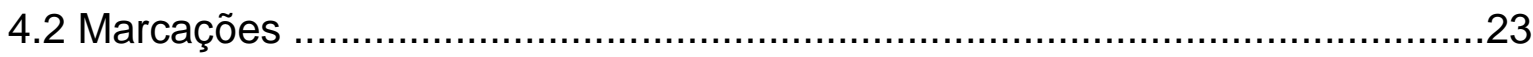

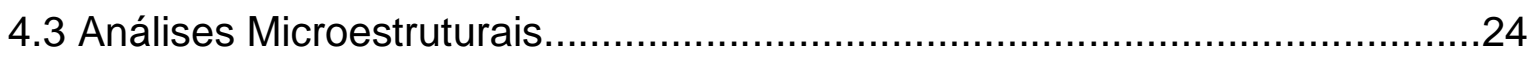

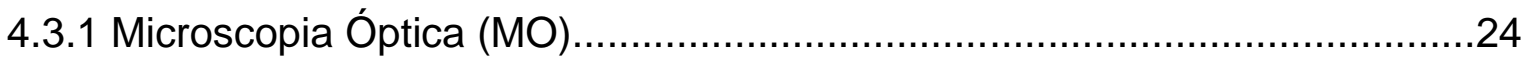

4.3.2 Microscopia Eletrônica de Varredura (MEV).............................................24

4.3.3 Microscopia de Alta Resolução (Field Emission Gun - FEG) .....................25

4.3.4 Microscopia Eletrônica de Transmissão (MET) …..................................25

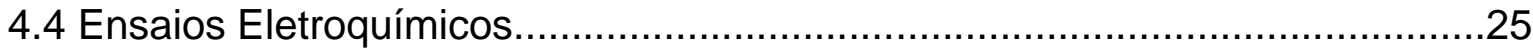

4.4.1 Potencial de Circuito Aberto (PCA) .................................................26

4.42 Espectroscopia de Impedância Eletroquímica (EIE) ..............................27

4.4.3 Polarização Potenciodinâmica Cíclica...................................................27

4.4.4 Propriedades eletrônicas do filme passivo - Abordagem de Mott-Schottky.28

4.4.5 Técnica Eletroquímica de Varredura com Eletrodo Vibrante (SVET)...........30

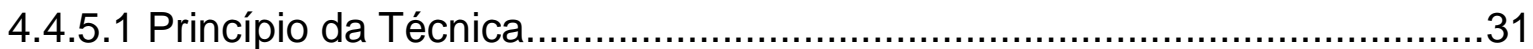

4.4.5.2 Elementos para aquisição de dados................................................33

4.4.5.3 Procedimento experimental utilizando-se SVET ..................................34

4.5 Caracterização de Fase Ferromagnética...................................................36

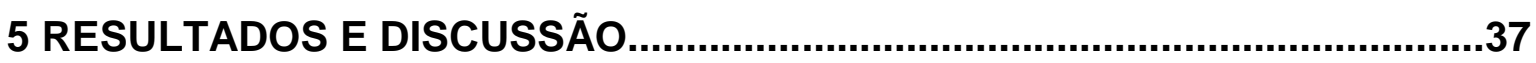

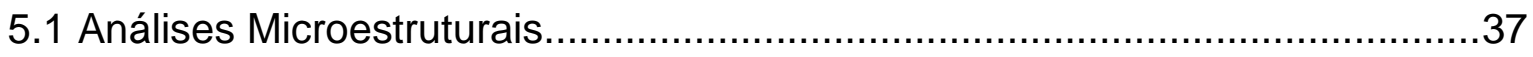

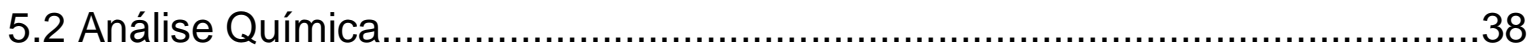

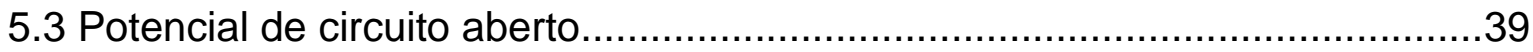

5.4 Espectroscopia de Impedância Eletroquímica.............................................42

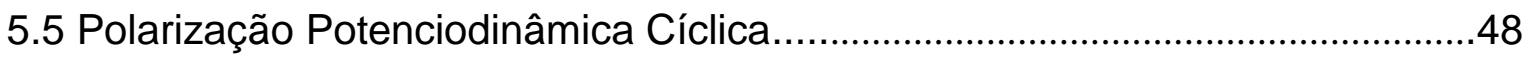

5.6 Propriedades eletrônicas do filme passivo - Abordagem de Mott-Schottky....53

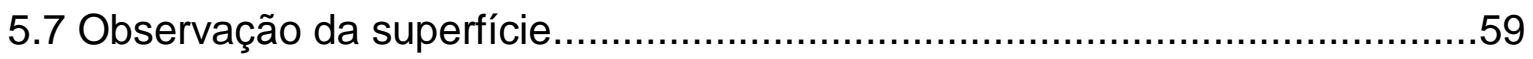

5.8 Características produzidas pelo laser na superfície do aço inoxidável............67

5.9 Técnica Eletroquímica de Varredura com Eletrodo Vibrante (SVET) ..............74

5.10 Técnicas de Caracterização Complementares..........................................86

5.11 Mecanismo de Corrosão............................................................................

6 DISCUSSÃO GERAL.................................................................................94

7 CONCLUSÕES...............................................................................................103

8 SUGESTÕES PARA TRABALHOS FUTUROS...........................................105

APÊNDICE ...................................................................................................106

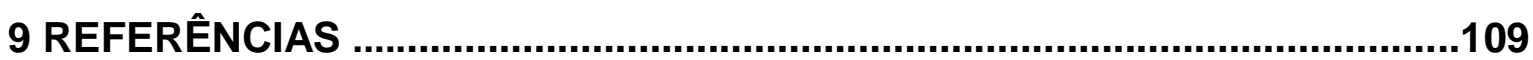




\section{LISTA DE TABELAS}

\section{Página}

Tabela 3. 1. Comparação da composição química do aço inoxidável austenítico ABNT NBR ISO 5832-1 com outros utilizados como biomateriais. 10

Tabela 4.1. Composição química da solução salina de fosfato tamponada .27

Tabela 5.1. Elementos químicos presentes na amostra do aço inoxidável ABNT NBR ISO 5832-1, pela técnica de espectroscopia de emissão ótica .38

Tabela 5.2. Valores dos parâmetros ajustados utilizando os circuitos mostrados na Figura 5.4.7 (a) e (b) para o aço inoxidável austenítico ABNT NBR ISO 5832-1, nas três condições estudadas 48

Tabela 5.3. Potenciais de corrosão, de pite e de quebra de filme para amostras com marcações a laser, mecânicas e sem marcações. .52

Tabela 5.4. Composição química obtida por EDS .65

Tabela 5.5. Composição química obtida por EDS na região da Figura 5.8.1.......68

Tabela 5.6. Composição química obtida por EDS na região da Figura 5.8.2.......69

Tabela 5.7. Composição química obtida por EDS na região da Figura 5.8.3.......70

Tabela 5.8. Composição química obtida por EDS na região da Figura 5.8.4.......71

Tabela 5.9. Composição química obtida por EDS na região da Figura 5.8.5.......72

Tabela 5.10. Condutividade e resistividade da solução PBS .74

Tabela 5.11. Medidas de alturas e profundidades (médias) geradas pela fusão do laser

Tabela 5.12. Parâmetros de difração obtidos por microscopia eletrônica de transmissão. 


\section{LISTA DE FIGURAS}

Página

Figura 3. 1. Implantes ortopédicos metálicos para o quadril..................................6

Figura 3. 2. Implantes ortopédicos metálicos femorais com marcações................11

Figura 3.3. Representação esquemática do processo de difusão através da camada dúplex do filme passivo .15

Figura 3.4. Representação esquemática da estrutura eletrônica dos óxidos formados em aços inoxidáveis e em ligas de $\mathrm{Fe}-\mathrm{Cr}$, através da abordagem de Mott-Schottky; onde $\mathrm{E}_{\mathrm{F}}$ é o nível de Energia de Fermi

Figura 4.1. Amostra laminada do aço utilizado neste trabalho, marcada pela técnica de raios laser.

Figura 4.2. Célula plana de três eletrodos utilizada para os ensaios eletroquímicos no Labcorts .26

Figura 4.3. Representação esquemática de linhas de corrente e de equipotencial numa amostra onde a área anódica encontra-se no centro .32

Figura 4.4. Esquema de interação entre os dispositivos do SVET. .33

Figura 4.5. Gaiola contendo a célula eletroquímica e o sistema de aquisição de imagens do SVET 35

Figura 4.6. Equipamentos utilizados no ensaio SVET. .35

Figura 4.7. Microeletrodo vibrante varrendo região marcada com o algarismo oito 36

Figura 5.1.1(a). Micrografia obtida por MEV da amostra do aço inoxidável estudado após ataque eletrolítico em ácido oxálico 37

Figura 5.1.1(b). Micrografia obtida por MEV da seção transversal da amostra marcada a laser após ataque eletrolítico em ácido oxálico. 38

Figura 5.3.1. Potencial de corrosão em circuito aberto variando ao longo do tempo em solução PBS, naturalmente aerada a $37^{\circ} \mathrm{C}$ nas condições: sem marcação, com marcações a laser e mecânicas

Figura 5.3.2. Potencial de corrosão em circuito aberto variando ao longo do tempo em solução PBS, naturalmente aerada a $37^{\circ} \mathrm{C}$ para a amostra marcada a laser 
Figura 5.4.1. Diagrama de Bode (ângulo de fase) obtido após PCA para o aço inoxidável austenítico ABNT NBR ISO $5832-1$ em PBS a $37^{\circ} \mathrm{C}$ nas três condições analisadas.

Figura 5.4.2. Diagrama de Bode (módulo de Z) obtido após PCA para o aço inoxidável austenítico ABNT NBR ISO 5832-1 em PBS a $37^{\circ} \mathrm{C}$ nas três condições analisadas

Figura 5.4.3. Diagrama de Nyquist obtido após PCA para o aço inoxidável austenítico ABNT NBR ISO $5832-1$ em PBS a $37^{\circ} \mathrm{C}$ para amostras marcadas a laser

Figura 5.4.4. Diagrama de Nyquist obtido após PCA para o aço inoxidável austenítico ABNT NBR ISO 5832-1 em PBS a $37^{\circ} \mathrm{C}$ para amostras marcadas pela técnica mecânica

Figura 5.4.5. Diagrama de Nyquist obtido após PCA para o aço inoxidável ABNT NBR ISO $5832-1$ em PBS a $37^{\circ} \mathrm{C}$ para amostras não marcadas 46

Figura 5.4.6. Diagrama de Nyquist obtido após PCA para o aço inoxidável austenítico ABNT NBR ISO $5832-1$ em PBS a $37^{\circ} \mathrm{C}$ para amostras as três condições analisadas.

Figura 5.4.7. Circuitos Elétricos Equivalentes (CEE) utilizados para ajustar os dados experimentais obtidos por EIE para o aço inoxidável austenítico ABNT NBR ISO 5832-1, para as condições: (a) sem marcação e com marcação a laser e (b) com marcação mecânica.

Figura 5.5.1. Curvas de polarização cíclica obtidas no sentido anódico para o aço inoxidável austenítico ABNT NBR ISO $5832-1$ em PBS a $37^{\circ} \mathrm{C}$ para amostras marcadas a laser

Figura 5.5.2. Curvas de polarização cíclica obtidas no sentido anódico para o aço inoxidável austenítico ABNT NBR ISO 5832-1 em PBS a $37^{\circ} \mathrm{C}$ para amostras marcadas mecanicamente.

Figura 5.5.3. Curvas de polarização cíclica obtidas no sentido anódico para o aço inoxidável austenítico ABNT NBR ISO $5832-1$ em PBS a $37^{\circ} \mathrm{C}$ para amostras não marcadas

Figura 5.5.4. Curvas de polarização cíclica obtidas no sentido anódico para o aço inoxidável austenítico ABNT NBR ISO 5832-1 em PBS a $37^{\circ} \mathrm{C}$ para as três condições de amostras avaliadas 
Figura 5.6.1. Gráficos de Mott-Schottky para amostras do aço inoxidável austenítico ABNT NBR ISO 5832-1 em PBS a $37^{\circ} \mathrm{C}$ para amostras não marcadas, imersas por dezessete horas.

Figura 5.6.2. Gráficos de Mott-Schottky para amostras do aço inoxidável austenítico ABNT NBR ISO 5832-1 marcadas mecanicamente, imersas por dezessete horas em PBS a $37^{\circ} \mathrm{C}$. .54

Figura 5.6.3. Gráficos de Mott-Schottky para amostras do aço inoxidável austenítico ABNT NBR ISO 5832-1 marcadas a laser, imersas por dezessete horas em PBS a $37^{\circ} \mathrm{C}$

Figura 5.6.4. Gráficos de Mott-Schottky do aço inoxidável austenítico ABNT NBR ISO 5832-1 para amostras nas três condições estudadas, imersas por dezessete horas em PBS a $37^{\circ} \mathrm{C}$ .56

Figura 5.6.5. Valores de doadores de carga no filme passivo, obtidos pelo gráfico de Mott-Schottky, na região de potenciais referentes à inclinação positiva (comportamento de um semicondutor tipo-n)

Figura 5.6.6. Valores de aceitadores de carga no filme passivo, obtidos pelo gráfico de Mott-Schottky, na região de potenciais referentes à inclinação negativa (comportamento de um semicondutor tipo-p).

Figura 5.7.1. Microscopia óptica do aço inoxidável ABNT NBR ISO 5832-1 com marcação mecânica, (a) antes do ensaio de polarização cíclica, (b) após o ensaio. Ataque via água régia.

Figura 5.7.2. Microscopia óptica do aço inoxidável ABNT NBR ISO 5832-1 com marcação a laser, atacada via água régia, antes do ensaio de polarização.

Figura 5.7.3 (a). Microscopia eletrônica de varredura do aço inoxidável ABNT NBR ISO 5832-1 com marcação a laser, antes do ensaio de polarização, sem ataque.

Figura 5.7.3.(b) Microscopia eletrônica de varredura do aço inoxidável ABNT NBR ISO 5832-1 com marcação a laser, antes do ensaio de polarização, sem ataque. A ampliação mostra a estrutura típica de bruta de fusão. 62 Figura 5.7.4.(a) Microscopia eletrônica de varredura do aço inoxidável ABNT NBR ISO 5832-1 com marcação a laser, após do ensaio de polarização cíclica. .63 Figura 5.7.4.(b) Microscopia eletrônica de varredura do aço inoxidável ABNT NBR ISO 5832-1 com marcação a laser, após do ensaio de polarização cíclica, onde há concentração da corrosão na região central da marcação. 
Figura 5.7.5. Microscopia eletrônica de varredura do aço inoxidável ABNT NBR ISO 5832-1 com marcação mecânica, após do ensaio de polarização cíclica, onde não há concentração de pites na região central da marcação

Figura 5.7.6. Microscopia eletrônica de varredura do aço inoxidável ABNT NBR ISO 5832-1 com marcação a laser, após do ensaio de polarização cíclica, onde $(A)$ : substrato, $(B)$ : região da marcação e $(C)$ : pite na região central da marcação do algarismo oito.

Figura 5.7.7. Microscopia eletrônica de varredura mostrando região de fresta formada na região central da gravação a laser do número oito em uma amostra do aço inoxidável ABNT NBR ISO 5832-1, sem ataque metalográfico 66

Figura 5.7.8. Ampliação da Figura 5.7.7. Região de fresta onde se evidencia a microestrutura austenítica do aço inoxidável e, apresenta grãos arrancados. Após polarização cíclica, sem ataque metalográfico.

Figura 5.8.1. Espectro de EDS para a região da matriz, cuja área selecionada está identificada pelo retângulo.

Figura 5.8.2. Espectro de EDS para a região de encontro do feixe de laser, cuja área selecionada está identificada pelo retângulo.

Figura 5.8.3. Espectro de EDS para a região fundida, cuja área selecionada está identificada pelo retângulo e corresponde à região fundida duas vezes. .70 Figura 5.8.4. Espectro de EDS para a região da matriz, cuja área analisada está identificada pelo ponto e corresponde à região fundida duas vezes pelo feixe de raios laser. .71

Figura 5.8.5. Espectro de EDS para a região da matriz, cuja área analisada está identificada pelo ponto e corresponde à região fundida duas vezes pelo feixe de raios laser.

Figura 5.8.6. Etch pit nas regiões adjacentes à fusão gerada pelo laser (zona termicamente afetada) após ataque por imersão em água régia. .72 Figura 5.8.7. (a) Etch pit nas regiões adjacentes à fusão gerada pelo laser (zona termicamente afetada) após ataque por imersão em água régia. (b) Ampliação do etch pit.

Figura 5.8.8. Etch pit nas regiões adjacentes à fusão gerada pelo laser (zona termicamente afetada) após ataque por imersão em água régia. .73

Figura 5.9.1. Região selecionada para análise, com detalhe para o microeletrodo utilizado. 
Figura 5.9.2. Mapa em 2D correspondente à região mostrada na Figura 5.9.1....75 Figura 5.9.3. Mapa em 3D correspondente à região mostrada na Figura 5.9.1 ...76 Figura 5.9.4. Região selecionada para análise, com detalhe para o microeletrodo utilizado. . .76

Figura 5.9.5. Mapa em 2D correspondente à região mostrada na Figura 5.9.4 ...77 Figura 5.9.6. Mapa em 3D correspondente à região mostrada na Figura 5.9.4...77 Figura 5.9.7. Região selecionada para análise, com detalhe para o microeletrodo utilizado, passando pelo centro do oito .78 Figura 5.9.8. Mapa em 2D correspondente à região mostrada na Figura 5.9.7 ....78 Figura 5.9.9. Mapa em 3D correspondente à região mostrada na Figura 5.9.7....79 Figura 5.9.10. Região selecionada para análise, com detalhe para o microeletrodo

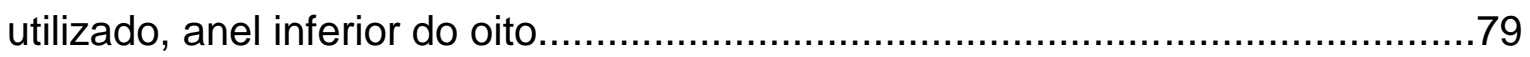

Figura 5.9.11. Mapa em 2D correspondente à região da Figura 5.9.10 ...............79 Figura 5.9.12. Mapa em 3D correspondente à região da Figura 5.9.10 ...............80 Figura 5.9.13. Mapa em 2D correspondente à região mostrada na Figura 5.9.10, após $24 \mathrm{~h}$ de imersão

Figura 5.9.14. (a) Mapa em 3D correspondente à região mostrada na Figura 5.9.10, após $17 \mathrm{~h}$ de imersão

Figura 5.9.14 (b) Mapa em 3D correspondente à região mostrada na Figura 5.9.10, após 24h de imersão

Figura 5.9.15. Mapa em 3D correspondente à região mostrada na Figura 5.9.10, amostra polarizada após 17h de imersão

Figura 5.9.16. Região selecionada para análise em seção transversal, com detalhe para o microeletrodo utilizado. .82

Figura 5.9.17. Mapa em 2D correspondente à região da Figura 5.9.16 .83

Figura 5.9.18. Mapa em 3D correspondente à região da Figura 5.9.16. .83 Figura 5.9.19. Região com janela isolada com fita adesiva, com detalhe para o microeletrodo utilizado.

Figura 5.9.20. Mapa em 2D correspondente à região mostrada na Figura 5.9.19, após $17 \mathrm{~h}$ de imersão

Figura 5.9.21. Mapa em 3D correspondente à região mostrada na Figura 5.9 .19 . .85

Figura 5.9.22. Microscopia óptica da zona termicamente afetada na seção transversal da amostra marcada pelo laser 
Figura 5.9.23. Seção transversal da amostra marcada pelo laser 86

Figura 5.10.1. Microscopia Eletrônica de Transmissão (MET) do aço inoxidável austenítico ABNT NBR ISO 5832-1, gravado a laser, evidenciando grande densidade de discordâncias e inclusões.

Figura 5.10.2. Microscopia Eletrônica de Transmissão (MET) do aço inoxidável austenítico ABNT NBR ISO 5832-1, gravado a laser, evidenciando um precipitado de óxido de silício. .88

Figura 5.10.3. Microscopia Eletrônica de Transmissão (MET) do aço inoxidável austenítico ABNT NBR ISO 5832-1, gravado a laser, evidenciando grande densidade de discordâncias

Figura 5.10.4. Microscopia Eletrônica de Transmissão (MET) do aço inoxidável austenítico ABNT NBR ISO 5832-1, gravado a laser .90

Figura 5.11. Imagem do interior de um pite nos primeiros estágios de formação indicando a presença de inclusões

Figura 6.1. Modelo físico utilizado para representar o comportamento eletroquímico do aço inoxidável austenítico ABNT NBR ISO 5832-1, (a) sem marcações e marcado via laser e, (b) com marcações mecânicas. .94

Figura 6.2. Diagrama de Mott-Schottky para as três condições estudadas. .98 


\section{INTRODUÇÃO}

O aumento da expectativa de vida da população e o crescente número de acidentes automobilísticos com lesões graves têm aumentado o número de cirurgias ortopédicas mundialmente. Os biomateriais substituem ou auxiliam certas partes do corpo humano para que estas possam desempenhar as suas funções adequadamente. Biomateriais são utilizados em implantes, próteses ou dispositivos médicos. Estes materiais devem ter uma composição química adequada e condição de superfície apropriada, de forma que não sejam rejeitados pelo corpo durante o período em que estiverem implantados.

A seleção do material a ser utilizado deve levar em consideração as propriedades físicas, químicas e mecânicas do material. As principais propriedades que devem ser observadas são: resistência mecânica, módulo de elasticidade, flexão e torção, resistência à fadiga, resistência à corrosão, rugosidade e permeabilidade. A corrosão é um fenômeno de superfície e, como tal, a condição da superfície em contato com o meio é de grande importância para esta propriedade.

Atualmente, vários materiais podem ser utilizados em implantes ortopédicos, sendo os metálicos os que apresentam as melhores propriedades mecânicas.

O processo de fabricação dos dispositivos médicos implantáveis metálicos é uma etapa importante da produção dos implantes, que pode ser via fundição, forjamento, usinagem, soldagem, ou via metalurgia do pó. Passam ainda por técnicas de limpeza, acabamento superficial, marcação e esterilização, seguindo os mais rígidos padrões de controle de qualidade.

Estes dispositivos são submetidos a algumas marcações que acabam por tornarem-se concentradores de tensões e locais em potencial para a origem de falhas que podem conduzir à fratura. Quando em contato com os tecidos humanos, sofrem desgastes e constantes riscos de corrosão, podendo causar hipersensibilidade, ou a necessidade de uma nova cirurgia para substituição. Consequentemente aumentam as despesas para os pacientes, convênios médicos e as instituições públicas de saúde. Por isso, torna-se necessário o constante avanço nos campos de pesquisa e desenvolvimento de biomateriais. 


\section{OBJETIVO}

O presente trabalho tem o objetivo de avaliar o efeito de duas técnicas de marcação, a laser e mecânica, na resistência à corrosão por pite de implantes metálicos; tomando para estudo o aço inoxidável ABNT NBR ISO 5832-1, atualmente o mais utilizado no Brasil para a confecção de implantes ortopédicos.

De acordo com a Agência Nacional de Vigilância Sanitária (ANVISA), ainda são escassas, no Brasil, pesquisas científicas que comprovem a influência das marcações empregadas nos dispositivos médicos implantáveis metálicos no tocante à resistência à corrosão. Deste modo, os resultados obtidos nesta pesquisa vão ao encontro deste anseio e poderão servir como base para a criação de uma normalização brasileira específica sobre as consequências das marcações em implantes. 


\section{REVISÃO BIBLIOGRÁFICA}

\subsection{Biomateriais}

O uso de materiais no corpo humano para reparar ou restaurar um tecido ou órgão danificado não é recente. Os primeiros indícios têm em torno de 4000 anos de existência, descrevendo o uso de suturas para reparos de feridas. Também por volta deste período, os relatos médicos das civilizações hindu, egípcia e grega citam transplantes de ossos de animais para seres humanos. Já os primeiros relatos de uso de materiais não biológicos são encontrados a partir do ano de 1550, com a utilização de fios de ouro para suturas [1]. Atualmente, os avanços nas áreas de pesquisa em engenharia e cirurgia têm possibilitado a reconstrução de várias partes do corpo humano utilizando-se biomateriais.

Segundo Williams [2], biomaterial é definido como qualquer substância ou combinação de substâncias, exceto fármacos, de origem natural ou sintética, que podem ser usadas durante qualquer período de tempo, como parte ou como sistemas que tratam, aumentam ou substituem quaisquer tecidos, órgãos ou funções do corpo.

Levando-se em consideração a resposta biológica causada pelos biomateriais nos tecidos corpóreos, podemos classificá-los em [1, 3]:

-Bioinertes: não provocam reação de corpo estranho no organismo e estão em contato direto com o tecido receptor. Exemplos: titânio, zircônia e alumina.

-Biotolerados: moderadamente aceitos pelo tecido receptor e geralmente envolvidos por tecido fibroso. Exemplos: aço inoxidável, ligas $\mathrm{Cr}$-Co e polimetilmetacrilato (PMMA).

-Bioativos: há ligação direta aos tecidos vivos devido aos íons, por exemplo: $\mathrm{Ca}^{+2}$ e/ou $\mathrm{PO}_{4}{ }^{-2}$ presentes nos substitutos ósseos, que favorecem uma ligação química com o tecido ósseo. Exemplos: hidroxiapatita (HAp) e biovidros.

-Reabsorvíveis: lentamente degradáveis e gradualmente substituídos pelos tecidos. Exemplos: fosfato tricálcio (TCP) e biovidros. 
Quanto à composição química, podem ser classificados em: metálicos, cerâmicos, poliméricos, compósitos e naturais. [1] Os metálicos são largamente usados em duas importantes áreas: ortopédica e de estimulação neuromuscular. As aplicações ortopédicas envolvem o uso do material para o reparo ou substituição de alguma parte do sistema esquelético. Na estimulação neural ou neuromuscular os biomateriais metálicos são usados em um sistema eletrônico a fim de prover uma estimulação elétrica para os tecidos. [4]

O desenvolvimento de biomateriais mostra-se fundamentalmente importante, no sentido em que proporciona uma melhoria no nível de vida das pessoas, representada por um aumento na expectativa de vida, na saúde em geral e no bem estar da população.

\subsection{Biocompatibilidade}

Segundo a literatura [1], a biocompatibilidade do material pode ser definida como um estado sinérgico (ou de mútua existência) entre o material e o ambiente fisiológico, ou seja, o material a ser utilizado não deve desencadear reações desfavoráveis no sistema biológico necessitando, ainda, desenvolver respostas teciduais adequadas aos sistemas hospedeiros. Um material biocompatível é aquele que desempenha adequadamente a função para a qual foi designado, em presença do ambiente fisiológico hostil.

A avaliação do desempenho biológico dos biomateriais é o campo principal de estudo da biocompatibilidade. Os testes de biocompatibilidade são de extrema importância no desenvolvimento de materiais para implantes, não apenas como critério que aprove ou rejeite um material ou dispositivo, mas como um conjunto de procedimentos que permite caracterizar corretamente o desempenho biológico de um material e estabelecer critérios para identificação, eliminação ou determinação de limites toleráveis de reações adversas para determinado material ou dispositivo [1]. Segundo Gibbons [3], o fato de ser compatível com órgãos ou tecidos vivos não implica que o material seja completamente inerte; pelo contrário, é mais provável que um grau de interação seja necessário para maior eficiência do mesmo. 
Associado à biocompatibilidade, o biomaterial precisa apresentar outra função denominada biofuncionalidade, ou seja, a capacidade de desempenhar apropriadamente a função para o qual foi projetado; assim, no caso dos implantes metálicos, a bioadesão será uma dessas propriedades desejáveis. A bioadesão é definida como a ligação ou interação em torno da região interfacial entre a superfície do implante (biomaterial estrutural) e as células e/ou tecido. A melhor bioadesão possível ocorre quando se tem a osteogênese, na qual ocorre uma união físico-química do material ao osso. Nesse tipo de união, o implante não pode ser separado por meios mecânicos do osso sem que haja fratura nestes.

De acordo com Lyman e Seare [1], a escolha de um material para a confecção de um implante deve responder a duas questões, a saber: qual é o efeito do material no corpo humano, (do nível celular até o dos sistemas); e qual é o efeito do corpo no implante. Avaliando-se estas questões pode-se ou não optar pela escolha de um determinado material, sabendo-se que o mesmo não apresentará reações adversas significativas aos órgãos ou tecidos adjacentes, tais como: irritações, inflamações agudas ou crônicas, infecções, dificuldades para cicatrizações e até mesmo efeitos da interação com produtos oriundos da biodegradação dos materiais.

Entre as características que dizem respeito ao efeito causado pelos implantes metálicos no corpo humano, têm-se a estrutura da superfície do metal, suas características mecânicas, tamanho e formato; e no que diz respeito ao efeito causado pelo corpo humano no implante, têm-se a existência de partículas de desgaste no meio fisiológico, o estado de hidratação deste meio, intensidade de esforços ou solicitações a que o corpo humano como um todo estará submetido e, consequentemente o implante, e a corrosão e oxidação da superfície, que são temas de interesse do presente trabalho.

Conforme Anderson [5], não se pode assegurar que um biomaterial biocompatível para determinada aplicação será igualmente biocompatível para outra área de aplicação. 


\subsection{Implantes ortopédicos}

Os implantes ortopédicos são projetados e fabricados de forma que, quando usados sob as condições e para os propósitos projetados, não comprometam a condição clínica ou a segurança de pacientes e, quaisquer riscos que possam ser associados com o uso de implantes sejam aceitáveis quando comparados aos benefícios para o paciente, além de compatíveis com um alto nível de proteção, saúde e segurança.

Os implantes podem ser divididos em duas categorias: dispositivos de fixação temporária ou permanente. O propósito dos dispositivos de fixação temporária é a estabilização da fratura do osso até a sua 'cicatrização' natural; já os dispositivos de fixação permanente são implantados no lugar do osso fraturado, substituindo-o [4]. As imagens a seguir, Figura 3.1, são exemplos de implantes ortopédicos metálicos.

De acordo com Anderson [5], para facilitar os testes de seleção do material apropriado para implante, deve-se considerar a natureza do contato do biomaterial com a região do organismo em que será utilizado e a duração deste contato.

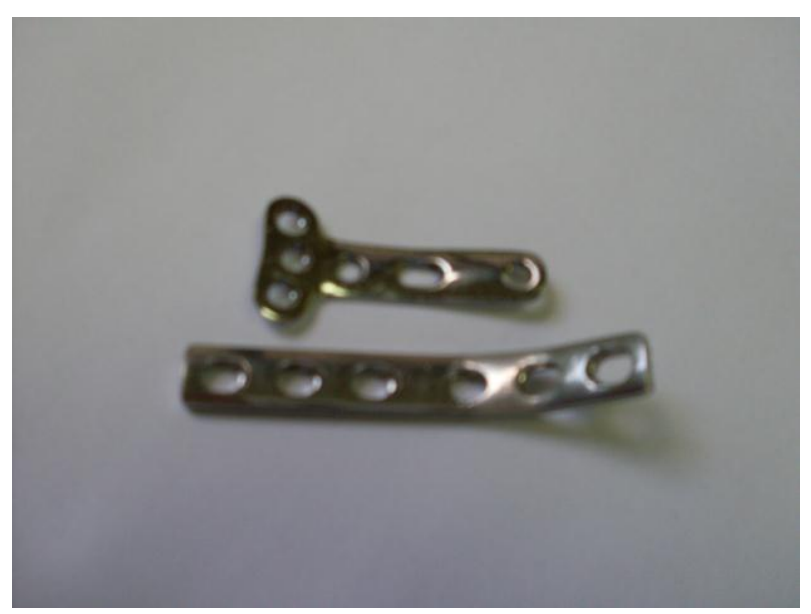

Figura 3. 1. Implantes ortopédicos metálicos para o quadril. 


\subsection{Materiais metálicos}

\subsubsection{Aços carbono}

O ferro apresenta três fases alotrópicas no estado sólido: $\alpha, \gamma, \delta$; ou ferrita, austenita e ferrita- $\delta$, que ocorrem nas seguintes faixas de temperaturas: ferrita: $<911{ }^{\circ} \mathrm{C}$, austenita: $911-1392{ }^{\circ} \mathrm{C}$, ferrita- $\delta$ : $1392-1536{ }^{\circ} \mathrm{C}$, ferro no estado líquido: $>1536^{\circ} \mathrm{C}$. (Ferro puro em condições de equilíbrio). [15]

A ferrita possui estrutura cristalina cúbica de corpo centrado (CCC), a ferrita- $\delta$ tem arranjo atômico similar à ferrita, mas apresenta distâncias interatômicas maiores, por causa das temperaturas elevadas. A austenita apresenta estrutura cristalina cúbica de faces centradas (CFC) e arranjo mais compacto do que a ferrita. A transição de uma estrutura para a outra implica em variação volumétrica, que pode gerar tensões residuais internas.

\subsubsection{Aços inoxidáveis}

Os aços inoxidáveis são ligas de ferro, cromo e outros elementos químicos, como níquel e molibdênio, entre outros; e possuem resistência à corrosão em vários ambientes. Esta propriedade conhecida como passividade é decorrente da formação de um filme protetor, que funciona como uma barreira entre o material e o meio em que está inserido. O cromo é o principal responsável por esta proteção devido a uma película resistente que forma em contato com o oxigênio do ar. [615]

As faixas de estabilidade das várias fases no aço são dependentes dos elementos de liga presentes nos mesmos. Um elemento de liga que é dissolvido preferencialmente em determinada fase, causa a sua estabilização, isto é, favorece a sua formação. Nos aços inoxidáveis, os elementos de liga são divididos em estabilizadores da ferrita e estabilizadores da austenita. [6-8, 15]

Os principais elementos de liga estabilizadores da ferrita são: $\mathrm{Cr}, \mathrm{Mo}, \mathrm{Si}$, $\mathrm{Nb}$ e Ti; e os principais estabilizadores da austenita são: C, Ni, Mn, N. 
Conforme a composição química e o tratamento térmico, os aços inoxidáveis podem ser classificados em: ferríticos, martensíticos, austeníticos, dúplex e endurecíveis por precipitação.

\subsubsection{Aços inoxidáveis austeníticos}

Estes aços possuem em sua composição teores de cromo entre $18-20 \%$ (em massa) e de níquel ao redor de $8 \%$ (em massa). O teor de carbono é normalmente inferior a $0,08 \%$ (em massa), mas os designados como "low carbon", tipo baixo carbono, possuem teor de carbono abaixo de 0,03\%. Este valor é considerado suficiente para se evitar a sensitização, que é a precipitação de carbonetos de cromo no contorno de grão, quando o aço inoxidável austenítico é aquecido na faixa de temperatura de $425^{\circ} \mathrm{C}-815^{\circ} \mathrm{C}$ e resfriado lentamente nesta mesma faixa de temperaturas; pode gerar um teor de cromo tão baixo que impossibilita a formação da película passiva, tornando o aço susceptível à corrosão intergranular.

Os aços inoxidáveis austeníticos apresentam estrutura cristalina cúbica de faces centradas (CFC) devido à adição de níquel e, têm caráter não magnético. [2-4,6-8,15]. Apresentam boa soldabilidade e elevada tenacidade, entre outras propriedades que justificam sua utilização na confecção de dispositivos médicos implantáveis.

\subsubsection{Aço ABNT NBR ISO 5832-1}

A importância da qualidade do material empregado na fabricação de implantes metálicos de uso ortopédico vem crescendo à medida que fica evidente a relação entre a composição química do metal e a ocorrência de falência do implante. Um dos aços inoxidáveis mais utilizados no Brasil é o aço inoxidável NBR ISO 5832-1 [6].

Atualmente, são aceitas para definição da composição química do aço inoxidável utilizado nesses implantes as normas da American Society for Testing and Materials (ASTM F138) e da International Organization for Standardization 
(ISO 5832-1), sendo esta última a mais recomendada, por exigir teores mais elevados de determinados elementos que conferem maior resistência ao metal.

Com relação à microestrutura do metal para o implante, as normas indicam que esta deve ser $100 \%$ austenítica e isenta de ferrita delta, por esta fase ferrítica ser ferromagnética. Além disso, a sua estrutura não deve possuir inclusões não metálicas (sulfetos, aluminatos, silicatos e óxidos globulares), que aumentam a suscetibilidade à ocorrência de corrosão localizada.

O tamanho de grão deve ter grau ASTM 4 ou superior (quanto menor o tamanho, maior o grau ASTM), para que não haja prejuízo das propriedades mecânicas e de resistência à fadiga do implante. Além de grãos finos, é desejável também que seu tamanho seja homogêneo ao longo de toda a peça [7].

Outros aços amplamente utilizados para a fabricação de implantes ortopédicos são: o aço inoxidável austenítico ASTM F139 (classe especial do aço AISI 316L para aplicações médicas), que na condição de recozido, apresenta algumas características como baixa resistência mecânica e maior suscetibilidade à corrosão localizada em comparação com o aço ABNT NBR ISO 5832-1, o que acaba por limitar o seu emprego mais amplo para aplicações ortopédicas de caráter permanente [8]; e o aço inoxidável austenítico ABNT NBR ISO 5832-9, com elevado de teor de $\mathrm{N}$ e pouco $\mathrm{Nb}$, que combina elevada resistência mecânica, mesmo quando recozido e alta resistência à corrosão localizada. Conforme Giordani [8] trata-se de um aço promissor no sentido de substituir o aço ASTM F139 na fabricação de implantes ortopédicos, sobretudo para aplicações mais críticas, envolvendo carregamentos mais severos e longos períodos de permanência no interior do corpo humano.

A composição química do implante metálico lhe confere a capacidade de formar, quando em contato com atmosfera úmida e oxigenada do organismo, um filme passivo sobre a sua superfície, que oferece resistência à corrosão. A tabela 3.1 apresenta uma comparação da composição química do aço utilizado neste trabalho com os seus similares. 
Tabela 3. 1. Comparação da composição química do aço inoxidável austenítico ABNT NBR ISO 5832-1com outros utilizados como biomateriais (\% em massa).

\begin{tabular}{cccc}
\hline \multirow{2}{*}{ ELEMENTOS } & INDUSTRIAL & \multicolumn{2}{c}{ MÉDICO / IMPLANTES } \\
\cline { 2 - 4 } & AISI 316L & ASTM F139 & $\begin{array}{c}\text { ABNT NBR } \\
\text { ISO 5832-1 }\end{array}$ \\
\hline $\mathbf{C}$ & 0,03 máx & 0,03 máx & 0,030 máx \\
\hline $\mathbf{S i}$ & 1,0 máx & 0,75 máx & 1,0 máx \\
\hline $\mathbf{M n}$ & 2,0 máx & 2,0 máx & 2,0 máx \\
\hline $\mathbf{P}$ & 0,045 máx & 0,025 máx & 0,025 máx \\
\hline $\mathbf{S}$ & 0,03 máx & 0,010 máx & 0,010 máx \\
\hline $\mathbf{N}$ & - & 0,10 máx & 0,10 máx \\
\hline $\mathbf{C r}$ & $16,0-18,0$ & $17,0-19,0$ & $17,0-19,0$ \\
\hline $\mathbf{M o}$ & $2,0-3,0$ & $2,25-3,0$ & $2,25-3,0$ \\
\hline $\mathbf{N i}$ & $10,0-14,0$ & $13,0-15,0$ & $13,0-15,0$ \\
\hline $\mathbf{C u}$ & - & 0,50 máx & 0,50 máx \\
\hline Ferro & Balanço & Balanço & Balanço \\
\hline
\end{tabular}

\subsection{Marcação de implantes ortopédicos}

Antes de serem esterilizados, os implantes são marcados pelo próprio fabricante. Esta marcação constitui uma informação ou conjunto de informações permanentes produzidas sobre uma superfície do implante de modo a prover a identificação e rastreabilidade do produto. Segundo Pourbaix et al. [9], tanto o tratamento superficial quanto a marcação podem influenciar a resposta óssea local, a consolidação óssea ou sua ausência, e a resistência à fadiga dos implantes. Essa resposta óssea local de implantes metálicos é afetada pela corrosão que, por sua vez, pode ser afetada pela presença de partículas estranhas, estado da superfície e outros fatores; colocando em risco a biocompatibilidade, mesmo na ausência de corrosão, ou afetar o contato entre os componentes do implante. A Figura 3. 2 apresenta exemplos de implantes ortopédicos com marcações indicadas pelas setas. 


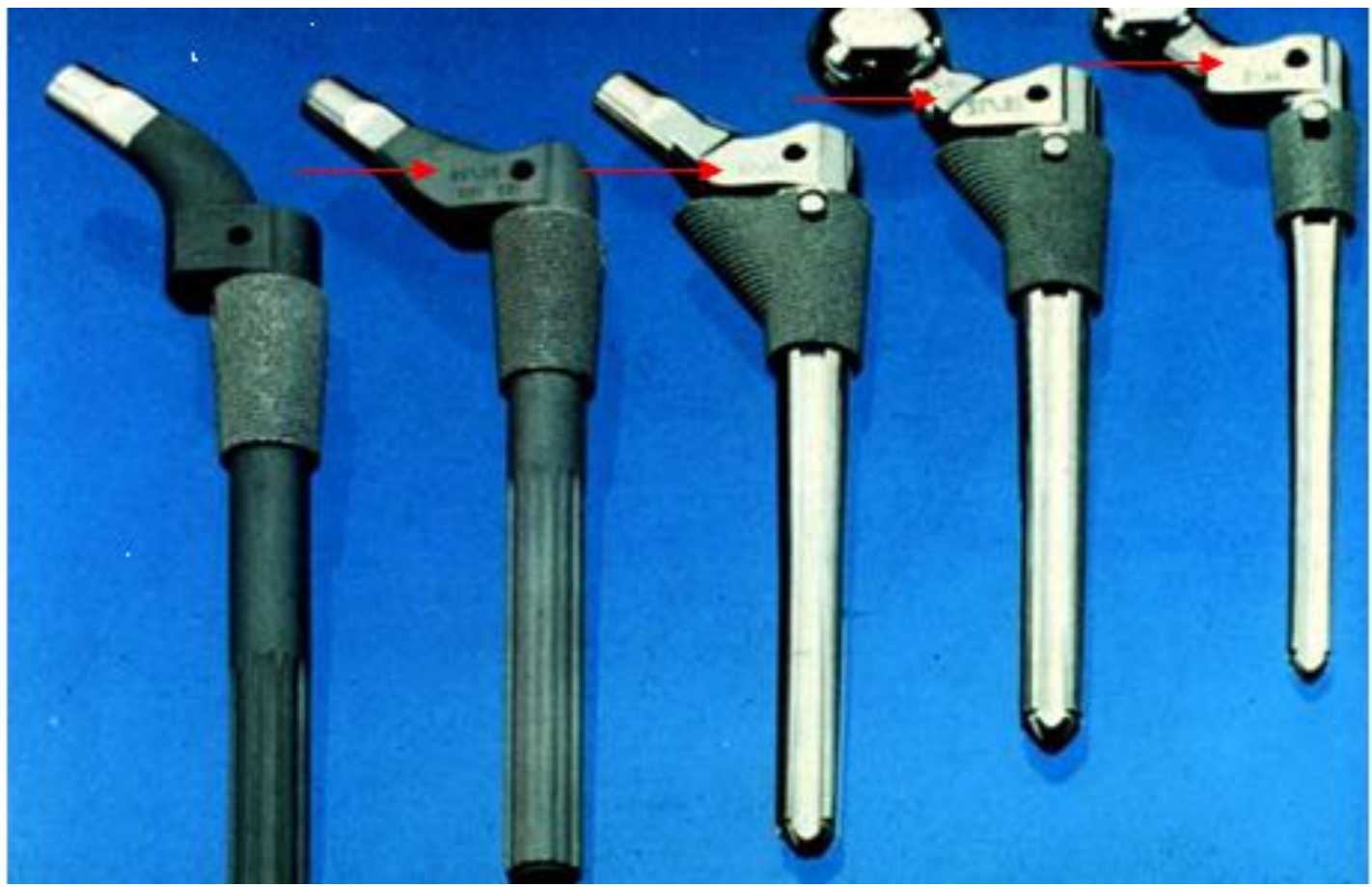

Figura 3. 2. Implantes ortopédicos femorais, metálicos, com marcações.

Para minimizar potenciais efeitos adversos, como redução das propriedades mecânicas ou de resistência à corrosão, é preciso empregar técnicas de marcação apropriadas e escolher uma posição adequada para a marcação do implante.

Segundo a norma ABNT NBR 12932:2010 [10], a localização da marcação em implantes deve ser em uma região de baixa concentração de tensão e não deve cruzar as bordas de furos, escareamentos ou bordas de implantes e, indicada no projeto do implante. Podem ser efetuadas por várias técnicas, mas para efeito de estudo, o presente trabalho se restringiu a analisar as técnicas de marcação via laser e mecânica, comparando-as com amostras do material sem marcações.

\subsection{Corrosão}

A corrosão é a reação de um material com o ambiente em que está inserido. A corrosão é um fenômeno que pode ser de natureza química ou de natureza eletroquímica, ou seja, é um processo que envolve tanto reações de oxidação como de redução. [11] 
As formas de corrosão podem ser separadas em dois tipos: localizada e generalizada. Quando pilhas de corrosão separadas podem ser distinguidas pela variação do potencial sobre a superfície metálica, ou pelo aparecimento de correntes de corrosão ou de produtos de corrosão separados, anódicos e catódicos, tem-se a corrosão eletroquímica localizada. No caso oposto, a corrosão é do tipo generalizada. Muitos metais e ligas metálicas apresentam uma fina película que fornece proteção contra a corrosão. Esta é formada pela reação da superfície do metal com o meio ambiente e é responsável pelo fenômeno da passivação. No caso de aços inoxidáveis, cromo e níquel são usados como elementos de liga já que são facilmente passivados. Em teores de cromo entre $12 \%$ e $18 \%$, as propriedades do $\mathrm{Cr}$ são incorporadas ao aço e, o valor do potencial de passivação varia daquele típico do ferro para aproximadamente o do cromo, aumentando a resistência à corrosão.

\subsubsection{Mecanismos de corrosão - corrosão por pite}

A falha na película passiva, muitas vezes de forma localizada, resulta em ataque ou corrosão localizada que pode ocorrer na forma de pites, corrosão intergranular, corrosão sob tensão e corrosão associada à fadiga.

A corrosão por pite é um ataque localizado, na grande maioria das vezes sobre uma superfície recoberta com óxido. Um pite é iniciado pela adsorção de ânions ativadores, particularmente, íons cloreto. Quando o potencial de pite é atingido, a força do campo elétrico nas partes mais finas do filme será tão alta que os íons cloreto podem penetrar no filme, iniciando a dissolução localizada do filme óxido. Assim, tão logo um pite tenha se formado, este continuará a crescer autocataliticamente.

O mecanismo de corrosão por pite se dá por nucleação e crescimento do mesmo, o qual cria condições para a sua propagação, que são: o enriquecimento de íons cloreto no pite, geração de uma solução ácida dentro do pite; pela hidrólise de íons metálicos; alta condutividade da solução de sal; pelo suprimento limitado de oxigênio e; na parte externa do pite, a formação de uma camada de hidrato, contra-atacando a diluição da solução do pite por difusão e convecção. 
Embora todos os biomateriais metálicos atualmente utilizados tenham suas propriedades de corrosão bem caracterizadas, muitos processos de fabricação de dispositivos podem alterar a resistência à corrosão dos produtos acabados. Ademais, dispositivos com formatos complexos, com cantos, recessos e outras irregularidades de projeto, podem ter sua resistência à corrosão localizada afetada.

Williams [2] comenta sobre o efeito da corrosão de implantes no corpo humano e propõe que se deve distinguir entre três tipos de corrosão: 1) baixa difusão metálica através da camada de óxido para o meio; 2) pouca corrosão observável; 3) corrosão extensiva a toda a área do implante. Nos dois primeiros casos há alguma interação com os tecidos adjacentes ao implante, o que geralmente não implica em efeitos clínicos significativos. O efeito de ataque localizado para o material é mais grave quanto à sua resistência mecânica, podendo levar a falhas por fraturas; já no terceiro caso há uma influência direta no paciente.

\subsection{Características do filme passivo em aços inoxidáveis}

\subsubsection{Composição do filme passivo em aços inoxidáveis}

Conforme o modelo de dupla camada, os filmes passivos são formados por uma camada interna de óxido e uma camada externa de hidróxido ou oxihidróxido. A camada externa age como um local de troca, devido aos íons de valência, já a camada mais interna atua como uma barreira impedindo a corrosão. A estrutura e a espessura das camadas de óxido dependem de fatores como o potencial e o pH do eletrólito.

De acordo com Marcus [12] a composição química, valência, espessura, cristalinidade, rugosidade e presença de defeitos influenciam o crescimento, estabilidade e quebra de camadas finas do filme passivo.

Hakiki et al. [13] estudaram estruturas dos filmes de óxidos formados sobre aços inoxidáveis em solução tampão de borato e, concluíram que estas são formadas por óxidos, espinélios, hidróxidos e geralmente têm a superfície parcialmente hidratada. Com a utilização de técnicas de análise por 
Espectroscopia de Elétrons Auger (AES) e Microscopia de Força Atômica (AFM), descreveram este tipo de óxido como sendo composto por uma região interna rica em óxido de cromo $\left(\mathrm{Cr}_{2} \mathrm{O}_{3}\right)$, situada próximo ao substrato metálico e, uma região externa, rica em óxido de ferro $\left(\mathrm{Fe}_{2} \mathrm{O}_{3}\right)$ e hidróxido de ferro, estando situada na região da interface do filme - eletrólito, confirmando a característica dúplex do filme de óxido.

Um dos primeiros trabalhos a utilizar a técnica de espectroscopia de fotoelétrons excitados por raios-X (XPS), capaz de fornecer informações da região de interface, foi publicado por Castle e Clayton [14]. Utilizando para estudo um aço inoxidável austenítico com $18 \%$ de cromo e $8 \%$ de níquel e, repassivando-se em água desaerada, à temperatura ambiente; observou-se o caráter dúplex da camada passiva e foi possível determinar que a região mais interna da camada era enriquecida em cromo e, a mais externa em íons hidroxila.

\subsubsection{Propriedades eletrônicas do filme passivo em aços inoxidáveis}

O filme passivo apresenta o comportamento de um semicondutor, logo suas propriedades podem ser avaliadas através de suas estruturas eletrônicas. $O$ movimento de elétrons através do material em suas bandas de energia determina a sua condutividade. Segundo Callister [15], as bandas de energia são divididas em: bandas de valência, que é o nível de energia mais alto ocupado por elétrons e, banda de condução, que trata-se do nível de energia mais baixo desocupado. Os metais apresentam a banda de condução seguida da banda de valência, ou seja, não há uma separação oriunda de diferença de energia entre essas bandas; desta forma, os elétrons podem ocupar a banda de condução, por isso são conhecidos como materiais condutores. Os materiais que possuem uma diferença de energia entre a banda de valência e a banda de condução são conhecidos como semicondutores e isolantes.

O "band gap", nome dado a esta diferença de energia é grande (superior a $3 \mathrm{eV}$ ) nos isolantes e, para os semicondutores, um valor intermediário (da ordem de zero a $3 \mathrm{eV}$ ), possibilitando o deslocamento de elétrons para as bandas de mais baixas energias desocupadas. 
Quando um elétron é excitado e migra de um nível de energia para outro, este deixa uma vacância ou lacuna, que é carregada positivamente. Estas podem ser movidas pelo espaço através da ocupação das vacâncias por elétrons.

Os semicondutores podem ser classificados como extrínsecos, isto é, dopados e, intrínsecos, ou seja, não dopados [15]. Os semicondutores extrínsecos podem ser do tipo-p ou do tipo-n, quando o transporte de carga é efetuado por vacâncias ou, quando o transporte de carga é realizado por elétrons, respectivamente.

Vários artigos [15-20] foram publicados nos últimos anos, onde o comportamento semicondutor de filmes passivos em aços inoxidáveis fora investigado, relacionando suas propriedades eletrônicas com a resistência à corrosão.

O modelo de camada dupla de óxidos formados sobre aços inoxidáveis austeníticos [13] propõe o comportamento de um semicondutor tipo-n na camada externa, ou seja, próxima à solução e o comportamento de um semicondutor tipop na camada mais interna, rica em óxido de cromo, mais próxima ao substrato. $\mathrm{O}$ processo de difusão através do filme passivo é apresentado na Figura 3.3.

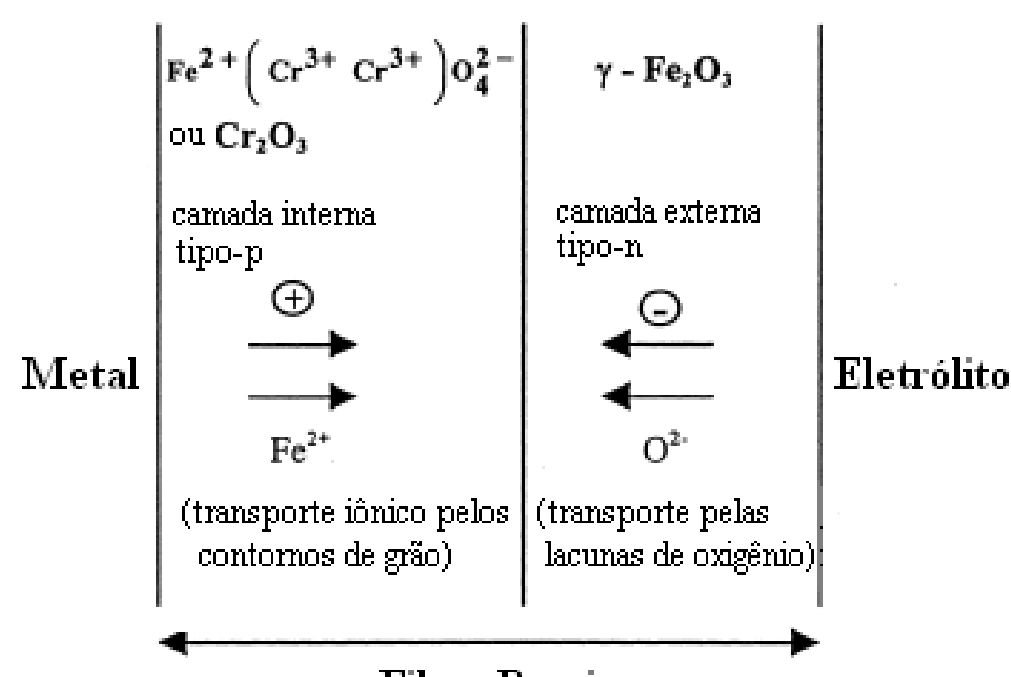

Filme Passivo

Figura 3.3. Representação esquemática do processo de difusão através da camada dúplex do filme passivo. (Figura adaptada da referência [16]). 
Atualmente a abordagem mais empregada para se estudar as propriedades eletrônicas dos filmes passivos é a de Mott-Schottky; através da qual são realizadas medidas de capacitância, utilizando-se espectroscopia de impedância eletroquímica, em uma freqüência específica. Os resultados deste método são apresentados em gráficos de medidas do inverso do quadrado das capacitâncias em função do potencial. As inclinações dos gráficos de Mott-Schottky são associadas com os semicondutores presentes nos óxidos, ou seja, inclinação positiva relacionada a um semicondutor tipo-n e, inclinação negativa relacionada a um semicondutor tipo-p. A equação (1) é a expressão de Mott-Schottky, usada para descrever a interface filme passivo-eletrólito para um semicondutor tipo-p.

$$
\frac{1}{C^{2}}=\frac{1}{C_{H}^{2}}+\frac{2}{\varepsilon \varepsilon_{o} q N q}\left(-E+E b p+\frac{k T}{e}\right)
$$

(equação 1)

onde C é a capacitância da interface filme passivo-eletrólito, $\mathrm{C}_{\mathrm{H}}$ é a capacitância da camada de Helmholtz, E é o potencial aplicado, $\varepsilon$ é a constante dielétrica da película passiva, $\varepsilon_{0}$ é a permissividade do vácuo, $N_{q}$ é a densidade de doadores ou aceitadores para a dopagem de um semicondutor do tipo-n ou do tipo-p, respectivamente, q é a carga elementar, $\mathrm{k}$ é a constante de Boltzmann, T é a temperatura absoluta e $E_{b p}$ é o potencial de banda plana. O potencial de banda plana, onde não existe excesso de cargas em um semicondutor, pode ser obtido, no gráfico, pela extrapolação de $1 / \mathrm{C}^{2}$ para zero. A concentração de dopantes $\mathrm{N}_{\mathrm{q}}$ é obtida pelas inclinações das curvas [15-20].

A capacidade de transferência de cargas em um semicondutor depende da existência de regiões de depleção ou de acumulação. A região de depleção é caracterizada por sua deficiência de elétrons e ocorre em potenciais positivos a partir do potencial de banda plana $\left(E_{b p}\right)$ para um semicondutor tipo-n e em potenciais negativos a partir de $\left(E_{b p}\right)$ para um semicondutor tipo-p. A região de acumulação, caracterizada por um excesso de elétrons, ocorre em potenciais mais negativos a partir de $\left(E_{b p}\right)$ para semicondutores tipo-n e mais positivos a 
partir de $\left(E_{b p}\right)$ para semicondutores do tipo-p. As representações dos gráficos de Mott-Schottky sempre se dão nas formas das regiões de depleção [15-20].

Conforme Hakiki et al. [19], a presença de inclinações em sentidos opostos nos gráficos de $1 / C^{2}$ versus $E$, mostra que em modo contrastante com o modelo de heterojunção clássica, as regiões de carga espacial formadas sobre o óxido, se comportam de acordo com o potencial como regiões de acumulação ou de depleção. Desta forma, o óxido protetor age como uma barreira Schottky antes e após o potencial de banda plana. Estes pesquisadores propuseram um modelo esquemático, que está apresentado na Figura 3.4, para representar a estrutura eletrônica dos óxidos formados em aços inoxidáveis e em ligas de Fe-Cr. Neste esquema o mesmo valor de "band-gap" é apresentado para os óxidos de cromo e de ferro, onde segundo referências utilizadas pelos autores e resultados obtidos pelos mesmos, confirmaram, por medidas fotoeletroquímicas, que o "band-gap" para o óxido de ferro apresenta valor aproximadamente igual a $2 \mathrm{eV}$, mas para o óxido de cromo, este não é bem estabelecido. O intuito deste modelo é mostrar que o óxido de cromo age como uma barreira Schottky numa faixa ou extensão de potencial onde o óxido de ferro se comporta como um contato ôhmico (condutor) e vice-versa.

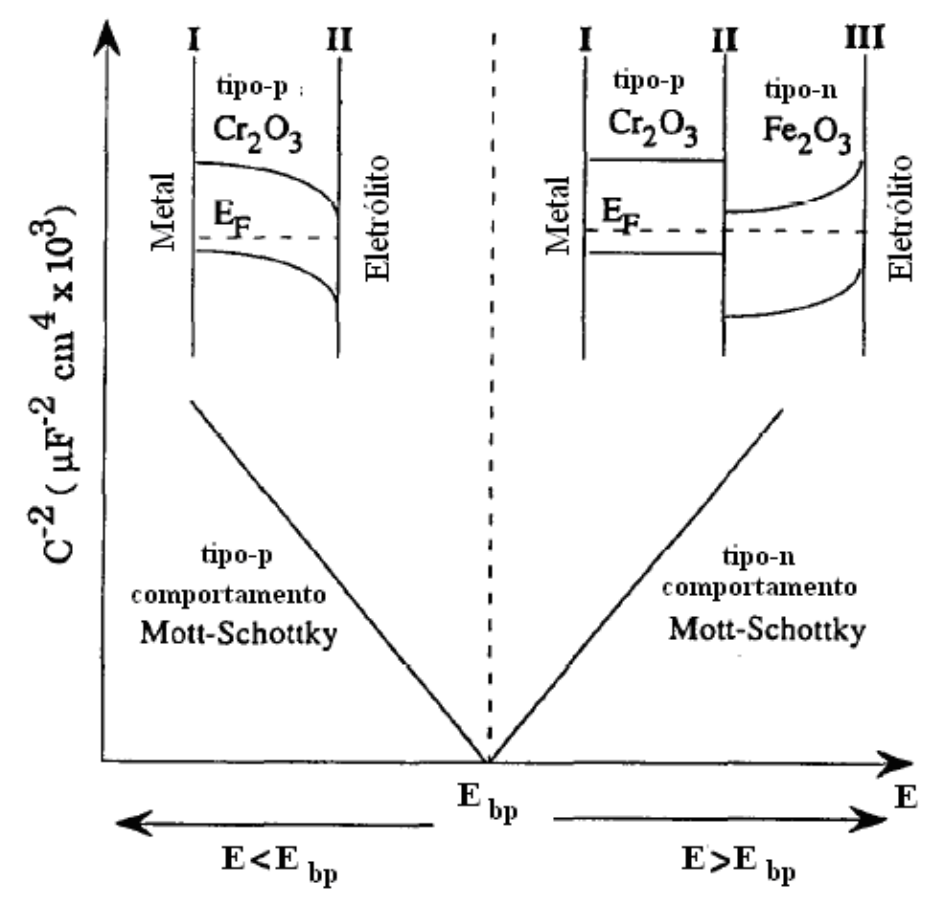

Figura 3.4. Representação esquemática da estrutura eletrônica dos óxidos formados em aços inoxidáveis e em ligas de $\mathrm{Fe}-\mathrm{Cr}$, através da abordagem de Mott-Schottky; onde $\mathrm{E}_{\mathrm{F}}$ é o nível de Energia de Fermi. (Adaptado da referência [19]). 
$\mathrm{Na}$ interface filme passivo- eletrólito há um acúmulo de elétrons. Esta interface se comporta como um contato ôhmico e, se a polarização for elevada, ocorre a degeneração das propriedades semicondutoras da região do óxido de ferro. [19]

Montemor et al. [21] estudaram a estrutura eletrônica e a composição química de filmes passivos formados sobre o aço inoxidável 316L e ligas de níquel (Alloy 600 e Alloy 690), em ambientes aquosos a alta temperatura. A estrutura eletrônica do óxido foi analisada pela abordagem de Mott-Schottky e a composição química por espectroscopia de elétrons Auger (AES). O óxido protetor foi formado sobre estas ligas em solução de $\mathrm{NaOH}$ e $\mathrm{H}_{2} \mathrm{SO}_{4} \mathrm{com}$ pH 8 e $\mathrm{pH} 10$. Os resultados extraídos dos gráficos de Mott-Schottky apresentaram o comportamento de um semicondutor tipo-p associado à camada mais interna (região mais rica em cromo) e, de um semicondutor tipo-n associado à camada mais externa do óxido, composta por óxidos de ferro.

O trabalho publicado por Toor [22] utiliza a abordagem de Mott-Schottky para analisar o filme passivo em aços inoxidáveis contendo silício como elemento de liga, o que eleva a sua resistência à corrosão por pite. Baseado em análises de espectroscopia de elétrons Auger (AES), garante-se que a parte mais interna do filme passivo é composta por $\mathrm{Cr}_{2} \mathrm{O}_{3}$ e a mais externa por $\mathrm{SiO}_{2}$. Para o cálculo do número de defeitos, foi analisado o filme formado por nove horas, à temperatura ambiente e em solução tamponada de borato de $\mathrm{pH} 8,5$, à $0,4 \mathrm{~V}_{\mathrm{ECS}}$ e $0,8 \mathrm{~V}_{\mathrm{ECS}}$. $\mathrm{A}$ frequência utilizada foi de $1 \mathrm{kHz}$. Segundo o autor, o número de defeitos $N_{D}$ (doadores) e $N_{A}$ (aceitadores ou recebedores) é inversamente proporcional às inclinações das curvas que representam os semicondutores tipo-n e tipo-p, respectivamente.

Em vários trabalhos [18,22-25], para efeito de cálculo de número de defeitos, costuma-se desprezar a capacitância da camada de Helmholtz $\left(\mathrm{C}_{\mathrm{H}}\right)$, utilizando-se as equações: (2) para um semicondutor tipo-n e, (3) para um semicondutor tipo-p.

$$
\frac{1}{C^{2}}=\frac{2}{\varepsilon \varepsilon_{0} e N_{D}}\left(E-E_{b p}-\frac{k T}{e}\right)
$$




$$
\frac{1}{C^{2}}=-\frac{2}{\varepsilon \varepsilon_{0} e N_{A}}\left(E-E_{\boldsymbol{b p}}+\frac{k T}{e}\right)
$$

(equação 3)

O potencial de banda plana $\left(E_{b p}\right)$ representa uma região onde é estabelecida uma transição entre os defeitos eletrônicos dos dois tipos de semicondutividade $\mathrm{n}$ e $\mathrm{p}$. Neste potencial é determinada a posição das bandas de energia, no tocante aos potenciais redox dos ions eletro-ativos no eletrólito. A partir do potencial de banda plana, uma inclinação positiva está relacionada a um semicondutor tipo-n e, uma inclinação negativa, com um semicondutor tipo-p. Consequentemente, o filme passivo atua como uma barreira Schottky antes e após o potencial de banda plana.

Toor [22] afirma que as propriedades semicondutoras dos filmes passivos estão intimamente relacionadas à sua estrutura físico-química, isto é, suas propriedades anti-corrosivas.

\subsection{Espectroscopia de Impedância Eletroquímica (EIE) com Modelamento via Circuitos Elétricos Equivalentes (CEE)}

Para se representar as características físicas e elétricas da camada passiva são utilizados os resultados obtidos empregando-se a técnica de espectroscopia de impedância eletroquímica (EIE), os quais podem ser modelados e interpretados via circuitos elétricos equivalentes (CEE). Os modelos de circuitos elétricos equivalentes comumente utilizados e descritos na literatura [26], se valem de uma combinação de capacitores, resistores, elementos de fase constante (CPEs) ou elementos de Warburg, arranjados em série e/ou em paralelo. De acordo com Bonora et al.[26], o circuito deve ser representado da forma mais simples possível, isto é, deve conter o menor número de componentes possíveis dentro de um limite de tolerância (erro aceitável), ou seja, se mesmo retirando-se um elemento do sistema a condição previamente definida ainda prevalecer, o circuito deve ser simplificado. Outra condição referida pelo autor é que cada unidade (elemento) do circuito elétrico deve possuir um significado físico claro, associado às propriedades que podem gerar este tipo de resposta elétrica. 
Ao se avaliar um sistema eletroquímico real por EIE, prefere-se um elemento de fase constante (CPE) a um capacitor ideal, haja vista a não idealidade de um sistema eletroquímico real. $A$ impedância deste elemento $\left(Z_{\mathrm{CPE}}\right)$ é calculada pela seguinte equação (4):

$$
Z_{\mathrm{CPE}}=\left(\frac{1}{\mathrm{Y}_{\circ}}\right)(j \omega)^{-n} \quad \text { (equação 4) }
$$

Onde $Y_{0}$ e $n$ são constantes do CPE e, representam as características superficiais das espécies eletroativas independentes e a distribuição não-uniforme da corrente elétrica, devido à rugosidade e imperfeições superficiais, respectivamente [27] e, j = $\sqrt{ }-1$ e $\omega$ é a freqüência angular. Segundo Liu et al. [28], o valor de $n$ situa-se entre 0 e 1. Quando $n=0$, o CPE é um resistor puro e, quando $\mathrm{n}=1, \mathrm{Y}_{\mathrm{o}}=\mathrm{C}$, o CPE é representado por um capacitor real.

Existe um grande leque de modelos de CEEs propostos para modelar o comportamento eletroquímico de filmes passivos, como os formados sobre os aços inoxidáveis [29-33].

A técnica de espectroscopia de impedância eletroquímica apoiada por modelamentos de circuitos elétricos equivalentes é muito utilizada com o objetivo de investigar os fenômenos de corrosão em ligas metálicas [34-35], principalmente nas ligas utilizadas como biomateriais, em soluções que simulam os fluidos corpóreos com os mais diversos pHs; algumas condições não se assemelham às avaliadas neste trabalho.

\subsection{Técnica Eletroquímica Localizada - SVET}

Diante da complexidade dos materiais a serem analisados, seja pela qualidade do acabamento superficial das amostras, diferentes formatos $e$ dimensões, ou pelo que se deseja investigar; os equipamentos e as técnicas clássicas disponíveis tornam-se incapazes de fornecer as respostas requeridas. A necessidade de se obter informações específicas detalhadamente proporcionou a 
pesquisa e o desenvolvimento de novas tecnologias a fim de preencher esta lacuna.

No campo dos ensaios de eletroquímica e corrosão surgiram as técnicas localizadas, que são técnicas mais sensíveis e que proporcionam alta resolução por possuírem sistema de captura de imagem via microscópio óptico acoplado aos aparatos eletroquímicos. Os mais conhecidos são 0 microscópio eletroquímico de varredura (SECM) e o microscópio de varredura de tunelamento (STM). Entre parênteses está a sigla em inglês, que é utilizada para se referir tanto ao equipamento quanto à técnica.

Outra técnica que vem aumentando o seu campo de atuação é a chamada Técnica de Varredura com Eletrodo Vibrante, cuja sigla em inglês é SVET; e também foi utilizada neste trabalho a fim de apoiar os dados obtidos pelas técnicas clássicas e possibilitar uma nova maneira de extrair e representar resultados bem como consolidar suas discussões, por se tratar de uma técnica eletroquímica localizada.

Estas técnicas eletroquímicas localizadas permitem que o pesquisador selecione a região que será analisada, através do microscópio, e que execute ensaios localizados de potencial de corrosão em circuito aberto, impedância eletroquímica localizada, polarizações e voltametrias cíclicas localizadas.

Os ensaios podem ser realizados em células com micro-eletrodos, ultramicro-eletrodos ou até com nano-eletrodos, nas mais diversas condições: tamanhos de células, períodos de ensaio, meios químicos e metodologias [36-44]. Outras informações encontram-se com maiores detalhes na seção de Materiais e Métodos.

\subsection{Acabamento Superficial}

O processo de confecção de um dispositivo médico implantável como, por exemplo, um implante ortopédico que substitua uma articulação móvel do corpo ou, uma prótese dentária requer segurança biomédica e mecânica bem como biocompatibilidade. Para resguardar a integridade do dispositivo, bem como dos tecidos e órgão adjacentes ao mesmo, garantindo assim melhor qualidade de vida aos pacientes, é necessário que as propriedades mecânicas não se alterem ao 
longo de sua vida útil, ou pelo menos, que permaneçam estáveis durante um prolongado período de uso. Entre os biomateriais metálicos, os mais utilizados são: titânio puro, ligas de titânio, ligas de cobalto e aços inoxidáveis; estes últimos são os mais baratos e, mais utilizados em cirurgias cobertas pelo Sistema Único de Saúde (SUS). Os elementos químicos : Ti, Zr, Nb e Ta são os mais biocompatíveis [45]. O elemento $V$ é classificado como tóxico, e o $\mathrm{Zr}$ e o Ti são os elementos que auxiliam o crescimento dos osteoblastos e a osseointegração.

O acabamento superficial destes dispositivos é fundamentalmente importante porque assegura que o mesmo vai desempenhar suas funções adequadamente; por exemplo, um biomaterial metálico que será cimentado dentro de um osso necessita de um acabamento superficial mais áspero, por outro lado, às vezes o mesmo biomaterial precisa de uma região com acabamento mais liso.

De modo geral, a rugosidade é requerida para que haja maior aderência e fixação, já o acabamento mais fino, liso e polido é desejado para articulações móveis do corpo; estas normalmente são substituídas por conjuntos contendo biomateriais metálicos e poliméricos ou, metálicos e cerâmicos, ou ainda, metálicos e compósitos. Para aumentar a rugosidade da superfície, geralmente, esta é lixada ou jateada, muitas vezes com micro-esferas de vidro.

As características do acabamento superficial influenciam vários fatores relacionados às propriedades dos biomateriais, entre elas a dureza, o desgaste, o atrito [46] e, a resistência à corrosão. Por fim é realizada a marcação, que é objeto de estudo deste trabalho, com a finalidade de identificação do dispositivo médico, de acordo com as normas vigentes [10]. 


\section{MATERIAIS E MÉTODOS}

\subsection{Material}

O material utilizado neste trabalho foi o aço inoxidável austenítico ABNT NBR ISO 5832-1. Os corpos-de-prova foram confeccionados no formato de chapas laminadas com as dimensões: $17 \mathrm{~mm} \times 72 \mathrm{~mm} \times 1,5 \mathrm{~mm}$, de composição química normatizada apresentada anteriormente na Tabela 3.1. Foi realizada análise da composição química utilizando-se o método de espectroscopia de emissão óptica que será apresentada posteriormente na seção de resultados. As amostras, fornecidas pelo Instituto de Ortopedia e Traumatologia do Hospital das Clínicas da Faculdade de Medicina da Universidade de São Paulo (IOTHCFMUSP), foram produzidas pela empresa Baumer Ltda.

\subsection{Marcações}

As amostras sofreram marcações por técnica mecânica e via raios laser. Para efeito de comparação, também foram analisadas amostras do referido aço sem marcações. O processo de marcação consistiu na gravação de algarismos oito, de modo a cobrir a maior área superficial possível, deixando livres de marcações as bordas das chapas, a fim de possibilitar a análise da área adjacente à gravação, como é apresentado na Figura 4.1. A marcação é comumente utilizada como identificação futura ou rastreabilidade do implante para possibilitar a análise das condições do dispositivo médico implantável, após um dado período de uso (anos) ou, em decorrência de alguma falha prematura (fratura).

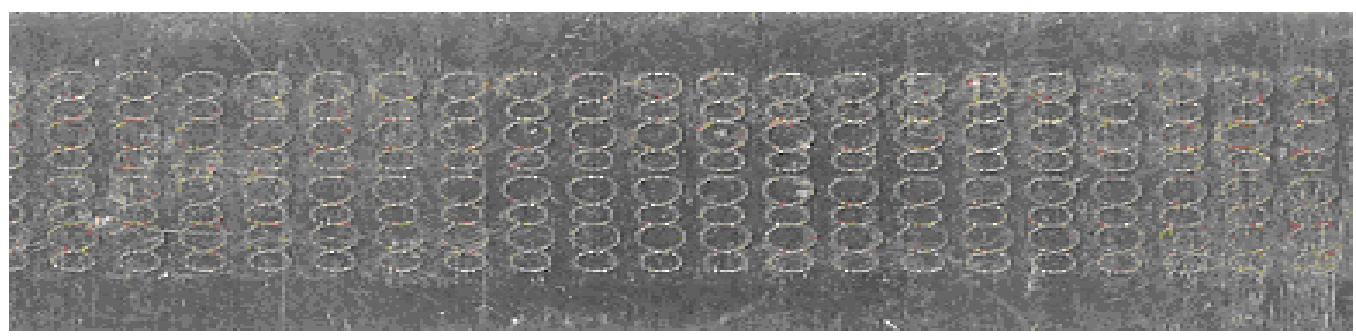

Figura 4.1. Amostra laminada do aço utilizado neste trabalho, marcada pela técnica de raios laser. 


\subsection{Análises Microestruturais}

As análises microestruturais do aço, antes e após os ensaios eletroquímicos, foram obtidas via:

\subsubsection{Microscopia Óptica (MO)}

As análises por microscopia óptica foram realizadas em um microscópio óptico da marca Leica, disponível no laboratório de corrosão e ensaios acelerados Labcorts do IPEN. As amostras foram observadas nas condições: como recebida e após os ensaios eletroquímicos, sem ataque metalográfico e com ataque.

Os ataques metalográficos utilizados foram por imersão em água régia, imersão em reagentes Marble e Vilela e, ataque eletrolítico em solução aquosa de ácido oxálico, $10 \% \mathrm{v}$ durante um minuto (segundo procedimento $13 \mathrm{~b}$ da norma ASTM E407-99).

Obtiveram-se imagens tanto de topo, quanto de vista lateral (amostras cortadas e embutidas em resina epóxi).

A microscopia óptica também foi utilizada para se determinar algumas dimensões das gravações a laser, tais como: comprimento e largura da gravação e, altura e profundidade da gravação em relação ao substrato metálico, como está apresentado na seção de resultados.

\subsubsection{Microscopia Eletrônica de Varredura (MEV)}

Um microscópio eletrônico de varredura Philips XL30 com microssonda EDAX para análise espectrométrica de raios- $X$, do Departamento de Engenharia Metalúrgica e de Materiais da Escola Politécnica da Universidade de São Paulo (PMT-EPUSP) foi utilizado para se observar a microestrutura das amostras do aço inoxidável austenítico ABNT NBR ISO 5832-1, antes e após os ensaios eletroquímicos, com e sem ataque; que serão comentados na apresentação dos resultados e discussões. As amostras verificadas possuíam marcações do tipo laser e mecânicas e, para efeito de comparação, amostras sem marcações. 
Analisou-se, também, a composição química de algumas amostras via espectroscopia de energia dispersiva (EDS).

\subsubsection{Microscopia de Alta Resolução (Field Emission Gun)-(SEM-FEG)}

Para se obter melhor resolução de imagens, foi utilizado um microscópio eletrônico de varredura (SEM-FEG) de alta resolução, FEI - INSPECT F50, com canhão de emissão de elétrons por efeito de campo, do Laboratório de Nanotecnologia do Laboratório Nacional de Luz Síncroton (LNNano / LNLS) em Campinas-SP. As análises semiquantitativas de elementos químicos foram realizadas com apoio de sonda e programa EDS QUANTA - INCA Projects.

\subsubsection{Microscopia Eletrônica de Transmissão (MET)}

Utilizou-se um microscópio eletrônico de transmissão JEOL, modelo JSM2100, do Laboratório de Microscopia Eletrônica do IPEN, com apoio dos softwares DIGITAL MICROGRAF e NORAN SYSTEM para as análises semiquantitativas de EDS. As amostras foram cortadas em formato de lâminas muito finas e, depois afinadas eletrolíticamente e novamente cortadas em formato circular (padrão para análise) nas regiões com marcação a laser, sem marcação e, na região interfacial entre marcações.

\subsection{Ensaios Eletroquímicos}

A caracterização da resistência à corrosão do aço estudado com dois tipos de marcações, a laser e mecânica, bem como o material sem marcações, com acabamento superficial de lixamento e polimento foi realizada por métodos eletroquímicos. Os ensaios eletroquímicos foram realizados em um equipamento Gamry PCI4/300, disponível no Labcorts / IPEN, utilizando-se uma célula plana vítrea (flat-cell), apresentada na Figura 4.2, de três eletrodos, consistindo em um eletrodo de trabalho com área exposta para os ensaios de $1,0 \mathrm{~cm}^{2}$, um contra- 
eletrodo de platina platinizada e um eletrodo de referência de $\mathrm{Ag} / \mathrm{AgCl}(3 \mathrm{M})$ e, em um equipamento SVET fabricado pela Applicable Electronics Inc., com câmera de imagens Panasonic e softwares ASET e QUICKGRID do Laboratório de Processos Eletroquímicos e Corrosão da Universidade Federal do Rio Grande do Sul (Eletrocorr / UFRGS) em Porto Alegre - RS, utilizando-se células poliméricas em formato cilíndrico e vedação com adesivo epóxi tipo Araldite. Os ensaios realizados consistiram de:

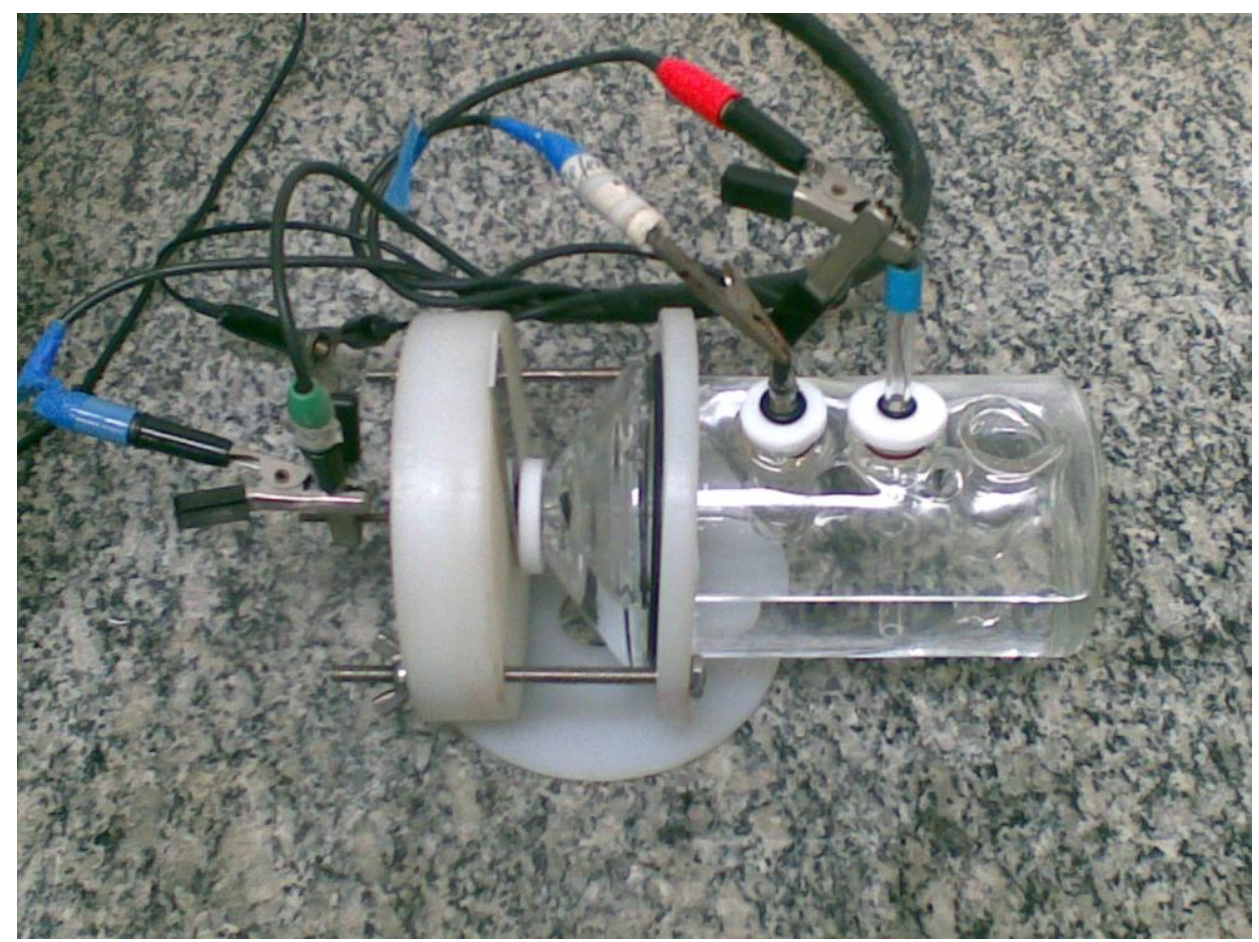

Figura 4.2. Célula plana de três eletrodos utilizada para os ensaios eletroquímicos no Labcorts.

\subsubsection{Potencial de Circuito Aberto (PCA)}

O monitoramento da variação do potencial de corrosão em função do tempo de imersão das amostras sem gravações e com gravações mecânicas e a laser foi acompanhado ao longo de dezessete horas em um solução salina de fosfato tamponada (PBS) de $\mathrm{pH} \mathrm{7,4;} \mathrm{segundo} \mathrm{a} \mathrm{norma} \mathrm{ABNT} \mathrm{NBR} \mathrm{15613-2:2010}$ [47], meio que simula a composição dos fluidos corpóreos, cuja composição química é mostrada na Tabela 4.1, a seguir; naturalmente aerada a temperatura 
de $37^{\circ} \mathrm{C}$. Foram realizados um total de cinquenta ensaios para cada tipo de condição de superfície a fim de se garantir a reprodutibilidade das condições.

Tabela 4.1. Composição química ( $\mathrm{g} / \mathrm{L})$ da solução salina de fosfato tamponada (PBS).

\begin{tabular}{cccc}
\hline $\mathrm{NaCl}$ & $\mathrm{KCl}$ & $\mathrm{Na}_{2} \mathrm{HPO}_{4}$ & $\mathrm{KH}_{2} \mathrm{PO}_{4}$ \\
\hline 8,0 & 0,2 & 1,15 & 0,2 \\
\hline
\end{tabular}

\subsubsection{Espectroscopia de Impedância Eletroquímica (EIE)}

As amostras do aço inoxidável austenítico ABNT NBR ISO 5832-1, sem gravações e com gravações mecânicas e a laser, imersas em solução PBS, descrita anteriormente, na temperatura de $37^{\circ} \mathrm{C}$ foram avaliadas quanto ao seu comportamento eletroquímico. Os espectros de impedância eletroquímica foram gerados após 17 horas de imersão. Todas as medidas de EIE, (cinquenta para cada condição de acabamento de superfície), foram realizadas no potencial de circuito aberto, utilizando-se um sinal de perturbação senoidal com amplitude de $10 \mathrm{mV}$, na faixa de frequências de $100 \mathrm{kHz}$ até $10 \mathrm{mHz}$, taxa de aquisição de dados de 10 pontos por década. Todos os dados foram obtidos por meio de um analisador de respostas em freqüências acoplado a um potenciostato Gamry $\mathrm{PCl} / 300$.

\subsubsection{Polarização Potenciodinâmica Cíclica}

Todos os ensaios de polarização potenciodinâmica cíclica foram conduzidos na mesma solução PBS naturalmente aerada a $37^{\circ} \mathrm{C}$, que corresponde à temperatura corpórea, no mesmo equipamento já mencionados, com eletrodo de referência de $\mathrm{Ag} / \mathrm{AgCl}$ (3M) e contra-eletrodo de platina platinizada. A velocidade de varredura utilizada, na direção anódica, foi de 0,167 $\mathrm{mV} . \mathrm{s}^{-1}$, a partir do potencial de circuito aberto.

Foram avaliados os comportamentos eletroquímicos dos corpos-de-prova (cps) com gravações via raios laser, gravações mecânicas e sem gravação, num 
total de cinquenta ensaios de cada e, obteve-se reprodutibilidade em sua quase totalidade.

O método fora propositalmente concebido para atingir condições que fossem suficientemente severas para causar ruptura da camada passiva dos dispositivos médicos, as quais podem não necessariamente ser encontradas in vivo. De acordo com a norma ABNT NBR 15613-2:2010 [47], os corpos-de-prova (cps) foram preparados de modo que a região exposta à solução de ensaio esteja nas mesmas condições metalúrgicas e de superfície que a forma implantável do dispositivo médico. Segundo a referida norma, a velocidade de varredura pode afetar o potencial de ruptura do dispositivo e a forma da região passiva da curva de polarização.

É oportuno salientar que a grande maioria dos biomateriais em avaliação para a fabricação de implantes não pode ser diferenciada ou selecionada sob o aspecto da corrosão com ensaios de imersão convencionais, por resultar em perda de massa irrisória durante um longo período de pesquisa. Consequentemente, para selecionar materiais em um tempo razoável, os processos de corrosão têm que ser induzidos ou acelerados de alguma maneira.

\subsubsection{Propriedades eletrônicas do filme passivo - Abordagem de Mott- Schottky}

As propriedades eletrônicas do filme passivo formado sobre as amostras do aço inoxidável austenítico ABNT NBR ISO 5832-1, sem gravações e com gravações mecânicas e a laser, imersas em solução PBS, na temperatura de 37ํㅡ foram determinadas por meio da técnica de Mott-Schottky. As medidas de capacitância foram realizadas a $1 \mathrm{kHz}$ de frequência. A polarização foi aplicada a passos sucessivos de $50 \mathrm{mV}(\mathrm{Ag} / \mathrm{AgCl})(3 \mathrm{M})$ na direção catódica a partir de 500 $m V$ até $-1000 m V$. Foram analisadas vinte e cinco amostras de cada condição de acabamento superficial.

Como foi apresentado anteriormente, a abordagem de Mott-Schottky requer o conhecimento de conceitos de semicondutores, como são considerados os óxidos passivos formados nos aços inoxidáveis. Um semicondutor tipo-p é aquele que apresenta um excesso de cargas positivas, já um semicondutor tipo-n 
possui excesso de cargas negativas. O parâmetro definido como potencial de banda plana $\left(E_{b p}\right)$ é o potencial onde não há acúmulo de cargas elétricas no semicondutor; relacionando-se esta condição ao gráfico de Mott-Schottky, corresonde ao valor em que a capacitância é máxima, ou seja, valor de potencial extrapolando-se $1 / \mathrm{C}^{2}$ para zero.

É necessário distingüir que um semicondutor tipo-n apresenta o nível de energia de Fermi próximo à banda de condução, enquanto no tipo-p ele está próximo à banda de valência [15].

A interface óxido / eletrólito para um semicondutor tipo-n pode ser descrita resumidamente pela expressão de Mott-Schottky pela seguinte expressão:

$$
\frac{1}{C^{2}}=\frac{2}{\varepsilon \varepsilon_{0} e N q}\left(E-E_{b p}-\frac{k T}{e}\right)
$$

onde $C$ é a capacitância da interface filme passivo / eletrólito, $E$ é o potencial aplicado, $\varepsilon$ é a constante dielétrica da película passiva e possui valor igual a 12, de acordo com Ahn e Kwon [48], (tanto para o óxido de ferro como para o óxido de cromo), $\varepsilon_{0}=8,85.10^{-14} \mathrm{~F} . \mathrm{cm}^{2}$ é a permissividade do vácuo, $\mathrm{N}_{\mathrm{q}}$ é a densidade de doadores ou aceitadores para a dopagem de um semicondutor do tipo-n ou do tipo-p, respectivamente, $q=1,602.10^{-19} \mathrm{C}$ é a carga elementar, $\mathrm{k}$ é a constante de Boltzmann, $T$ é a temperatura absoluta e $E_{b p}$ é o potencial de banda plana.

Para os aços inoxidáveis, é frequentemente assumido que 0 comportamento semicondutor reflete o caráter duplex de filmes de sua superfície, com uma região interna formada essencialmente de $\mathrm{Cr}_{2} \mathrm{O}_{3}$ e uma região exterior composta principalmente de $\mathrm{Fe}_{2} \mathrm{O}_{3}$. A inclinação positiva revela um comportamento eletroquímico de um semicondutor do tipo-n, que é característica de $\mathrm{Fe}_{2} \mathrm{O}_{3}$; a inclinação negativa é típica de um semicondutor do tipo-p, e está relacionada com a predominância da presença de $\mathrm{Cr}_{2} \mathrm{O}_{3}$. 


\subsubsection{Técnica Eletroquímica de Varredura com Eletrodo Vibrante (SVET)}

Uma das particularidades da corrosão é o fato de os processos anódicos e catódicos ocorrerem em simultâneo e ocuparem regiões diferentes, distribuídas ao longo da superfície do metal.

Por isso, a solução na vizinhança de um metal ativo apresenta variações muito significativas de composição. Não obstante, as técnicas eletroquímicas aplicadas ao estudo da corrosão utilizam, tipicamente, eletrodos com dimensões da ordem dos milímetros ou centímetros, obtendo-se valores médios correspondentes à resposta de toda a amostra [49].

O emprego de microeletrodos permite que os processos corrosivos sejam avaliados na solução, observando-se intimamente a forma como o meio influencia os processos e como estes, por sua vez, modificam o meio.

Svet é a sigla em inglês para Scanning Vibrating Electrode Technique. Com a utilização desta técnica é possível a determinação das áreas onde existem as maiores densidades de correntes de corrosão, evidenciando perfeitamente as zonas anódicas e catódicas. A técnica SVET mede também diferenças de potencial. Numa solução em repouso não há diferenças de potencial significativas, pois a solução está numa situação de eletro-neutralidade. Esta técnica fornece o balanço entre o fluxo de cargas positivas e negativas em cada ponto de medição [49].

Conforme publicado no manual de operação que acompanha o SVET elaborado pelo fabricante, e no "ASET Quick-Start Guide", o guia do programa de computador que controla o sistema desenvolvido pela Science Wares [50], esta é uma técnica eletroquímica não invasiva e não destrutiva que permite conhecer intensidades de corrente locais, em superfícies metálicas ativas imersas num eletrólito; baseia-se na medição das variações de potencial extremamente pequenas, oriundas dos fluxos de correntes iônicas provocadas pelas reações que ocorrem na superfície ativa. 


\subsubsection{Princípio da Técnica}

Numa solução de eletrólito em equilíbrio e sem perturbação exterior, os íons estão homogeneamente distribuídos. Não existem gradientes iônicos, apenas a agitação térmica faz os íons movimentarem-se aleatoriamente na solução. Nesta solução, a diferença de potencial medida entre dois eletrodos nela mergulhados, um imóvel (referência) e o outro movendo-se pela solução (indicador), é apenas a diferença de potencial entre os dois eletrodos, independentemente da posição onde o eletrodo indicador se encontre. No entanto, ao criarem-se condições para que a concentração dos íons varie na solução criam-se gradientes iônicos, associados aos quais se estabelecem gradientes de potencial, ou seja, campos elétricos que forçam o sistema para o equilíbrio. Enquanto essas fontes estiverem ativas haverá locais com diferentes concentrações de íons e correspondentes gradientes de potencial. Neste caso, repetindo-se a medição anterior ao longo da solução, a diferença de potencial entre os dois eletrodos já não é nula e depende do campo elétrico obtido nessa zona, o qual é reflexo da atmosfera iônica aí existente [50].

A SVET consiste precisamente num conjunto de eletrodos, um funcionando como referência e o outro como indicador, e permite fazer este tipo de medições. Para aumentar a resolução espacial da técnica o eletrodo indicador é um microeletrodo (tipicamente com dimensões entre 5-20 $\mu \mathrm{m}$ ).

Um dos problemas iniciais da técnica era a influência do ruído, uma vez que as diferenças de potencial detectadas são tão pequenas que geralmente ficam dissimuladas no ruído. Para sanar este problema o microeletrodo é vibrado por intermédio de um dispositivo piezoeletrônico com uma frequência na ordem dos $100 \mathrm{~Hz}-1000 \mathrm{~Hz}$. O sinal medido em corrente direta, é convertido em corrente alternada com uma frequência igual à da vibração do eletrodo e é analisado num amplificador lock-in que filtra todos os sinais exceto aquele com a frequência de vibração do microeletrodo. Desta forma o ruído é eliminado e a sensibilidade da técnica aumenta grandemente podendo detectar-se variações de intensidades de corrente na ordem dos nano ampéres (nA) [50].

O potencial medido em cada ponto é convertido pela Lei de Ohm em densidade de corrente local após uma calibração prévia do sistema. Esta consiste em colocar o microeletrodo a uma distância conhecida de um outro microeletrodo 
que fornece uma quantidade de corrente conhecida, emergente de um único ponto. Os valores lidos pelo sistema são corrigidos para os novos valores. Estes são válidos enquanto se mantiverem constantes a solução usada, a amplitude e a frequência de vibração e o microeletrodo usado [50].

A equação (6) a seguir relaciona o potencial medido com a corrente iônica e, a Figura 4.3 representa um esquema com as linhas de corrente e linhas de equipotencial que se estabelecem em solução a partir de uma zona anódica no centro de uma área catódica.

$$
V=\frac{I \rho}{2 \pi d}
$$

(equação 6)

Onde: $\mathrm{V}$ é o potencial medido, I é a intensidade de corrente, $\rho$ é a resistividade da solução e, d é a distância da sonda à fonte de corrente.

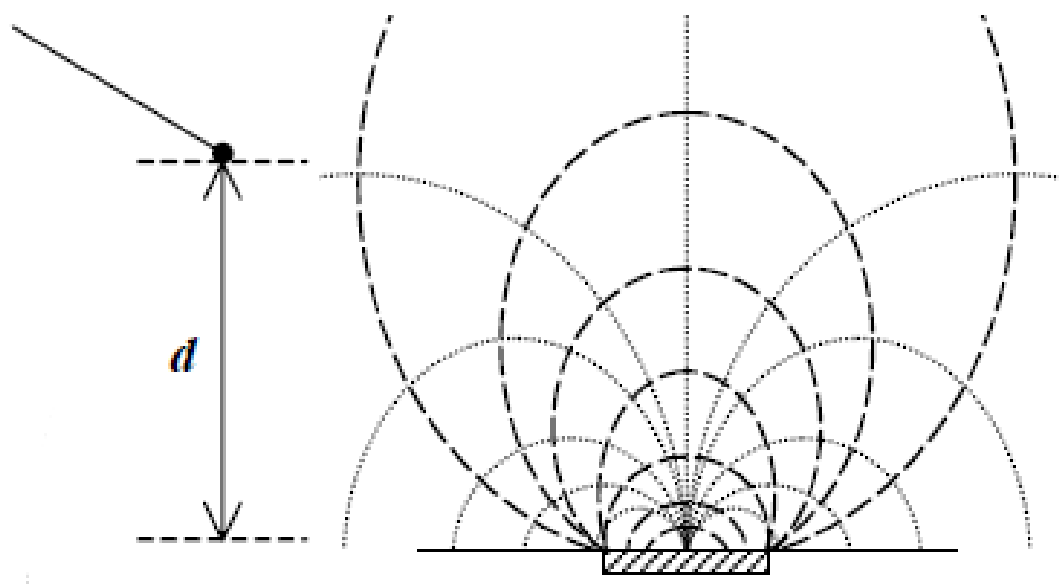

linhas de corrente, - . - - linhas de equipotencial.

Figura 4.3. Representação esquemática de linhas de corrente e de equipotencial numa amostra onde a área anódica encontra-se no centro. (d é a distância da sonda à fonte de corrente). [50] 


\subsubsection{Elementos para aquisição de dados}

Para aquisição de dados são necessários os seguintes equipamentos, representados na Figura 4.4.

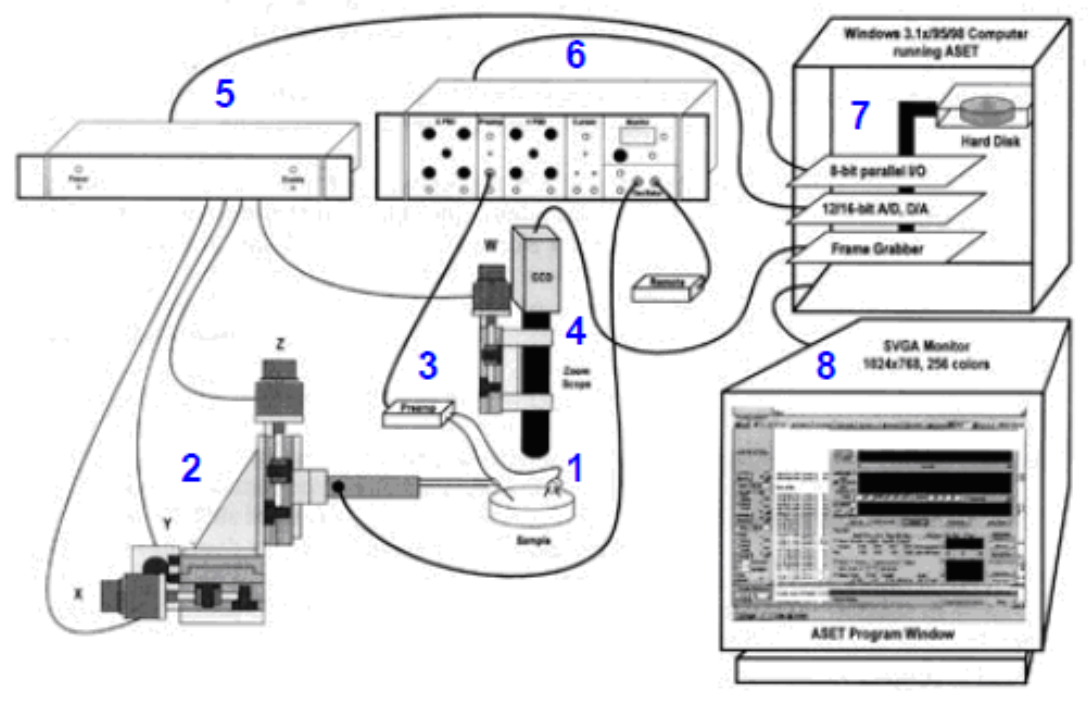

1- célula

2- motores

3- pré-amplificador

4- câmera de vídeo

5- controlador dos motores

6- amplificadores lock-in

7- hardware

8- software ASET

Figura 4.4. Esquema de interação entre os dispositivos do SVET [50].

O sinal em corrente contínua é transformado em corrente alternada devido à vibração do eletrodo. Por isso a frequência do sinal senoidal da corrente é a frequência da vibração. Como o eletrodo vibra em duas direções, $X$ e $Y$, com frequências diferentes, há na realidade dois sinais. Após serem captados pelo eletrodo vibrante (EV) passam pelo pré-amplificador onde são amplificados (10x ou 100x) e daí para o amplificador. Este é composto por dois amplificadores lockin um para cada sinal de vibração, $\mathrm{X}$ e Y. Aí os sinais são filtrados de modo a que só os sinais com fase e frequência da vibração são permitidos, eliminando-se todos os outros sinais, como o ruído, por exemplo. O sinal é amplificado de novo (50x ou 500x). O sistema registra para cada vibração o sinal em fase e em quadratura. Os sinais passam para a placa que existe na CPU onde são processados pelo software, que calcula os valores de corrente usando os valores da calibração existentes. Esses valores são registrados para cada ensaio. [50] 


\subsubsection{Procedimento experimental utilizando-se SVET}

Os procedimentos que devem ser realizados antes de se começar a coleta de medidas são: o teste de capacidade de ponta do eletrodo, teste do amplificador, funcionamento em platinização, preparação de eletrodos, platinização dos mesmos e em seguida, montagem no equipamento, calibração, seleção de frequências e amplitudes de vibração, e posteriormente o tratamento dos resultados com o auxílio dos softwares Aset e QuikGrid.

Especificamente para este trabalho foram analisadas amostras do referido aço inoxidável como recebidas pelo fabricante, nas condições sem marcações e marcadas via raios laser e, também, amostras lixadas até \# 2000 em papel de carbeto de silício e polidas em pasta de diamante até $1 \mu \mathrm{m}$; amostras embutidas em seção transversal e em topo. Foram analisadas após 17 horas de imersão em solução descrita anteriormente.

Antes de iniciarem-se os ensaios houve a necessidade de se medir a condutividade da solução e as profundidades e alturas relativas resultantes da técnica de marcação a laser, já que este procedimento funde o material gerando regiões de "vales" e "picos" onde o material é depositado. As medidas dos picos e dos vales foram obtidas por microscopia óptica. Estas medidas encontram-se apresentadas na seção de resultados. As Figuras 4.5 e 4.6, a seguir, são fotografias do equipamento utilizado para estes ensaios, a Figura 4.7 mostra o microeletrodo vibratório analisando a marcação correspondente ao algarismo oito. 


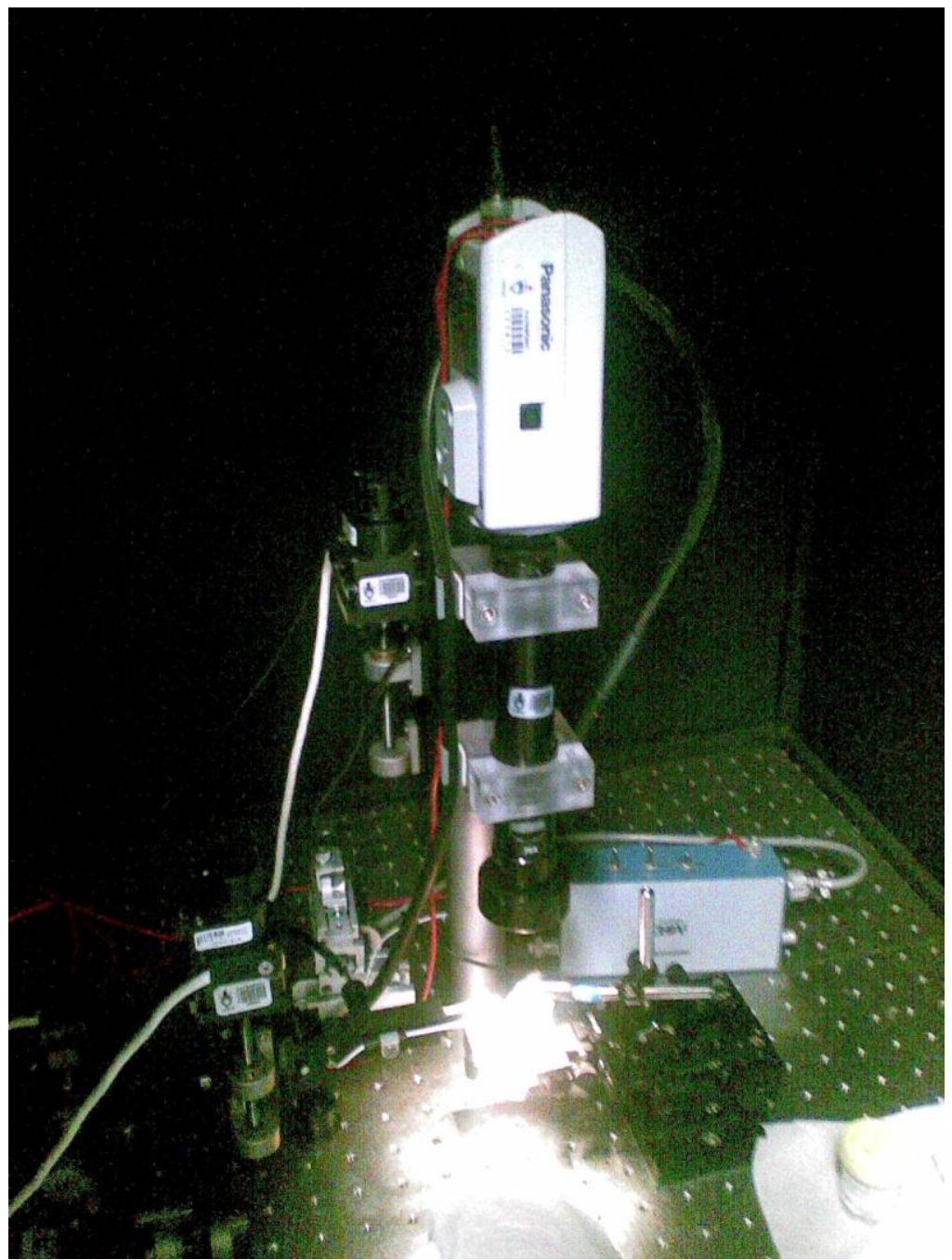

Figura 4.5. Gaiola contendo a célula eletroquímica e o sistema de aquisição de imagens do SVET.

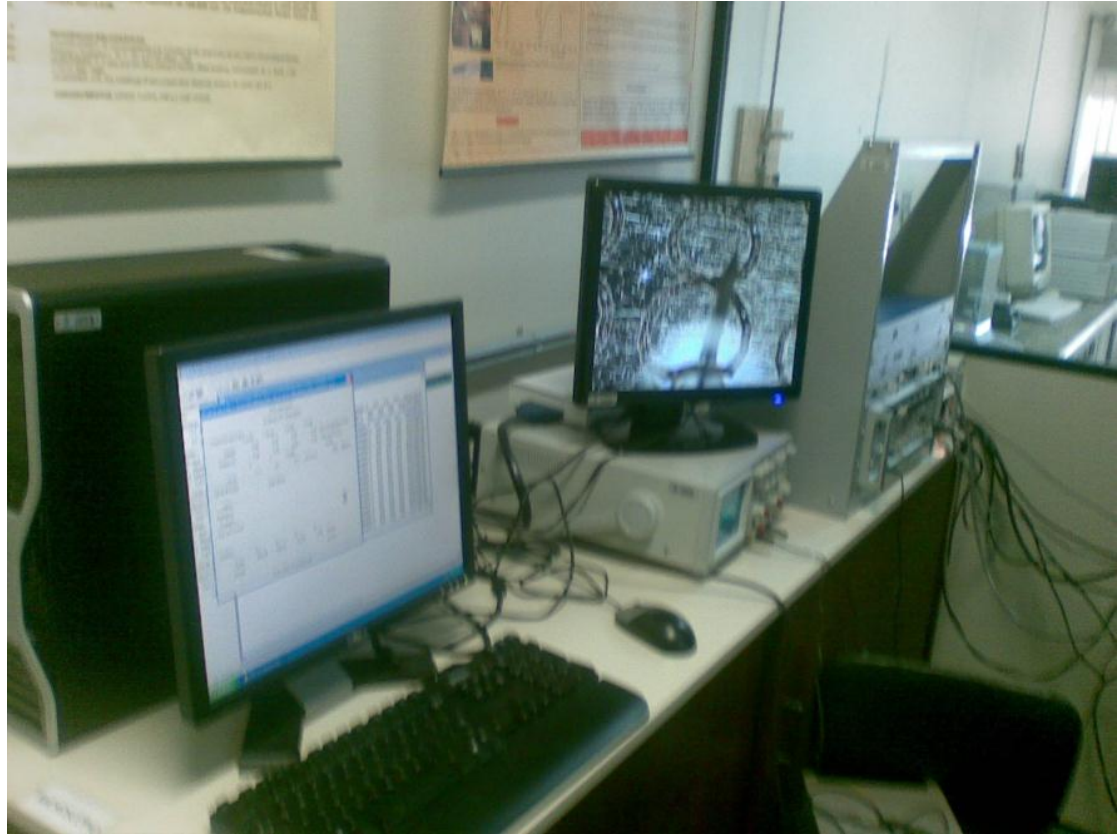

Figura 4.6. Equipamentos utilizados no ensaio SVET. 


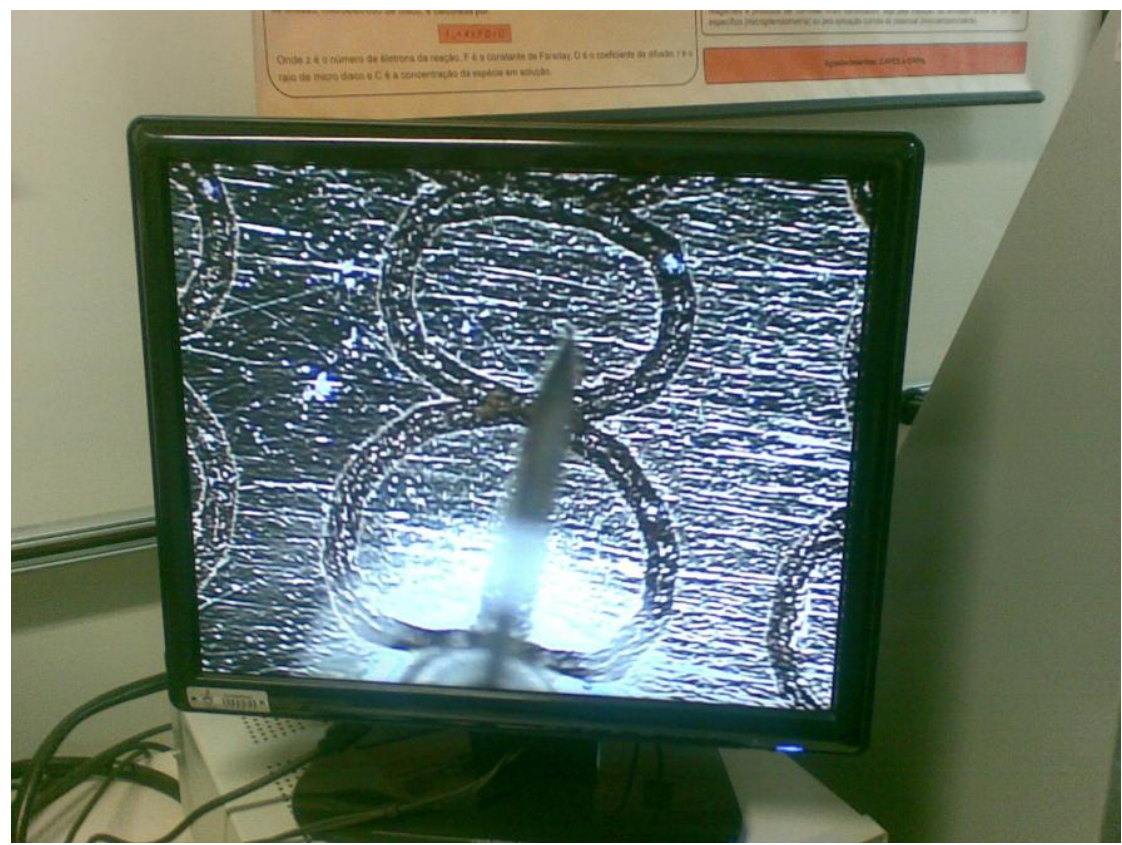

Figura 4.7. Microeletrodo vibrante varrendo região marcada com o algarismo oito.

\subsection{Caracterização de Fase Ferromagnética}

Com o propósito de se caracterizar o aço inoxidável austenítico ABNT NBR ISO 5832-1, quanto à presença de fase ferromagnética, foi utilizado um ferritoscópio do Departamento de Engenharia Metalúrgica e de Materiais da Escola Politécnica da USP. O ensaio consistiu em passar o equipamento sobre a amostra do aço inoxidável nas regiões sem gravações e gravadas a laser, onde houve um passe e dois passes de laser, produzindo o algarismo oito. 


\section{RESULTADOS E DISCUSSÃO}

\subsection{Análises Microestruturais}

Com o propósito de se verificar se a microestrutura do material está adequada para o seu emprego, isto é, como biomaterial, foram realizadas análises microestruturais. Nas Figuras 5.1.1 (a) e (b) estão mostradas microestruturas do aço inoxidável ABNT NBR ISO 5832-1, após ataque eletrolítico em solução aquosa de ácido oxálico $10 \%$ v por 1 minuto. A norma ASTM F-138 estabelece as características microestruturais de aços inoxidáveis austeníticos para aplicações biomédicas, de acordo com esta norma, esta deve ser austenítica e isenta de ferrita delta; o que foi confirmado pelas análises realizadas.

As imagens a seguir apresentam a microestrutura das amostras obtidas por MEV, após ataque eletrolítico em solução aquosa de ácido oxálico 10\%v por 1 minuto.

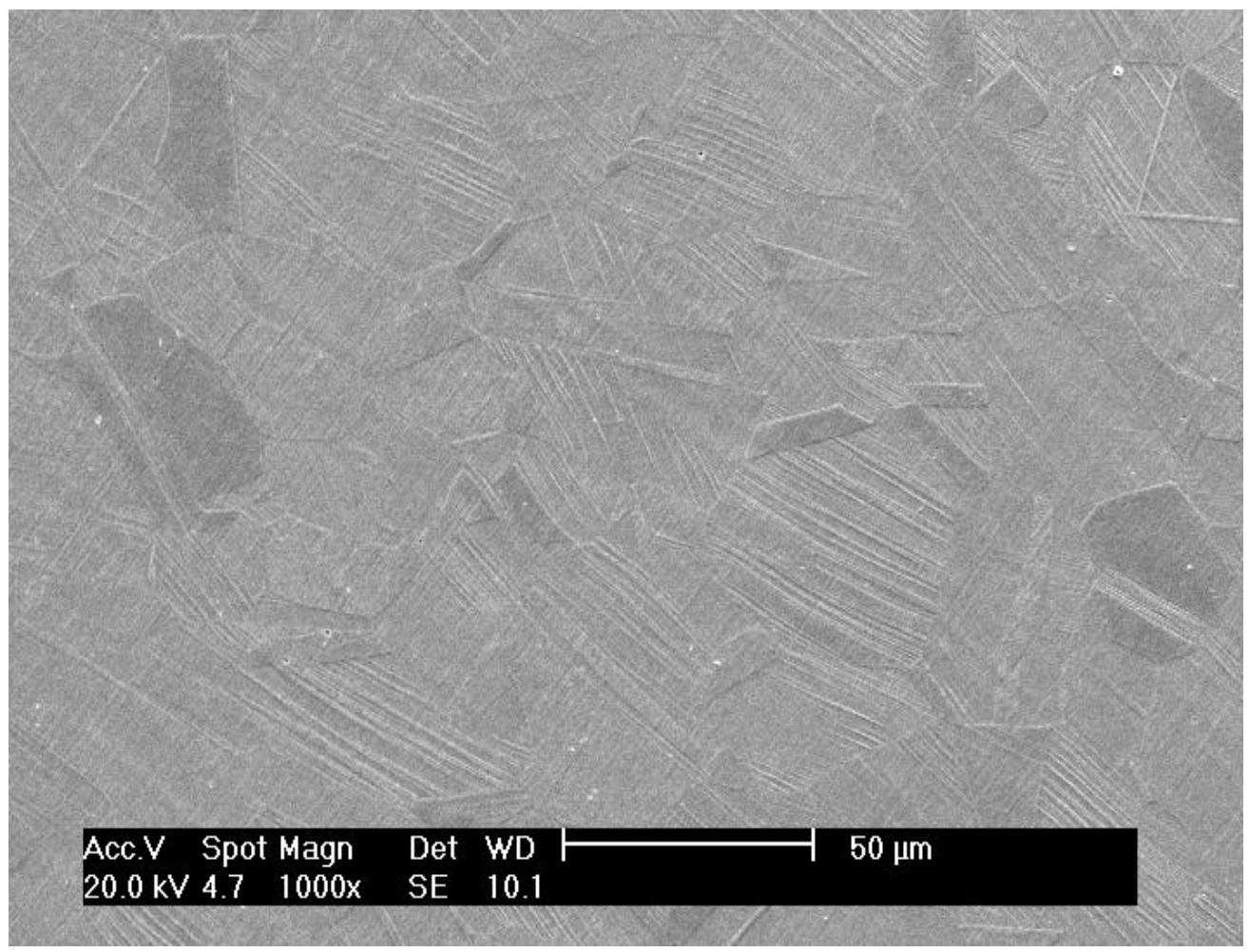

Figura 5.1.1(a). Micrografia obtida por microscopia eletrônica de varredura da amostra do aço inoxidável estudado após ataque eletrolítico em ácido oxálico. 
Na Figura 5.1.1 (b) está apresentada a microestrutura do aço na seção transversal da amostra marcada via raios laser, com detalhe da região da marcação do número oito.

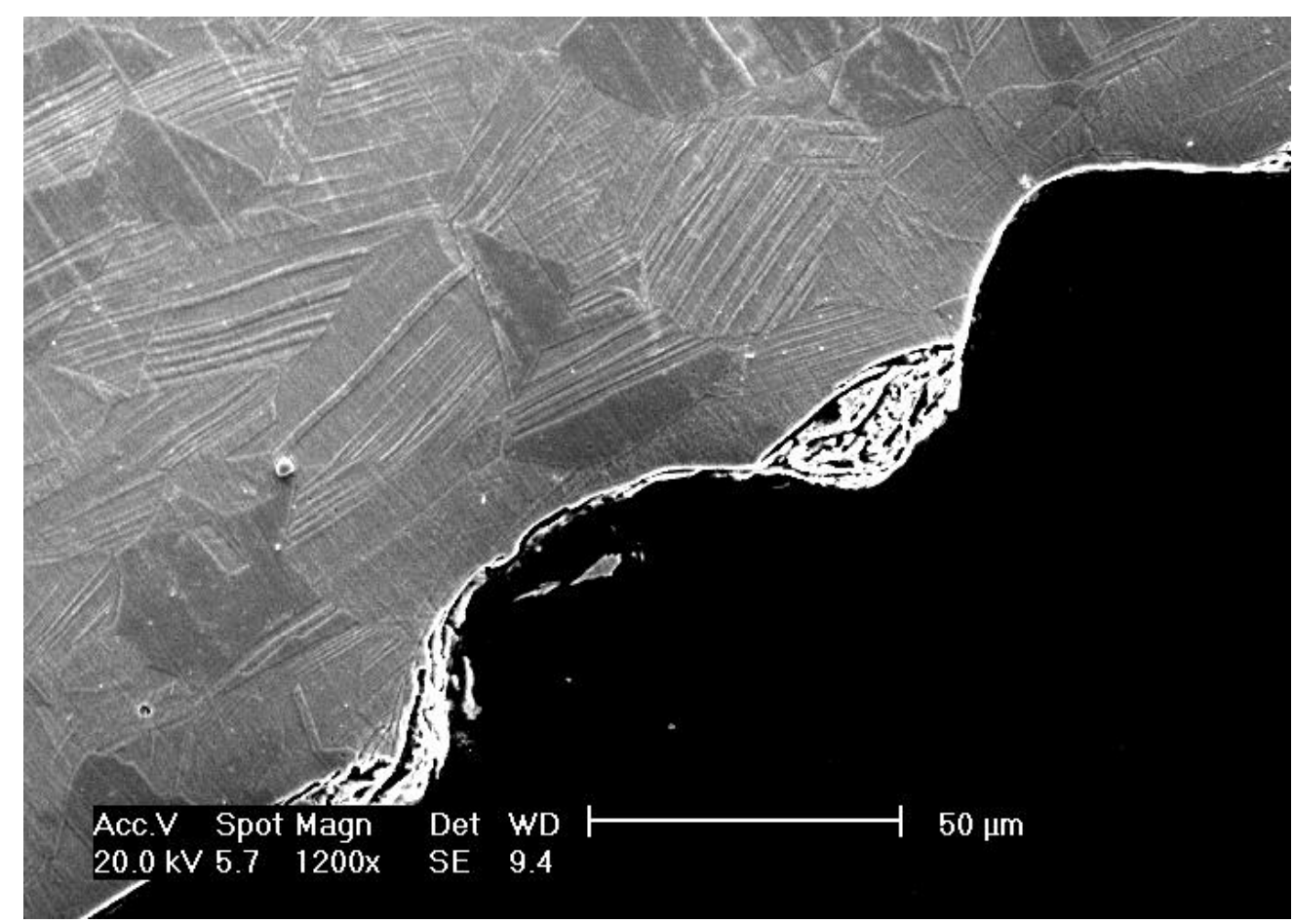

Figura 5.1.1(b). Micrografia obtida por microscopia eletrônica de varredura da seção transversal da amostra marcada a laser após ataque eletrolítico em ácido oxálico.

\subsection{Análise Química}

A análise química do material utilizado neste trabalho foi obtida pela técnica de espectroscopia de emissão óptica e os resultados obtidos encontram-se na Tabela 5.1.

Tabela 5.1. Elementos químicos presentes na amostra do aço inoxidável ABNT NBR ISO 5832-1, pela técnica de espectroscopia de emissão óptica.

\begin{tabular}{|c|c|l|c|c|c|c|c|c|c|}
\hline Elementos & $\mathbf{C}$ & $\mathbf{S i}$ & $\mathbf{M n}$ & $\mathbf{P}$ & $\mathbf{S}$ & $\mathbf{C r}$ & $\mathbf{M o}$ & $\mathbf{N i}$ & $\mathbf{F e}$ \\
\hline \% massa & 0,023 & 0,378 & 2,09 & 0,026 & 0,0003 & 18,32 & 2,59 & 14,33 & Bal. \\
\hline
\end{tabular}




\subsection{Potencial de circuito aberto}

As curvas de variação de potencial a circuito aberto em função do tempo de imersão em solução PBS, naturalmente aerada a $37^{\circ} \mathrm{C}$ estão apresentadas nas Figuras 5.3.1 e 5.3.2. Os ensaios foram realizados para cinquenta amostras do aço inoxidável austenítico ABNT NBR ISO 5832-1, nas condições: sem marcações e com marcações mecânicas e a laser. As amostras permaneceram imersas em solução por um período de 17 horas ou 61200 segundos, após o qual foram realizados os ensaios de espectroscopia de impedância eletroquímica.

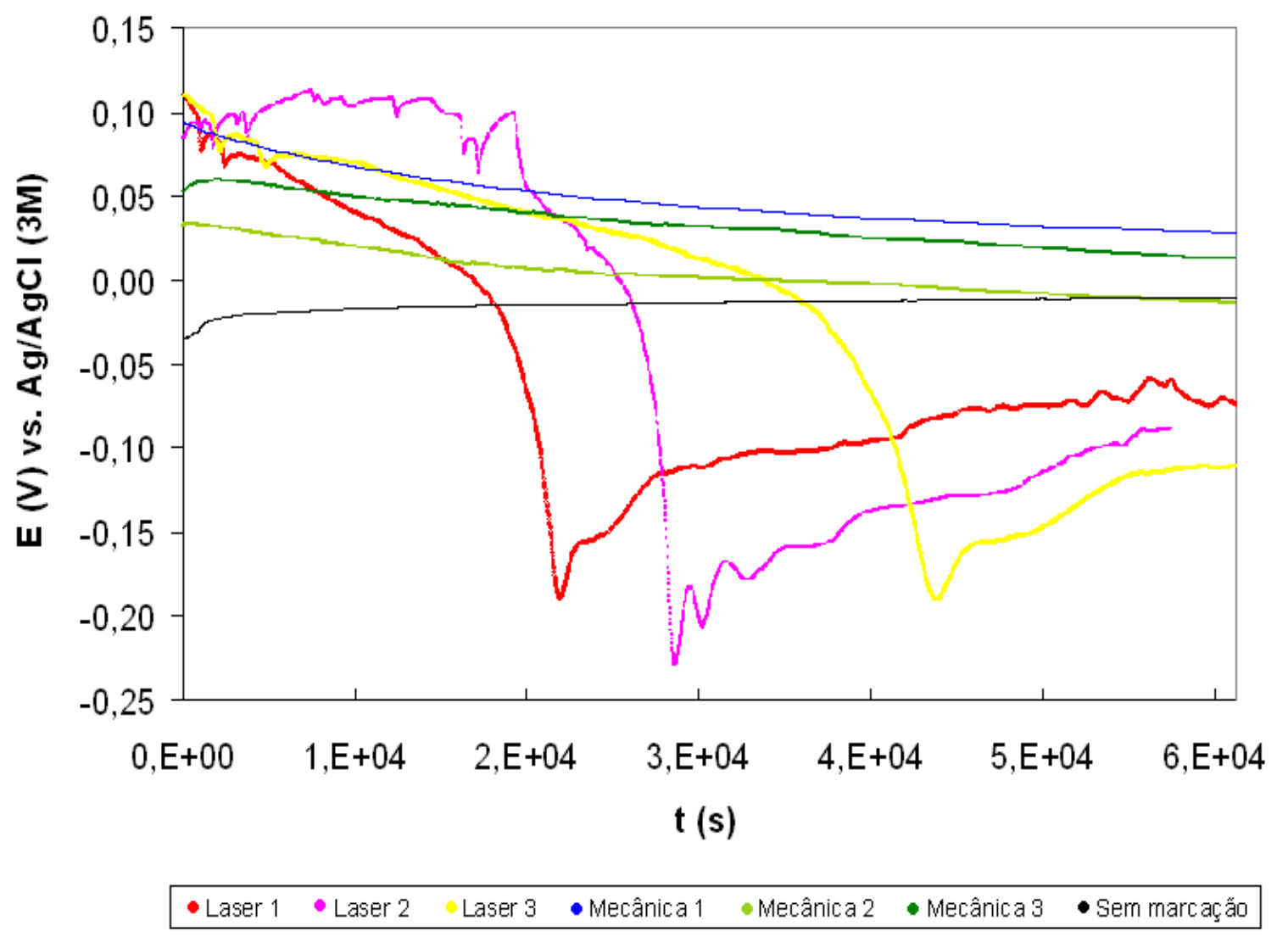

Figura 5.3.1. Potencial de corrosão em circuito aberto variando ao longo do tempo em solução PBS, naturalmente aerada a $37^{\circ} \mathrm{C}$ nas condições: sem marcação, com marcações a laser e mecânicas.

A análise da Figura 5.3.1 permite a compreensão de alguns fenômenos que se repetem para várias amostras dependendo do tipo de superfície avaliado. Por exemplo, a curva apresentada na cor preta, referente ao aço sem marcações, é representativa do montante de cinquenta ensaios realizados e apresenta 
potencial de circuito aberto mais constante pelo período avaliado, o que sugere a existência de um filme passivo mais estável sobre o aço. A partir dos primeiros 1,0.103s de imersão há um aumento no potencial, que com o passar do tempo exibe comportamento mais uniforme até atingir um valor da ordem de $-0,104 \mathrm{~V}$ $\mathrm{Ag} / \mathrm{AgCl}$ (3M) em 17horas de ensaio.

Com relação às amostras marcadas mecanicamente, verifica-se uma queda do potencial de corrosão ao longo do tempo de imersão. As três curvas apresentadas acima são exemplos da reprodutibilidade do comportamento apresentado, onde para a amostra nomeada na legenda como mecânica 3, curva de cor verde escura, ocorre um pequeno aumento de potencial para os primeiros tempos de imersão, $1,5.10^{3} \mathrm{~s}$, logo após uma queda suave e constante, semelhante às outras curvas representativas das amostras com marcações mecânicas; indicando também estabilidade do filme passivo formado sobre as mesmas. Todavia, para as amostras marcadas a laser foram observadas oscilações de potencial desde o início do ensaio, indicativas de tendência à quebra localizada do filme passivo, seguidas por recuperação de potencial, sugerindo recuperação do filme na região atacada. Após um período relativamente longo, o potencial com tendência de queda assume valores da ordem de $-0,15$ a $-0,20 \mathrm{~V}$, o qual é seguido por tendência de aumento de potencial para valores mais nobres e mais estáveis. A queda de potencial pode ser associada com o ataque de regiões mais ativas da superfície, devido à formação de micropilhas relacionadas com os defeitos gerados pela marcação a laser. $O$ ataque das regiões mais ativas pode ser considerado como uma "limpeza" parcial da superfície por ataque corrosivo que é seguida por uma superfície mais homogênea responsável pela recuperação de potencial nos momentos finais da imersão. 


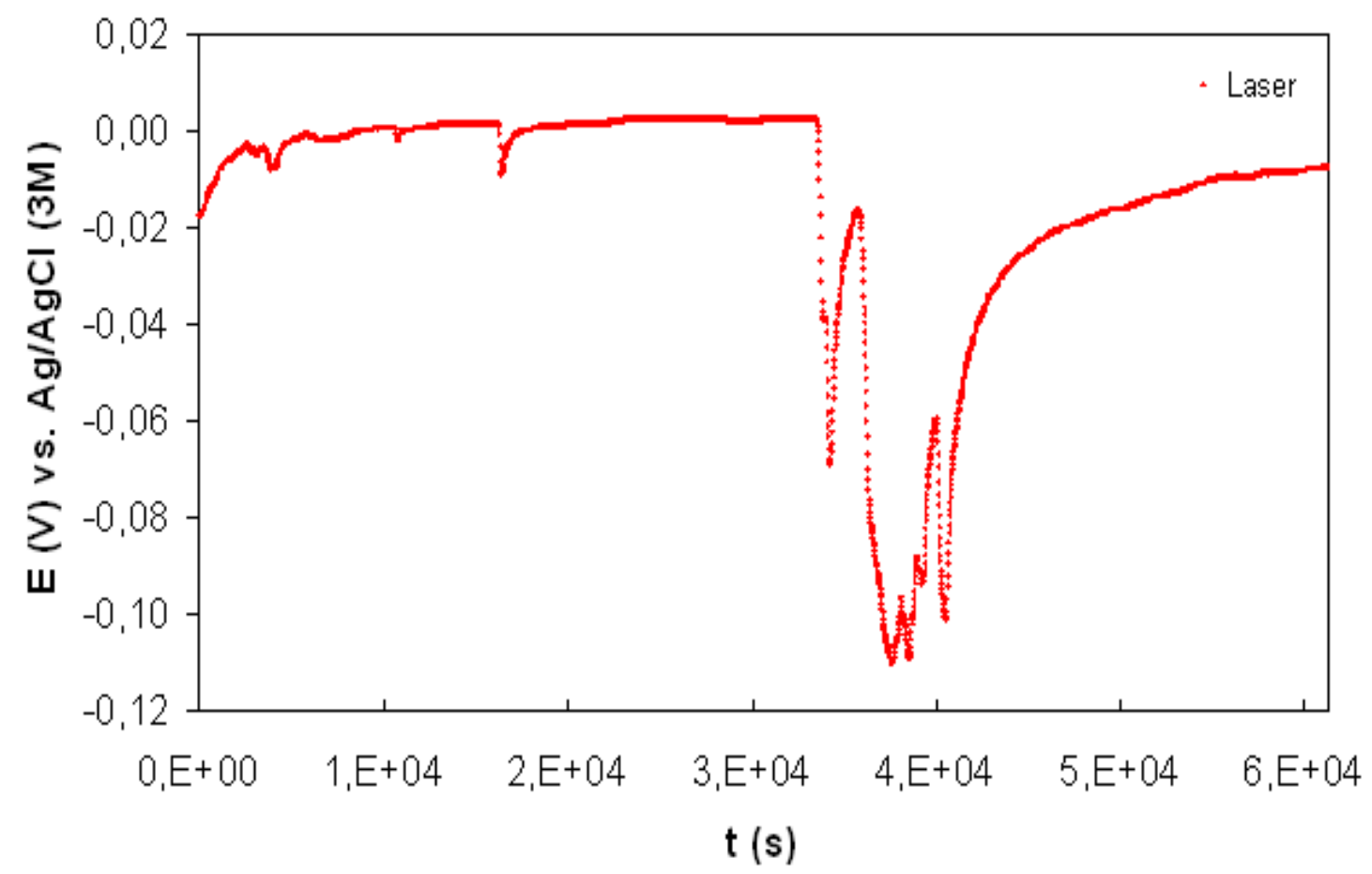

Figura 5.3.2. Potencial de corrosão em circuito aberto variando ao longo do tempo em solução PBS, naturalmente aerada a $37^{\circ} \mathrm{C}$ para a amostra marcada a laser.

Para o mesmo período de imersão na solução PBS, nas mesmas situações de ensaio, as curvas laser 1, 2 e 3 apresentadas em conjunto na Figura 5.3.1 mostram um comportamento diverso das outras condições de acabamento superficial. Para algumas amostras, o laser causa um contínuo decréscimo do potencial de corrosão em circuito aberto, chegando a valores mínimos, queda acentuada, em 22000s de imersão.

Em outros casos, como apresentado na curva laser 2, no princípio ocorre um aumento de potencial de corrosão, seguido de uma queda brusca e posterior aumento do potencial.

A Figura 5.3.2 mostra que a recuperação de potencial para valores mais nobres ocorre após período de intensa oscilação de potencial, provavelmente devido a um filme superficial mais defeituoso em comparação aos demais tipos de amostras.

De maneira geral, o laser afeta e muito a camada passiva formada sobre o aço inoxidável e conduz o potencial de corrosão a valores menos nobres quando comparados aos obtidos nas amostras sem marcações e com marcações mecânicas. 
A Figura 5.3.2 apresenta a instabilidade do filme passivo causada pelo laser, onde pode ser observada queda e aumento de potencial, o que indica a existência de um filme mais defeituoso que compromete a resistência à corrosão do biomaterial.

\subsection{Espectroscopia de Impedância Eletroquímica}

Nas figuras seguintes são mostrados os diagramas de espectroscopia de impedância eletroquímica de Bode (ângulo de fase e módulo de Z) e de Nyquist obtidos para o aço inoxidável austenítico ABNT NBR ISO $5832-1$ a $37^{\circ} \mathrm{C}$ em solução PBS, imediatamente após os ensaios de potencial de corrosão em circuito aberto.

Analisando-se o diagrama de Bode (ângulo de fase) apresentado na Figura 5.4.1, compreende-se que o aço apresenta um comportamento capacitivo, com os valores de ângulo de fase entre $-70^{\circ}$ e $-80^{\circ}$, na região de baixas frequências, comportamento que corresponde ao de metais passivos, sendo que as amostras sem marcações apresentam os menores valores. O diagrama mostra duas constantes de tempo. A primeira surge na região de médias frequências, caracterizada por um ombro entre 1 e $10 \mathrm{~Hz}$ para as superfícies gravadas a laser e entre 10 e $100 \mathrm{~Hz}$ para as superfícies gravadas mecanicamente e não gravadas. A segunda é indicada por um ombro em freqüências inferiores a $1 \mathrm{~Hz}$. A literatura tem observado este tipo de comportamento para aços inoxidáveis e associado a constante em altas frequências à interface óxido externo-meio e, a constante obtida em frequências médias à interface metal-óxido interno. [26-35]

Os diagramas de Bode (módulo de Z) apresentados na Figura 5.4.2, representam a reprodutibilidade obtida nos cinquenta ensaios para cada condição e mostra que a técnica de gravação influencia a impedância na região de baixas frequências, sendo as mais baixas obtidas para as amostras marcadas via laser, seguidas das com marcações mecânicas em comparação às sem marcações. Este fato evidencia uma queda na capacidade protetora do filme principalmente nas amostras gravadas a laser. 
Na Figura 5.4.1, os diagramas de Bode (ângulo de fase) mostram um platô largo com valores de ângulo de fase próximos a $-80^{\circ}$ em uma larga faixa de frequências, de médias a baixas, típico de materiais passivos. Os mais altos ângulos de fase em baixas frequências para as amostras sem marcação sugerem filmes passivos mais protetores. A queda nos ângulos de fase nas mais baixas frequências para as amostras marcadas são indicativas da deterioração das propriedades do filme passivo. Nas amostras gravadas a laser, o pico de ângulo de fase ocorre em frequências mais baixas em comparação aos demais tipos de amostras testadas, sugerindo que a camada mais externa do óxido apresenta-se menos protetora em relação às demais.

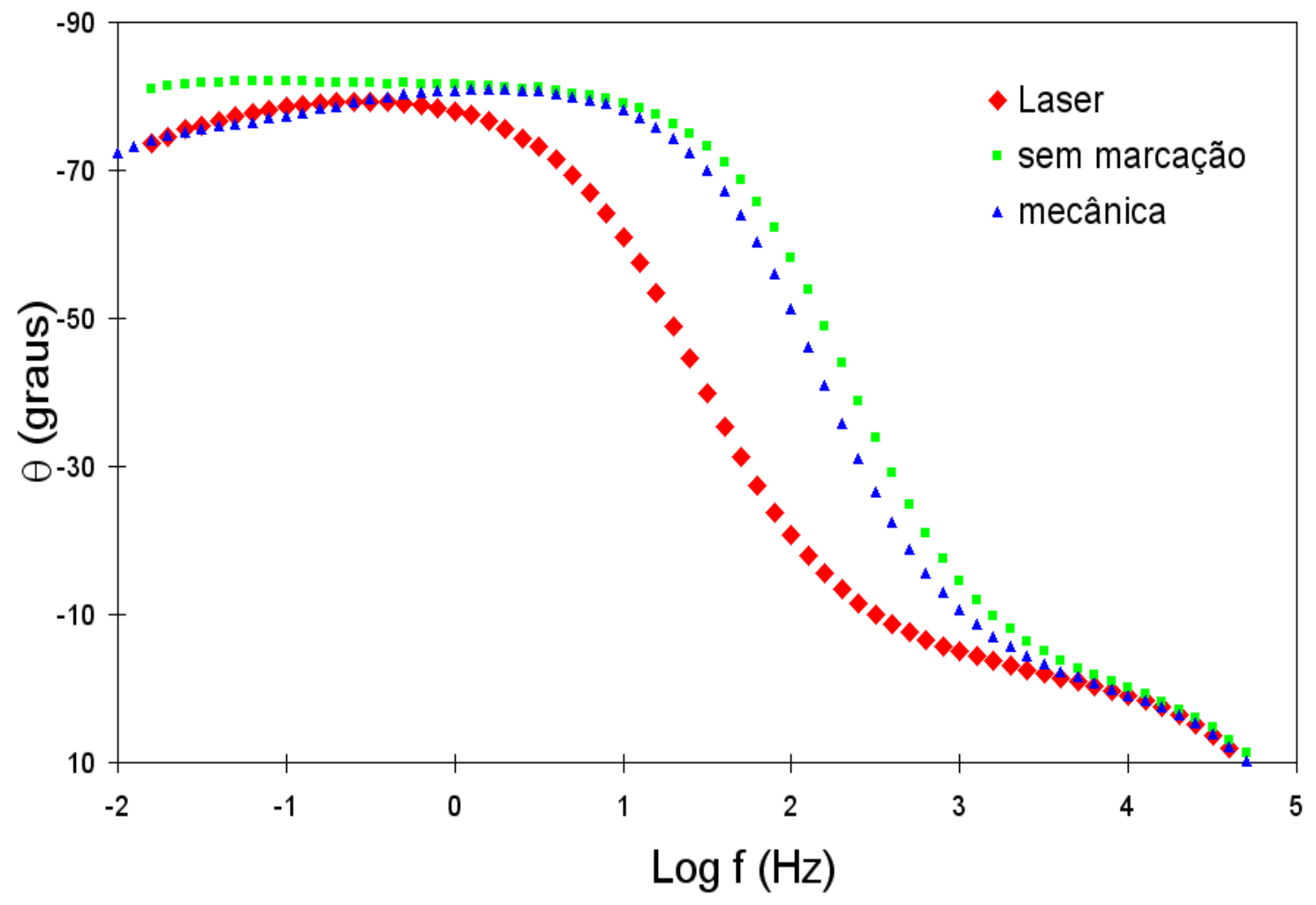

Figura 5.4.1. Diagrama de Bode (ângulo de fase) obtido após PCA para o aço inoxidável austenítico ABNT NBR ISO $5832-1 \mathrm{em}$ PBS a $37^{\circ} \mathrm{C}$ nas três condições analisadas. 


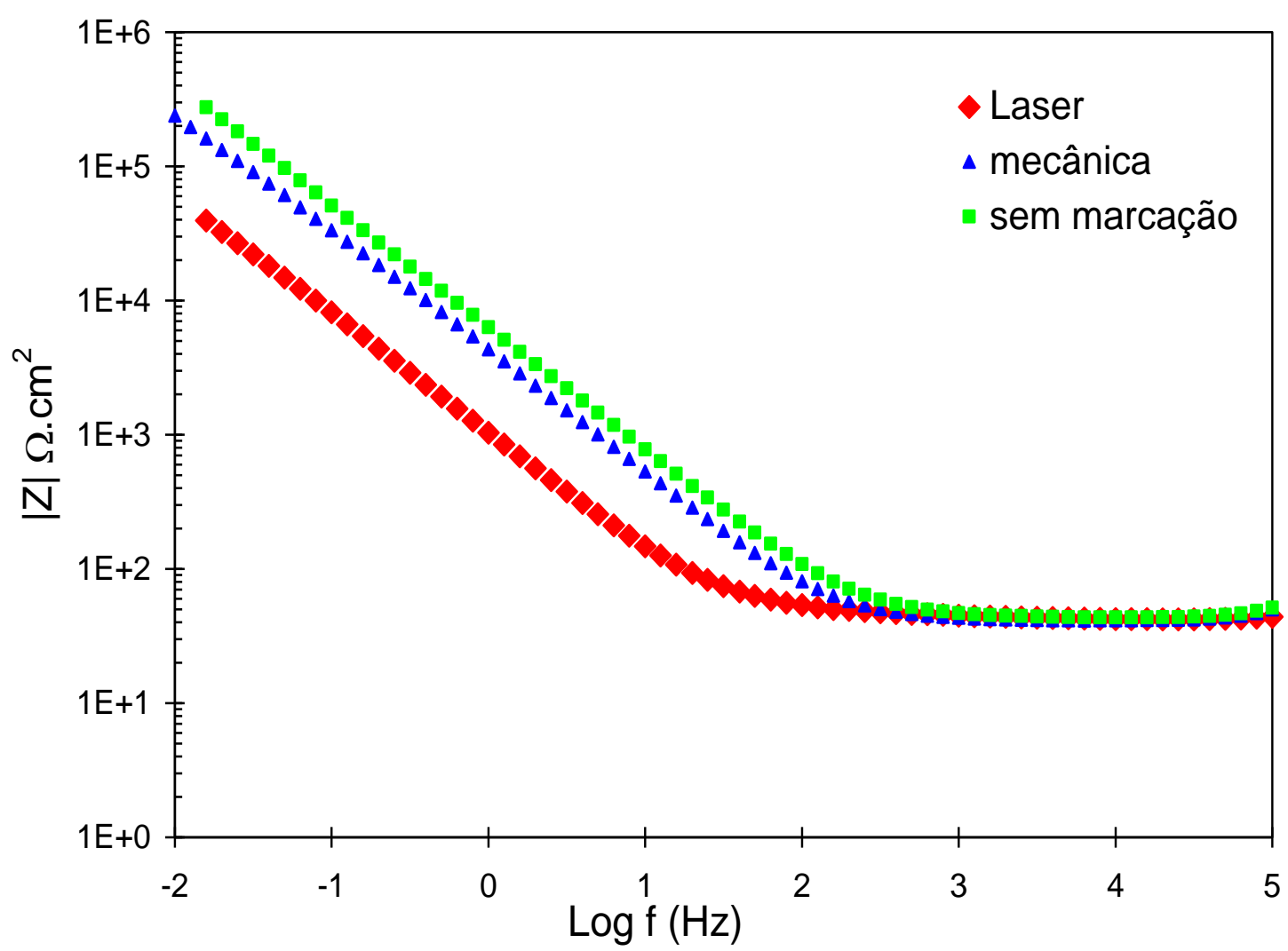

Figura 5.4.2. Diagrama de Bode (módulo de Z) obtido após PCA para o aço inoxidável austenítico ABNT NBR ISO $5832-1$ em PBS a $37^{\circ} \mathrm{C}$ nas três condições analisadas.

Nas Figuras 5.4.3 a 5.4.5 são apresentados separadamente diagramas de Nyquist com três ensaios em cada condição de acabamento superficial, observando-se a reprodutibilidade dos resultados. Na Figura 5.4.6 são apresentadas curvas representativas dos três tipos de superfície, a saber, amostras marcadas mecanicamente, a laser e sem marcações.

Para o mesmo período de imersão a partir do potencial de corrosão em circuito aberto, os diagramas de impedância de Nyquist apresentam comportamento capacitivo, típico de materiais passivos, embora mostrem valores de -Zimaginário inferiores para as amostras marcadas a laser; o que fica evidente na Figura 5.4.6, onde estão apresentados os resultados comparando o tipo de acabamento superficial analisado. Para um mesmo valor de frequência, as menores impedâncias estão associadas à amostra com marcação a laser. Em cada diagrama, os últimos pontos (para as amostras 1,2,3) referem-se à frequência de $10 \mathrm{mHz}$. 


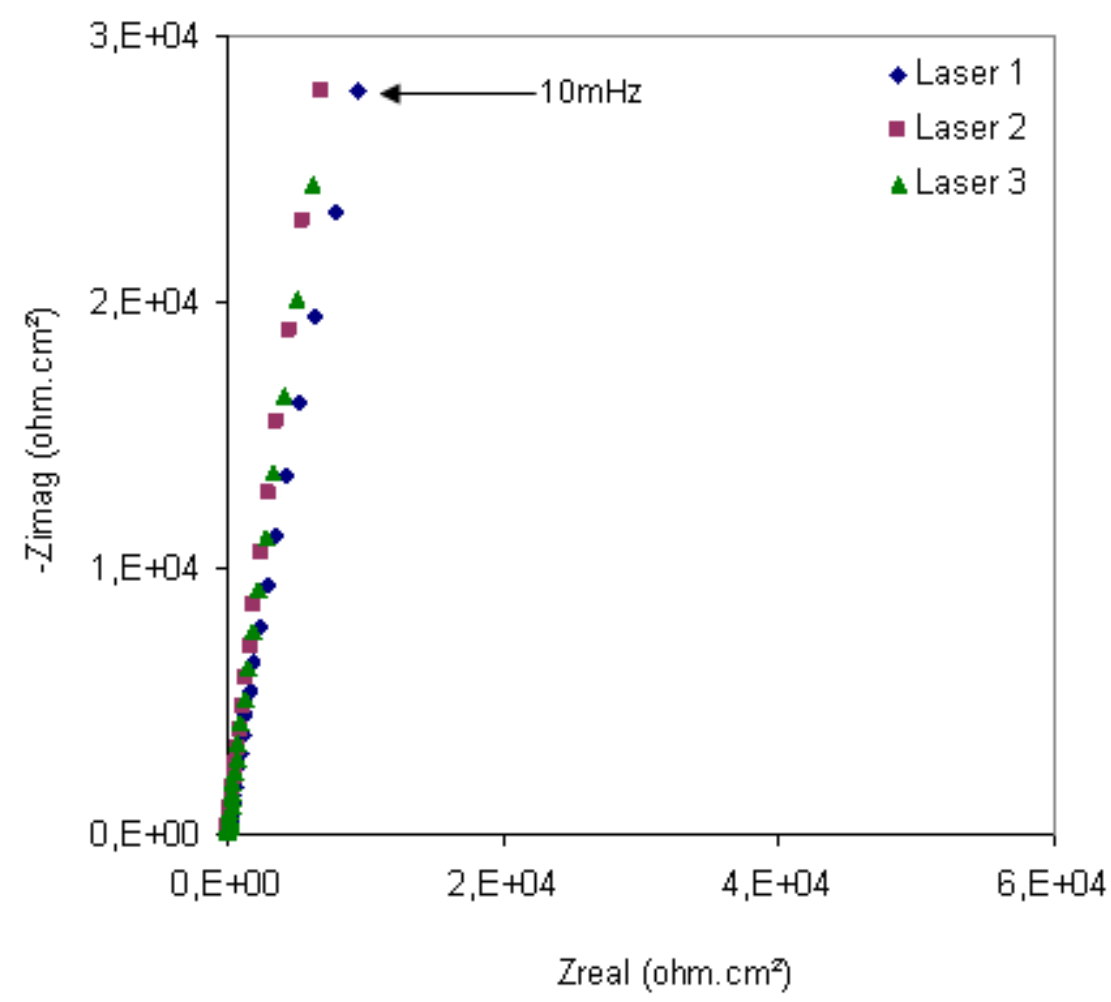

Figura 5.4.3. Diagrama de Nyquist obtido após PCA para o aço inoxidável austenítico ABNT NBR ISO $5832-1 \mathrm{em}$ PBS a $37^{\circ} \mathrm{C}$ para amostras marcadas a laser.

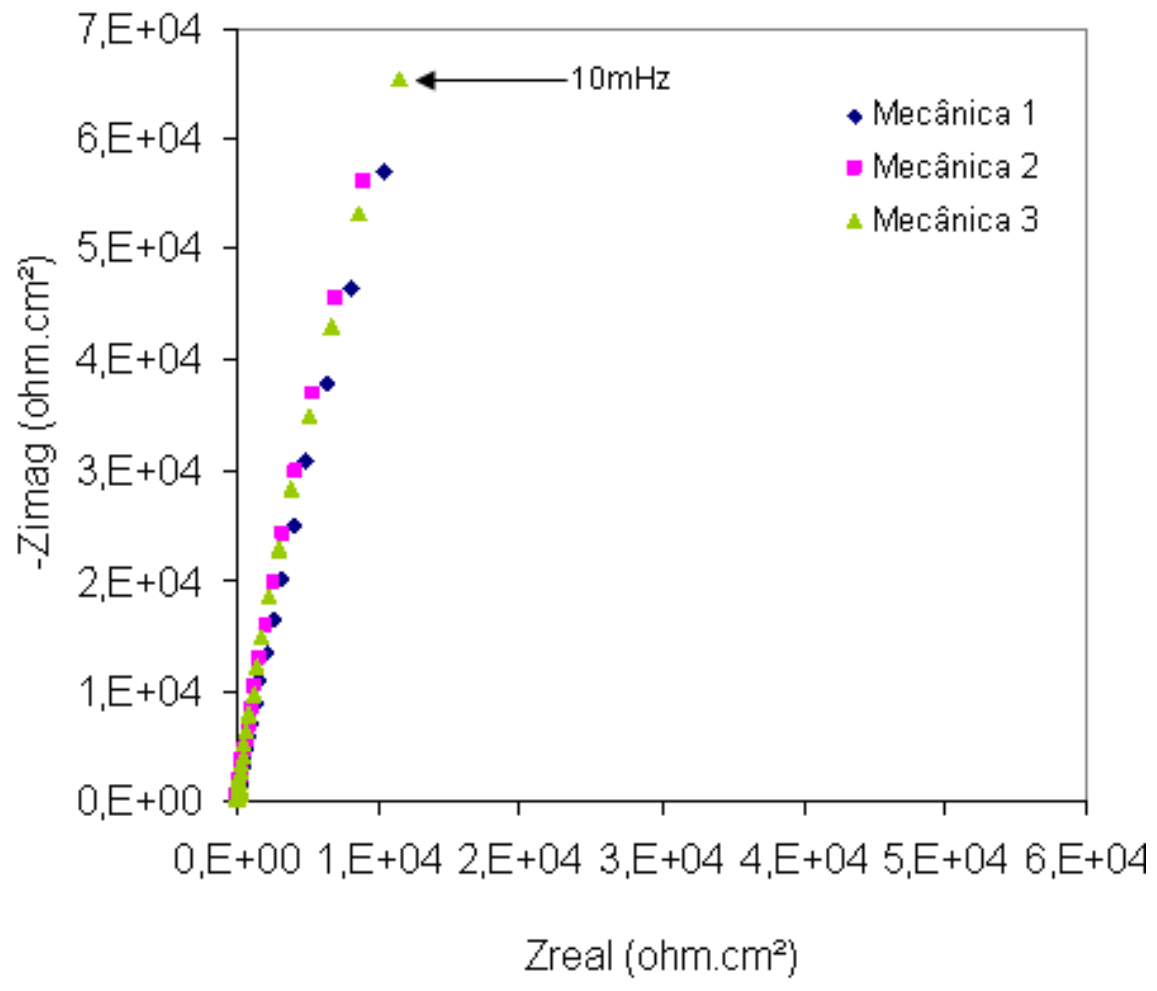

Figura 5.4.4. Diagrama de Nyquist obtido após PCA para o aço inoxidável austenítico ABNT NBR ISO 5832-1 em PBS a $37^{\circ} \mathrm{C}$ para amostras marcadas pela técnica mecânica. 


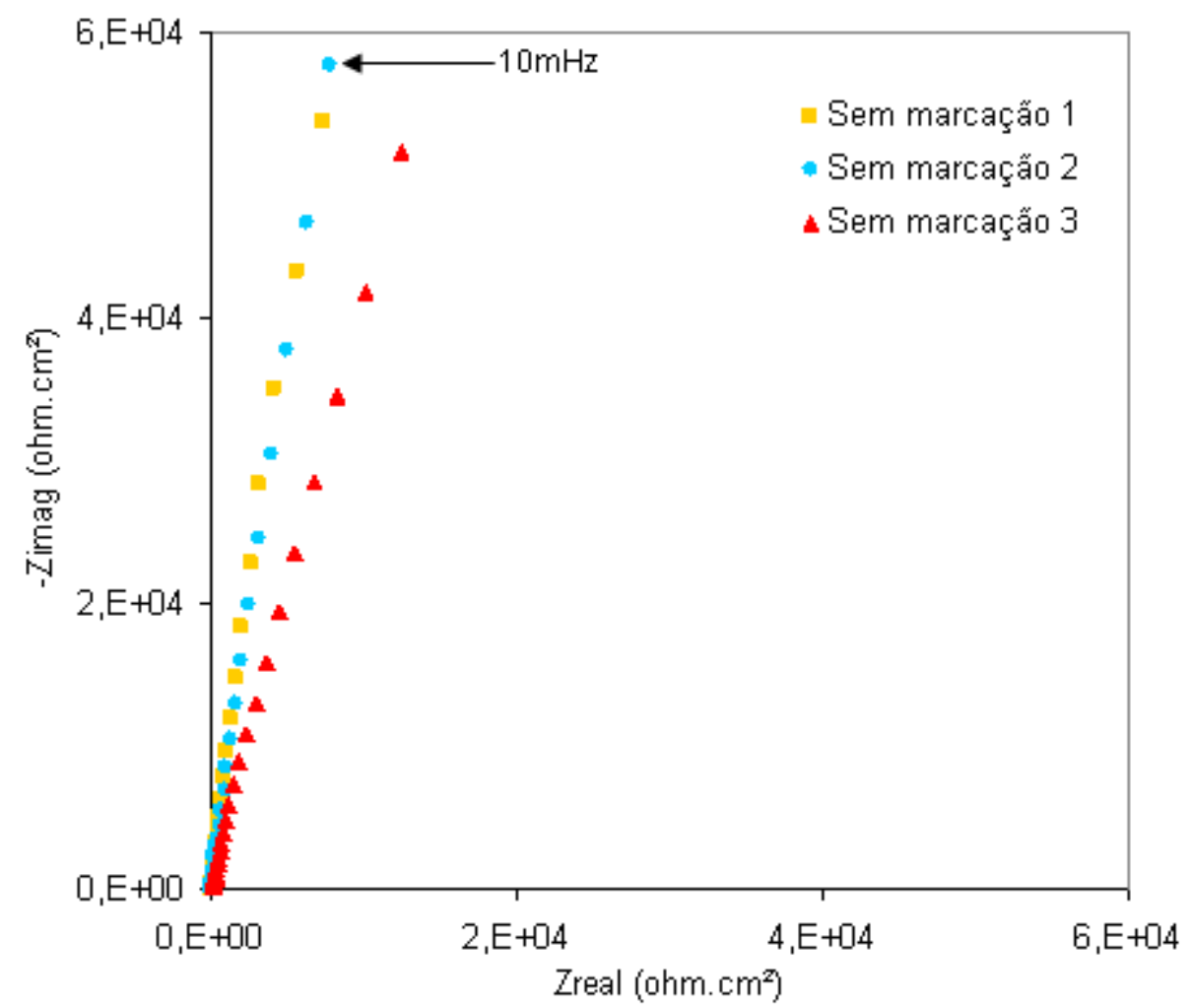

Figura 5.4.5. Diagrama de Nyquist obtido após PCA para o aço inoxidável austenítico ABNT NBR ISO $5832-1 \mathrm{em}$ PBS a $37^{\circ} \mathrm{C}$ para amostras não marcadas.

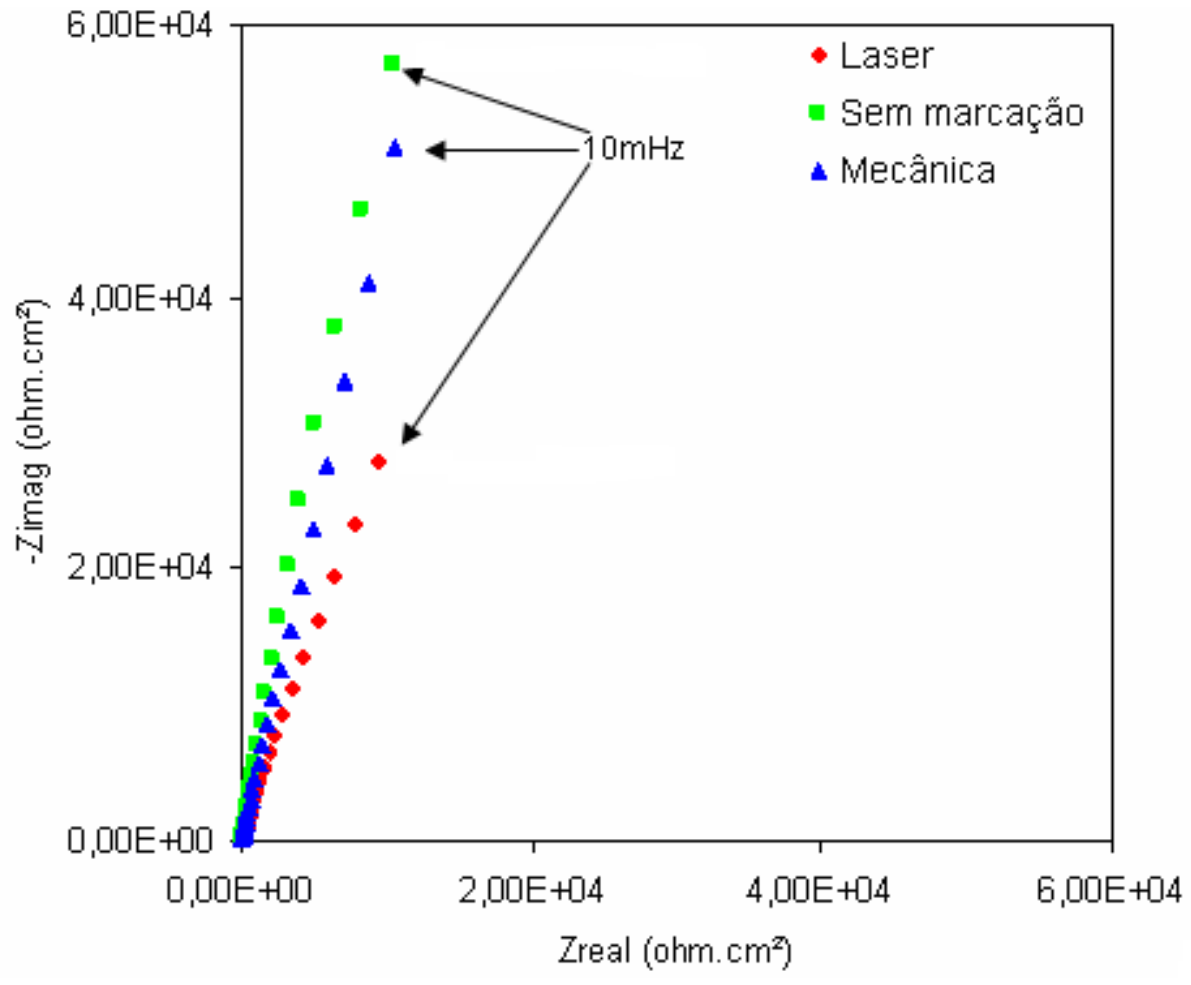

Figura 5.4.6. Diagrama de Nyquist obtido após PCA para o aço inoxidável austenítico ABNT NBR ISO 5832-1 em PBS a $37^{\circ} \mathrm{C}$ para amostras nas três condições analisadas. 
A Figura 5.4.6 apresenta diagramas de Nyquist para os três tipos de superfície mostrando impedâncias elevadas associadas a estas, mas a menor impedância associada à superfície marcada a laser.

Os circuitos elétricos equivalentes utilizados para ajustar os resultados de espectroscopia de impedância eletroquímica a fim de caracterizar a camada passiva do aço inoxidável utilizado neste estudo nas três condições analisadas estão apresentados na Figura 5.4.7.

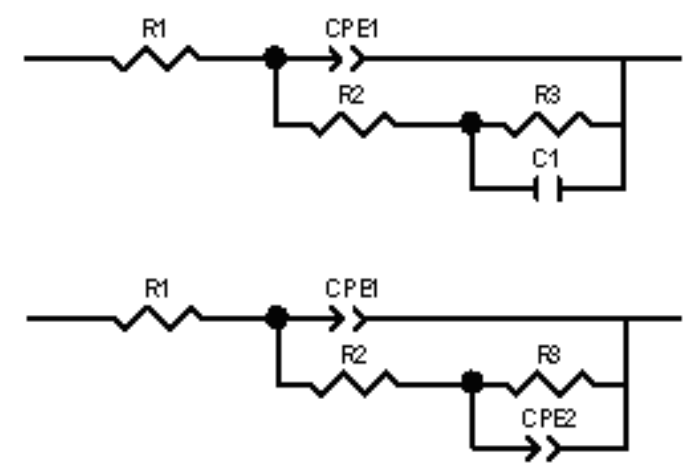

Figura 5.4.7. Circuitos Elétricos Equivalentes (CEE) utilizados para ajustar os dados experimentais obtidos por EIE para o aço inoxidável austenítico ABNT NBR ISO 5832-1, para as condições: (a) sem marcação e com marcação a laser e (b) com marcação mecânica.

Neste trabalho, o ajuste com o circuito apresentado em (a) foi adequado para descrever o comportamento eletroquímico de filme passivo formado sobre o aço inoxidável sem marcações e marcado via raios laser, já o descrito em (b) adequou-se às amostras do aço inoxidável marcadas mecanicamente, em ambos os casos, por dezessete horas de imersão em PBS.

Os valores dos componentes dos circuitos elétricos equivalentes apresentados acima, ajustados para as três condições de acabamento superficial estudadas estão na Tabela 5.2; CPEs são elementos de fase constante, C1 é um capacitor perfeito, R1 é a resistência da solução, R2 é a resistência do óxido externo, R3 é a resistência do óxido interno $e, n$ refere-se à potência do CPE. 
Tabela 5.2. Valores dos parâmetros ajustados utilizando os circuitos mostrados na Figura 5.4.7 (a)

e (b) para o aço inoxidável austenítico ABNT NBR ISO 5832-1, nas três condições estudadas.

\begin{tabular}{|c|c|c|c|c|c|c|c|c|}
\hline & $\begin{array}{c}\mathrm{R} 1 \\
\left(\Omega \cdot \mathrm{cm}^{2}\right)\end{array}$ & $\begin{array}{c}\mathrm{CPE} 1 \\
\left(\mathrm{~cm}^{-2} \mathrm{~s}^{-\mathrm{n}} \Omega\right)\end{array}$ & $\mathrm{n} 1$ & $\begin{array}{c}\mathrm{R} 2 \\
\left(\Omega . \mathrm{cm}^{2}\right)\end{array}$ & $\begin{array}{c}\mathrm{CPE} 2 \\
\left(\mathrm{~cm}^{-2} \mathrm{~s}^{-1} \Omega\right)\end{array}$ & $\mathrm{n} 2$ & $\begin{array}{c}\mathrm{C} 1 \\
\left(\mathrm{~cm}^{-2} \mathrm{~s}^{-\mathrm{n}} \Omega\right)\end{array}$ & $\begin{array}{c}\mathrm{R} 3 \\
\left(\Omega . \mathrm{cm}^{2}\right)\end{array}$ \\
\hline $\begin{array}{c}\text { Sem } \\
\text { marcas }\end{array}$ & 44,23 & $2,8.10^{-5}$ & 0,921 & $1,7.10^{5}$ & - & - & $2,2.10^{-6}$ & $6,8.10^{6}$ \\
\hline Laser & 42,84 & $1,5.10^{-4}$ & 0,861 & 81,36 & - & - & $3,4.10^{-5}$ & $4,2.10^{5}$ \\
\hline Mecânica & 41,62 & $4,2.10^{-5}$ & 0,917 & $2,1.10^{5}$ & $8,8.10^{-6}$ & 0,796 & - & $1,8.10^{6}$ \\
\hline
\end{tabular}

Conforme estabelecido na literatura [16-19], os filmes passivos formados sobre os aços inoxidáveis apresentam caráter dúplex, possuindo uma região interna rica em óxidos de cromo e uma região externa rica em óxidos e hidróxidos de ferro. Na interface solução / filme passivo, R2 é a resistência da camada externa, composta majoritariamente por óxidos e hidróxidos de ferro e CPE1 é a capacitância associada a ela. Os menores valores foram encontrados para as amostras com marcações a laser. A resistência R3, da camada interna, que é relacionada com os óxidos de cromo, também apresentou valores diferentes para cada tipo de condição de superfície analisada; sendo que para a amostra marcada a laser, os valores são uma ordem de grandeza inferiores às demais condições e a capacitância associada a ela, apresenta valores uma ordem de grandeza superiores aos obtidos nas amostras com marcações mecânicas e sem marcações, o que indica filmes passivos mais defeituosos para as amostras gravadas a laser.

Os diagramas de Bode e de Nyquist mostrando a comparação entre os resultados experimentais e os obtidos com os ajustes utilizando os circuitos apresentados, bem como os erros associados a cada um dos parâmetros do circuito e os valores de chi-quadrado são mostrados no APÊNDICE.

\subsection{Polarização Potenciodinâmica Cíclica}

Nas figuras seguintes estão mostradas as curvas de polarização potenciodinâmica cíclica resultantes dos ensaios conduzidos em solução PBS naturalmente aerada a $37^{\circ} \mathrm{C}$, que corresponde à temperatura corpórea, com eletrodo de referência de $\mathrm{Ag} / \mathrm{AgCl}(3 \mathrm{M})$ e contra-eletrodo de platina platinizada. A 
velocidade de varredura utilizada, na direção anódica, foi de $0,167 \mathrm{mV} . \mathrm{s}^{-1}$ de acordo com a norma ABNT NBR 15613-2:2010 [47], a partir do potencial de circuito aberto.

Os resultados para as amostras marcadas a laser estão exibidos na Figura 5.5.1. Este resultado representa o efeito do laser na susceptibilidade à corrosão do aço; as curvas apresentam um aumento acentuado na densidade de corrente para valores desde cerca de $+0,4 \mathrm{~V}(\mathrm{Ag} / \mathrm{AgCl})$ até $0,6 \mathrm{~V}(\mathrm{Ag} / \mathrm{AgCl})$. Esta variabilidade é esperada para superfícies heterogêneas como é o caso das amostras com marcações via raios laser.

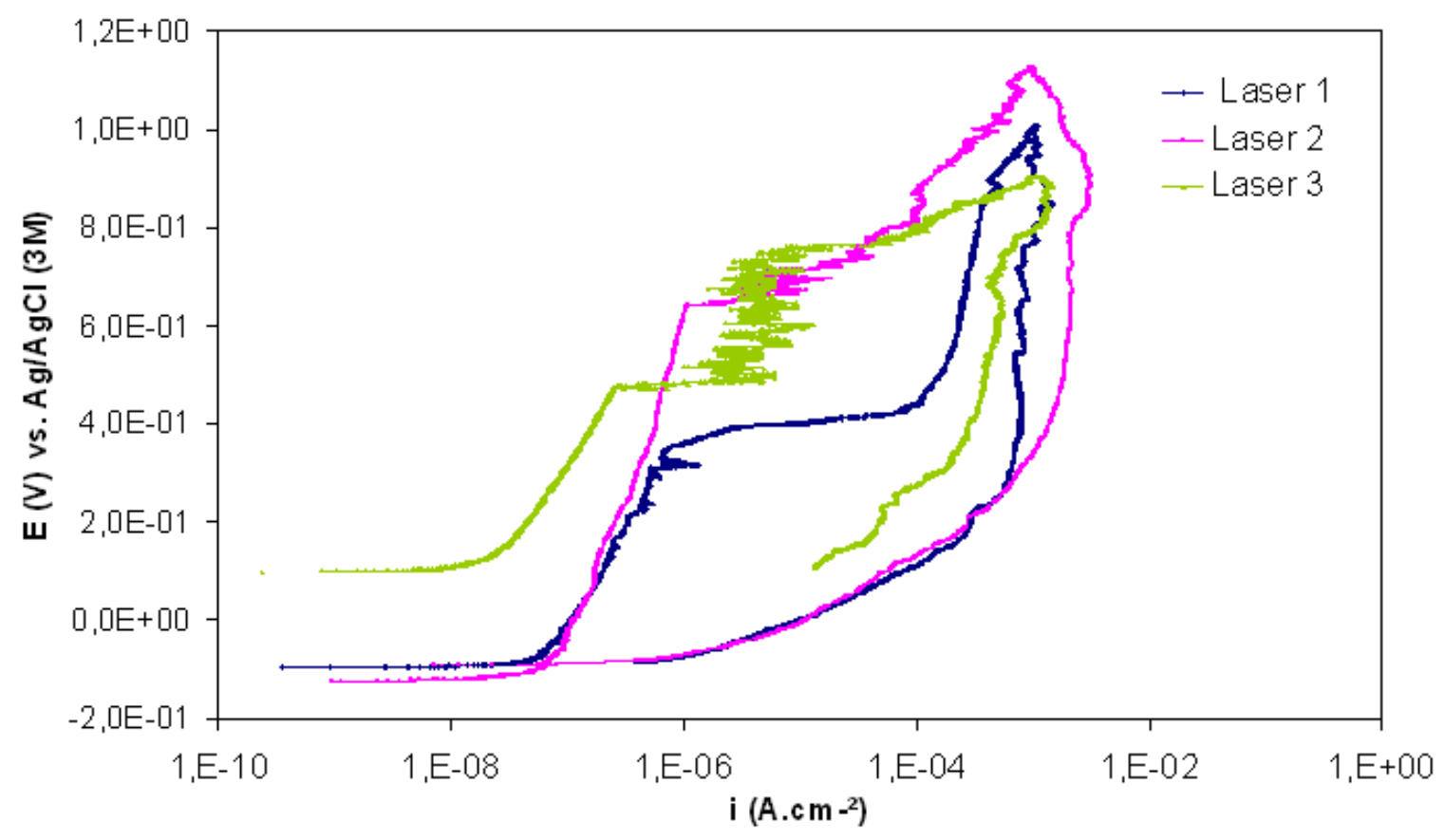

Figura 5.5.1. Curvas de polarização cíclica obtidas no sentido anódico para o aço inoxidável austenítico ABNT NBR ISO 5832-1 em PBS a $37^{\circ} \mathrm{C}$ para amostras marcadas a laser.

$\mathrm{Na}$ Figura 5.5.2 estão apresentadas as curvas de polarização potenciodinâmicas cíclicas para o aço inoxidável austenítico ABNT NBR ISO 5832-1 com marcações mecânicas e, na Figura 5.5 .3 são mostradas as curvas de polarização potenciodinâmicas cíclicas para as amostras do referido aço sem marcações. A Figura 5.5.4 mostra as três condições estudadas apresentadas em conjunto, para efeito de comparação das técnicas de marcação avaliadas com as amostras não marcadas; a análise desta figura evidencia que o laser causa um efeito deletério nas amostras do referido aço utilizado para biomateriais, uma vez que diminui a sua resistência à corrosão, quando comparado às outras condições. 


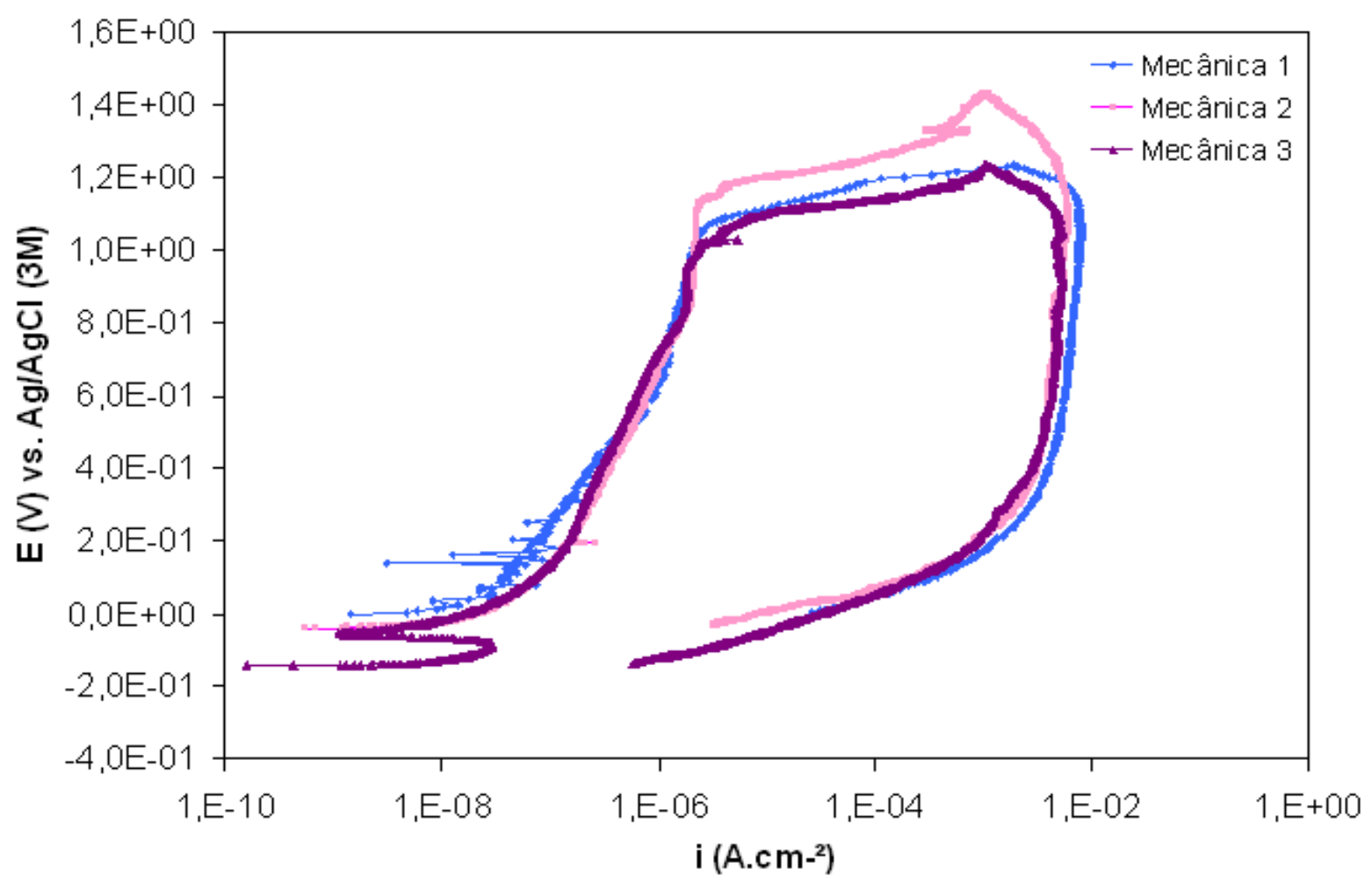

Figura 5.5.2. Curvas de polarização cíclica obtidas no sentido anódico para o aço inoxidável austenítico ABNT NBR ISO $5832-1$ em PBS a $37^{\circ} \mathrm{C}$ para amostras marcadas mecanicamente.

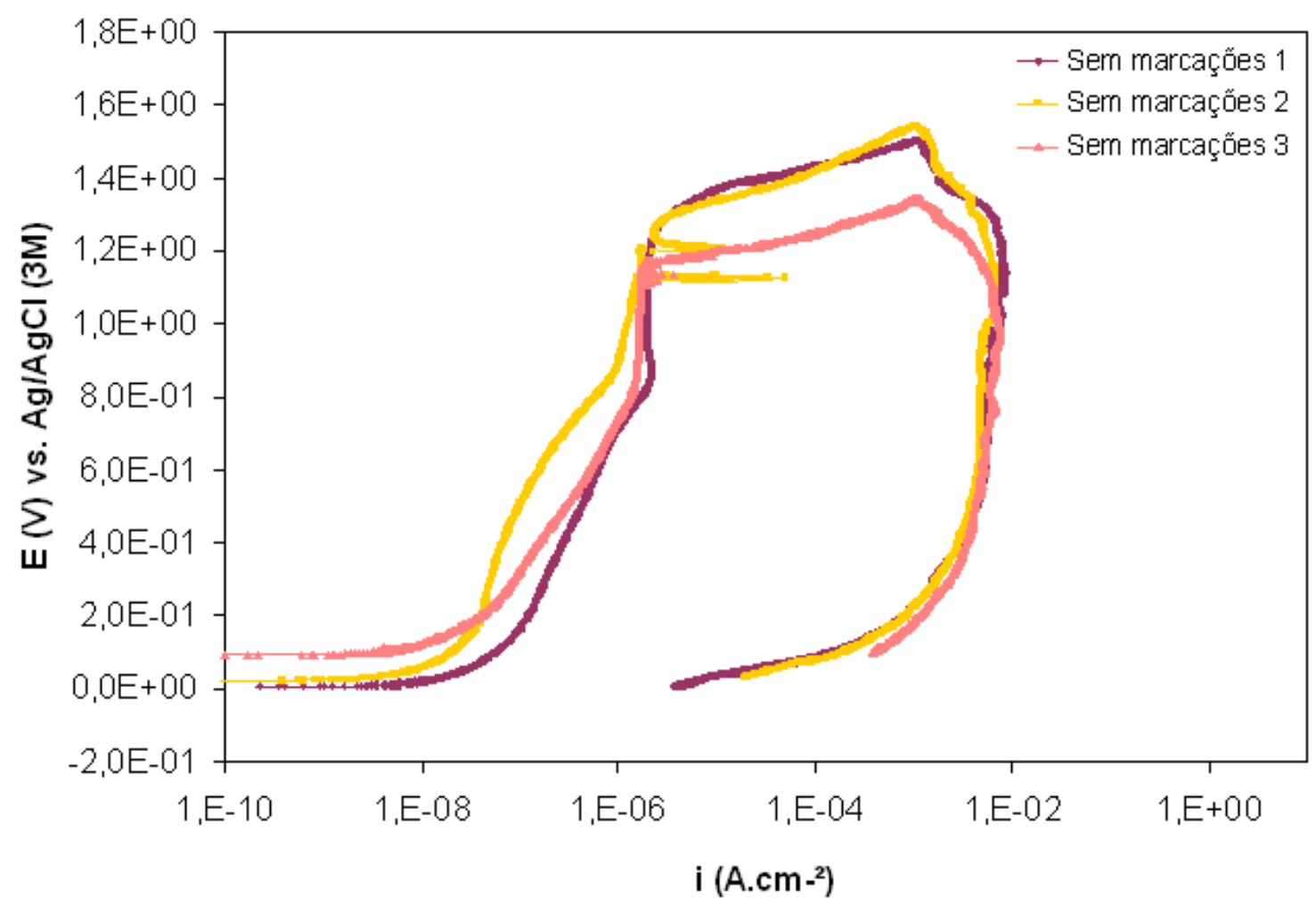

Figura 5.5.3. Curvas de polarização cíclica obtidas no sentido anódico para o aço inoxidável austenítico ABNT NBR ISO 5832-1 em PBS a $37^{\circ} \mathrm{C}$ para amostras sem marcações. 
Os resultados das Figuras 5.5.2 e 5.5.3 mostram boa reprodutibilidade para as amostras ensaiadas nestas duas condições, sem marcações e com marcação mecânica. Os elevados valores de aumento de corrente nos dois casos podem ser associados com a reação de evolução de oxigênio e, para avaliar se houve ataque localizado é necessária a observação microscópica da superfície após o ensaio.

Antes do aumento de corrente são observadas densidades de corrente, da ordem de $10^{-6}$ a $10^{-7}\left(\mathrm{~A} \mathrm{~cm}^{-2}\right)$, para as três condições testadas, as quais são típicas de materiais passivos, conforme esperado e, está apresentado na Figura 5.5 .4 .

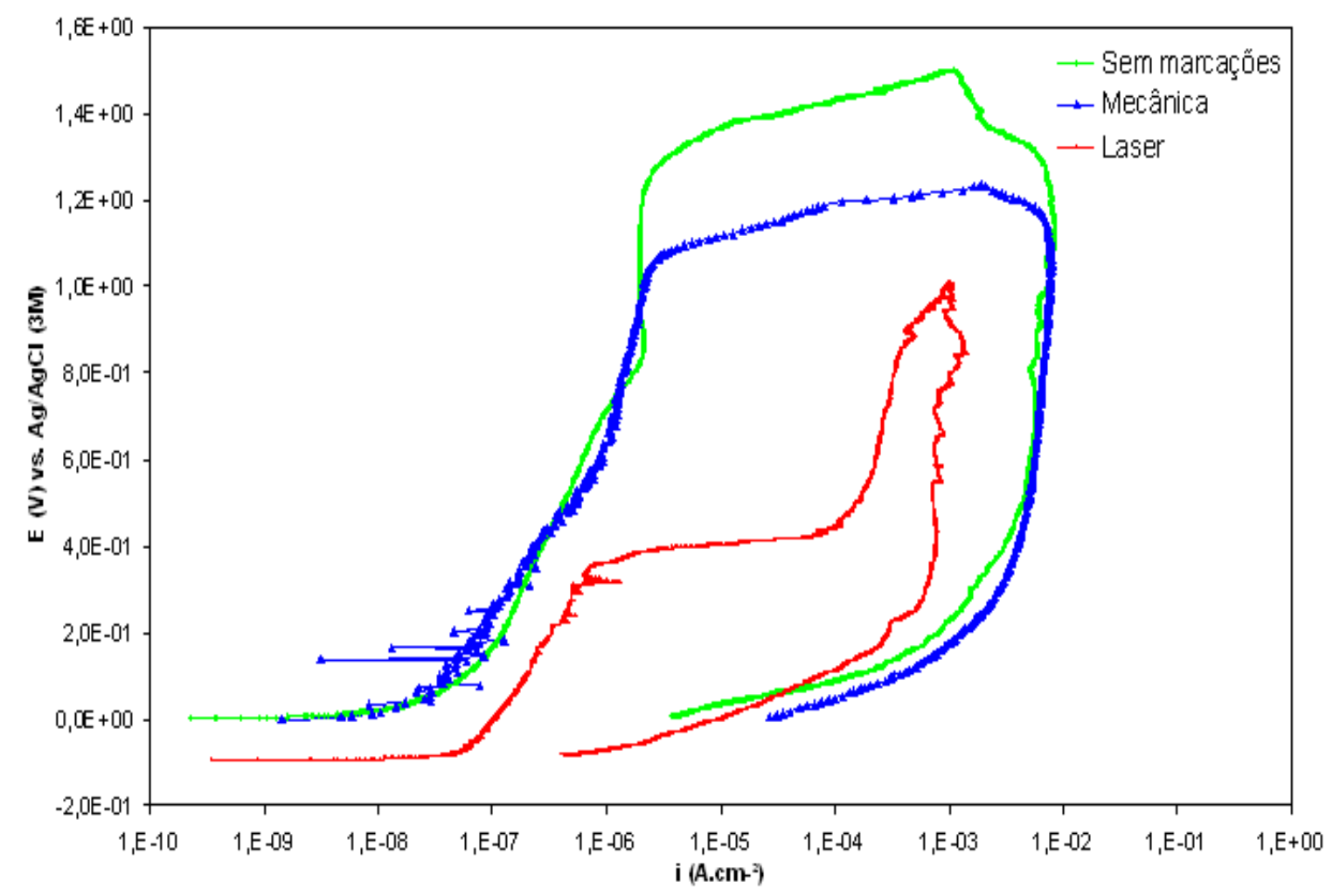

Figura 5.5.4. Curvas de polarização cíclica obtidas no sentido anódico para o aço inoxidável austenítico ABNT NBR ISO 5832-1 em PBS a $37^{\circ} \mathrm{C}$ para as três condições de amostras avaliadas.

Os potenciais de pite para as amostras com marcação a laser são bem inferiores aos observados para as amostras marcadas mecanicamente e nas não marcadas, o que evidencia a maior susceptibilidade da região marcada a laser à corrosão por pite. A comparação das curvas de polarização dos vários tipos de superfícies testados também mostra que antes da quebra do filme passivo nas 
amostras com marcação a laser já se nota grandes oscilações de corrente, que indicam a nucleação de pites.

A grande histerese observada nas curvas para as três condições testadas indica que há formação de pites nos três casos e que a tendência à repassivação dos pites é muito baixa no meio de ensaio adotado.

O ensaio de polarização potenciodinâmica cíclica foi realizado à taxa de varredura de $0,167 \mathrm{mV} . \mathrm{s}^{-1}$. Esta velocidade, relativamente lenta, indicada na norma ABNT NBR 15613-2:2010 [47], foi utilizada em todos os ensaios a fim de que proporcionasse tempo de estabilização das reações na interface do filme passivo com o meio de ensaio. Pela análise da figura em questão, observa-se que apesar do efeito da velocidade de varredura, o filme passivo já apresenta caráter instável desde os primeiros momentos do ensaio (desde o potencial de corrosão em circuito aberto) bem antes do potencial de quebra; o que sugere que o óxido formado sobre a superfície das amostras submetidas ao processo de gravação via raios laser apresenta maior quantidade de defeitos do que o encontrado nas outras condições estudadas. Estes defeitos são resultantes do efeito térmico causado pelo laser, que funde o material gerando a impressão desejada e, são relacionados às mudanças de caráter topográfico das superfícies marcadas como, por exemplo, depressões, picos, vales e respingos, além de possivelmente gerarem lacunas de íons metálicos e trincas na camada de óxido.

Com base nas curvas de polarização potenciodinâmicas anódicas foram obtidos os valores de potencial de corrosão $\left(E_{c o r r}\right)$ e potencial de pite $\left(E_{\text {pite }}\right)$ para as amostras marcadas mecanicamente e por raios laser, bem como sem marcações, como estão apresentados na Tabela 5.3.

Tabela 5.3. Potenciais de corrosão, de pite e de quebra de filme para amostras com marcações a laser, mecânicas e sem marcações. (Média e desvio calculados para dez resultados em cada condição de superfície).

\begin{tabular}{ccc}
\hline Marcação / Potencial & $E_{\text {corr }}(\mathrm{V})$ & $E_{\text {pite }}(\mathrm{V})$ \\
\hline Laser & $-0,088 \pm 0,203$ & $0,612 \pm 0,207$ \\
\hline Mecânica & $0,028 \pm 0,184$ & $0,998 \pm 0,097$ \\
\hline Sem Marcação & $0,0068 \pm 0,019$ & $1,162 \pm 0,082$ \\
\hline
\end{tabular}




\subsection{Propriedades eletrônicas do filme passivo - Abordagem de Mott- Schottky}

Os resultados apresentados até este momento se utilizaram de técnicas eletroquímicas clássicas a fim de se avaliar o comportamento do aço inoxidável austenítico ABNT NBR ISO 5832-1 imerso por dezessete horas em solução salina de fosfato tamponada (PBS), que simula os fluidos corpóreos, a temperatura de $37^{\circ} \mathrm{C}$, marcados com as duas técnicas de marcação mais utilizadas industrialmente. Todos os resultados indicaram maior susceptibilidade à corrosão localizada nas amostras marcadas via raios laser, indicando a existência de um filme passivo instável, não homogêneo e defeituoso.

Dada a necessidade de caracterização da influência da técnica de gravação empregada sobre o comportamento do biomaterial frente à corrosão, foi utilizada a abordagem de Mott-Schottky para se avaliar as propriedades eletrônicas do filme passivo formado sobre o referido aço. A Figura 5.6.1 mostra gráficos para o aço inoxidável sem marcações, que são representativos da reprodutibilidade obtida nos ensaios realizados.

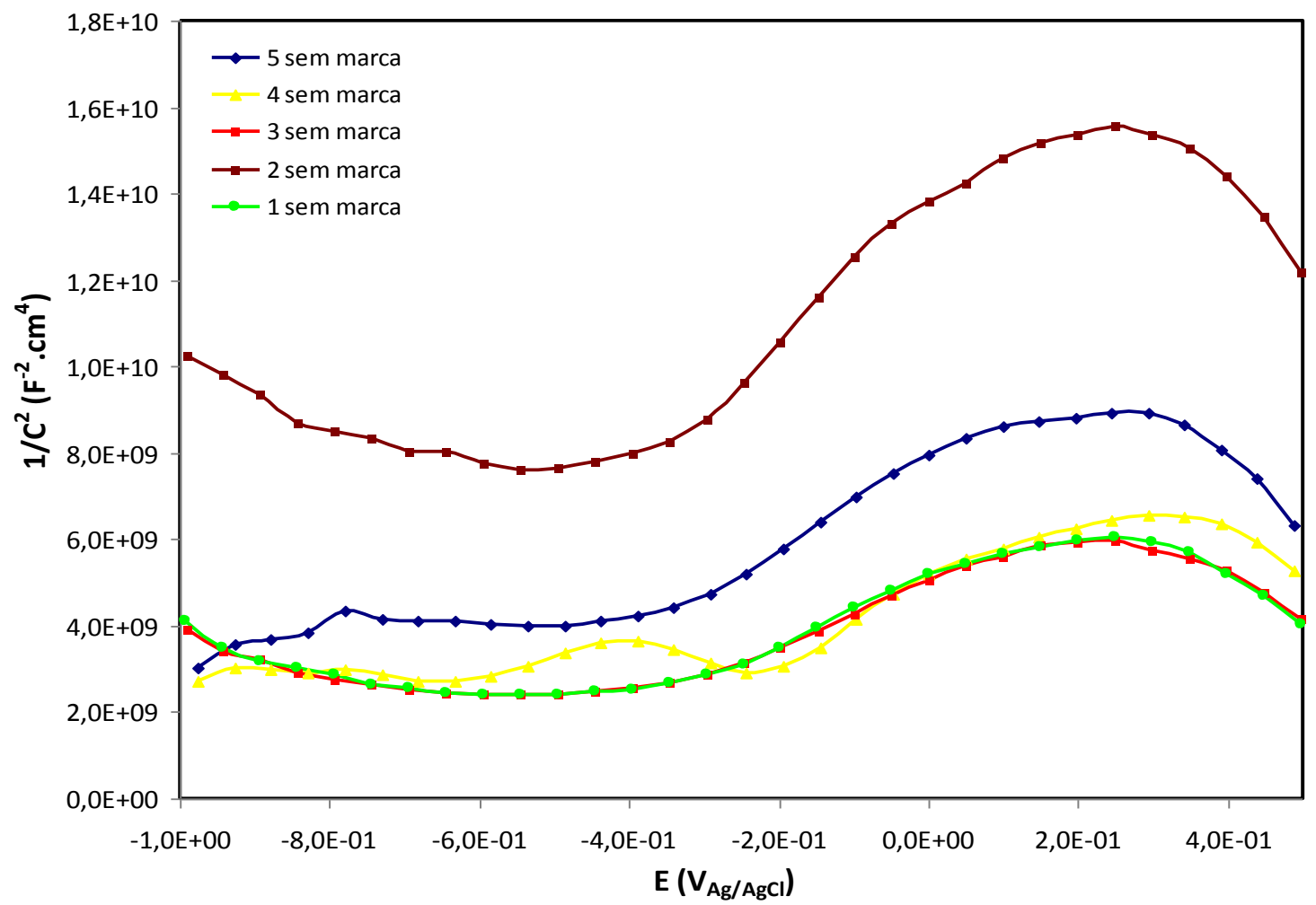

Figura 5.6.1. Gráficos de Mott-Schottky para amostras do aço inoxidável austenítico ABNT NBR ISO 5832-1 em PBS a $37^{\circ} \mathrm{C}$ para amostras não marcadas, imersas por dezessete horas. 
Nos gráficos apresentados nesta seção notam-se diferenças no comportamento dos óxidos de acordo com a condição de acabamento superficial. As amostras correspondentes ao aço sem marcações (Figura 5.6.1) apresentaram inclinações mais elevadas na região de potenciais correspondente ao comportamento de um semicondutor tipo-n (inclinação positiva do gráfico de $1 / C^{2}$ vs. E), faixa que compreende a região de potenciais entre $-0,5 \mathrm{~V}$ e $+0,3 \mathrm{~V}$; e inclinações mais suaves na região de potencias entre $-1,0 \mathrm{~V}$ e $-0,5 \mathrm{~V}$, que correspondem ao comportamento de um semicondutor tipo-p (inclinação negativa do gráfico de $1 / C^{2}$ vs. $E$ ); o que não pode ser ignorado, pois reflete o caráter dúplex do filme protetor, obtido após o período de imersão de dezessete horas, conforme a literatura referenciada anteriormente sobre óxidos protetores formados sobre aços inoxidáveis e suas propriedades eletrônicas utilizando-se a metodologia de Mott-Schottky [15-20, 48].

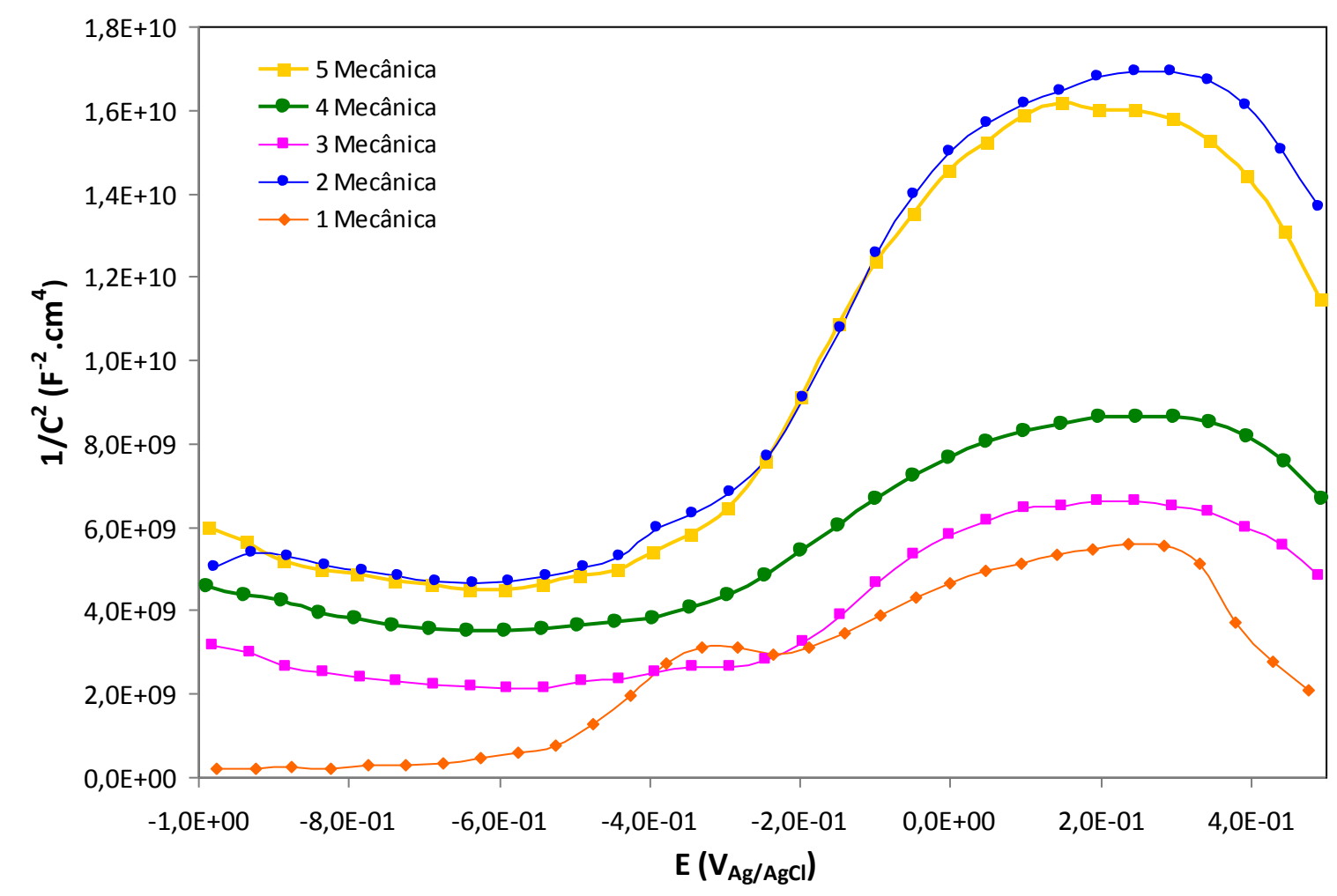

Figura 5.6.2. Gráficos de Mott-Schottky para amostras do aço inoxidável austenítico ABNT NBR

ISO 5832-1 marcadas mecanicamente, imersas por dezessete horas em PBS a $37^{\circ} \mathrm{C}$.

Os gráficos de Mott-Schottky mostrados na Figura 5.6.2 foram obtidos empregando-se a técnica às amostras gravadas mecanicamente, na mesma solução de ensaio, período e temperatura mencionados. Neles verifica-se o 
comportamento dúplex do filme passivo formado sobre o aço. Acima de $-0,5 \mathrm{~V}, 0$ gráfico de $1 / \mathrm{C}^{2}$ vs. $E$ apresenta uma inclinação positiva, correspondente ao comportamento de um semicondutor tipo-n, o que de acordo com Hakiki et al. $[16,19]$ está associado à camada externa de óxidos e hidróxidos de ferro nos filmes passivos em aços inoxidáveis. Abaixo deste potencial, o gráfico muda de inclinação, esta torna-se negativa, típica de um semicondutor tipo-p, e refere-se à camada interna mais enriquecida em óxido de cromo.

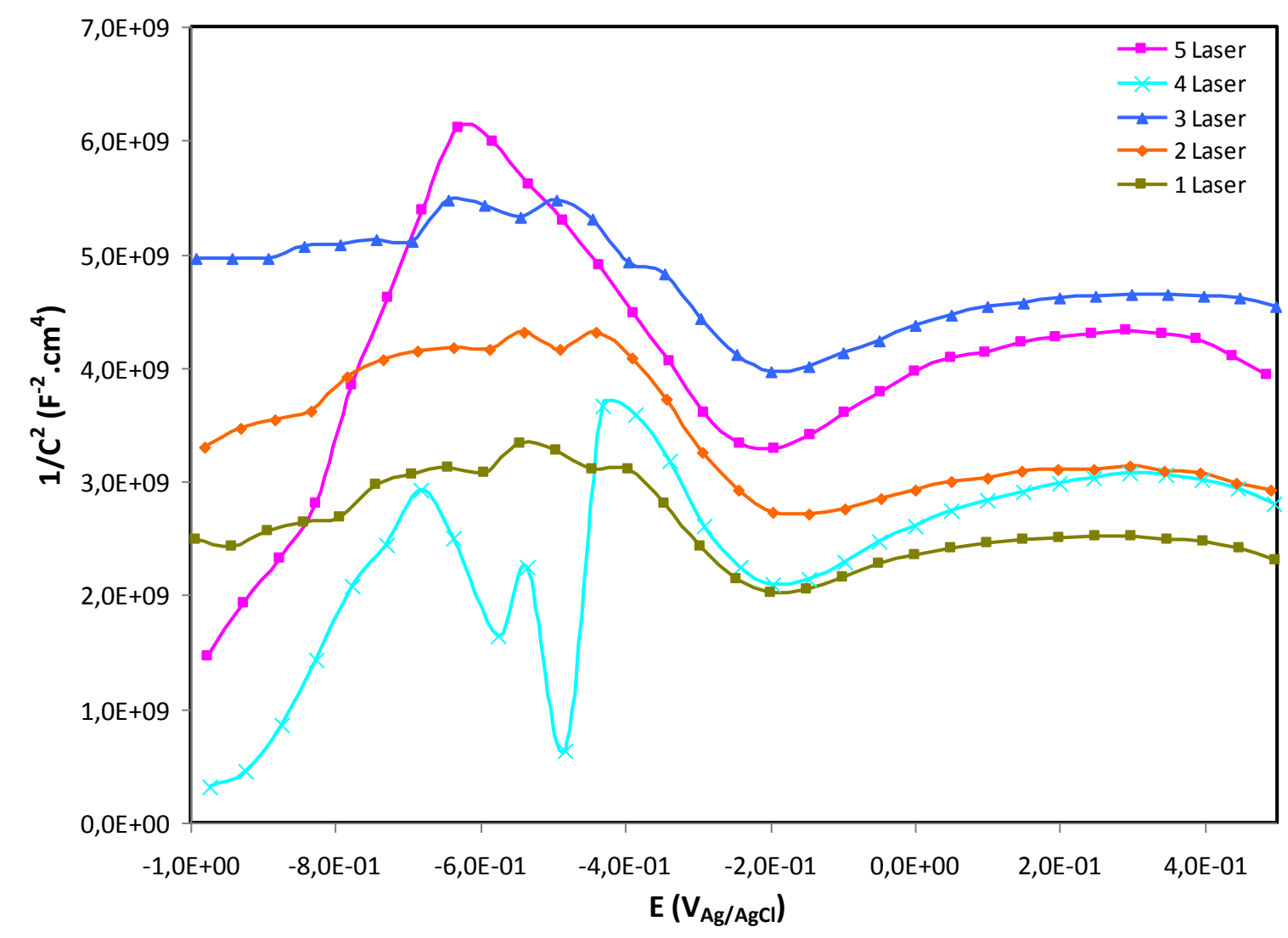

Figura 5.6.3. Gráficos de Mott-Schottky para amostras do aço inoxidável austenítico ABNT NBR ISO 5832-1 marcadas a laser, imersas por dezessete horas em PBS a $37^{\circ} \mathrm{C}$.

A Figura 5.6.3 apresenta gráficos de Mott-Schottky para amostras do aço inoxidável austenítico ABNT NBR ISO 5832-1 marcadas a laser. Nota-se que elas apresentam uma mudança na inclinação quando comparadas às outras condições anteriormente discutidas e, que fica mais claramente evidenciada no gráfico seguinte em que se comparam as condições de acabamento superficial. $O$ aço com este tipo de marcação também exibiu um caráter dúplex, típico de filmes passivos formados sobre aços inoxidáveis, segundo encontrado na literatura [16, 19]; mas mostrou inclinações mais acentuadas em intervalos de potenciais 
diversos dos das outras condições. Na faixa de potenciais compreendida entre $1,0 \mathrm{~V}$ e - $-0,2 \mathrm{~V}$, que corresponde à inclinação negativa das curvas, foram obtidas as maiores inclinações o que se relaciona com o comportamento de um semicondutor tipo-p e está ligado ao óxido de cromo formado na parte mais interna do filme. Já para os potenciais superiores a $-0,2 \mathrm{~V}$ observaram-se inclinações positivas, porém mais suaves, correspondendo à parte mais externa do filme que é basicamente composta por óxidos e hidróxidos de ferro. Este comportamento não é comumente observado, mas vale ressaltar que não foi encontrado na literatura nenhum trabalho que tivesse utilizado esta abordagem para analisar materiais com marcações a laser, sendo, portanto esta uma contribuição original deste estudo.

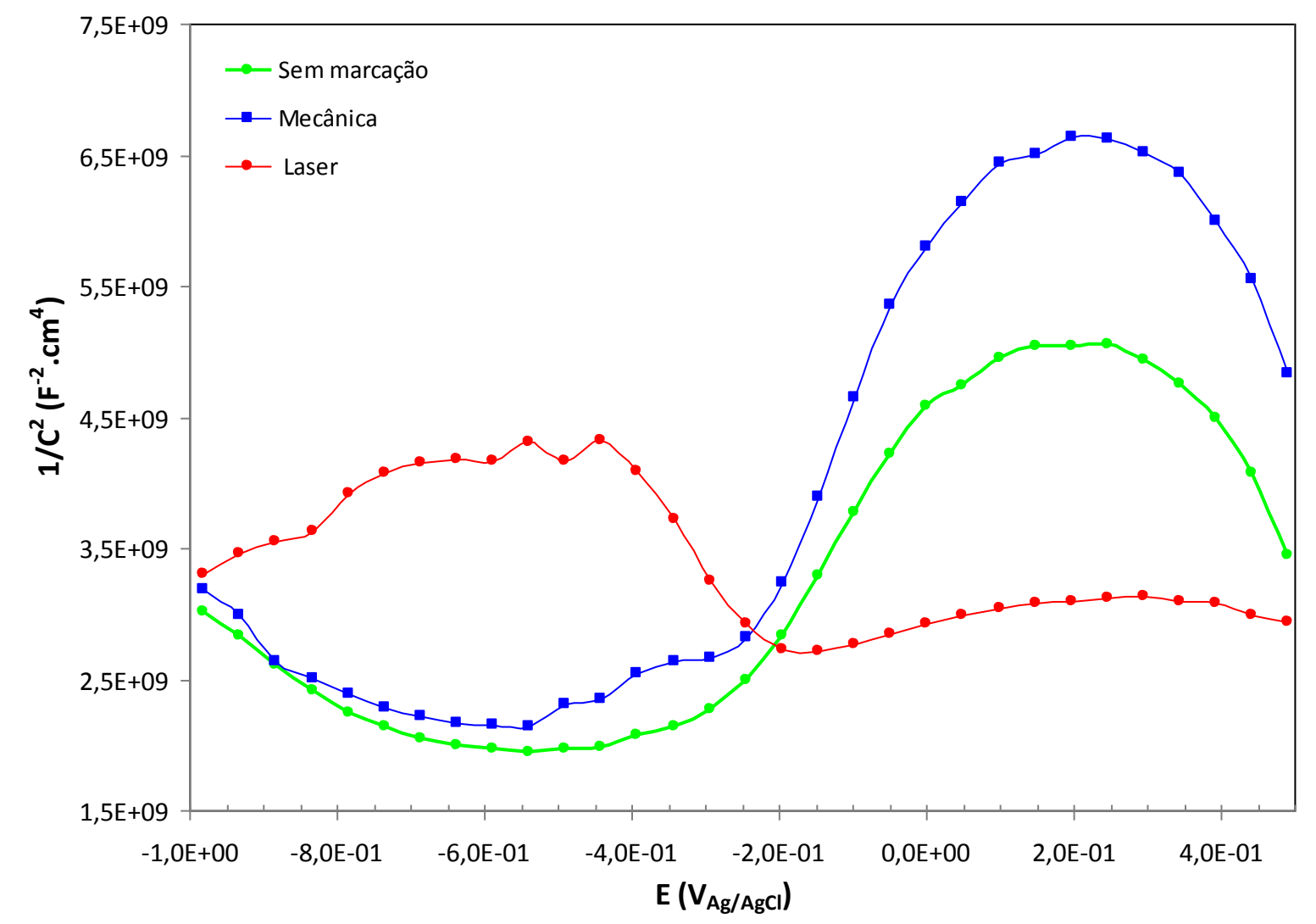

Figura 5.6.4. Gráficos de Mott-Schottky do aço inoxidável austenítico ABNT NBR ISO 5832-1 para amostras nas três condições estudadas, imersas por dezessete horas em PBS a $37^{\circ} \mathrm{C}$.

A partir dos gráficos da Figura 5.6.4 é evidente o efeito causado pelo laser nas propriedades eletrônicas do filme passivo sobre o aço utilizado para este estudo. Nela observa-se que além de mudança na inclinação, também ocorreu deslocamento do potencial de banda plana $\left(E_{b p}\right)$, que como mencionado em 
seções anteriores, é obtido através da extrapolação de $1 / \mathrm{C}^{2}$ para zero. O valor de $E_{b p}$ é utilizado para o cálculo do número de dopantes do filme passivo, sejam eles aceitadores ou doadores de carga, segundo as equações 2 e 3 . Neste trabalho este número não foi utilizado, e sim o valor das inclinações. Os resultados estão mostrados nas Figuras 5.6.5 e 5.6.6.

\section{Densidade de Doadores $\left(\mathrm{cm}^{-3}\right)$}

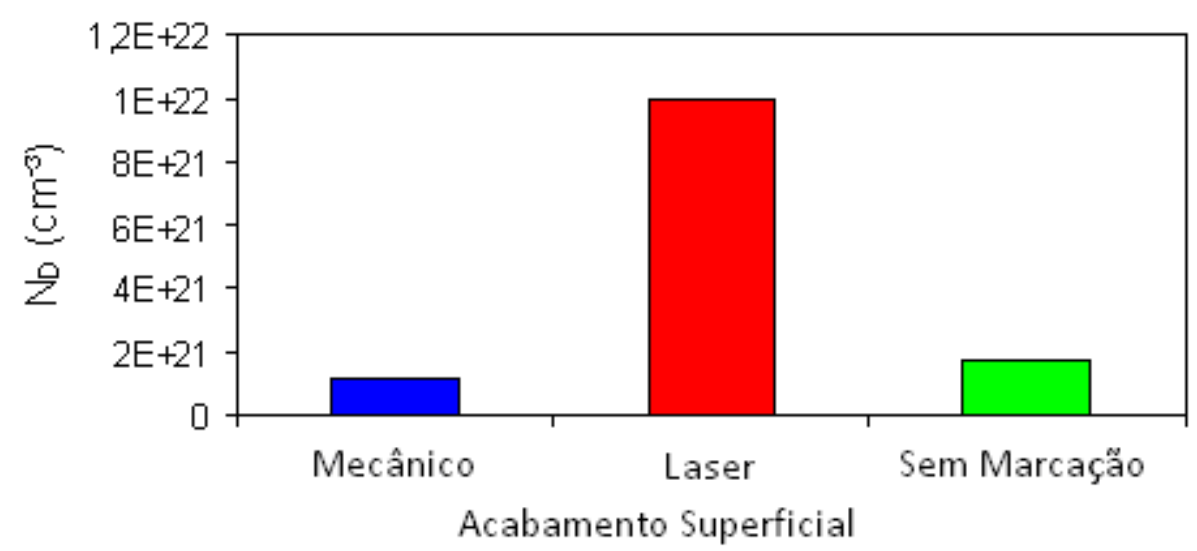

Figura 5.6.5. Valores de doadores de carga no filme passivo, obtidos pelo gráfico de MottSchottky, na região de potenciais referentes à inclinação positiva (comportamento de um semicondutor tipo-n).

\section{Densidade de Aceitadores $\left(\mathrm{cm}^{-3}\right)$}

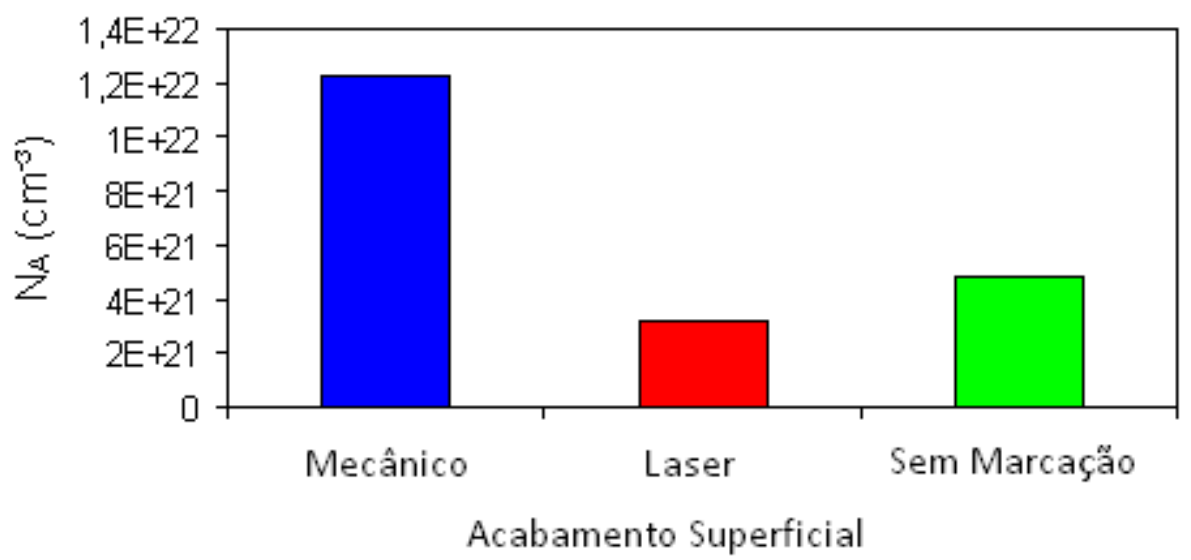

Figura 5.6.6. Valores de aceitadores de carga no filme passivo, obtidos pelo gráfico de MottSchottky, na região de potenciais referentes à inclinação negativa (comportamento de um semicondutor tipo-p). 
As Figuras 5.6 .5 e 5.6.6 mostram as densidades de doadores e aceitadores de cargas, respectivamente, estimadas levando-se em consideração apenas as inclinações posteriores e anteriores ao potencial de banda plana para as três condições testadas. A Figura 5.6.5 mostra que a concentração de doadores de carga, associado a um semicondutor tipo-n é muito maior para as amostras marcadas a laser. Este resultado indica que os defeitos nesta camada são provavelmente responsáveis pela maior susceptibilidade à corrosão localizada observada neste tipo de superfície. Esta tem sido relacionada com a camada mais externa do óxido, rica em níquel e ferro [16-19]. O óxido externo, sendo mais defeituoso, favoreceria o transporte iônico através desta camada do filme, proporcionando o ataque e a quebra da camada interna e o processo de corrosão por pite que se propaga autocataliticamente. Os valores muito baixos de resistência e elevados de capacitância, associados à camada mais externa, conforme indicado pelos resultados de espectroscopia de impedância eletroquímica, mostrados na Tabela 5.2, confirmam esta hipótese.

A camada externa é a responsável pela interação entre filme passivo (externo) e o eletrólito, que possui os íons halogênos. O efeito do laser que causa a deterioração desta camada foi comprovado por SVET. Esta técnica eletroquímica localizada evidenciou as áreas mais anódicas nas regiões marcadas pelo feixe de raios laser, conforme será apresentado posteriormente.

Para um mesmo período de imersão, a concentração de aceitadores de carga no filme passivo das amostras com marcação mecânica, Figura 5.6.6, é maior do que para as demais superfícies. Isto indica que os defeitos mecânicos afetaram significativamente a camada de óxido mais interna, no caso a rica em cromo.

Os valores de densidade de dopantes, neste último caso da ordem de $10^{22}$ $\mathrm{cm}^{-3}$ são superiores à concentração de dopantes encontrada na literatura para este tipo de aço, que é de $10^{20} \mathrm{~cm}^{-3}$ a $10^{21} \mathrm{~cm}^{-3}$. Os resultados de EIE mostrados na Tabela 5.2 também sustentam esta observação, sugerindo uma camada interna mais irregular e heterogênea, com menor resistência em comparação à sem marcações. A densidade de aceitadores no filme sobre a amostra gravada a laser, foi sempre inferior à das amostras sem marcações. 


\subsection{Observação da superfície}

A superfície do aço foi caracterizada metalograficamente, antes e após ensaios de polarização, a fim de se investigar as regiões atacadas e associá-las a características da microestrutura do material. Outro objetivo era o de investigar se - laser acarreta mudanças microestruturais significativas que diminuíssem a resistência à corrosão do aço. Nesta seção estão apresentadas imagens das amostras do aço estudado obtidas empregando-se várias técnicas descritas anteriormente, nas condições: como recebidas, antes e após ensaios de polarização, embutidas em seção transversal, lixadas, polidas e atacadas utilizando-se diferentes reagentes metalográficos. As Figuras 5.7.1 (a) e (b), obtidas por microscopia óptica (MO) realizada no equipamento disponível no Labcorts, mostram o aço estudado com marcações mecânicas, antes e depois do ensaio de polarização, após ataque com água régia, onde é evidenciada microestrutura austenítica.

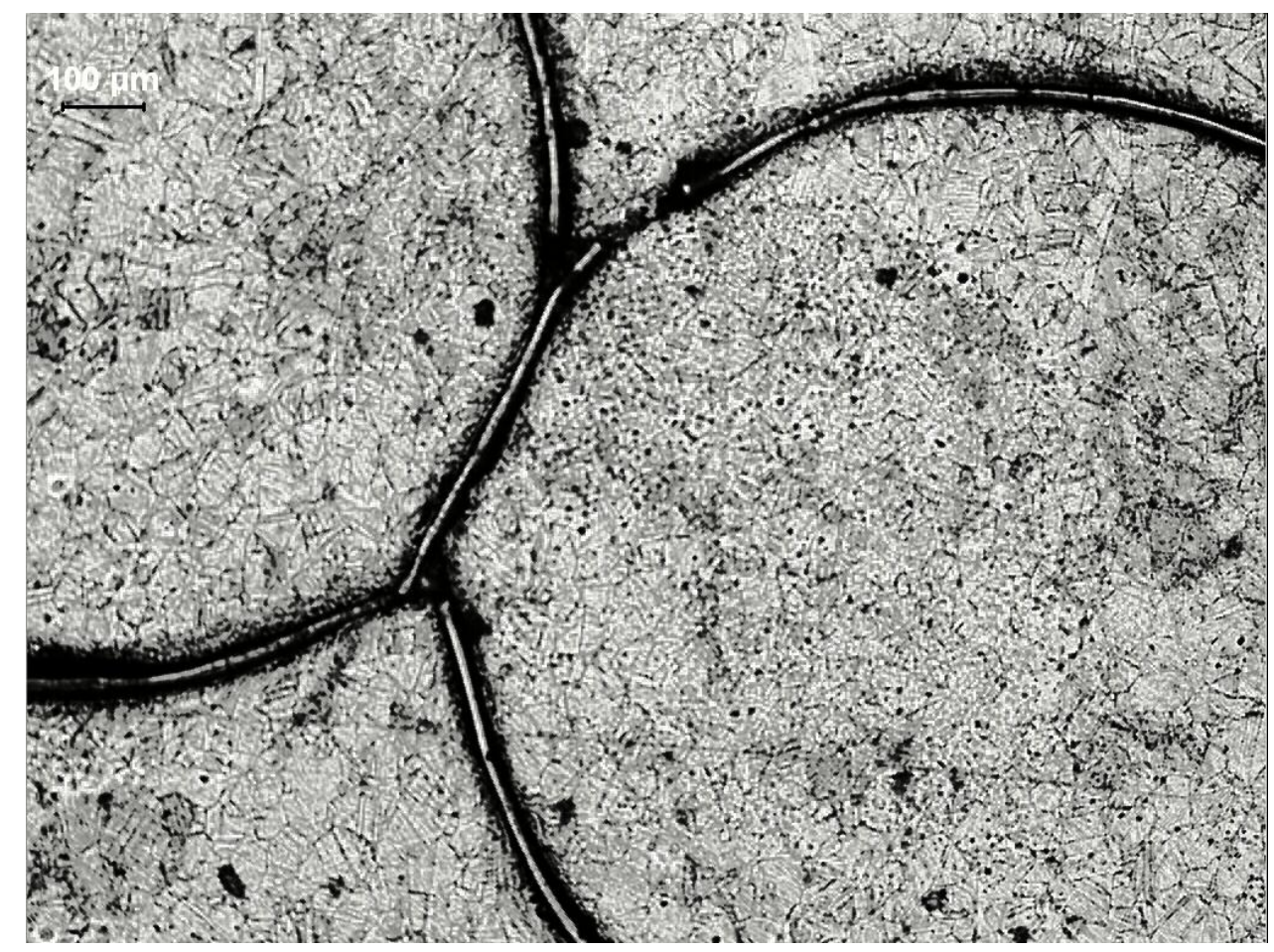

(a) 


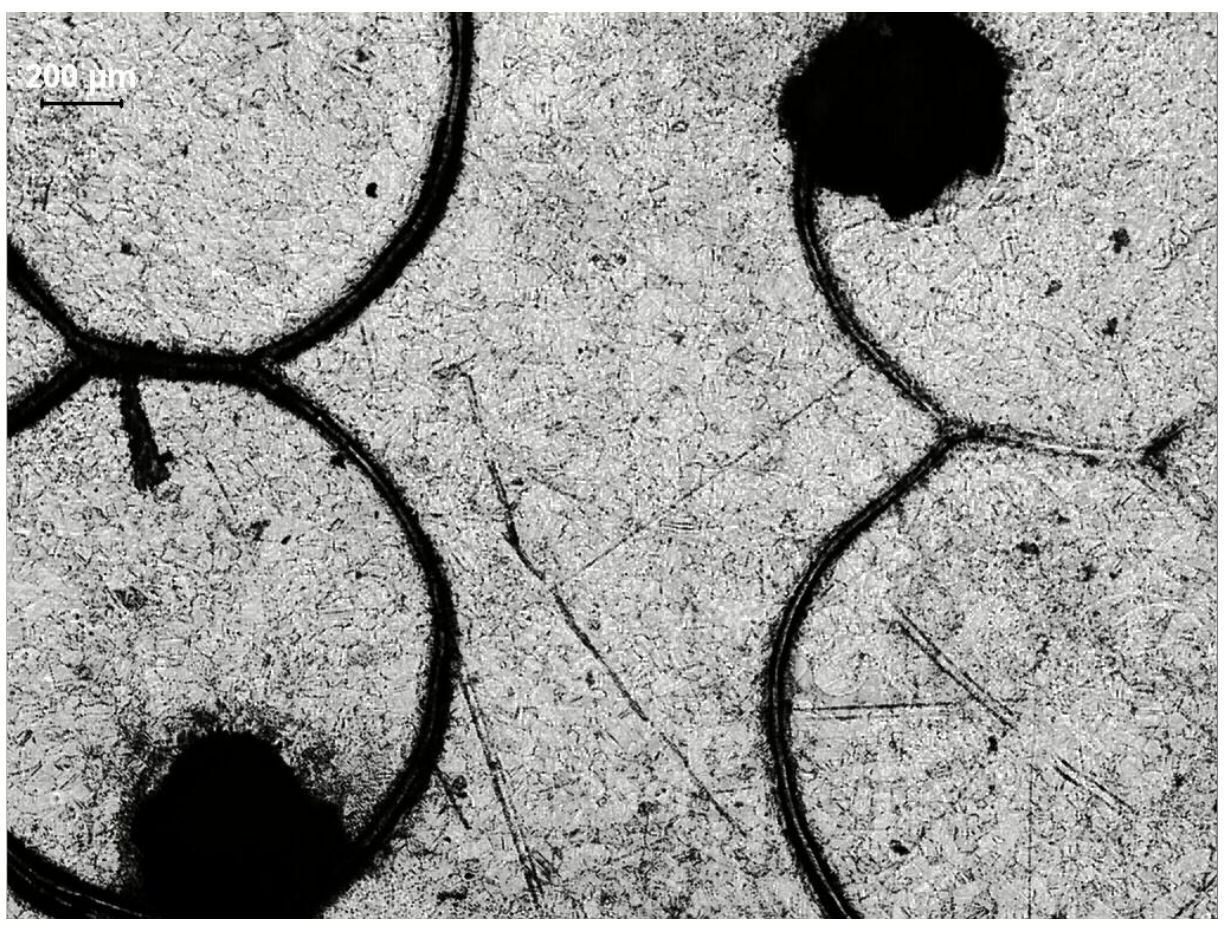

(b)

Figura 5.7.1. Microscopia óptica do aço inoxidável ABNT NBR ISO 5832-1 com marcação mecânica, (a) antes do ensaio de polarização cíclica, (b) após o ensaio. Ataque via água régia.

Nas Figuras 5.7.2 (a) e (b) estão apresentadas imagens de microscopia óptica para amostras marcadas a laser e atacadas com água régia, onde se observa a microestrutura austenítica com grande número de maclas, que já estavam no material de partida.

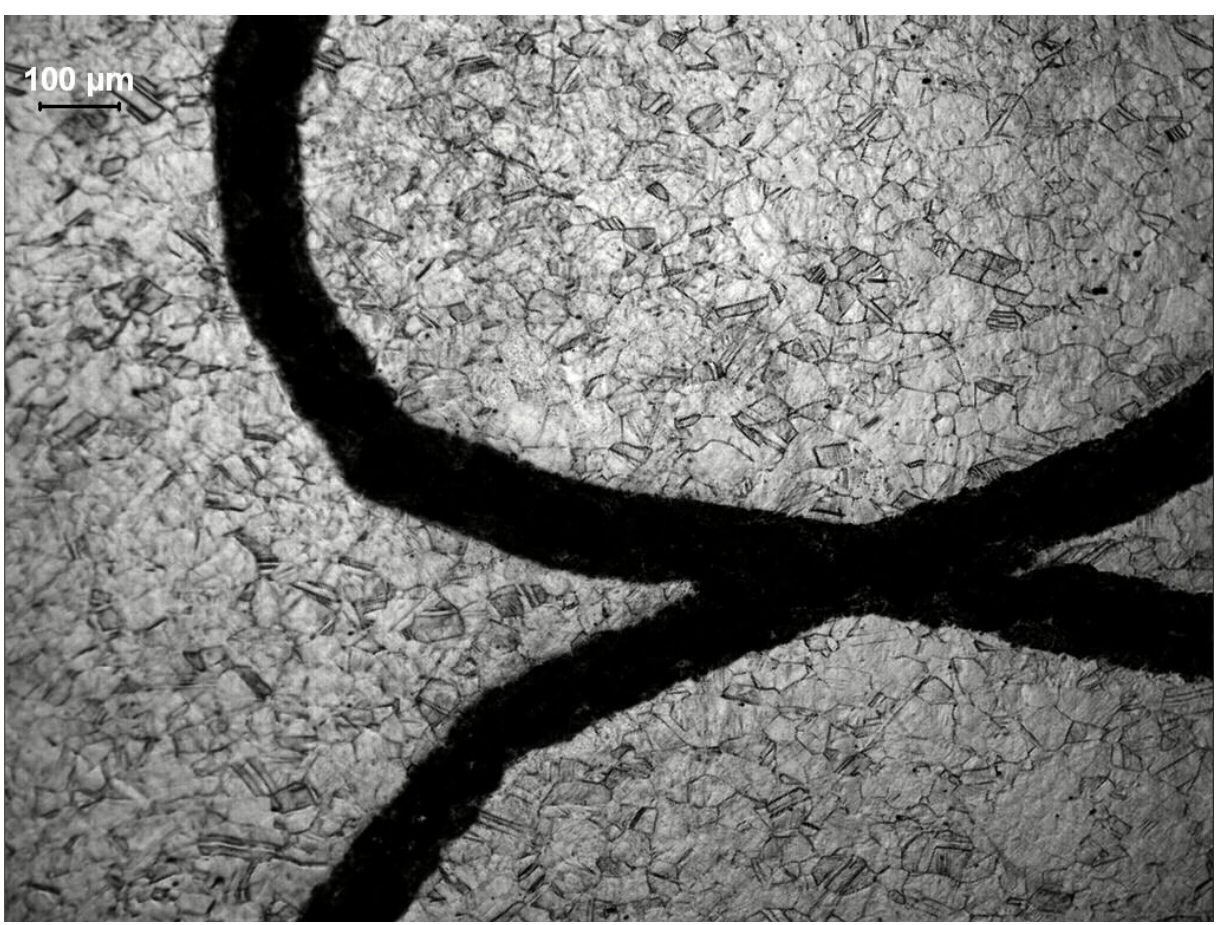

(a) 


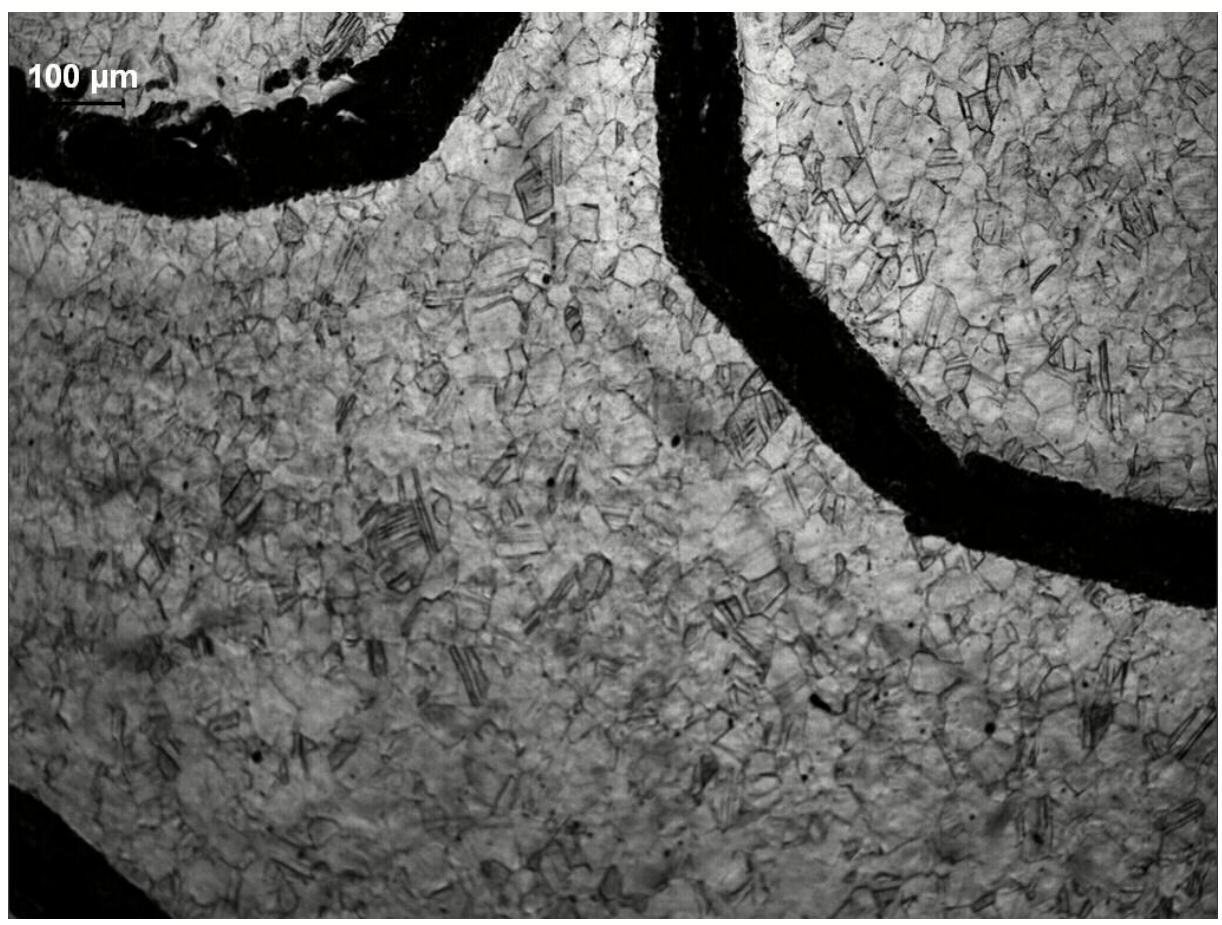

(b)

Figura 5.7.2. Microscopia óptica do aço inoxidável ABNT NBR ISO 5832-1 com marcação a laser, atacada via água régia, antes do ensaio de polarização.

A superfície marcada pelo laser apresenta rugosidade típica de estruturas brutas de fusão, como pode ser observado nas micrografias obtidas por microscopia eletrônica de varredura (MEV), conforme as Figuras 5.7.3 (a) e (b) apresentam.

As Figuras 5.7.4 (a) e (b) mostram que a região central do algarismo oito é a mais afetada, por ser um local onde o feixe de raios laser incide duas vezes, tornando a região duplamente afetada pelo calor; o que pôde ser verificado após a análise de grande número de amostras polarizadas nas duas condições de marcação, pelo fato das amostras marcadas a laser apresentarem sempre maior quantidade de pites nesta região, enquanto que nas marcadas pela técnica mecânica os pites foram encontrados posicionados aleatoriamente nas regiões adjacentes às gravações, como pode ser comparado observando-se a Figura 5.7 .5 . 


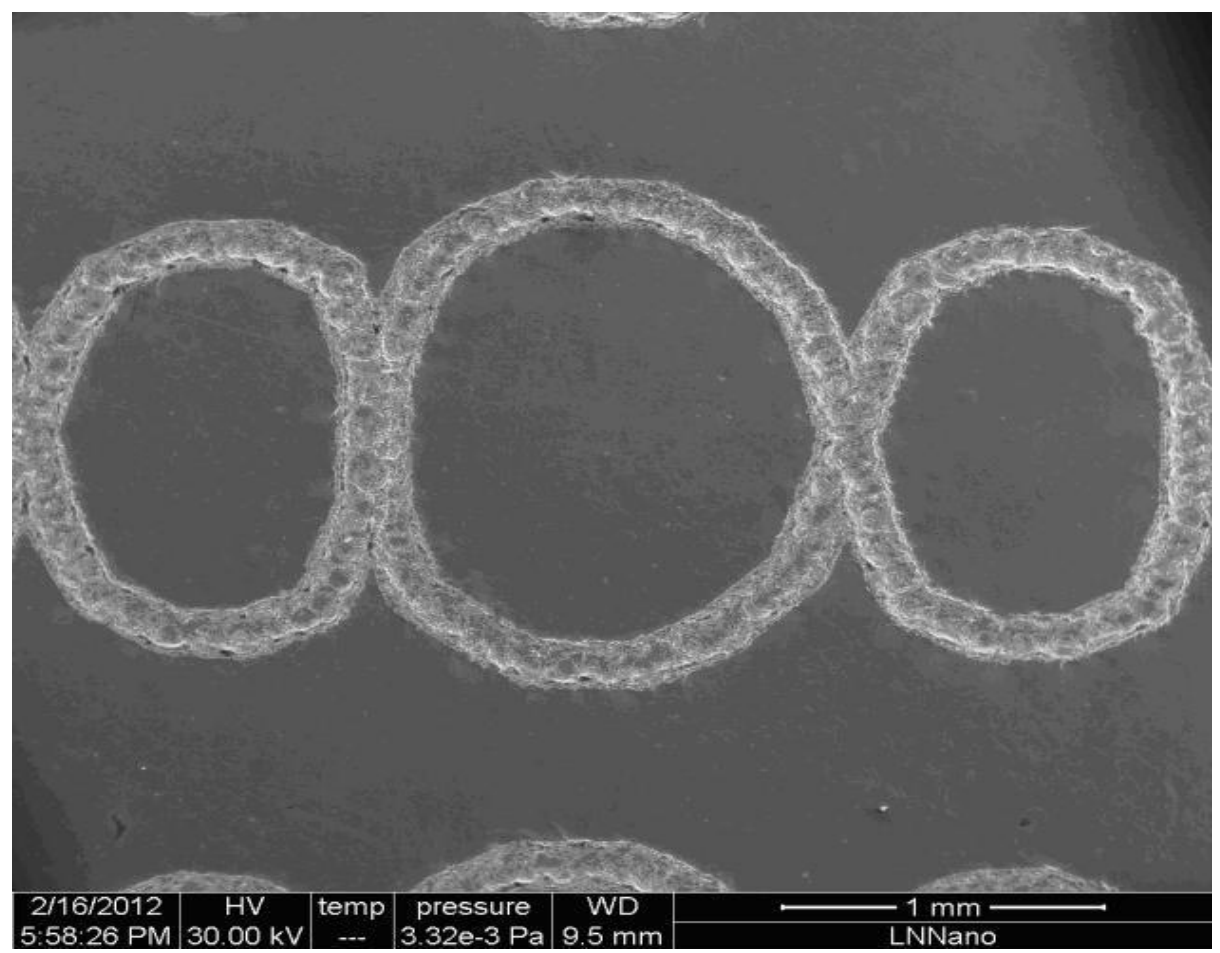

Figura 5.7.3 (a). Microscopia eletrônica de varredura do aço inoxidável ABNT NBR ISO 5832-1 com marcação a laser, antes do ensaio de polarização, sem ataque.

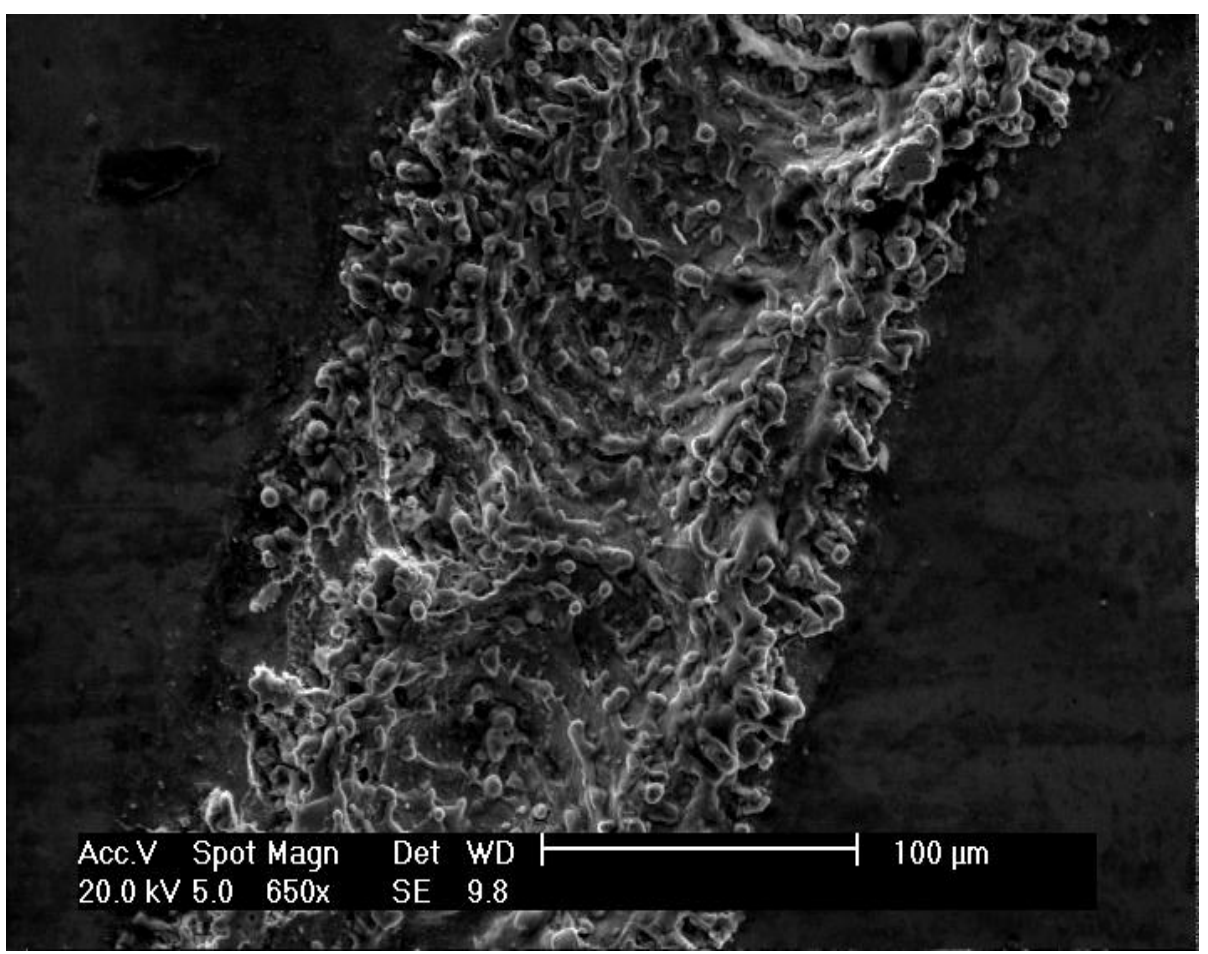

Figura 5.7.3.(b) Microscopia eletrônica de varredura do aço inoxidável ABNT NBR ISO 5832-1 com marcação a laser, antes do ensaio de polarização, sem ataque. A ampliação mostra uma estrutura típica de bruta de fusão. 


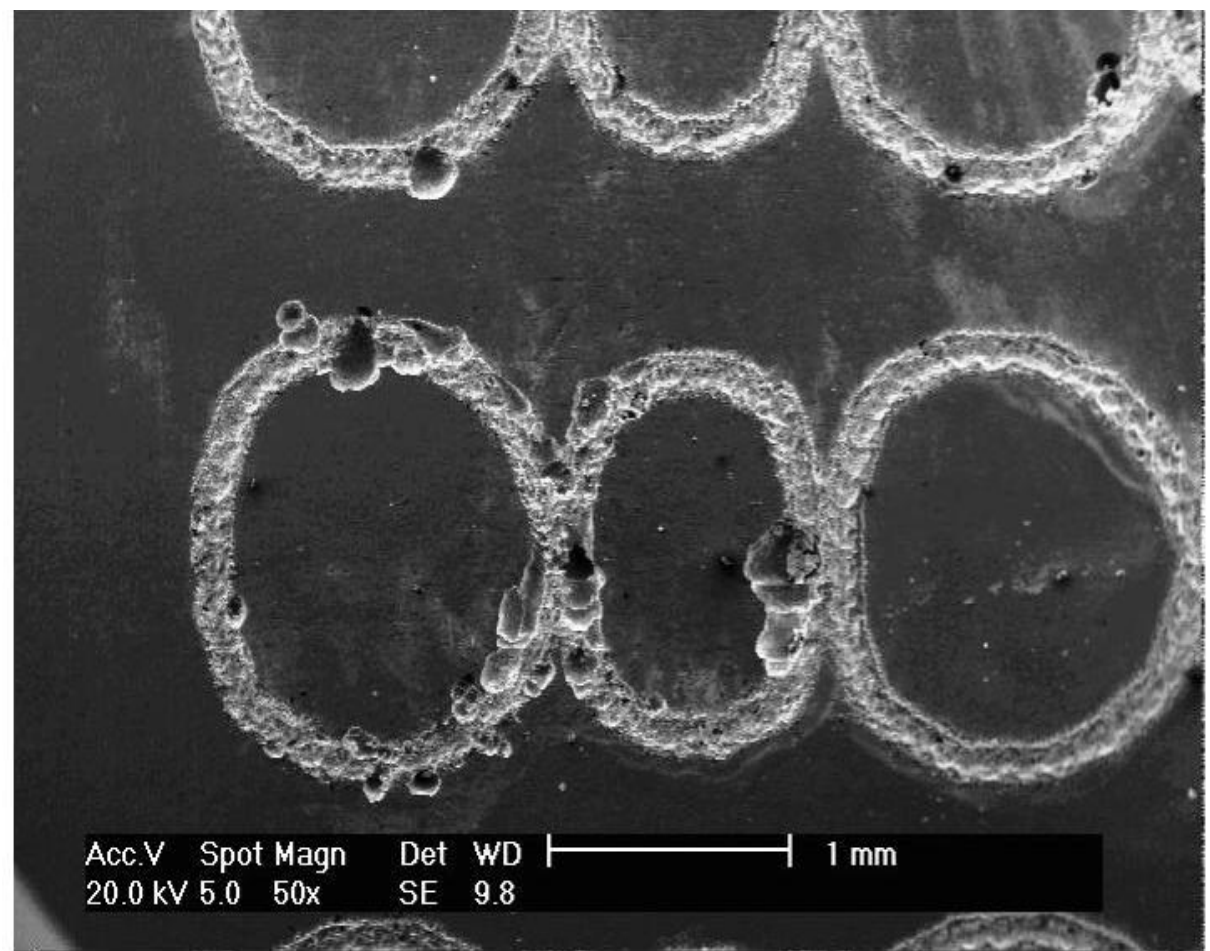

Figura 5.7.4.(a) Microscopia eletrônica de varredura do aço inoxidável ABNT NBR ISO 5832-1 com marcação a laser, após o ensaio de polarização cíclica.

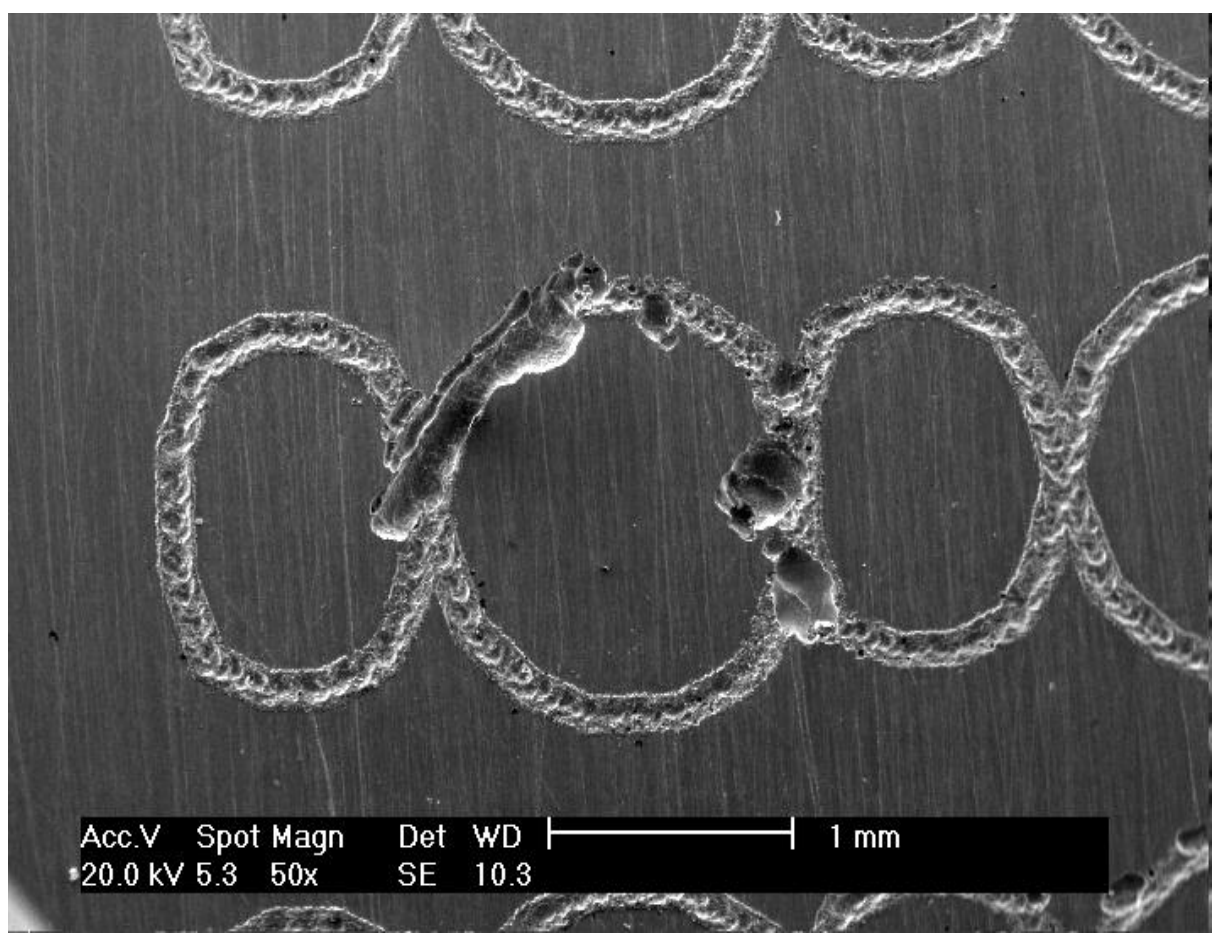

Figura 5.7.4.(b) Microscopia eletrônica de varredura do aço inoxidável ABNT NBR ISO 5832-1 com marcação a laser, após o ensaio de polarização cíclica, onde há concentração da corrosão na região central da marcação. 


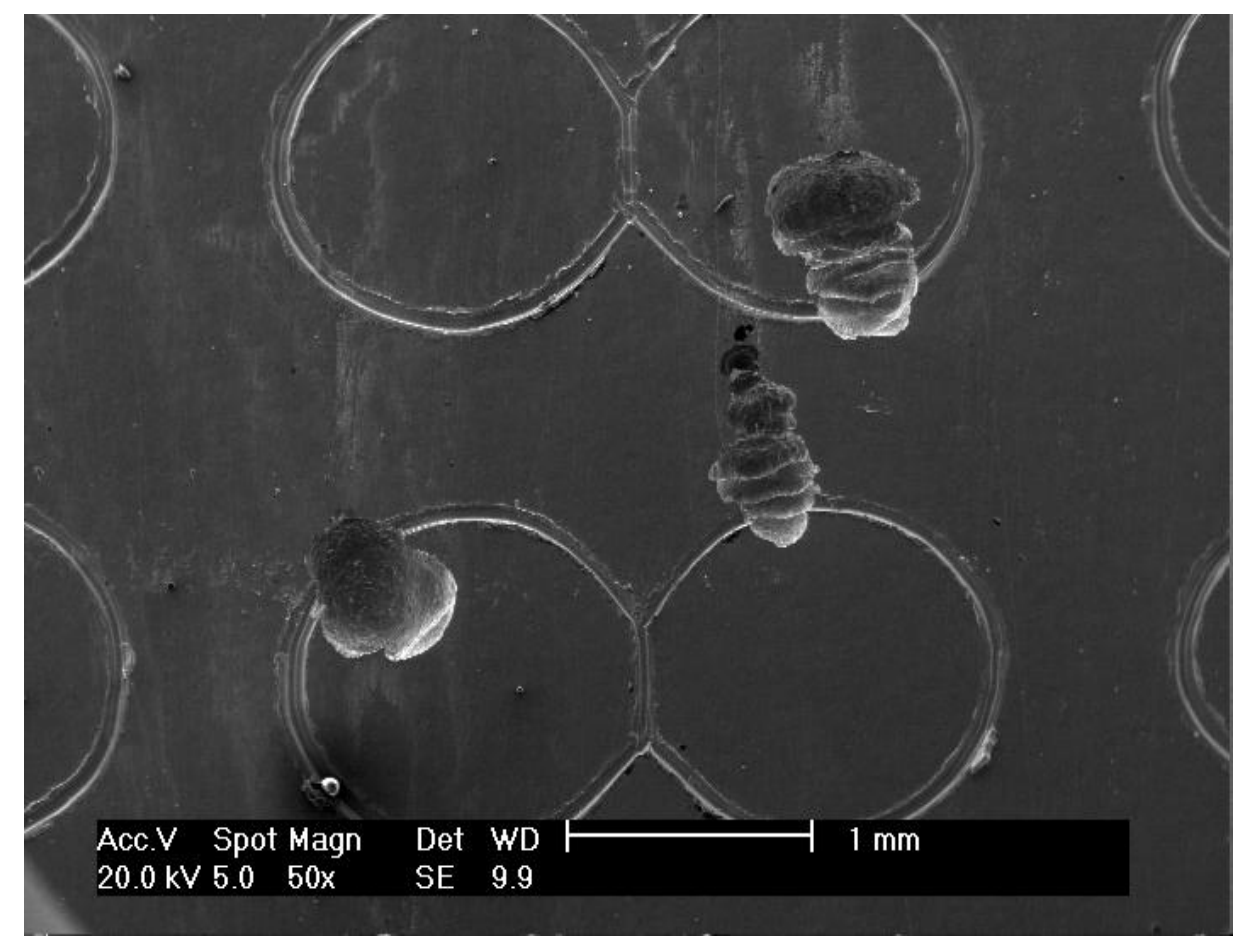

Figura 5.7.5. Microscopia eletrônica de varredura do aço inoxidável ABNT NBR ISO 5832-1 com marcação mecânica, após o ensaio de polarização cíclica, onde não há concentração de pites na região central da marcação.

Devido ao fato das amostras marcadas via raios laser apresentarem os menores valores de resistência à corrosão, foram realizadas análises de espectroscopia de energia dispersiva (EDS) das amostras após os ensaios de polarização cíclica, a fim de se verificar se o laser produzira algum efeito deletério na composição química do aço, comparando-se com as amostras sem marcações bem como as mecanicamente marcadas. Os resultados obtidos não foram significativos, portanto, na Tabela 5.4 abaixo estão apresentados somente resultados de EDS para a amostra marcada a laser nas regiões (A): substrato, (B): anel da marcação e $(C)$ : pite na região central da marcação do algarismo oito da Figura 5.7.6. 


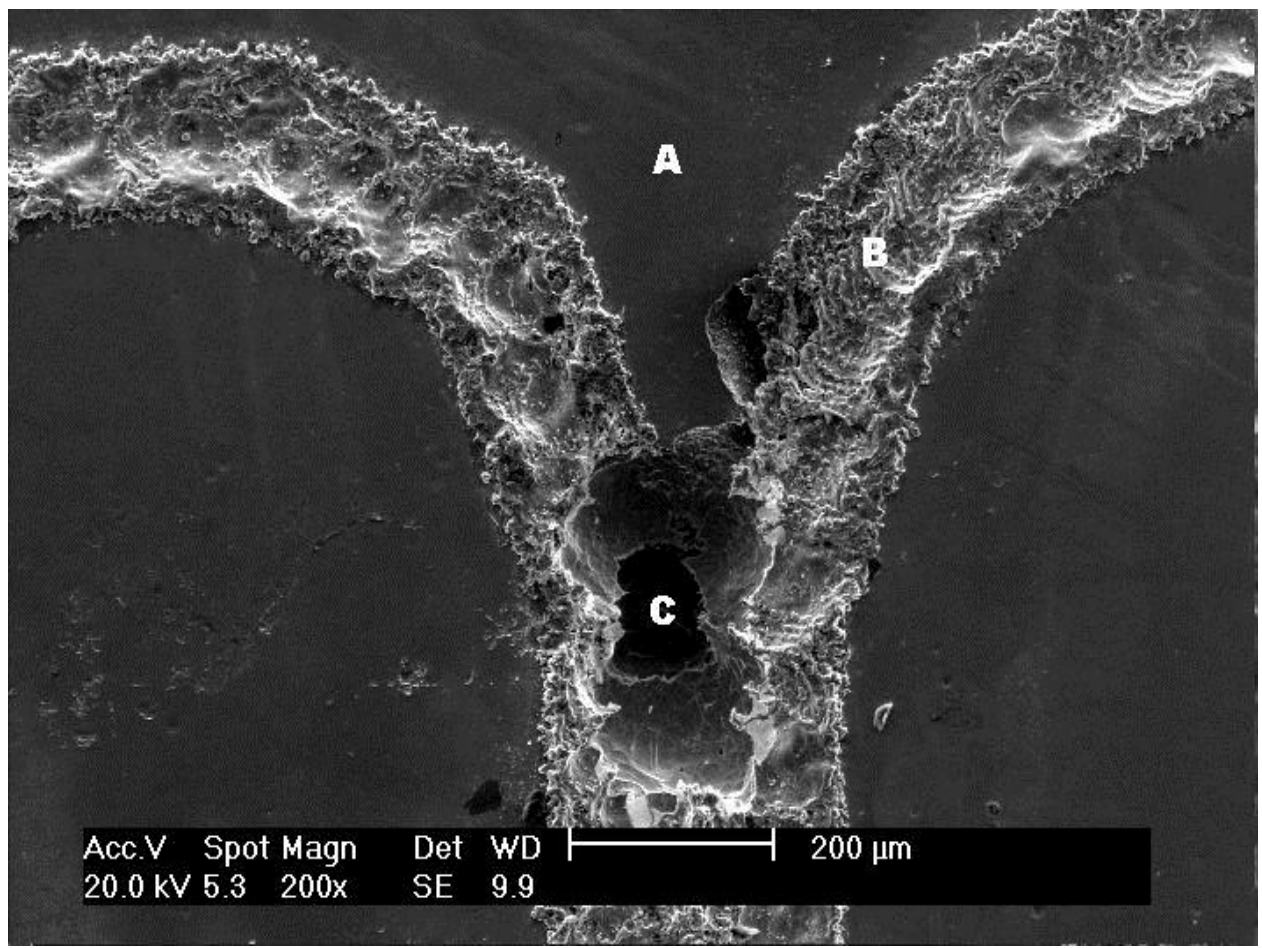

Figura 5.7.6. Microscopia eletrônica de varredura do aço inoxidável ABNT NBR ISO 5832-1 com marcação a laser, após do ensaio de polarização cíclica, onde $(A)$ : substrato, $(B)$ : região da marcação e $(C)$ : pite na região central da marcação do algarismo oito.

Tabela 5.4. Composição química obtida por EDS nas regiões A, B e C da Figura 5.7.6.

\begin{tabular}{ccccc}
\hline RegiãolElementos & $\mathrm{Fe}$ & $\mathrm{Cr}$ & $\mathrm{Ni}$ & $\mathrm{Mo}$ \\
\hline $\mathrm{A}$ & 63,70 & 18,37 & 14,94 & 2,99 \\
\hline $\mathrm{B}$ & 63,39 & 18,99 & 14,84 & 2,78 \\
\hline $\mathrm{C}$ & 64,91 & 19,51 & 13,65 & 1,93 \\
\hline
\end{tabular}

A análise de espectroscopia de energia dispersiva (EDS) não apresentou variações muito significativas da composição química do aço nas regiões assinaladas na Figura 5.7.6. Estes resultados mostram que este tipo de análise não é sensível o suficiente para permitir diagnosticar alterações na composição química causadas pelo laser e justificar o comportamento das amostras sujeitas a este tipo de marcação.

A alternativa encontrada foi a utilização de análises de EDS-QUANTA realizadas no SEM-FEG. Este equipamento proporcionou a aquisição de imagens com altíssima resolução e resultados de análises químicas (EDS), das amostras do aço marcado a laser, diferentes dos obtidos utilizando-se o MEV convencional. Os resultados obtidos apresentaram alteração da composição química do aço 
marcado a laser principalmente nas regiões centrais do algarismo oito, ou seja, onde o laser incidiu duas vezes, afetando a região duplamente. Estes resultados serão mostrados a seguir, na seção 5.8 .

Utilizando-se ainda a técnica de microscopia eletrônica de varredura (MEV) foi possível observar amostras do aço estudado que de forma não intencional, mas devido ao arranjo experimental, apresentaram corrosão por fresta, cujo estudo não é objetivo deste trabalho. Algumas imagens são apresentadas a seguir, nelas se comprova a influência do laser sobre a superfície do aço inoxidável. A fresta inicia-se nas junções do algarismo oito, ou seja, onde o laser incidiu duplamente.

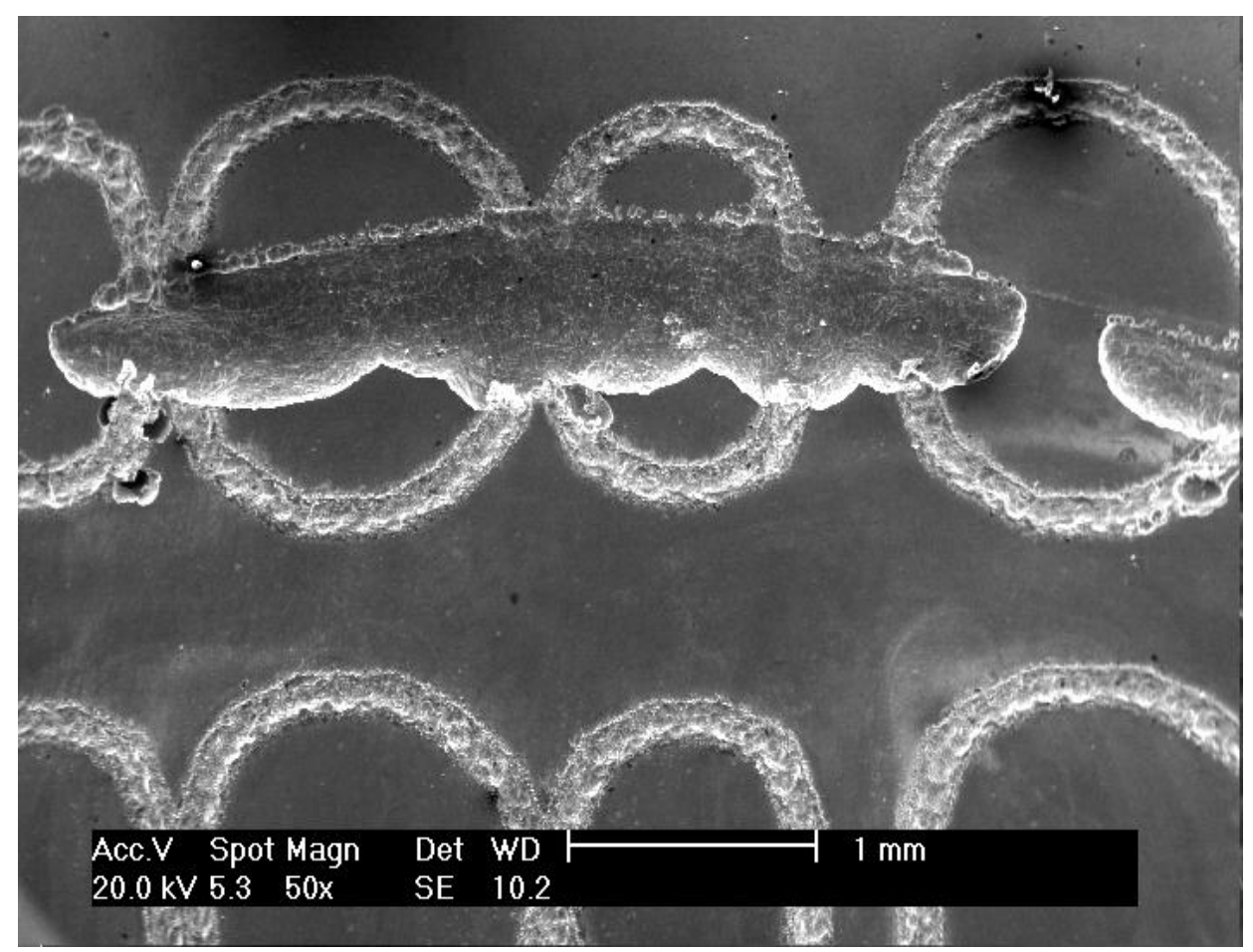

Figura 5.7.7. Microscopia eletrônica de varredura mostrando região de fresta formada na região central da gravação a laser do número oito em uma amostra do aço inoxidável ABNT NBR ISO 5832-1, sem ataque metalográfico.

A Figura 5.7.8 é uma ampliação da Figura 5.7.7, onde é mostrada a fresta formada entre o "o-ring" de borracha utilizado na célula plana para os ensaios eletroquímicos e a região central da marcação via raios laser. Nesta região, caracterizada por apresentar aeração diferencial, justifica-se o surgimento da fresta devido à rugosidade produzida pelo laser, que funde o material, empurrando-o para as zonas adjacentes, gerando regiões com diferentes alturas 
e profundidades em relação ao substrato; determinando o acesso dos íons de oxigênio. Conforme já está firmemente estabelecido na literatura, esta situação causa uma localizada e acentuada queda no $\mathrm{pH}$, tornando a região mais ácida do que em outras áreas e contribuindo para o mecanismo de corrosão. Na Figura 5.7.8 observa-se também que as condições encontradas na região da fresta foram tão agressivas ao material que foi possível observar a microestrutura do aço via MEV, após o ensaio de polarização cíclica, sem a necessidade de ataque metalográfico prévio e, constatou-se que alguns grãos haviam sido arrancados.

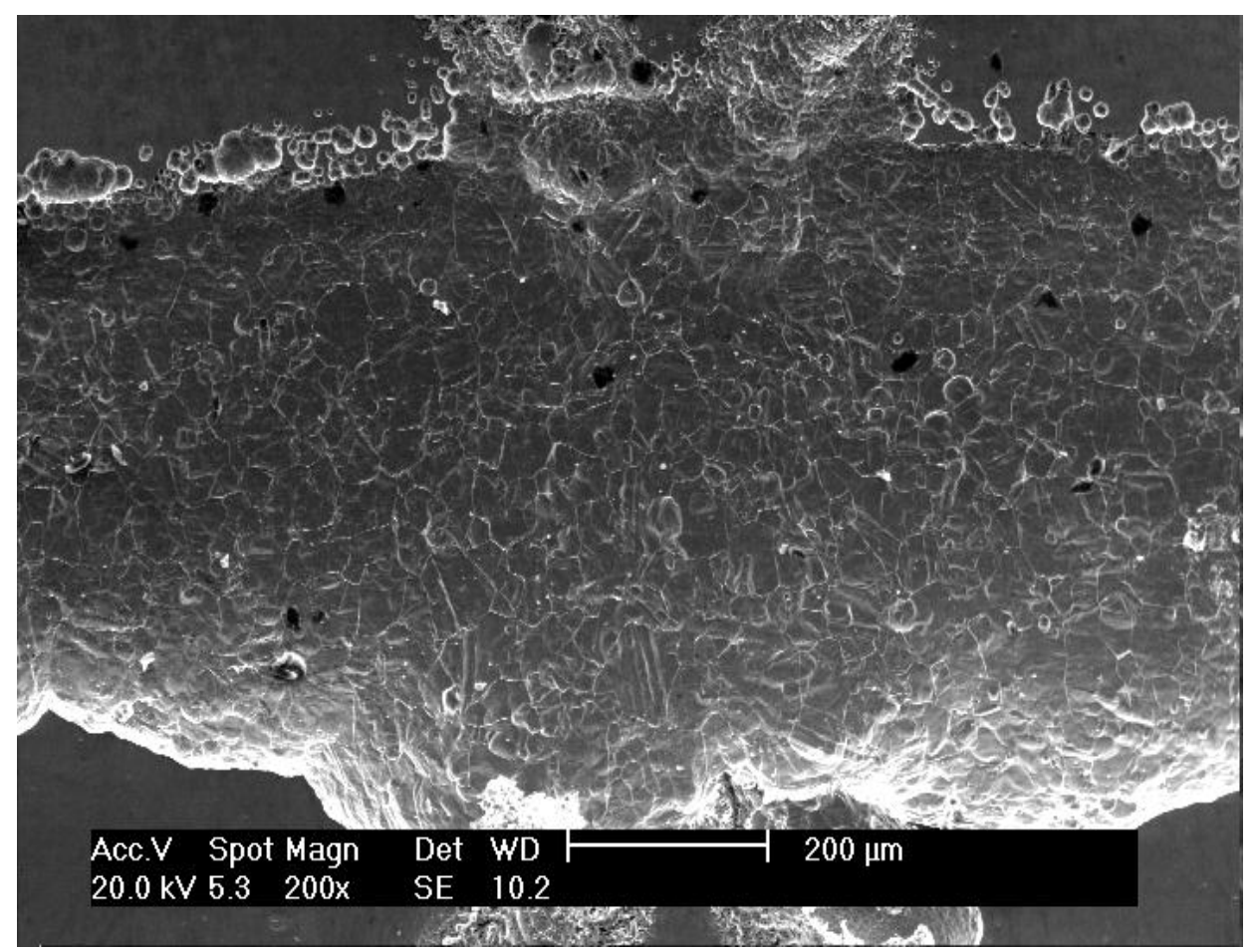

Figura 5.7.8. Ampliação da Figura 5.7.7. Região de fresta onde se evidencia a microestrutura austenítica do aço inoxidável e, apresenta grãos arrancados. Após polarização cíclica, sem ataque metalográfico.

\subsection{Características produzidas pelo laser na superfície do aço inoxidável}

As análises de EDS foram extraídas pontualmente, em linha e em área nas regiões sem marcações e com marcações a laser onde houve incidência do feixe de raios laser uma única vez e duas vezes, como está apresentado nas figuras e nos espectros seguintes. Existiram alterações significativas relacionadas aos elementos cromo, níquel, molibdênio e manganês, que podem ser observadas 
comparando-se os espectros de EDS e as tabelas de composição química para as diferentes regiões analisadas, que se encontram selecionadas nas Figuras 5.8.1 a 5.8.5.

Também foram encontradas imagens nas amostras com marcação a laser e atacadas via água régia, classificadas como "etch pit", que são características de materiais com elevada densidade de discordâncias. Segundo a literatura [51, 52] estas microestruturas aparecem onde as discordâncias apontam na superfície do material metálico, ou seja, não trata-se de um mecanismo eletroquímico. Os "etch pits" apresentam formas geométricas bem definidas devido ao ataque preferencial em algumas direções cristalográficas, o que permite determinar-se a orientação cristalográfica dos grãos. No caso do aço estudado, elas surgiram na região limítrofe entre o substrato e a marcação a laser, isto é, na zona termicamente afetada. As imagens de "etch pit" estão apresentadas nas Figuras 5.8.6 a 5.8.8, seguintes.
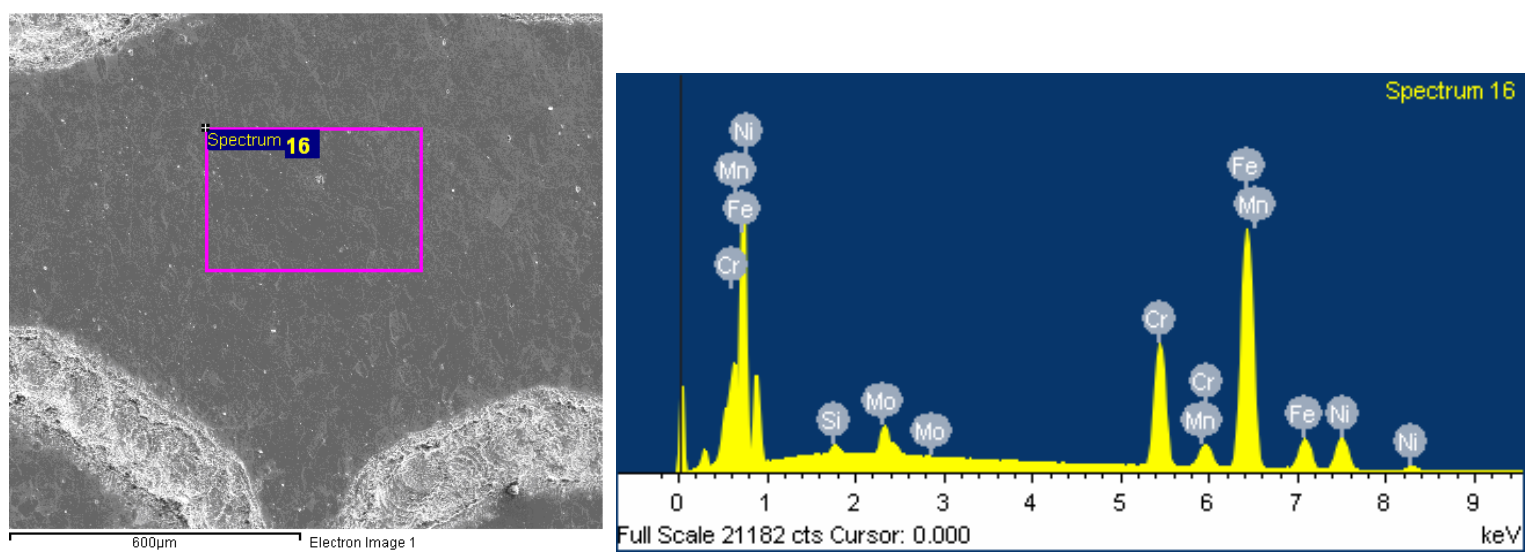

Figura 5.8.1. Espectro de EDS para a região da matriz, cuja área selecionada está identificada pelo retângulo.

Tabela 5.5. Composição química obtida por EDS na região da Figura 5.8.1.

\begin{tabular}{c|cc}
\hline Elemento & \% Massa & \% Atômica \\
\hline & & \\
\hline Si K & 0,41 & 0,83 \\
\hline $\mathrm{Cr} \mathrm{K}$ & 18,27 & 19,70 \\
\hline $\mathrm{Mn} \mathrm{K}$ & 1,92 & 1,96 \\
\hline $\mathrm{Fe} \mathrm{K}$ & 61,47 & 61,68 \\
\hline $\mathrm{Ni} \mathrm{K}$ & 14,48 & 13,82 \\
\hline $\mathrm{Mo} \mathrm{L}$ & 3,44 & 2,01 \\
\hline & \multicolumn{2}{c}{} \\
\hline Total & 100,00 & \\
\hline
\end{tabular}


A Figura 5.8.2 mostra a análise semiquantitativa dos elementos químicos obtidos na região de encontro de duas marcações produzidas pelo feixe de raios laser.
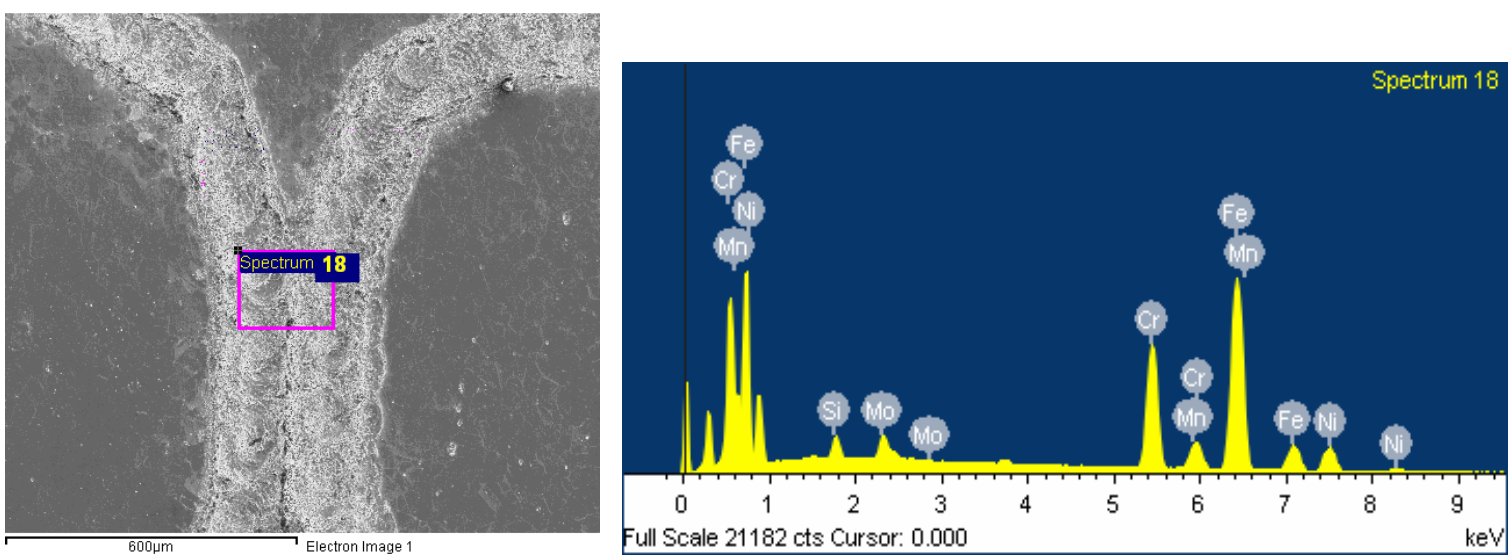

Figura 5.8.2. Espectro de EDS para a região de encontro do feixe de laser, cuja área selecionada está identificada pelo retângulo.

Tabela 5.6. Composição química obtida por EDS na região da Figura 5.8.2.

\begin{tabular}{c|cc}
\hline Elemento & \% Massa & \% Atômica \\
\hline & \multicolumn{2}{|}{} \\
\hline Si K & 1,10 & 2,18 \\
\hline Cr K & 21,62 & 23,05 \\
\hline $\mathrm{Mn} \mathrm{K}$ & 3,02 & 3,05 \\
\hline $\mathrm{Fe} \mathrm{K}$ & 58,37 & 57,94 \\
\hline $\mathrm{Ni} \mathrm{K}$ & 12,58 & 11,88 \\
\hline $\mathrm{Mo} \mathrm{L}$ & 3,30 & 1,91 \\
\hline & \multicolumn{2}{c}{} \\
\hline Total & 100,00 & \\
\hline
\end{tabular}



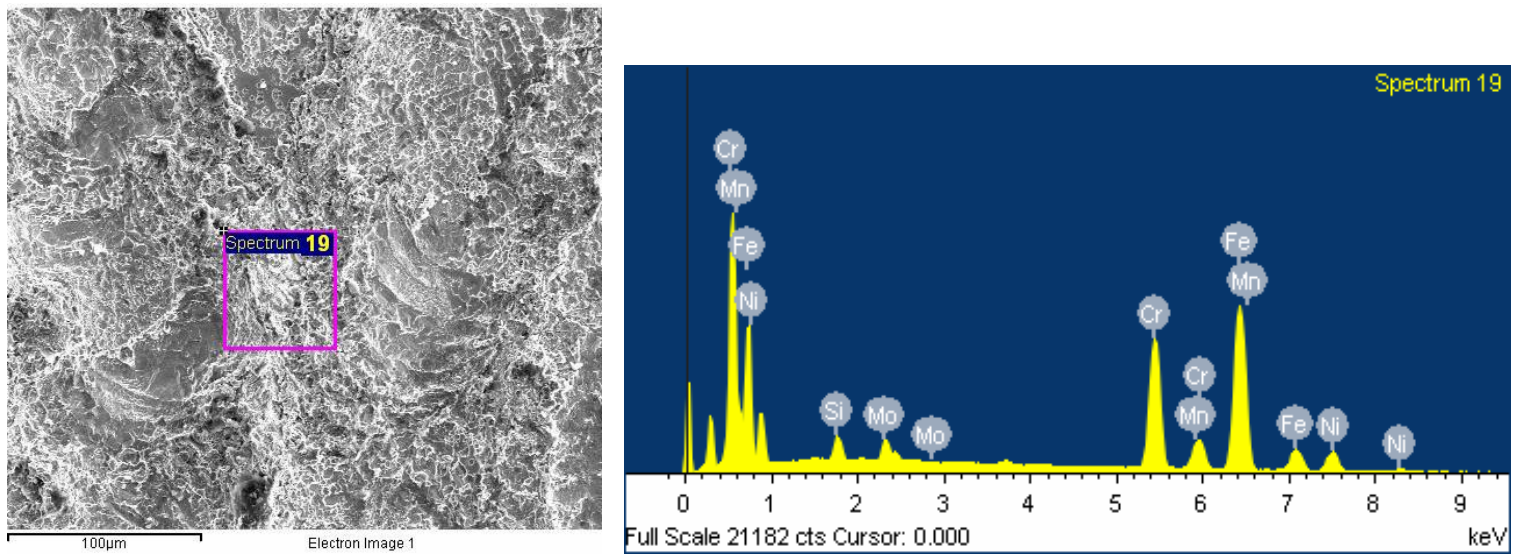

Figura 5.8.3. Espectro de EDS para a região fundida, cuja área selecionada está identificada pelo retângulo e corresponde à região fundida duas vezes.

Tabela 5.7. Composição química obtida por EDS na região da Figura 5.8.3.

\begin{tabular}{c|cc}
\hline Elemento & \% Massa & \% Atômica \\
\hline & \multicolumn{2}{|}{} \\
\hline Si K & 1,30 & 2,54 \\
\hline $\mathrm{Cr} \mathrm{K}$ & 25,18 & 26,68 \\
\hline $\mathrm{Mn} \mathrm{K}$ & 4,34 & 4,35 \\
\hline $\mathrm{Fe} \mathrm{K}$ & 54,84 & 54,10 \\
\hline $\mathrm{Ni} \mathrm{K}$ & 11,22 & 10,53 \\
\hline $\mathrm{Mo} \mathrm{L}$ & 3,12 & 1,79 \\
\hline & \multicolumn{2}{c}{} \\
\hline Total & 100,00 \\
\hline \multicolumn{2}{|c}{}
\end{tabular}

Como pode ser notado pelas figuras apresentadas correlacionando-as com as tabelas de composição química, o elemento cromo foi o que apresentou maior variação em sua composição química, o que sugere que a marcação via raios laser gerou zonas empobrecidas e zonas enriquecidas deste elemento em comparação com a matriz. Nota-se, contudo, que há uma queda nos valores de níquel.

As Figuras 5.8.4 e 5.8.5, a seguir, são exemplos deste comportamento que foi observado unicamente nas regiões onde a fusão do aço inoxidável ocorreu duas vezes e, que correspondem aos sítios com as maiores quantidades de pites de corrosão obtidos após os ensaios de polarização cíclica, como já fora apresentado e discutido. Abaixo destas figuras estão as tabelas com as composições químicas extraídas das regiões identificadas, nas mesmas. 


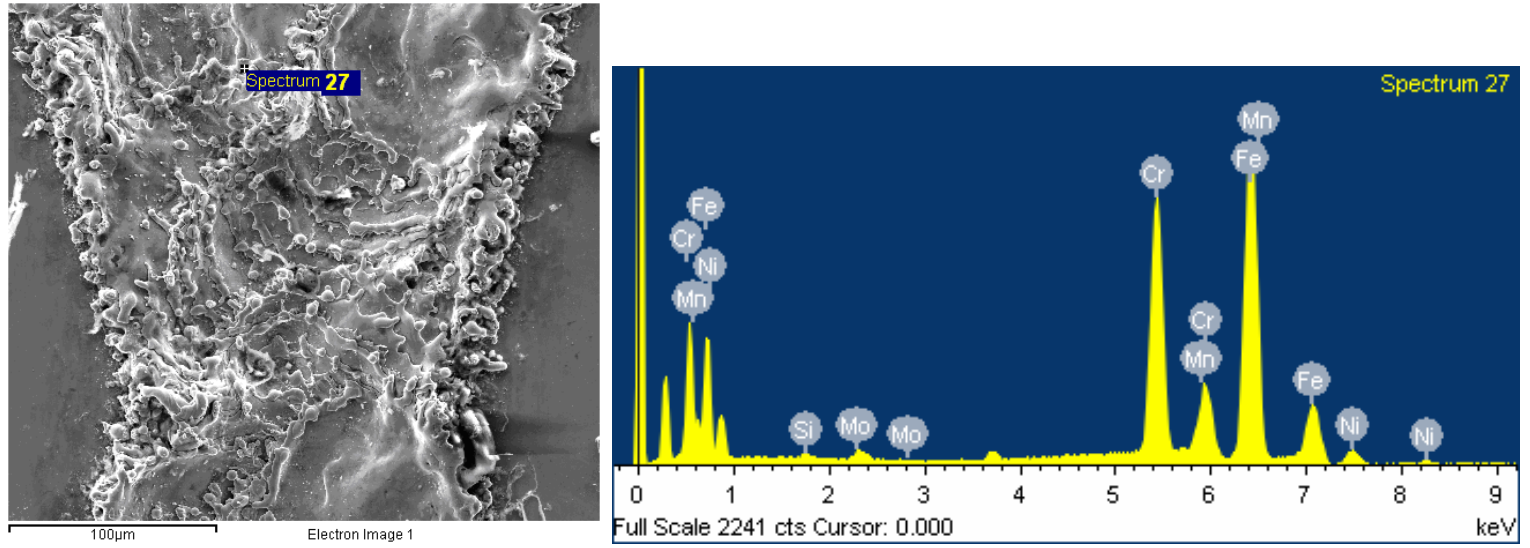

Figura 5.8.4. Espectro de EDS para a região da matriz, cuja área analisada está identificada pelo ponto e corresponde à região fundida duas vezes pelo feixe de raios laser.

Tabela 5.8. Composição química obtida por EDS na região da Figura 5.8.4.

\begin{tabular}{c|cc}
\hline Elemento & \% Massa & \% Atômica \\
\hline & \multicolumn{2}{|}{} \\
\hline Si K & 0,16 & 0,31 \\
\hline Cr K & 27,71 & 29,24 \\
\hline Mn K & 5,14 & 5,13 \\
\hline Fe K & 61,54 & 60,47 \\
\hline Ni K & 4,76 & 4,45 \\
\hline Mo L & 0,69 & 0,39 \\
\hline & \multicolumn{2}{c}{} \\
\hline Total & 100,00 &
\end{tabular}
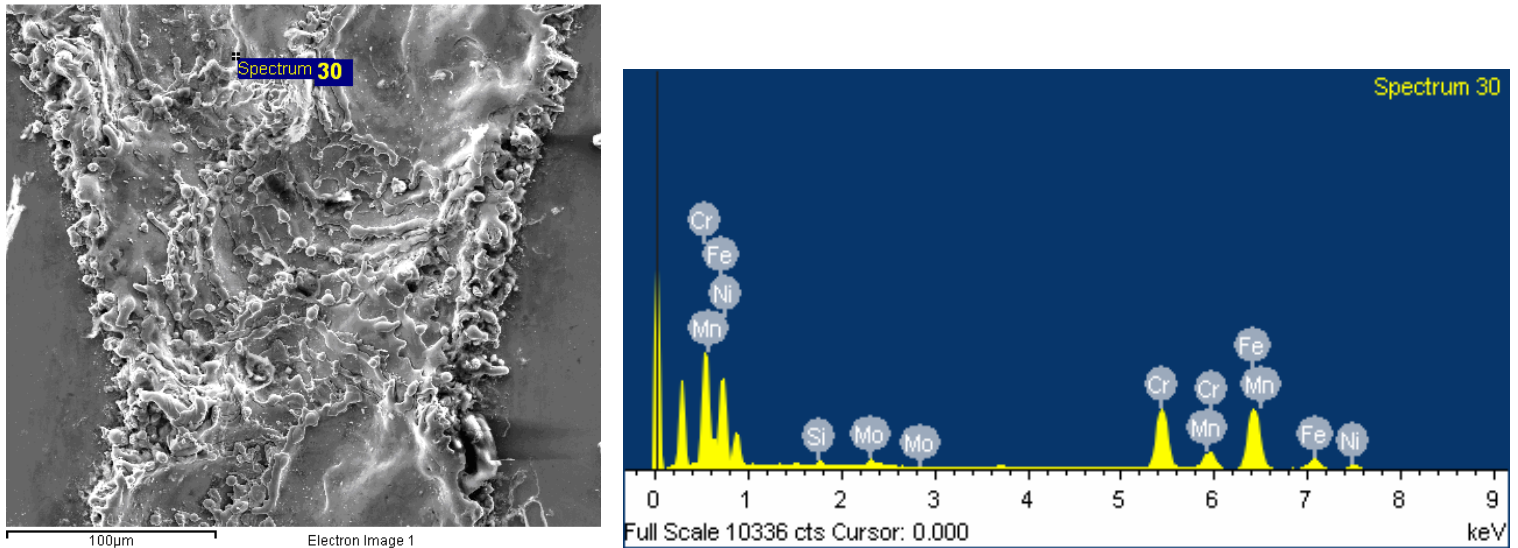

Figura 5.8.5. Espectro de EDS para a região da matriz, cuja área analisada está identificada pelo ponto e corresponde à região fundida duas vezes pelo feixe de raios laser. 
Tabela 5.9. Composição química obtida por EDS na região da Figura 5.8.5.

\begin{tabular}{c|cc}
\hline Elemento & \% Massa & \% Atômica \\
\hline & & \\
\hline Si K & 0,63 & 1,24 \\
\hline Cr K & 30,00 & 31,75 \\
\hline $\mathrm{Mn} \mathrm{K}$ & 6,07 & 6,08 \\
\hline $\mathrm{Fe} \mathrm{K}$ & 53,80 & 53,00 \\
\hline $\mathrm{Ni} \mathrm{K}$ & 6,85 & 6,42 \\
\hline $\mathrm{Mo} \mathrm{L}$ & 2,65 & 1,52 \\
\hline & \multicolumn{2}{c}{} \\
\hline Total & 100,00 & \\
\hline
\end{tabular}

As imagens apresentadas na sequência se referem às microestruturas conhecidas como "etch pit", como explicado anteriormente, não possuem caráter eletroquímico, mas são relacionadas à densidade de discordâncias no aço inoxidável, geradas na zona afetada pelo calor, cuja visualização fora possível unicamente após ataque em solução de água régia. Foram utilizados outros tipos de ataques metalográficos indicados na literatura, como por exemplo, ataque eletrolítico em solução de ácido oxálico $10 \%$ V a 1 minuto e, ataques por imersão em soluções de reagentes tipo Vilela e Marble; e esta microestrutura não pôde ser encontrada.

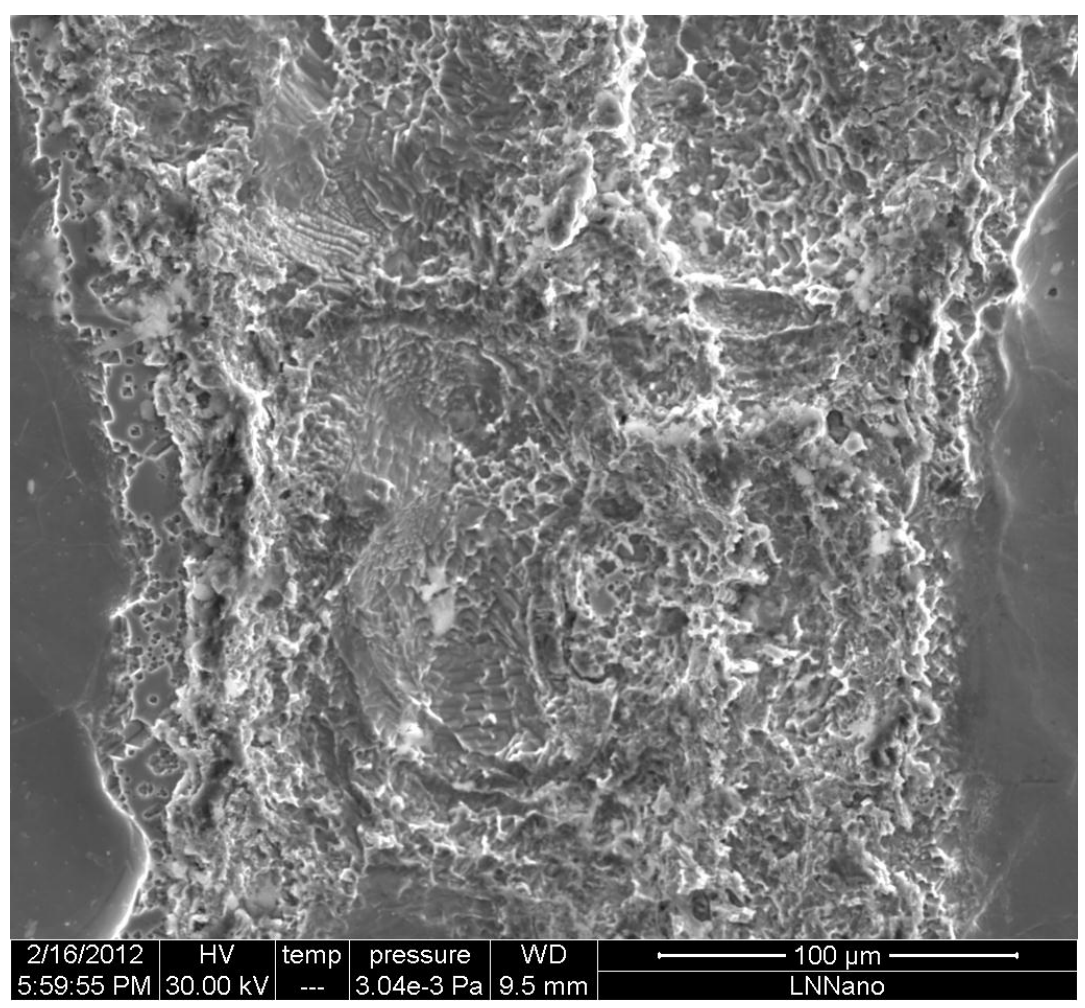

Figura 5.8.6. Etch pit nas regiões adjacentes à fusão gerada pelo laser (zona termicamente afetada) após ataque por imersão em água régia. 
A Figura 5.8.7 (a) e (b) mostra a interface onde foram encontrados os "etch pits", nela podem ser comparados os tamanhos destes "etch pits" em relação aos grãos da matriz. Para a obtenção da imagem em (a) procurou-se dar a mesma proporção para a matriz (substrato) e a área marcada pelo laser.

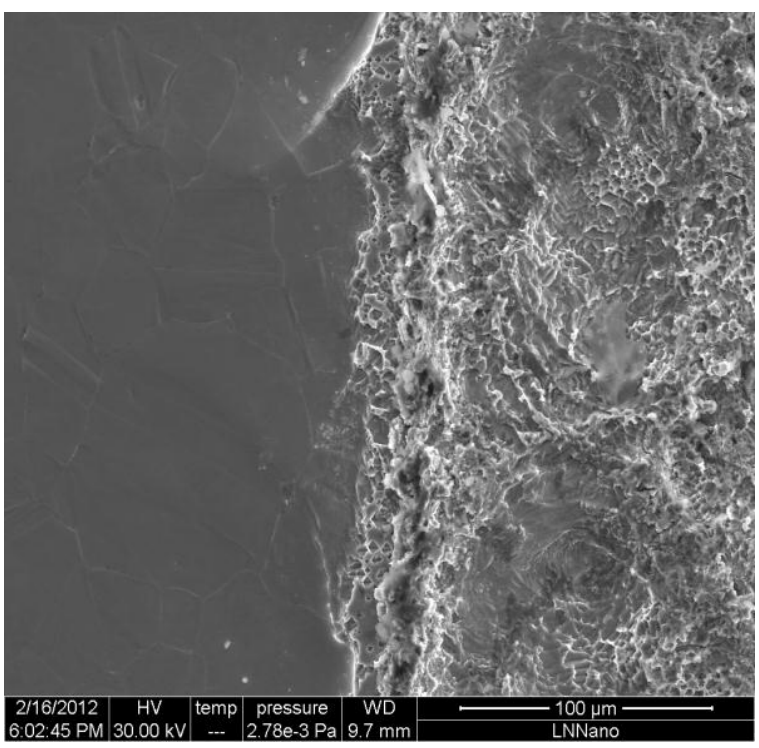

(a)

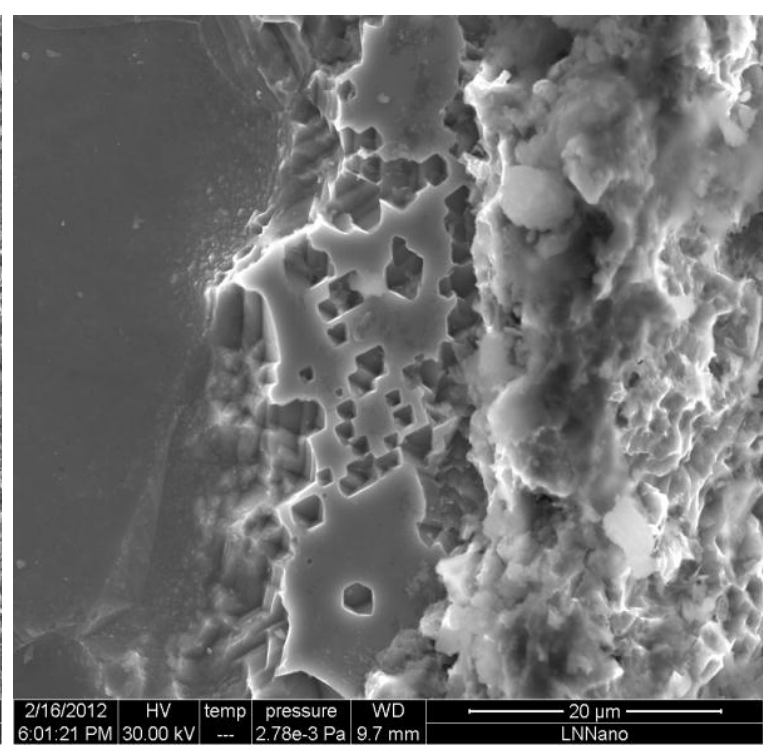

(b)

Figura 5.8.7. (a) Etch pit nas regiões adjacentes à fusão gerada pelo laser (zona termicamente afetada) após ataque por imersão em água régia. (b) Ampliação do etch pit.

A Figura 5.8.7 (b) mostra imagens onde se podem visualizar as interessantes geometrias formadas, que caracterizam estes "etch pits" e são análogas aos sólidos geométricos: cubos, pirâmides e tetraedros.

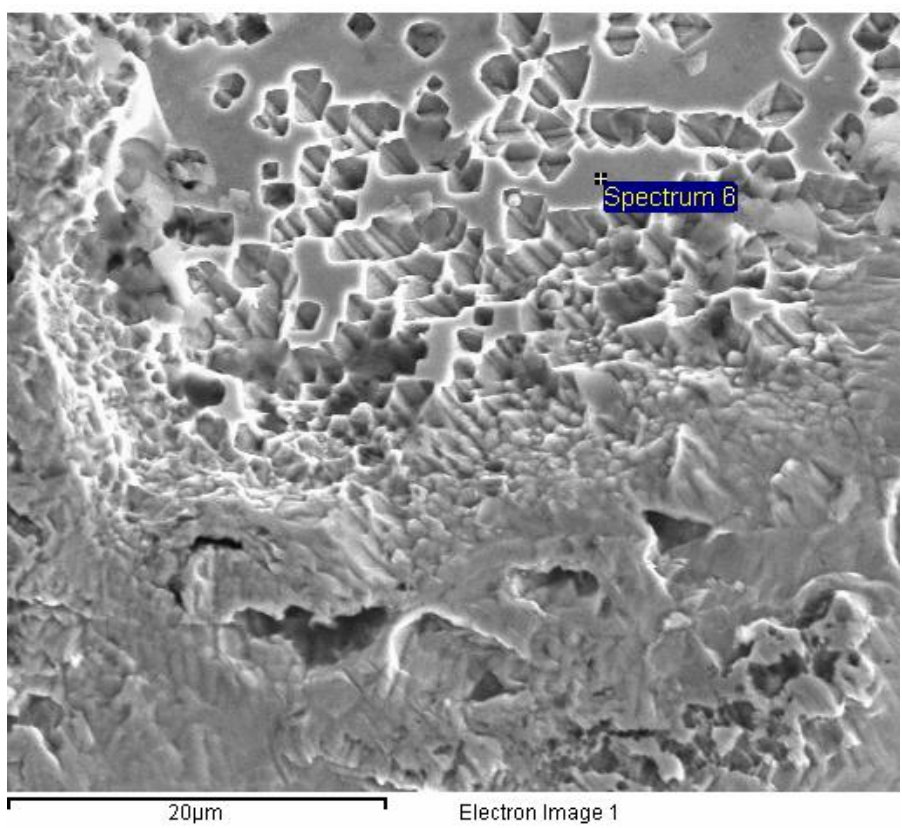

Figura 5.8.8. Etch pit nas regiões adjacentes à fusão gerada pelo laser (zona termicamente afetada) após ataque por imersão em água régia. 


\subsection{Técnica Eletroquímica de Varredura com Eletrodo Vibrante (SVET)}

Com o intuito de se investigar mais o efeito causado pelo laser nas amostras do aço inoxidável austenítico ABNT NBR ISO 5832-1, foram realizados ensaios de varredura com eletrodo vibrante. Com a utilização desta técnica foi possível a determinação das áreas onde se encontravam as maiores densidades de correntes de corrosão, evidenciando perfeitamente as zonas anódicas e catódicas.

Por se tratar de uma técnica altamente localizada, foi possível selecionar regiões que compreendessem unicamente uma gravação (somente um algarismo oito), bem como áreas menores, correspondentes à metade e, à frações da marcação e, regiões um pouco mais ampliadas estabelecendo-se limites através de janelas entre as marcações e a matriz. Os resultados e comentários que seguem estão representados na forma de imagens e mapas em 2D e 3D.

Antes de iniciarem-se os ensaios, houve a necessidade de se medir a condutividade e resistividade da solução e as profundidades e alturas relativas resultantes da técnica de marcação a laser, já que este procedimento funde o material gerando regiões de "vales" e "picos" onde o material é expulso e depositado.

A condutividade e a resistividade da solução salina de fosfato tamponada (PBS) com pH 7,4 estão na Tabela 5.10.

Tabela 5.10. Condutividade e resistividade da solução PBS.

\begin{tabular}{cc}
\hline $\begin{array}{c}\text { Condutividade } \\
\sigma(\mathrm{mS})\end{array}$ & $\begin{array}{c}\text { Resistividade } \\
\rho \text { (ohm.cm) }\end{array}$ \\
\hline 15,35 & 65,14 \\
\hline
\end{tabular}

A Tabela 5.11 apresenta as medidas das alturas e profundidades (médias) geradas pela fusão do laser. Estas medidas foram necessárias para se estabelecer uma distância (z) segura entre o microeletrodo e a amostra. 
Tabela 5.11. Medidas de alturas e profundidades (médias) geradas pela fusão do laser.

\begin{tabular}{cccc}
\hline $\begin{array}{c}\text { Lado direito } \\
(\mu \mathrm{m})\end{array}$ & $\begin{array}{c}\text { Lado esquerdo } \\
(\mu \mathrm{m})\end{array}$ & $\begin{array}{c}\text { Centro do oito } \\
(\text { profundidade })(\mu \mathrm{m})\end{array}$ & $\begin{array}{c}\text { Centro do oito } \\
(\text { do pico ao vale })(\mu \mathrm{m})\end{array}$ \\
\hline $35 \pm 3,53$ & $50 \pm 1,52$ & $100 \pm 4,94$ & $86 \pm 8,08$
\end{tabular}

A Figura 5.9.1 mostra umas das regiões selecionadas para análise por SVET, correspondente à região de centro do oito. As Figuras 5.9.2 e 5.9.3 são mapas em 2D e 3 D da região mostrada na Figuras 5.9.1.

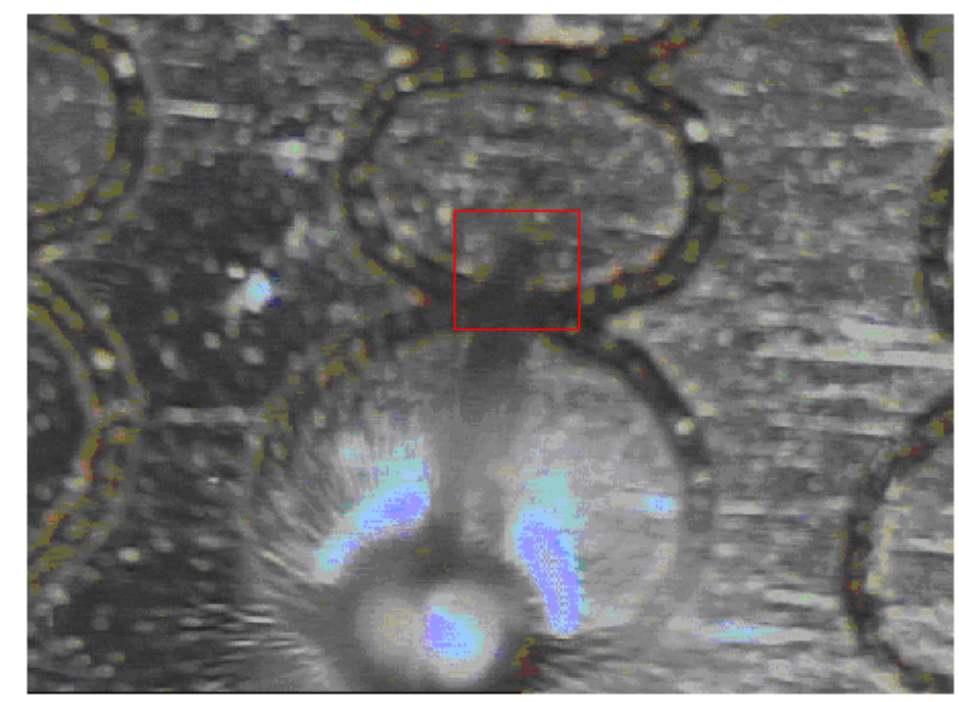

Figura 5.9.1. Região selecionada para análise, com detalhe para o microeletrodo utilizado.
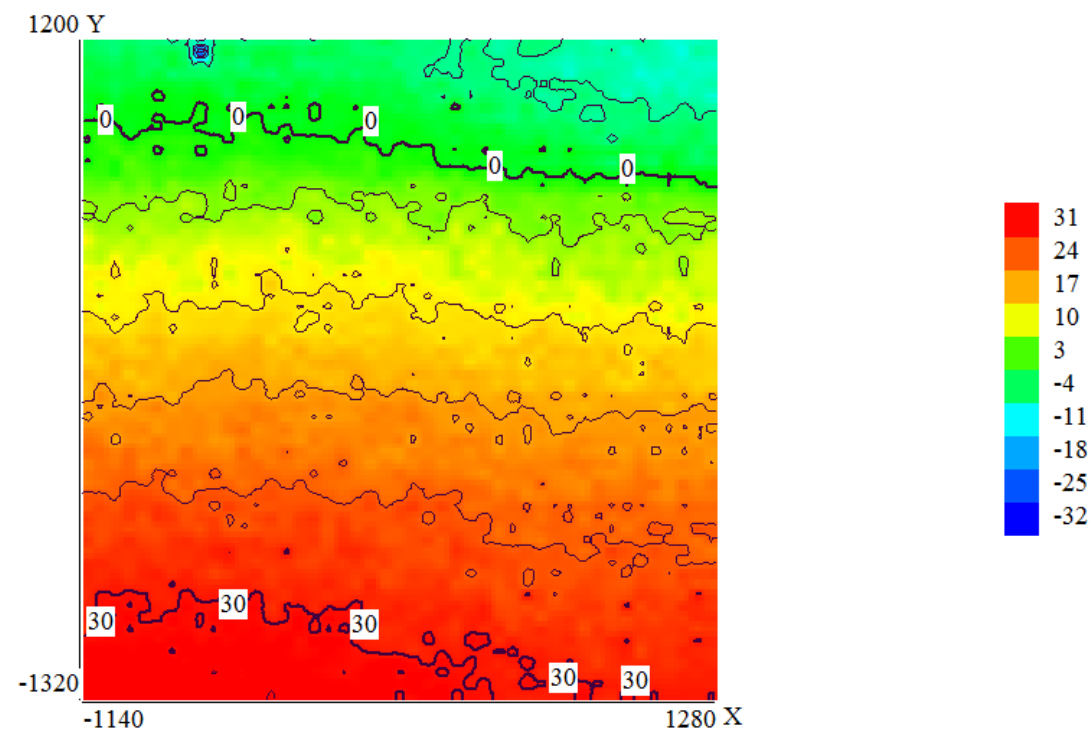

Figura 5.9.2. Mapa em 2D correspondente à região mostrada na Figura 5.9.1 representando as áreas com maior densidade de correntes anódicas (vermelho) e catódicas (azul). 


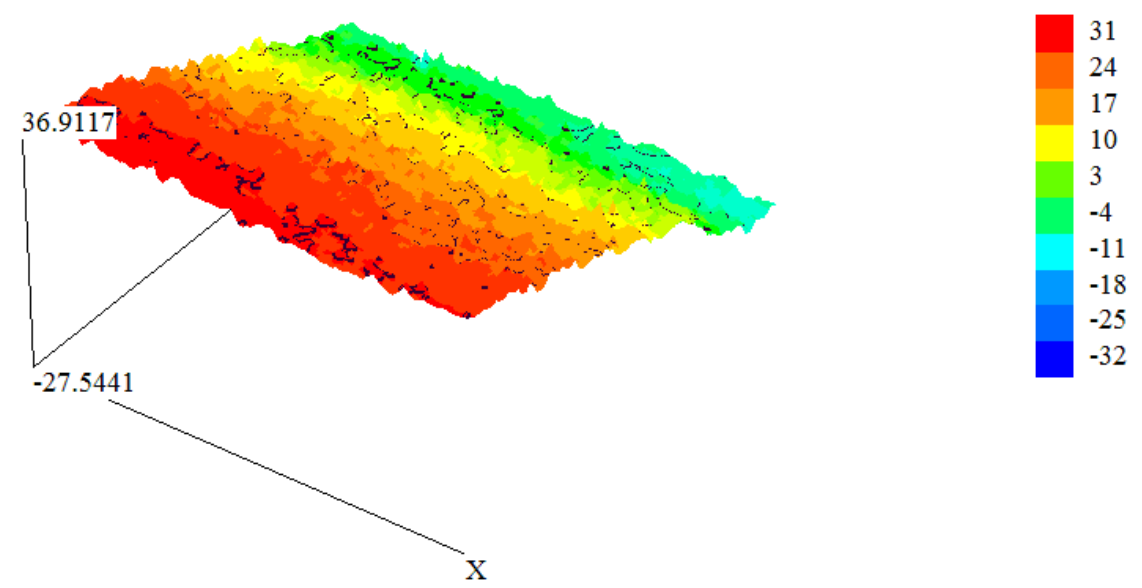

Figura 5.9.3. Mapa em 3D correspondente à região mostrada na Figura 5.9.1.

Estes resultados evidenciaram que as maiores correntes (anódicas), representadas pela cor vermelha, são encontradas na região central do oito, ou seja, onde o feixe de laser incidiu duplamente e, as menores correntes (catódicas), representadas pela cor azul, na área onde não houve a incidência do feixe de raios laser; como pode ser observado nas Figuras 5.9.4 e 5.9.5.

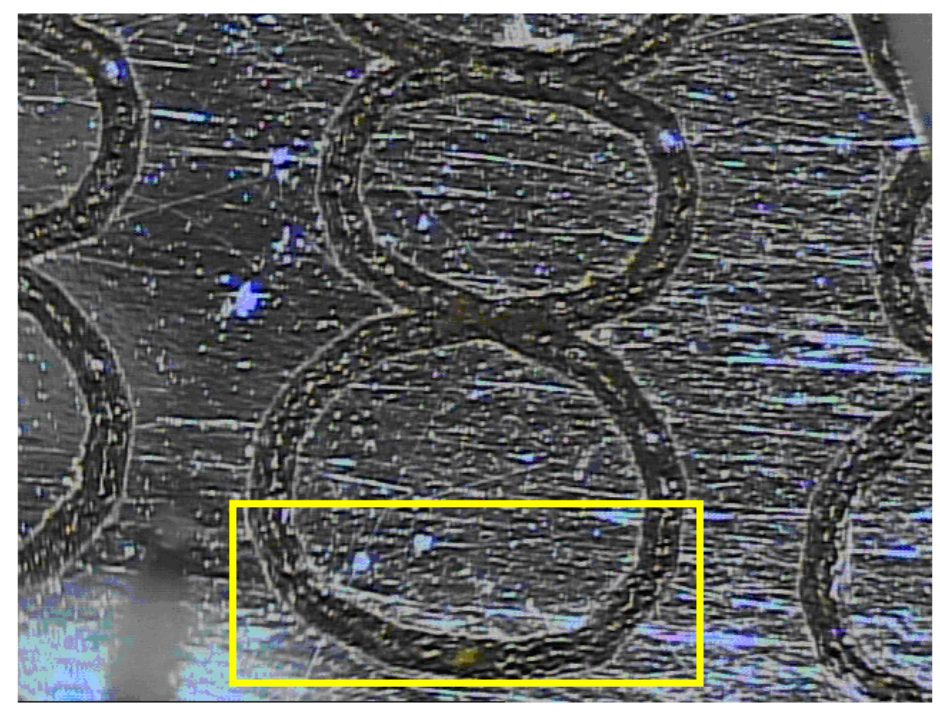

Figura 5.9.4. Região selecionada para análise, com detalhe para o microeletrodo utilizado. 


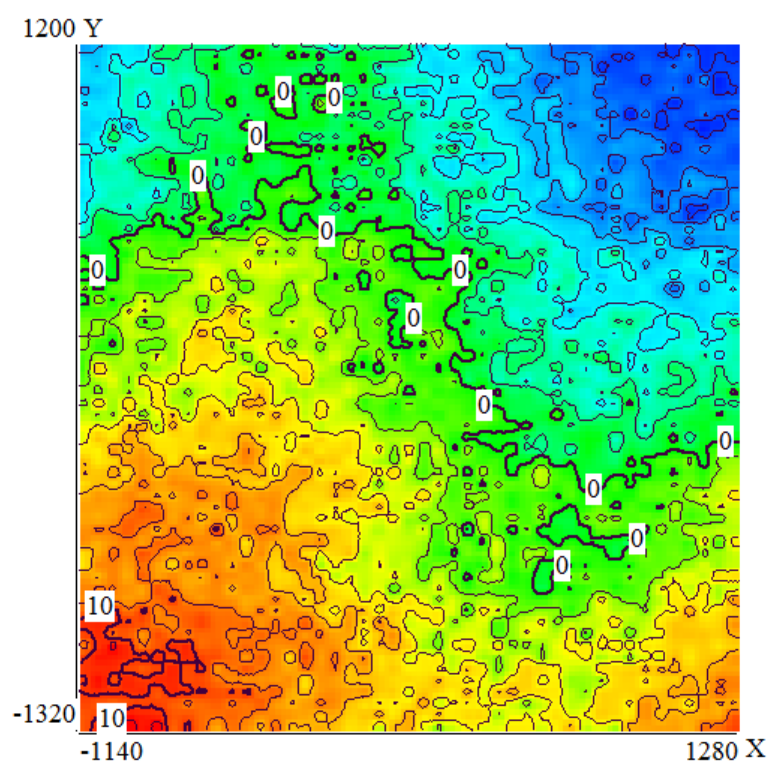

Figura 5.9.5. Mapa em 2D correspondente à região mostrada na Figura 5.9.4.

$\mathrm{Na}$ Figura 5.9.4 foi selecionada uma região onde o feixe de raios laser incidiu uma única vez. Nota-se que também são encontradas densidades de correntes anódicas relacionadas às áreas com marcação a laser, embora de menor magnitude do que as encontradas onde foram duplamente afetadas pelo laser, conforme a Figura 5.9.5 mostra. A Figura 5.9.6 é um mapa em 3D das densidades de correntes obtidas na área selecionada.

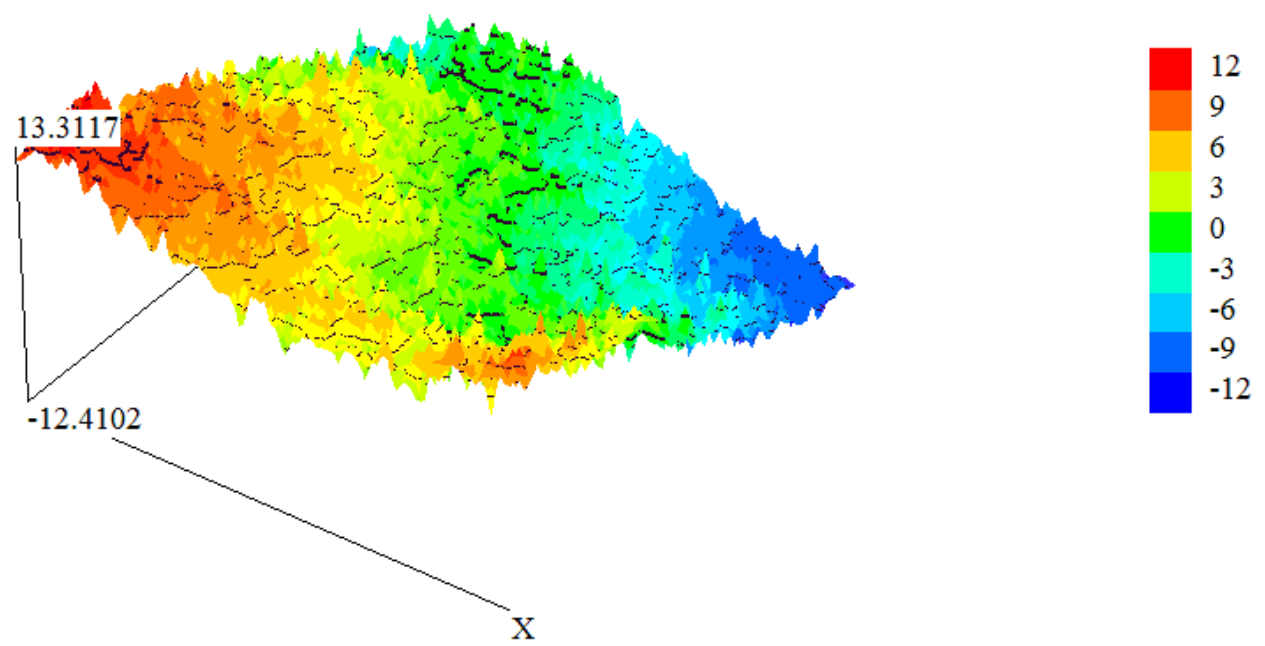

Figura 5.9.6. Mapa em 3D correspondente à região mostrada na Figura 5.9.4.

Com o propósito de se determinar o comportamento das correntes de corrosão na região fundida pelo laser duas vezes e sua vizinhança (zona termicamente afetada), foram selecionadas regiões diversas sempre passando 
pelo centro do algarismo oito, como estão apresentadas nas Figuras 5.9.7 a 5.9.17.

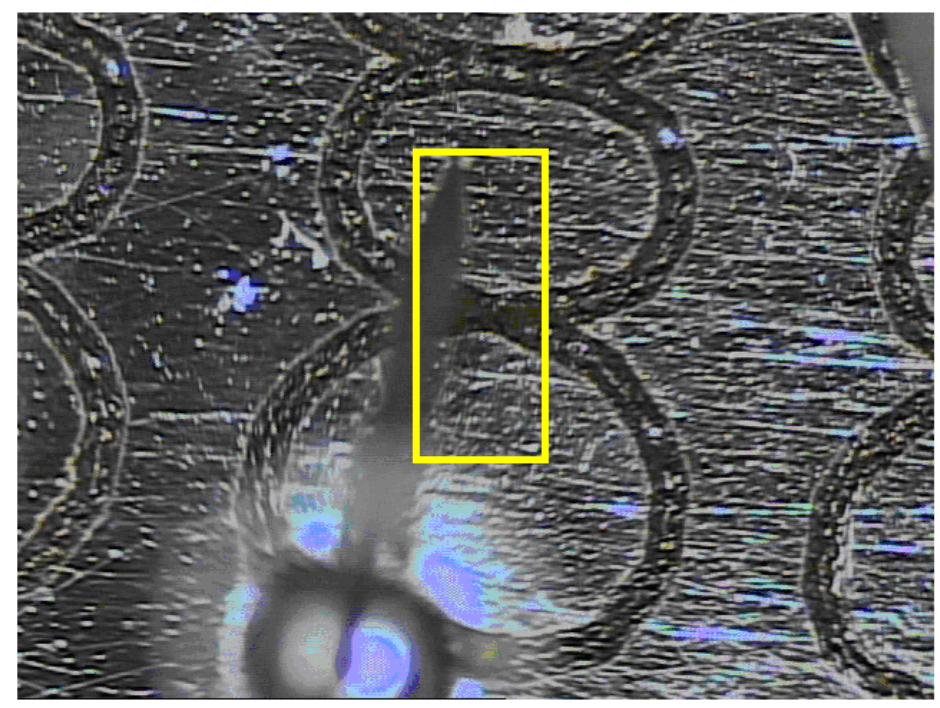

Figura 5.9.7. Região selecionada para análise, com detalhe para o microeletrodo utilizado, passando pelo centro do oito.

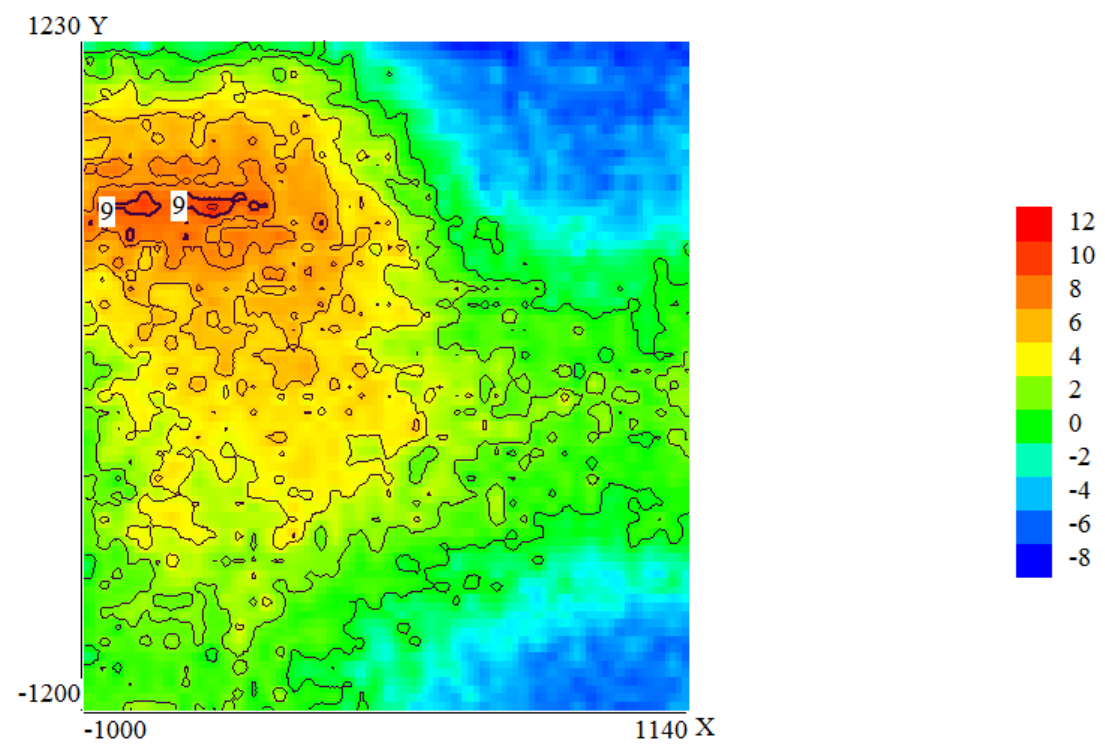

Figura 5.9.8. Mapa em 2D correspondente à região mostrada na Figura 5.9.7. 

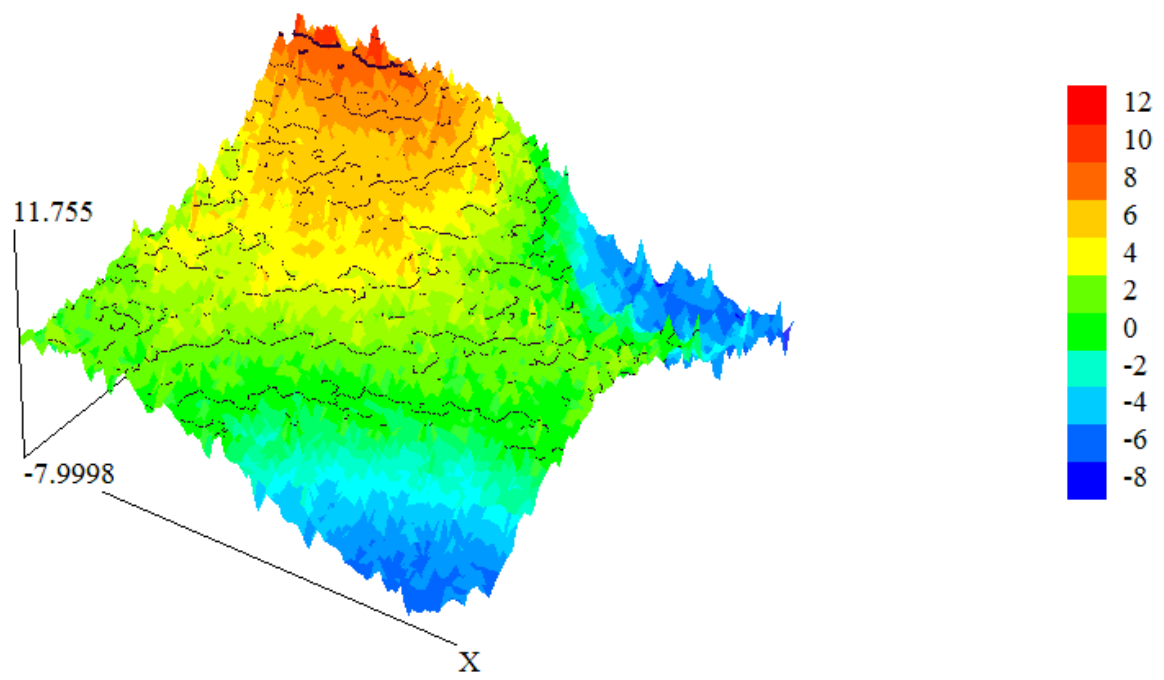

Figura 5.9.9. Mapa em 3D correspondente à região mostrada na Figura 5.9.7.

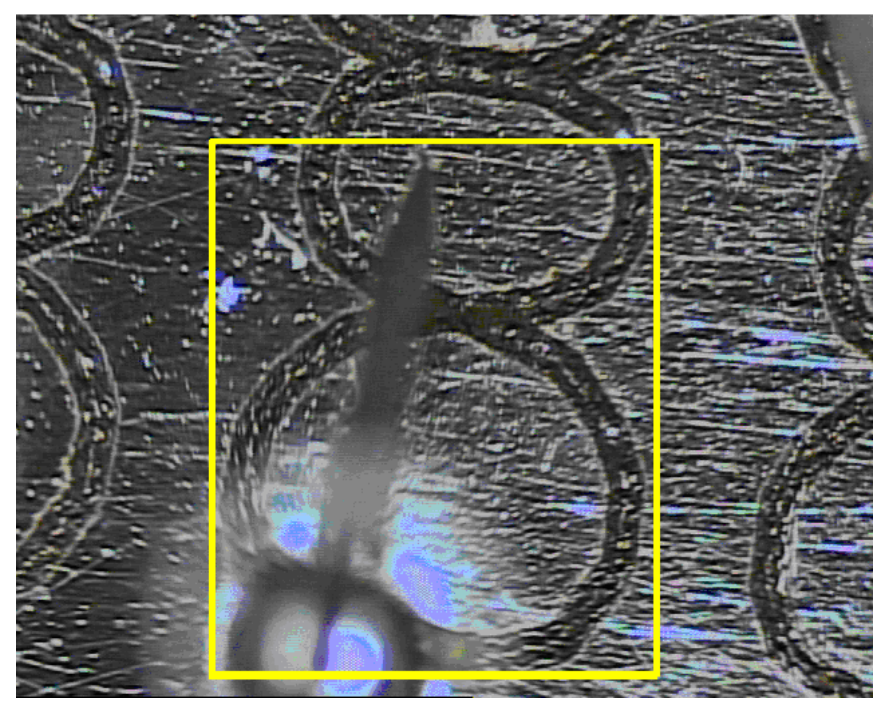

Figura 5.9.10. Região selecionada para análise, com detalhe para o microeletrodo utilizado, anel inferior do oito.
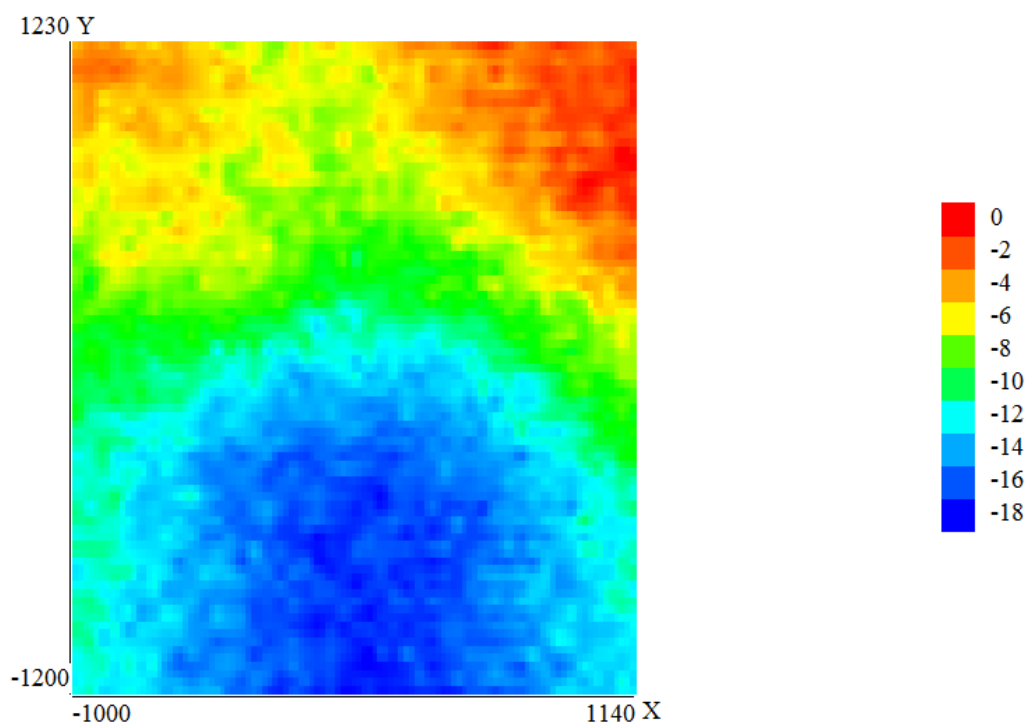

Figura 5.9.11. Mapa em 2D correspondente à região mostrada na Figura 5.9.10. 

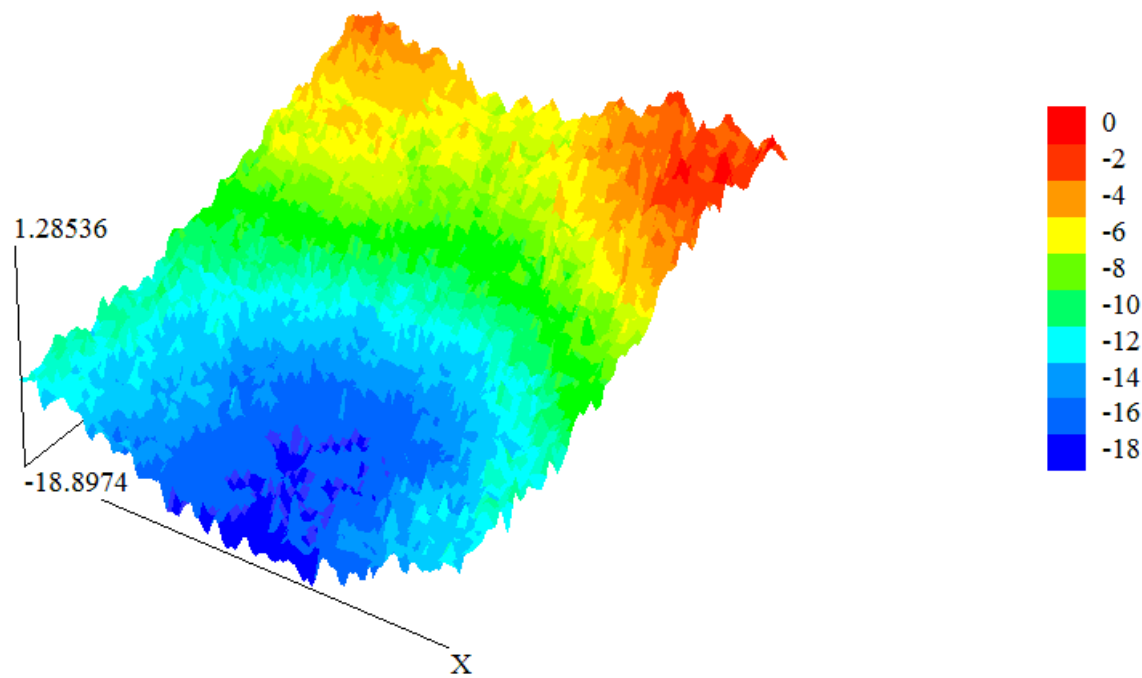

Figura 5.9.12. Mapa em 3D correspondente à região mostrada na Figura 5.9.10.

Repetindo-se a medida na mesma área selecionada apresentada na Figura 5.9.10, após tempos de imersão mais longos, encontram-se regiões menos anódicas e mais catódicas, o que sugere um crescimento, mesmo que mínimo, do filme passivo nestas condições, conforme está apresentado nas Figuras 5.9.13 e 5.9.14. A Figura 5.9.14 (a) corresponde a um período de $17 \mathrm{~h}$ de imersão e, (b) após $24 \mathrm{~h}$ de imersão.

Após estes tempos de imersão o crescimento do filme passivo dificulta a visualização da distribuição de áreas anódicas e catódicas nas amostras. Estas se tornam mais claramente reveladas sob condições mais agressivas, como por exemplo, polarizando-se as amostras.
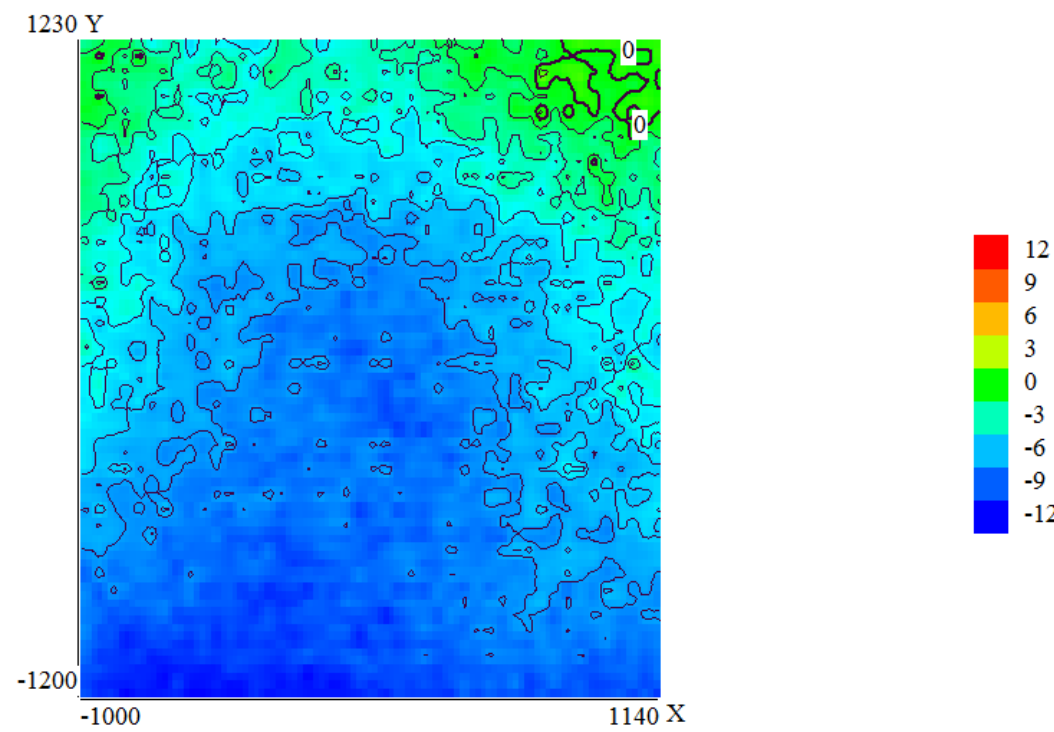

Figura 5.9.13. Mapa em 2D correspondente à região mostrada na Figura 5.9.10, após $24 \mathrm{~h}$ de imersão. 


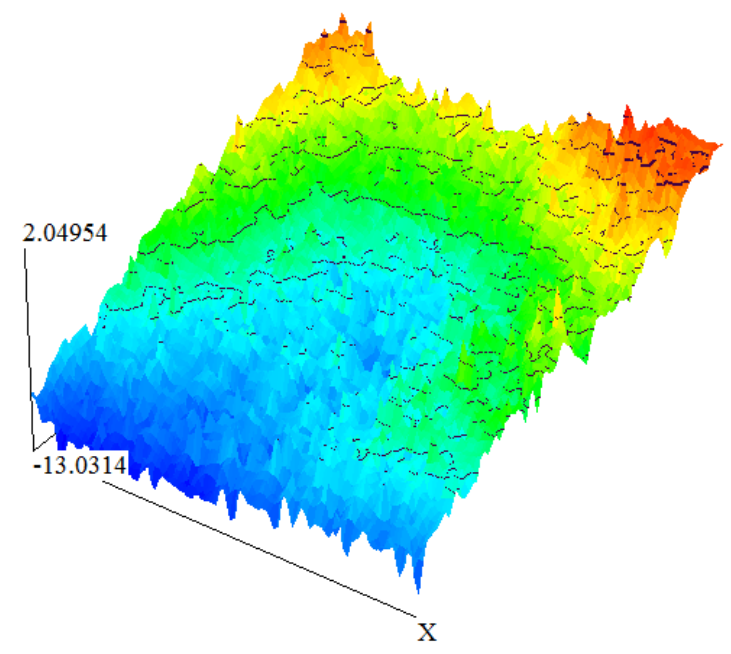

(a)
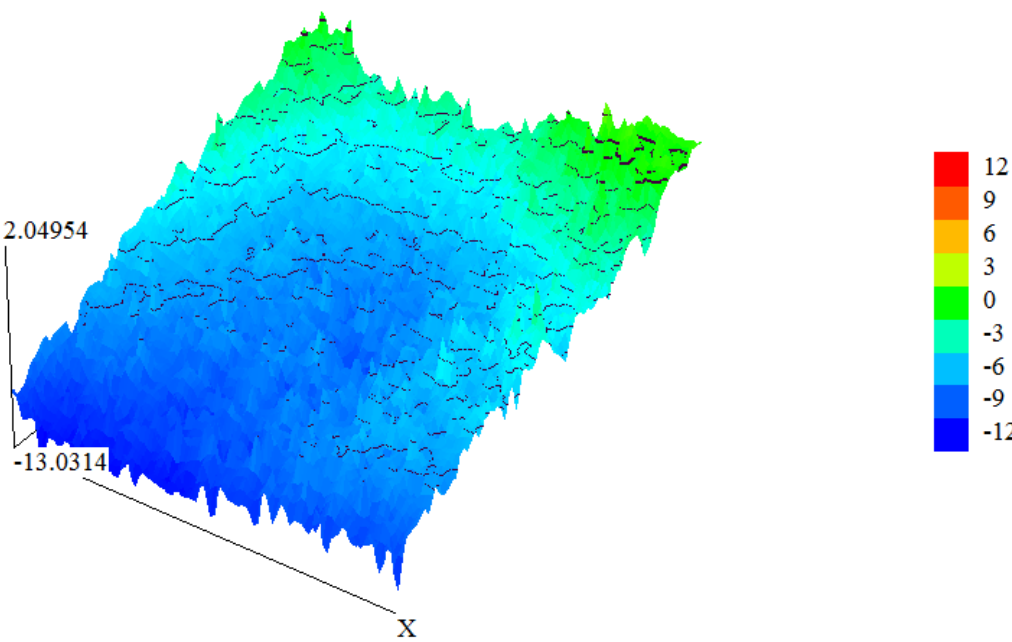

(b)

Figura 5.9.14. Mapa em 3D correspondente à região mostrada na Figura 5.9.10. (a) Após 17h de imersão e, (b) após 24h de imersão.

Estas amostras foram então polarizadas a $0,6 \mathrm{~V}$ e, pode ser observada a distribuição das áreas anódicas na zona afetada pelo feixe de laser, o que sugere uma correlação entre as características microestruturais e a corrosão localizada, como pode ser observado na Figura 5.9.15. Foram realizadas medidas na seção transversal com amostras embutidas em resina epóxi, lixadas e polidas, Figura 5.9.16. Nelas também se observaram regiões mais anódicas próximas às marcações e mais catódicas longe das mesmas, o que indicou que a densidade de corrente anódica varia, decaindo ao longo da zona termicamente afetada, a partir da marcação em direção ao substrato. 


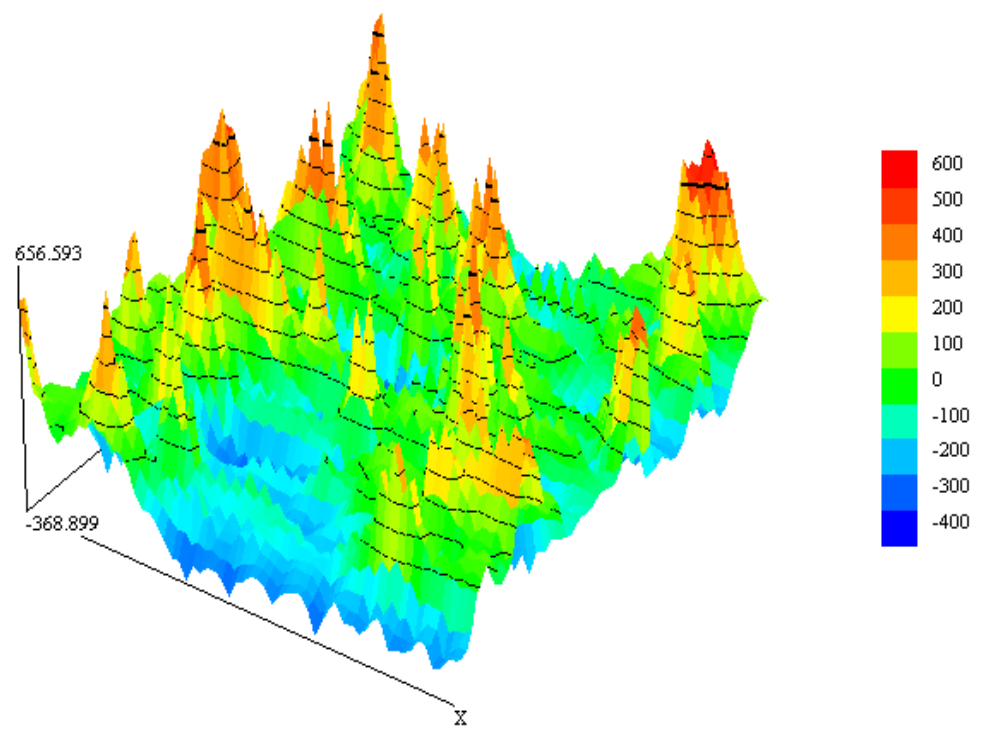

Figura 5.9.15. Mapa em 3D correspondente à região mostrada na Figura 5.9.10, amostra polarizada após $17 \mathrm{~h}$ de imersão.

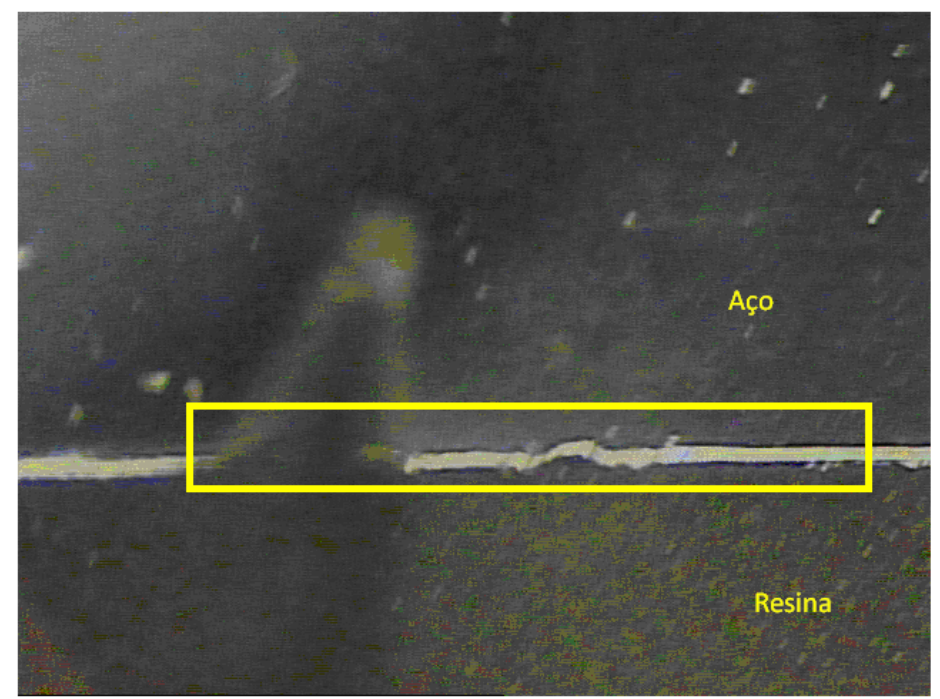

Figura 5.9.16. Região selecionada para análise em seção transversal, com detalhe para o microeletrodo utilizado. 


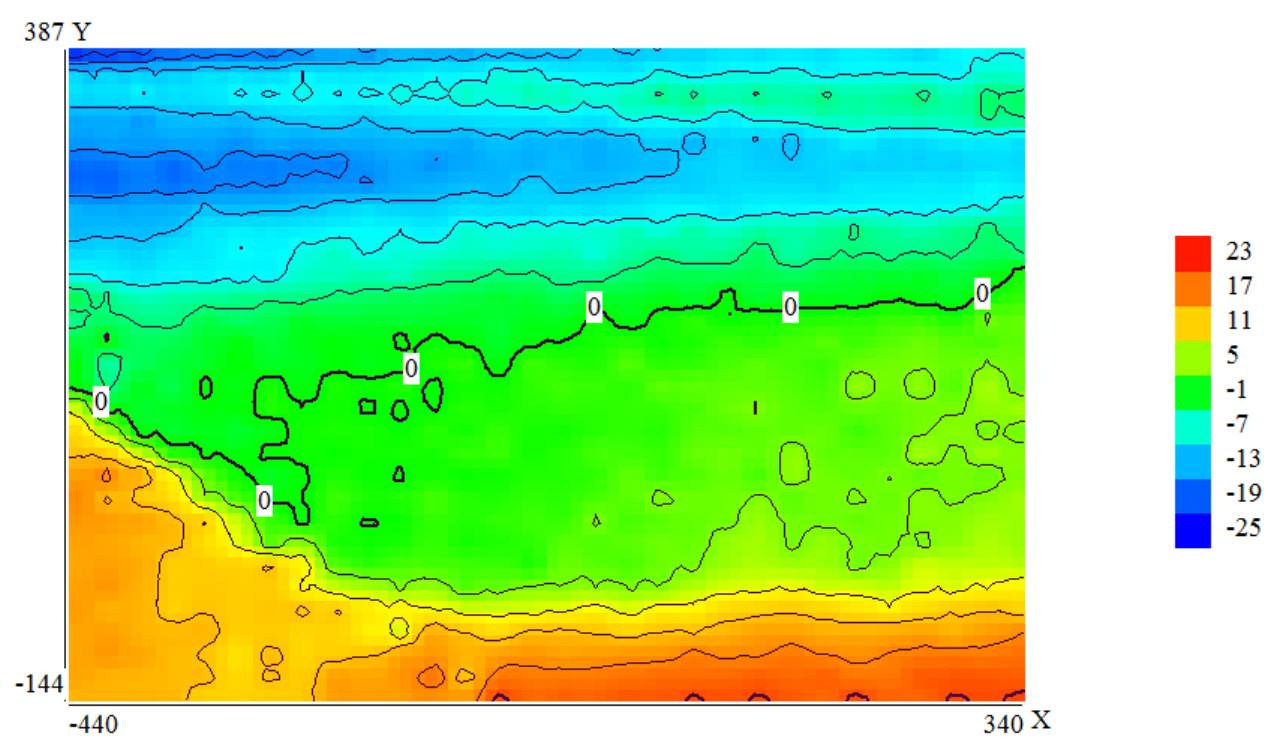

Figura 5.9.17. Mapa em 2D correspondente à região mostrada na Figura 5.9.16.

Os mapas das Figuras 5.9.17 e 5.9.18 mostram em vermelho a região caracterizada por maior densidade de correntes anódicas, onde houve a gravação a laser e, um degradê de cores até o azul, onde se tem a maior densidade de correntes catódicas.

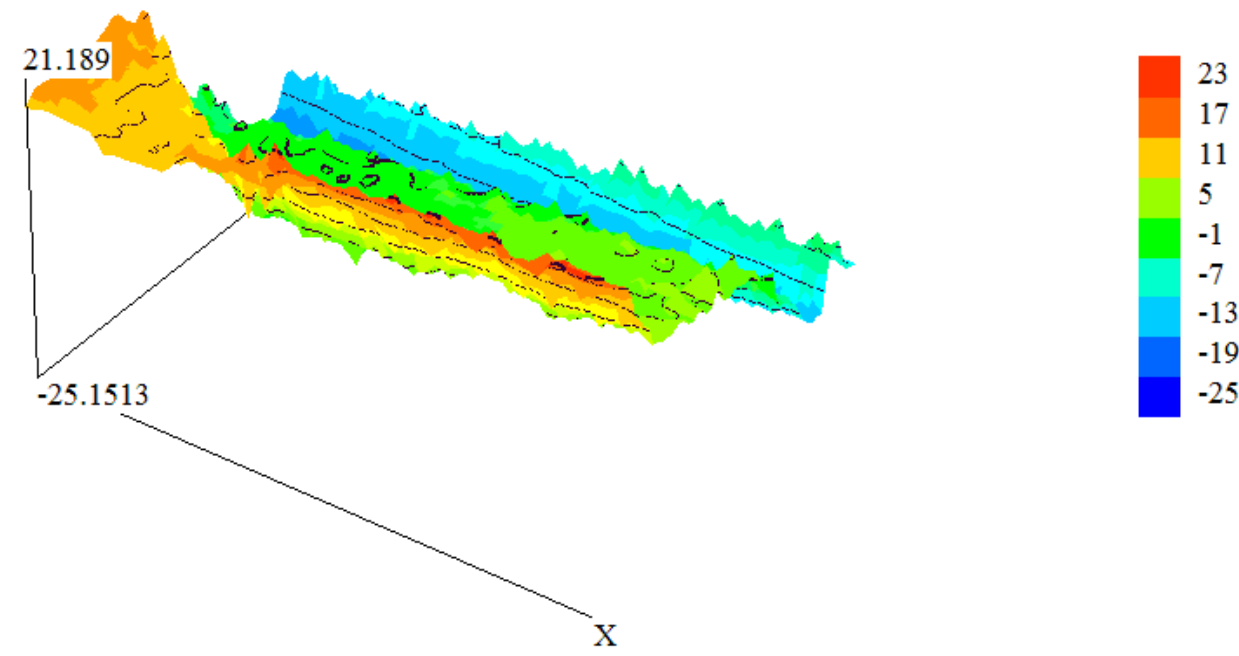

Figura 5.9.18. Mapa em 3D correspondente à região mostrada na Figura 5.9.16.

É importante salientar que a utilização da técnica de SVET permitiu evidenciar que este aço também é susceptível à corrosão por fresta. Em alguns ensaios realizados com janela, ou seja, restringindo uma área e, isolando-a com fita adesiva tipo Durex, após 17h de imersão na referida solução; o efeito da fresta foi preponderante sobre o pite, conforme está apresentado nas figuras seguintes. 


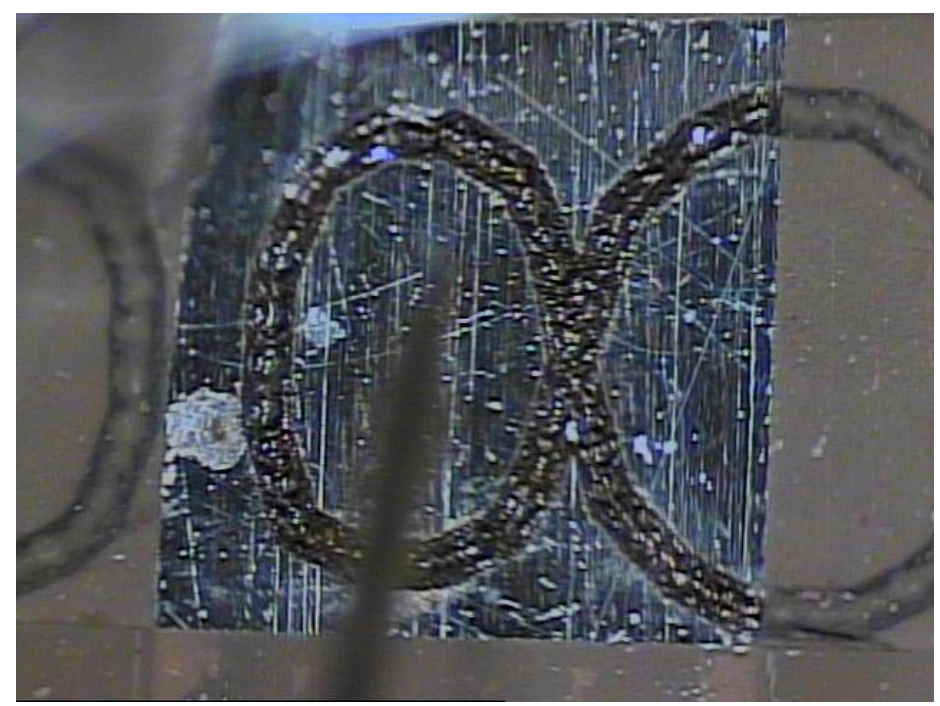

Figura 5.9.19. Região com janela isolada com fita adesiva, com detalhe para o microeletrodo utilizado.

As Figuras 5.9.19, 20 e 21 apresentam, respectivamente, a região selecionada para o ensaio e os mapas gerados, após $17 \mathrm{~h}$ de imersão. No canto inferior direito a fita adesiva está colocada em cima da gravação, o efeito da fresta potencializou esta região de caráter anódico, enquanto que no canto superior esquerdo, a fita não sobrepõe a gravação e, evidencia esta área como sendo anódica também.
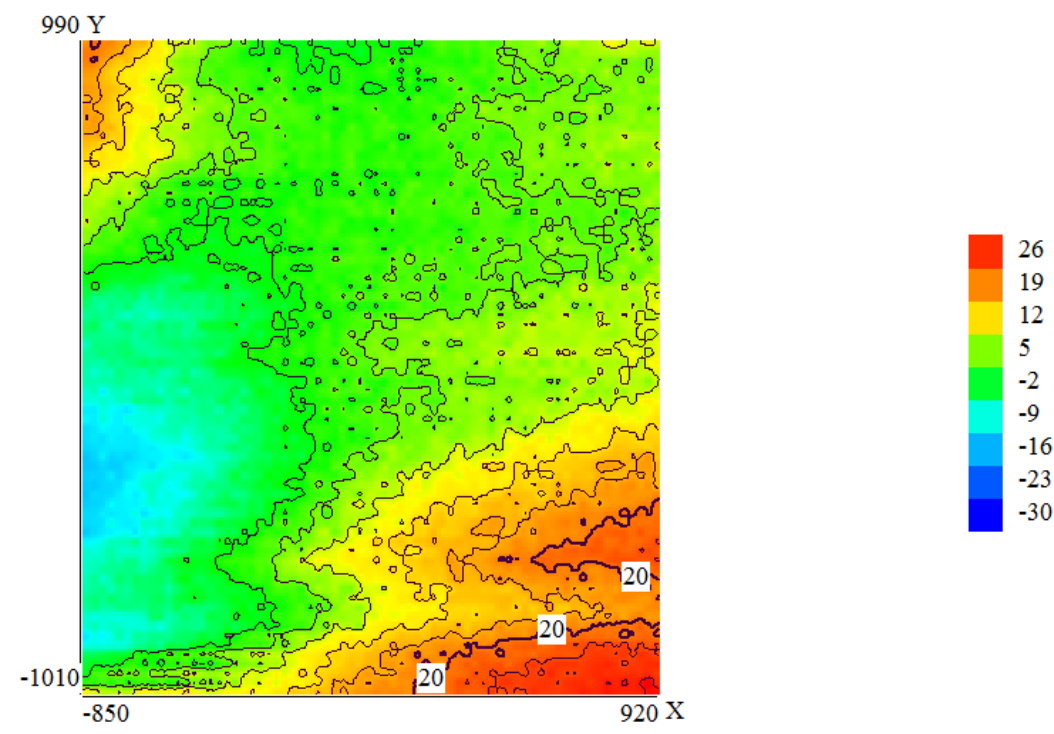

Figura 5.9.20. Mapa em 2D correspondente à região mostrada na Figura 5.9.19, após 17h de imersão. 


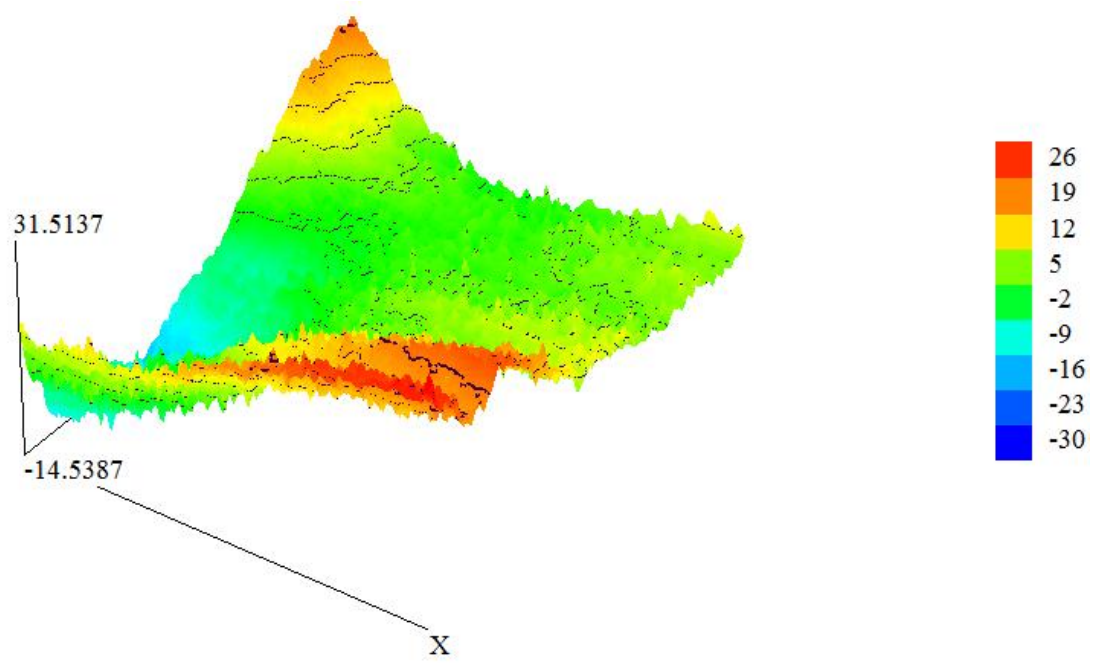

Figura 5.9.21. Mapa em 3D correspondente à região mostrada na Figura 5.9.19.

A condição de fresta gerada na Figura 5.9.19 foi obtida pelo descolamento de partes da fita adesiva devido ao tempo de imersão no eletrólito utilizado; o que proporcionou micro regiões de aeração diferencial. Este fato pode ser correlacionado com o ocorrido na célula plana e apresentado anteriormente na Figura 5.7.8, onde de forma não intencional, foi obtida corrosão em fresta devido ao arranjo experimental utilizado no sistema.

A Figura 5.9.22 é uma micrografia gerada por microscópio óptico da seção transversal analisada, atacada pelo reagente metalográfico Marble, que mostra a zona termicamente afetada pelo processo de marcação a laser.

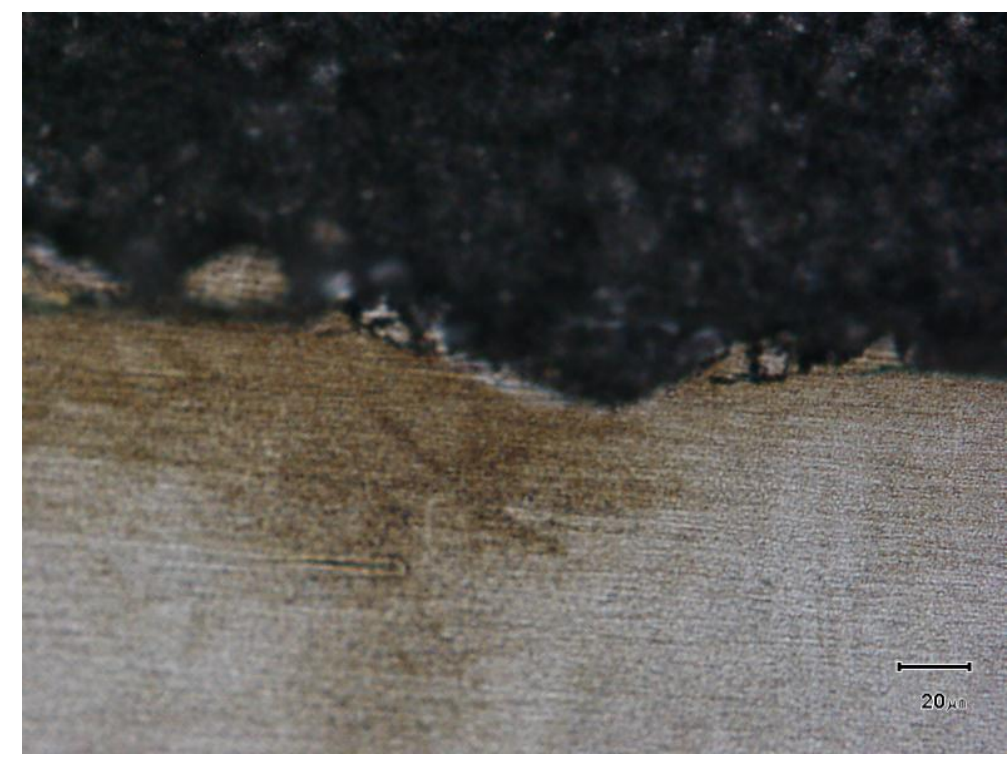

Figura 5.9.22. Microscopia óptica da zona termicamente afetada na seção transversal da amostra marcada pelo laser. 
Foram realizadas análises de EDS na seção transversal, a fim de investigar possível alteração na composição química do aço submetido à técnica de marcação via raios laser, o que não foi verificado. A Figura 5.9.23 mostra a imagem da seção transversal analisada.

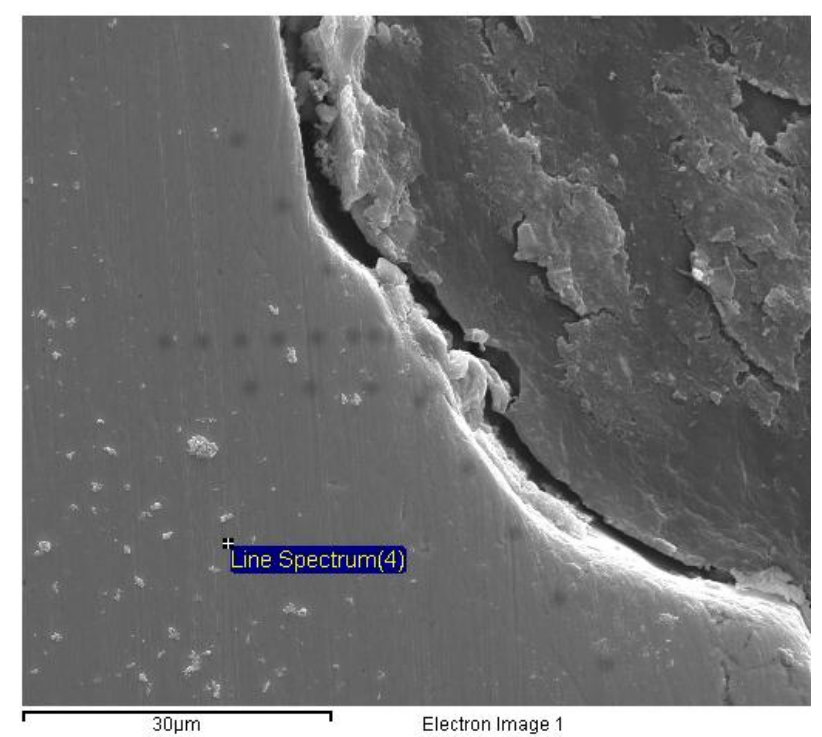

Figura 5.9.23. Seção transversal da amostra marcada pelo laser.

As análises semiquantitativas de EDS realizadas na seção transversal apresentaram a seguinte composição: $58,46 \% \mathrm{Fe}, 18,53 \% \mathrm{Cr}, 1,79 \% \mathrm{Si}, 3,21 \%$ $\mathrm{Mn}, 14,37 \%$ Ni e 3,73\% Mo, típica do aço, com leve enriquecimento em Mo e Ni.

\subsection{Técnicas de Caracterização Complementares}

Os efeitos da técnica de marcação de biomateriais via raios laser sobre o aço inoxidável austenítico estudado foram investigados por análises complementares para a caracterização da região afetada pelo calor, uma vez que as análises utilizadas anteriormente não haviam proporcionado justificativa para a diminuição da susceptibilidade à corrosão por pite das amostras marcadas a laser, nem o fato de terem sido encontradas regiões enriquecidas em cromo com relação à matriz.

Em um primeiro momento considerou-se a possível formação de fase ferrita delta, o que foi descartado após análises via ferritoscópio. Foi então 
utilizada a Microscopia Eletrônica de Transmissão (MET). Os resultados provenientes desta técnica estão apresentados a seguir.

A Figura 5.10.1 mostra uma seqüência de imagens obtidas por microscopia eletrônica de transmissão onde se observa a microestrutura da região do aço inoxidável afetada pela técnica de gravação a laser. Nela observa-se elevada densidade de discordâncias e a presença de precipitados.

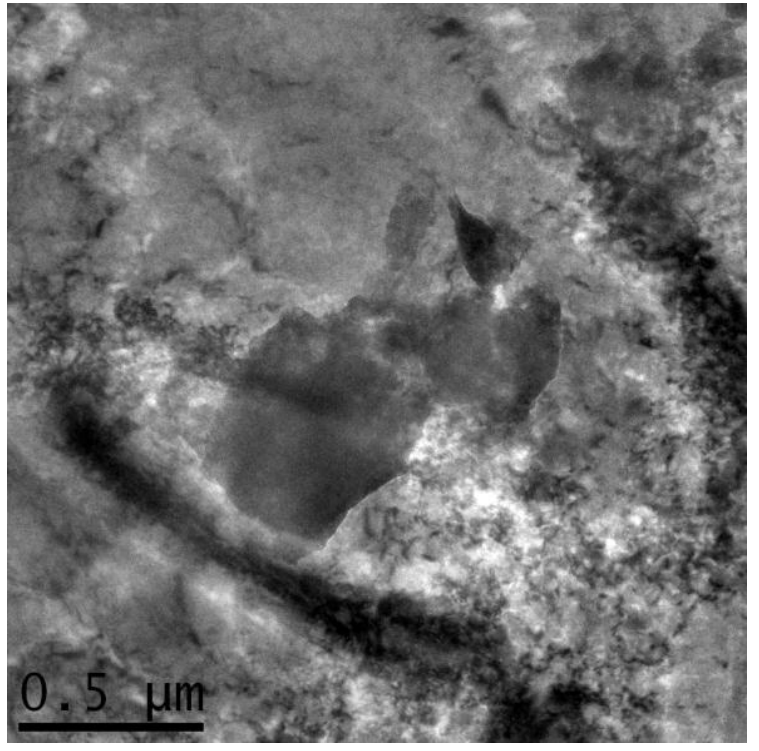

(a)

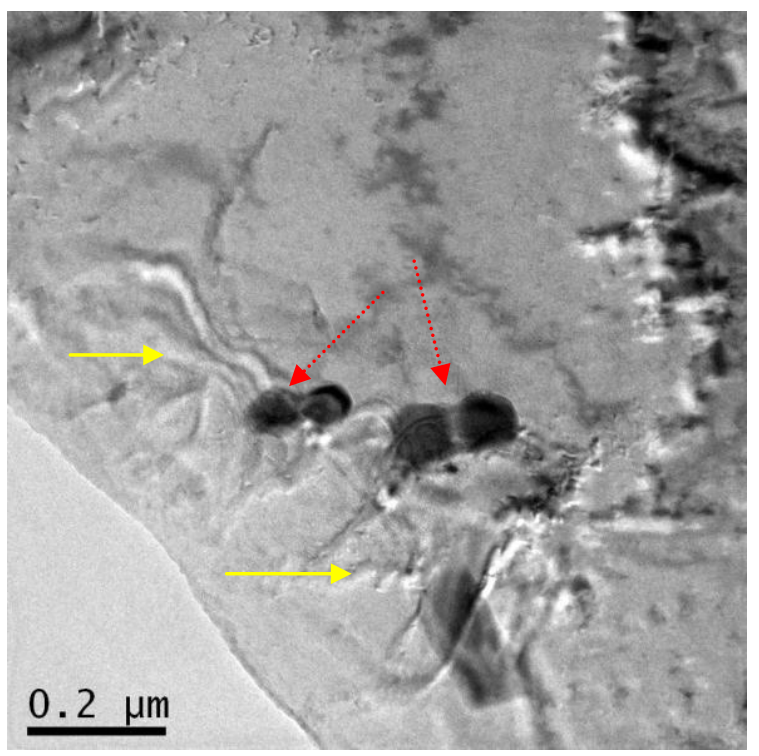

(c)

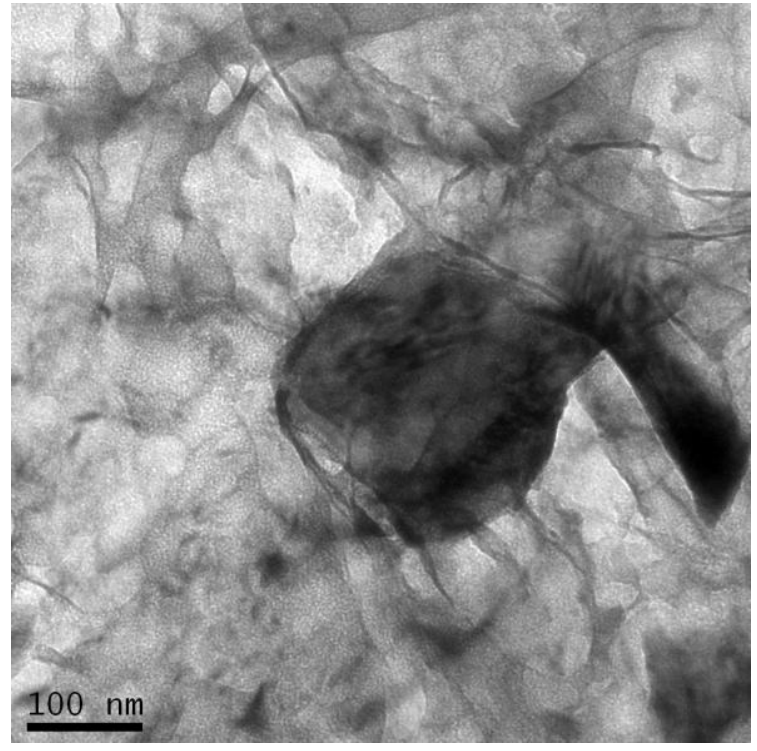

(b)

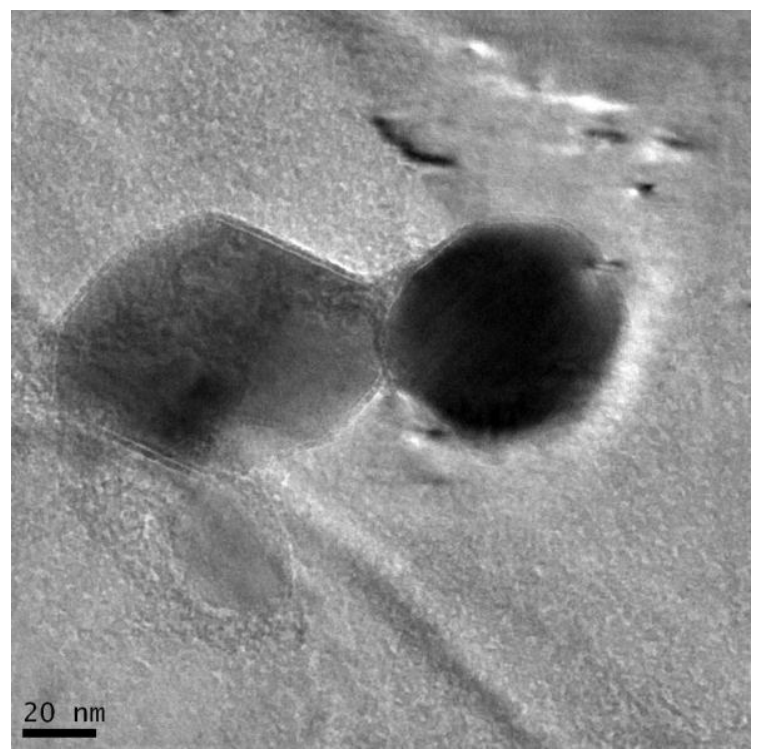

(d)

Figura 5.10.1. Microscopia Eletrônica de Transmissão (MET) do aço inoxidável austenítico ABNT NBR ISO 5832-1, gravado a laser, evidenciando grande densidade de discordâncias (setas amarelas) e inclusões (setas vermelhas). 
As análises semiquantitativas realizadas nas inclusões observadas na Figura 5.10.1 (b), (c) e (d), constataram tratarem-se de precipitados de óxidos de silício e de alumínio. Estes precipitados de óxido de alumínio apresentaram-se com formatos mais arredondados, já os de óxido de silício, com formatos de paralelepípedos, conforme a Figura 5.10.2 mostra.

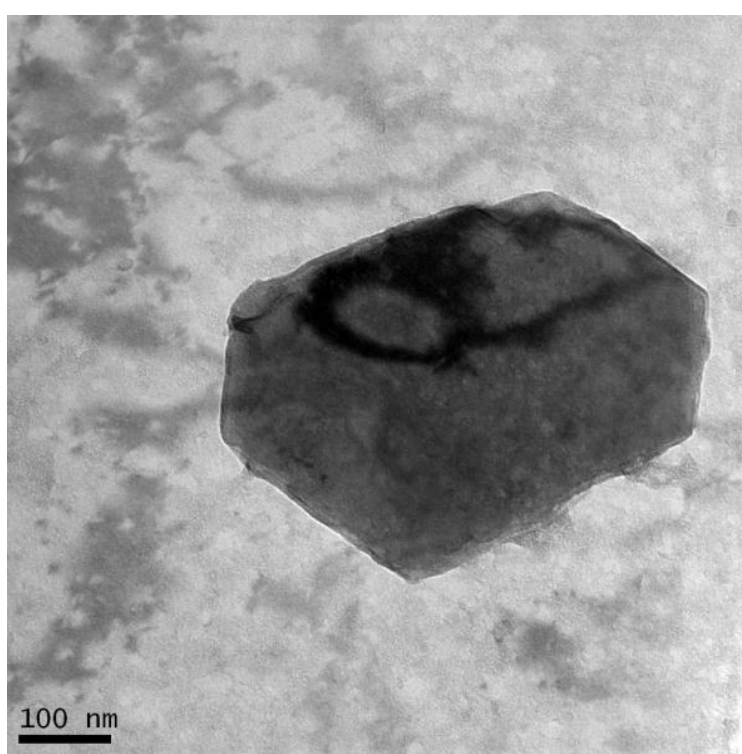

(a)

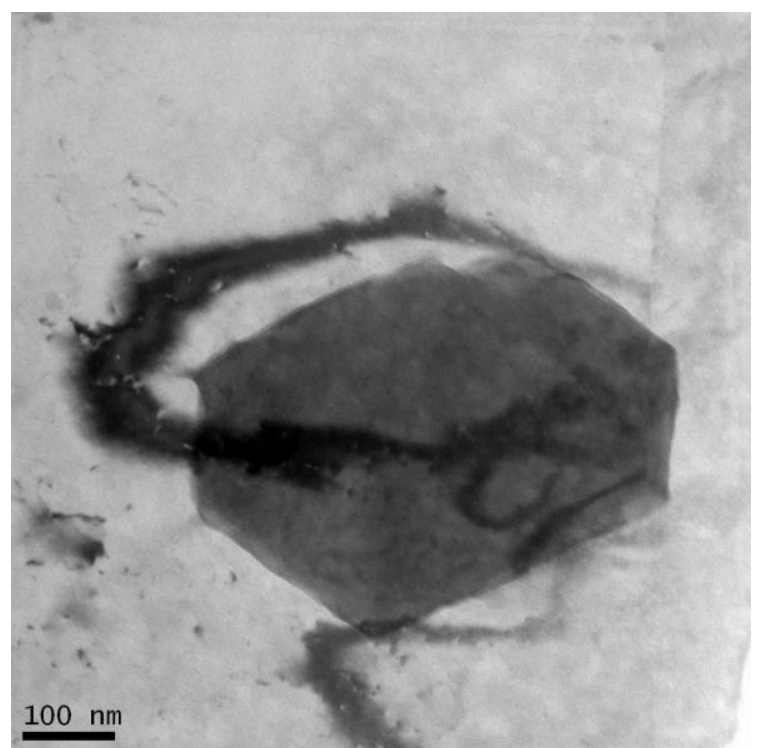

(b)

Figura 5.10.2. Microscopia Eletrônica de Transmissão (MET) do aço inoxidável austenítico ABNT NBR ISO 5832-1, gravado a laser, evidenciando um precipitado de óxido de silício.

A elevada densidade de discordância produzida pelo feixe de raios laser nas amostras do referido aço inoxidável pode ser conferida através das imagens obtidas via Microscopia Eletrônica de Transmissão (MET) e mostradas nas Figuras 5.10 .3 e 5.10.4. Também podem ser observadas falhas de empilhamento em algumas regiões afetadas pelo laser, caracterizadas por faixas paralelas (Figura 5.10.4). 


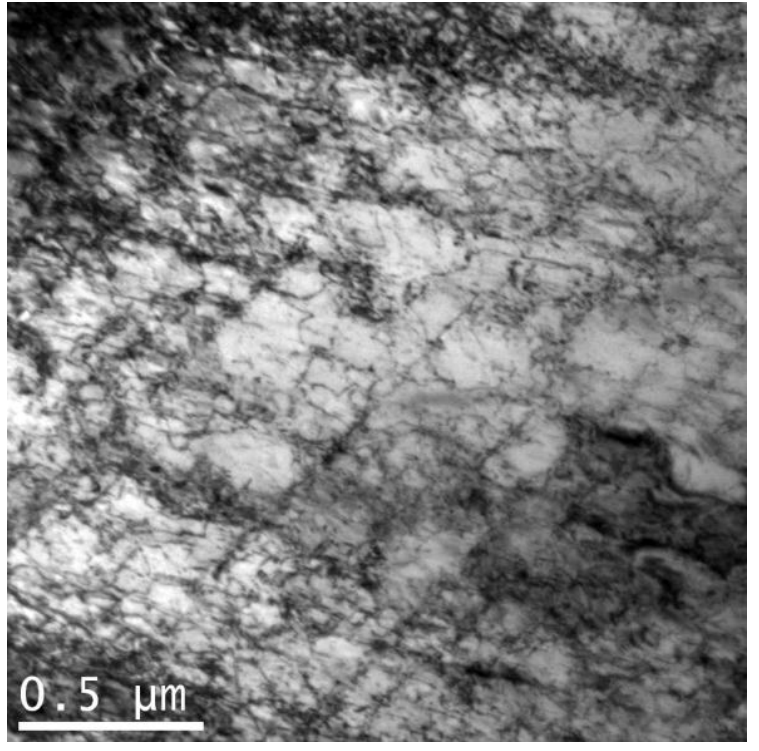

(a)

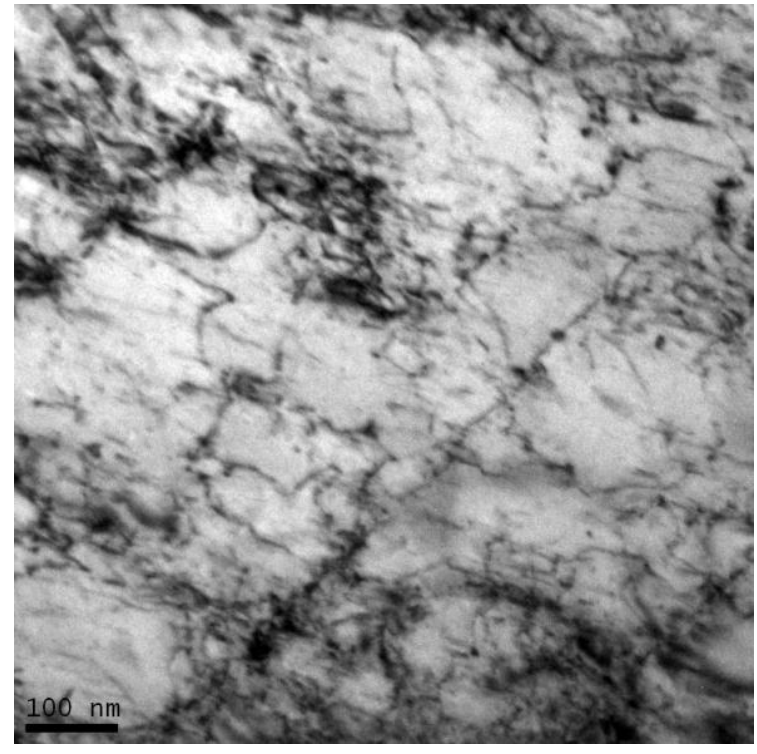

(b)

Figura 5.10.3. Microscopia Eletrônica de Transmissão (MET) do aço inoxidável austenítico ABNT NBR ISO 5832-1, gravado a laser, evidenciando grande densidade de discordâncias.

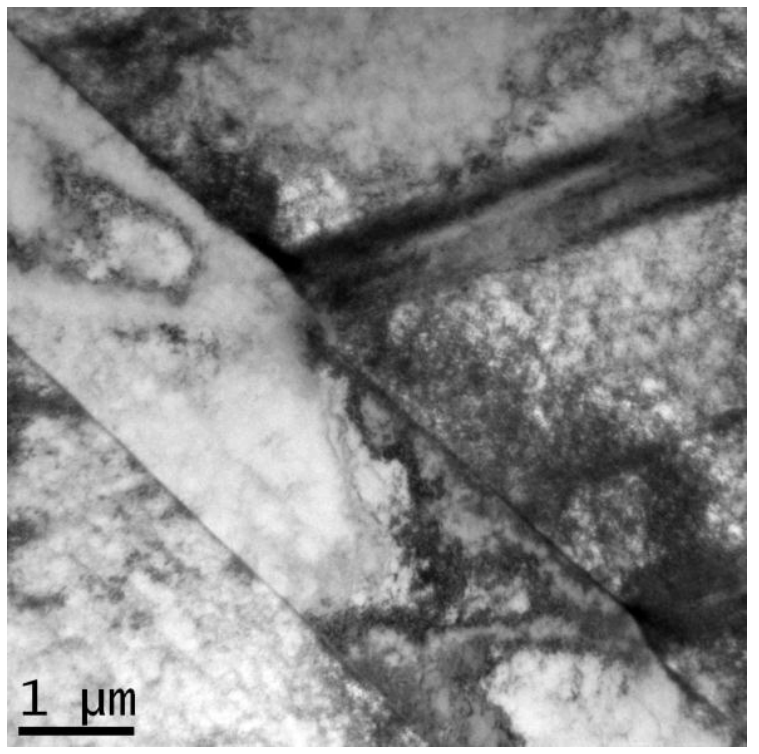

(a)

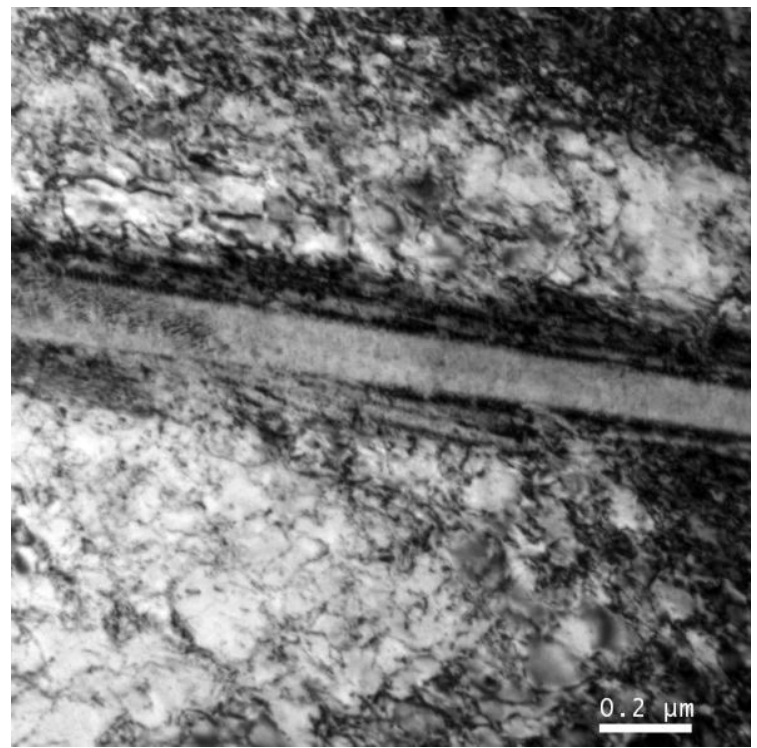

(b) 


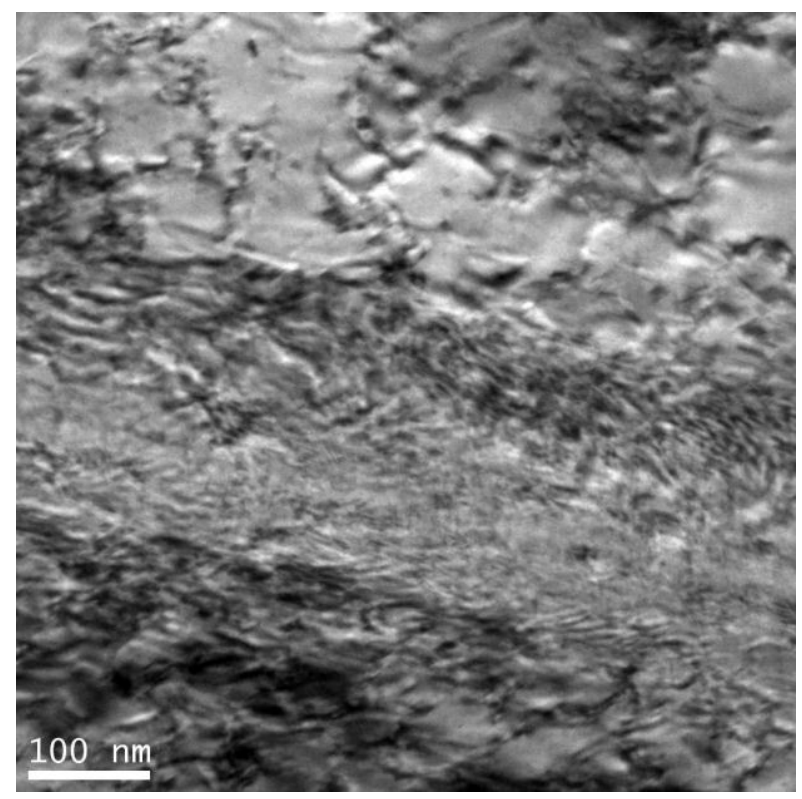

(c)

Figura 5.10.4. Microscopia Eletrônica de Transmissão (MET) do aço inoxidável austenítico ABNT NBR ISO 5832-1, gravado a laser. A faixa encontrada é relacionada à falhas de empilhamento.

Os parâmetros de difração (valores de espaçamento - d) obtidos nas regiões da faixa mostrada na Figura 5.10.4, indicaram que esta se deve a uma fase sigma ( $\mathrm{Fe}-\mathrm{Ni}-\mathrm{Mo})$. A presença desta fase representa a expulsão de $\mathrm{Cr}$ da matriz e a formação de regiões na interface de grande diferença composicional e, portanto, de formação de pilhas, o que favorece o ataque corrosivo na interface.

A Tabela 5.12 apresenta os parâmetros de difração obtidos nas regiões da faixa mostrada na Figura 5.10.4.

Tabela 5.12. Parâmetros de difração obtidos por microscopia eletrônica de transmissão.

\begin{tabular}{|c|c|}
\hline Spot & $\begin{array}{c}\text { Espaçamento }-d \\
(\mathrm{~nm})\end{array}$ \\
\hline 1 & 0,2039 \\
\hline 2 & 0,1728 \\
\hline 3 & 0,1957 \\
\hline 4 & 0,2043 \\
\hline 5 & 0,1724 \\
\hline 6 & 0,1942 \\
\hline
\end{tabular}




\subsection{Mecanismo de Corrosão}

Os resultados exibidos até o presente momento caracterizam o biomaterial utilizado neste estudo, embora não tornem clara a causa da diminuição da resistência, das amostras submetidas à gravação a laser, frente à corrosão por pite. Para se explicar este comportamento, foram realizados novos ensaios de polarização potenciodinâmica cíclica, conforme a norma ABNT NBR 15613-2: 2010 [47], somente com as amostras com gravações a laser, interrompendo-se os mesmos próximos ao potencial de pite; ou seja, acompanhando-se a aquisição dos pontos até o momento em que houve aumento de corrente, indicando a quebra do filme passivo e o surgimento dos primeiros pites de corrosão.

As amostras ensaiadas até este ponto foram limpas com água destilada em ultrassom e suas superfícies analisadas no SEM-FEG. Observou-se a presença de micro-pites ao redor das marcações, tanto nas áreas onde o feixe de raios laser incidiu uma única vez, quanto onde incidiu duas vezes. Nas regiões afetadas pelo laser uma única vez, não houve informações relevantes. Nas regiões duplamente afetadas pelo laser encontrou-se significativa quantidade de inclusões não metálicas, cujas imagens são apresentadas na Figura 5.11.

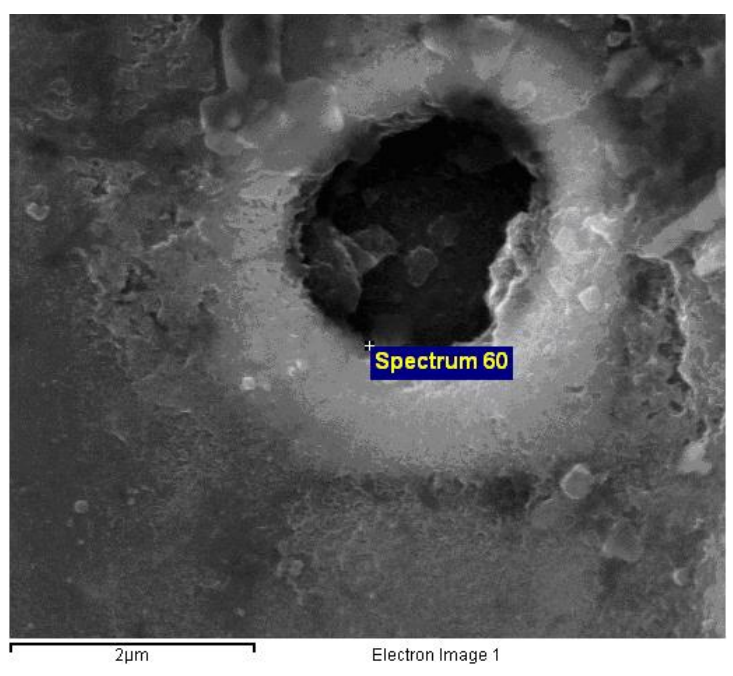

(a)

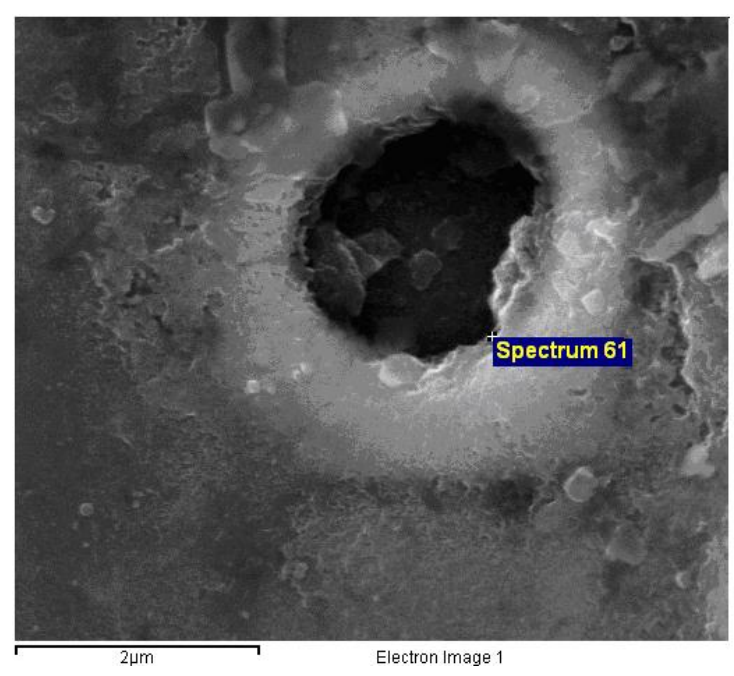

(b) 


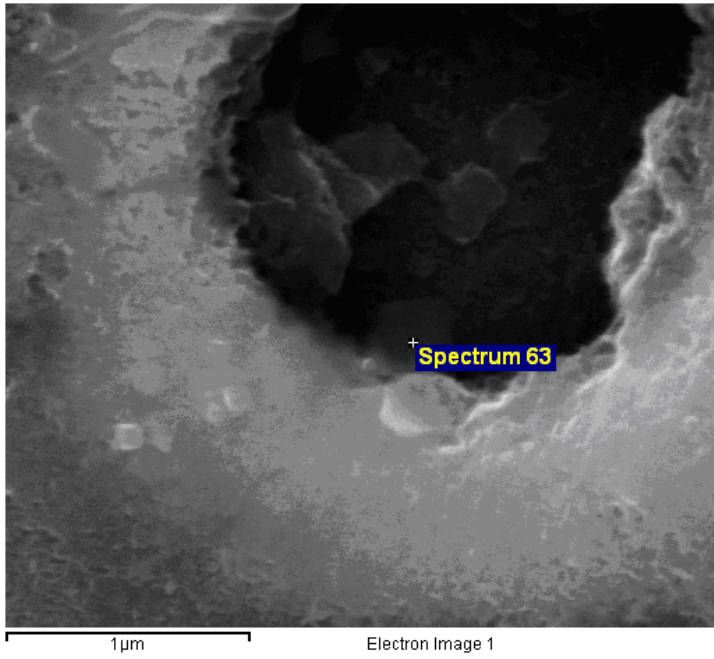

(c)

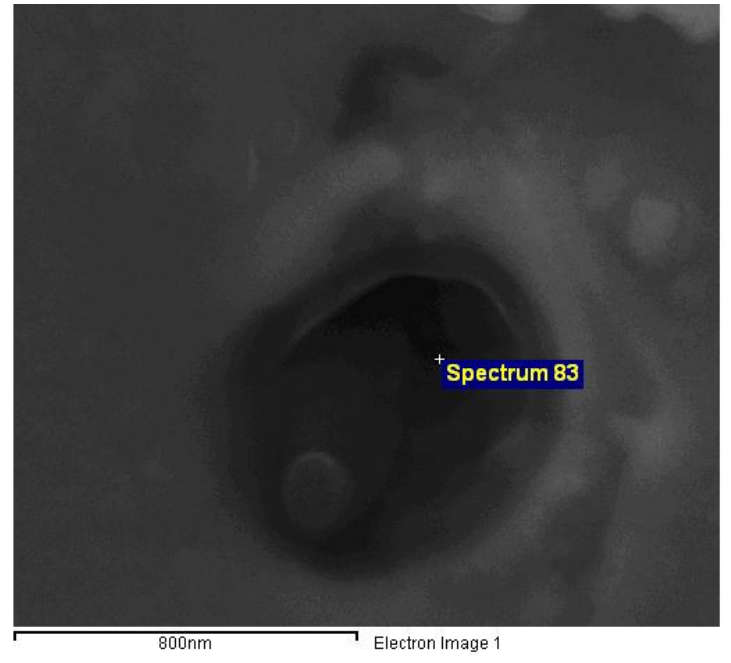

(d)

Figura 5.11. Imagem do interior de um pite nos primeiros estágios de formação indicando a presença de inclusões. Dos pontos selecionados foram feitas análises semiquantitativas.

Nas análises semiquantitativas realizadas nos pontos identificados nas imagens exibidas foram encontradas inclusões não metálicas no interior dos pites nos primeiros estágios de iniciação e propagação. As inclusões observadas são relacionadas à óxidos e carbonetos de alumínio, silício, cálcio, magnésio e manganês. Foram evidenciados traços dos elementos cloro e sódio, decorrentes da solução salina (PBS) utilizada nos ensaios eletroquímicos.

Estes resultados permitem propor um modelo que explique o mecanismo de corrosão deste aço inoxidável submetido à marcações a laser. Foram encontrados pites nas regiões onde o laser incidiu uma única vez, contudo não foi possível detectar a presença de inclusões ao redor.

Nas áreas afetadas duplamente pelo feixe de raios laser, as inclusões, de tamanhos nanométricos conforme exibido nas figuras anteriores, foram reveladas devido à fusão do material que foi depositado nas regiões circunvizinhas, o que produziu um acabamento superficial rugoso, como também já apresentado.

Evidenciaram-se os pites no entorno dessas inclusões, que não sofreram fusão pelo laser, pois são fases cerâmicas, isto é, óxidos e carbonetos, logo possuem ponto de fusão extremamente mais elevado do que as temperaturas geradas no processo de marcação do aço inoxidável.

Entre essas inclusões e a matriz há regiões de frestas de dimensões nanométricas, onde por razões de aeração diferencial inicia-se o mecanismo de corrosão que produziu os pites que foram detectados interrompendo-se os 
ensaios no início do aumento de corrente. Este modelo explica porque as inclusões não haviam sido encontradas após 0 término dos ensaios eletroquímicos de polarização cíclica, uma vez que o processo de corrosão iniciase na interface matriz - inclusão, esta é destacada da matriz, permitindo a visualização apenas do pite. 


\section{DISCUSSÃO GERAL}

Este capítulo de discussão geral visa situar este trabalho no contexto acadêmico mundial, discutindo os resultados anteriormente apresentados, à luz de publicações clássicas e outras mais recentes, que valem como base para estudos nesta área e comprovam o ineditismo desta pesquisa.

O modelo físico adotado para caracterizar eletroquimicamente 0 comportamento do aço inoxidável austenítico usado neste trabalho é apresentado na Figura 6.1. Conforme este modelo e com o que estabelece a literatura [13, 1520] o óxido naturalmente formado sobre o aço inoxidável possui um caráter dúplex, sendo composto por uma camada interna, rica em óxidos de cromo e uma camada externa, rica em óxidos e hidróxidos de ferro.

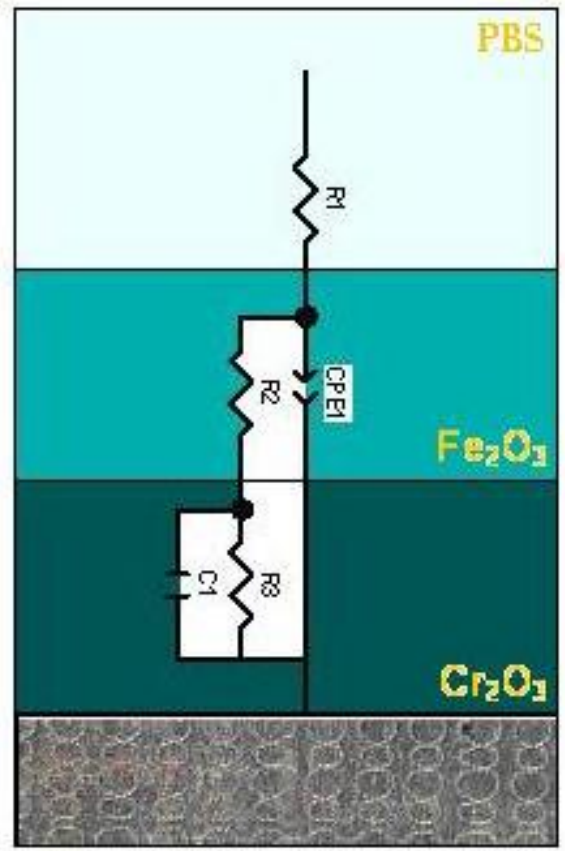

(a)

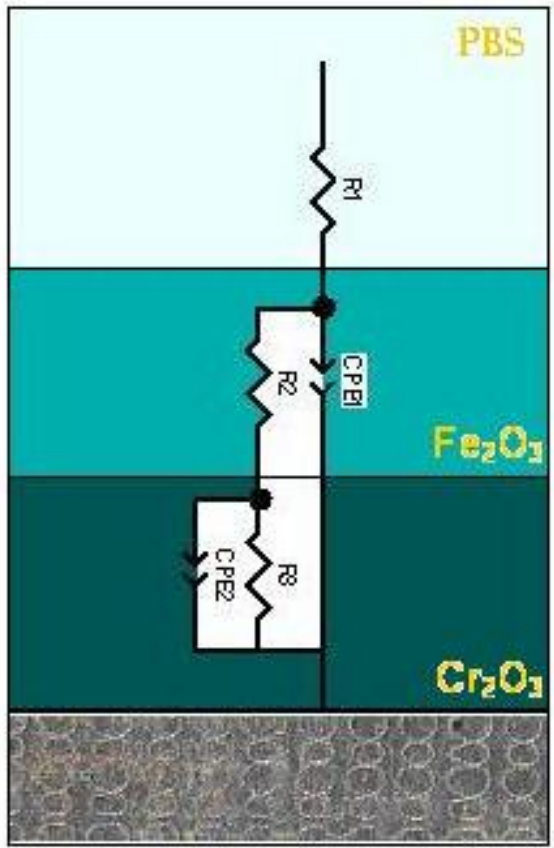

(b)

Figura 6.1. Modelo físico utilizado para representar o comportamento eletroquímico do aço inoxidável austenítico ABNT NBR ISO 5832-1, (a) sem marcações e marcado via laser e, (b) com marcações mecânicas.

Os resultados de EIE foram apoiados pelas curvas de polarização potenciodinâmicas cíclicas. A menor resistência à corrosão por pite foi associada com as amostras com marcações à laser; isto é explicado pelo efeito térmico do processo de marcação via laser sobre a homogeneidade da microestrutura do aço 
inoxidável, o que acaba por diminuir o potencial de quebra da película passiva. A marcação à laser ocorre por fusão da superfície, a fim de produzir a imagem desejada, neste caso, o algarismo oito; acarretando, todavia, em um acabamento superficial muito mais rugoso.

O efeito da rugosidade na resistência à corrosão dos aços inoxidáveis encontra amplo respaldo na literatura. Hong e Nagumo [53] publicaram pesquisa elucidando o efeito da rugosidade superficial nos primeiros estágios de corrosão por pite no aço inoxidável AISI 301 em solução de 0,5M de $\mathrm{NaCl}$ e apresentaram seus resultados em termos de diagramas de impedância e curvas de polarização. Estes pesquisadores lixaram amostras do aço inoxidável AISI 301 em lixas de diferentes granulometrias e, concluiram que o coeficiente de impedância de Warburg, diminuia conforme aumentava-se a numeração da lixa utilizada, ou seja, mais lisa estava a amostra. Eles relacionaram este fato ao número de pites metaestáveis em uma superfície mais lisa ser inferior ao encontrado em superfícies mais rugosas. Segundo estes autores [53], um acabamento superficial mais liso e homogêneo reduz a incidência de pites metaestáveis substancialmente, por reduzir o número de sítios capazes de serem ativados no crescimento metaestável dos pites.

Patrikar [54] realizou pesquisas com o intuito de modelar e simular a rugosidade superficial através de métodos numéricos e do emprego de redes neurais. Inicia seu artigo afirmando que praticamente todas as superfícies na natureza são microscópicamente rugosas, embora pareçam ser lisas a olho nú ou mesmo para muitos microscópios. A rugosidade superficial causa efeitos importantes nas propriedades elétricas dos materiais, como por exemplo, capacitância, condutividade eletrônica, picos no campo elétrico, entre outros. De acordo com Patrikar [54] a resistência elétrica genérica em um filme fino metálico aumenta devido ao espalhamento de elétrons, defeitos pontuais, impurezas e orientação dos grãos; desde que a rugosidade superficial aumente, a resistência elétrica dos filmes finos também aumenta.

Estas pesquisas referenciadas acima confirmam o comportamento apresentado pelas amostras marcadas via raios laser onde foram evidenciadas diminuição na resistência à corrosão, comprovadas pelos modelos sugeridos por circuitos elétricos equivalentes, ou seja, o acabamento superficial implica em mudanças no comportamento eletrônico dos dispositivos. 
Vale lembrar o aparecimento de corrosão por fresta nas amostras marcadas a laser, explicado pela condição da superfície que propiciou condições de aeração diferencial, o que ocorreu de forma não intencional, mas encontra respaldo na literatura no clássico trabalho de Marcel Pourbaix [55] que afirma ser a corrosão por fresta a mais perigosa causa de degradação de biomateriais seja na área de implantes cirúrgicos ou no campo odontológico. Este trabalho aborda um comportamento geral dos biomateriais e não situações específicas.

As marcações executadas por técnica mecânica também implicaram em diminuição da resistência à corrosão por pite do referido aço, quando comparadas ao aço sem gravações; embora de forma não tão acentuada como no caso do laser. No caso da marcação mecânica o efeito não é térmico, mas de deformação, que pode ser considerada equivalente a defeitos na superfície, e os resultados mostraram que estes também diminuem a resistência à corrosão por pite.

Os potenciais de pite para as amostras com marcação a laser são da ordem de 0,6 V enquanto que para aquelas com marcações mecânicas, da ordem de 1,2 V, este último próximo do potencial da reação de evolução do oxigênio (r.e.o). Neste caso, a observação da superfície via MEV e por microscopia óptica, após ensaio de polarização, evidenciou a presença de grande número de pites de corrosão, comprovando que o aumento de corrente foi causado pela quebra localizada do filme passivo.

Antes da quebra do filme são observadas densidades de corrente da ordem de $10^{-6}$ a $10^{-7}\left(\mathrm{~A} \mathrm{~cm}^{-2}\right)$, para as três condições testadas, as quais são típicas de materiais passivos.

Os pites nas amostras com marcação mecânica foram associados à região da marcação, porém em diferentes regiões desta, enquanto que nas amostras com marcação a laser, o maior número de pites ocorreu preferencialmente na região central do oito, onde o laser passou duas vezes.

Os dispositivos médicos implantáveis utilizados nas articulações móveis do corpo humano, bem como os para fins odontológicos requerem biocompatibilidade com os órgãos e tecidos adjacentes, resistência mecânica e, resistência à corrosão. Vale ressaltar que os fluidos corpóreos constituem um ambiente hostil para o implante, que está sujeito também à vários carregamentos. O implante, devido à corrosão, corrosão associada à fadiga e, mesmo ao atrito com ossos e outras partes do corpo humano, pode desprender partículas que, 
entrando em contato com os fluidos corpóreos, são capazes de serem alojadas em locais bem distantes dos de origem causando complicações para os pacientes. Okazaki [45] avaliou as propriedades dos biomateriais metálicos no tocante ao efeito do atrito na polarização anódica.

Em seu trabalho, Okazaki utilizou ligas de titânio, ligas de cobalto e o aço inoxidável SUS 316L. Foi constatado que durante o atrito, as densidades de corrente eram superiores às encontradas em condições estacionárias. Observou também que havia uma faixa de densidade de corrente flutuante, causada pela formação e quebra do filme passivo. Para o aço inoxidável SUS 316L e para as ligas de cobalto, esta flutuação foi observada na região passiva, já para as ligas de titânio, foi observada em ambas as regiões, ativa e passiva. Desta forma, considerou que em um ambiente onde ocorre a possibilidade de atrito, a zona sujeita às maiores tensões é a anódica e sua periferia, catódica.

O meio utilizado por Okazaki [45] foi a solução de Eagle e uma solução contendo $1 \%$ de ácido lático, a $37^{\circ} \mathrm{C}$. Foi constatada uma queda do potencial de corrosão em circuito aberto para o aço inoxidável SUS 316L e para as ligas de cobalto, sob atrito, menor do que a encontrada nas ligas de titânio. Relacionandose estes resultados ao filme passivo, conclui-se que quanto mais estável o filme formado sobre a superfície de um implante, melhor a resistência à corrosão e menor será a desprendimento de íons metálicos destas superfícies.

Analogamente pode-se pensar que nas regiões dos biomateriais metálicos com marcações a laser, por possuírem área superficial maiores, o efeito do atrito também será maior, produzindo micro regiões anódicas nestas áreas e catódicas na periferia. Neste trabalho não foi avaliado o atrito, visto que com o tempo acabaria por remover a marcação, mas o fato do laser aumentar a área e promover um acabamento superficial menos homogêneo aumenta a susceptibilidade à corrosão do material.

No trabalho publicado por Dowling et al. [56] foi avaliado o aço inoxidável ferrítico UNS S44400 quanto sua resistência à corrosão em uma solução de 3,5\% de $\mathrm{NaCl}$, desaerada, a temperatura de $35^{\circ} \mathrm{C}$. Os resultados apontaram que os pites de corrosão encontrados estavam intimamente relacionados ao tipo, quantidade, e tamanho de inclusões intermetálicas presentes na matriz. Para identificar a origem dos pites neste aço inoxidável ferrítico, estes pesquisadores realizaram ensaios curtos de polarização cíclica em amostras polidas, 
interrompendo-os ao primeiro sinal de quebra do filme passivo. Eles encontraram inclusões de óxidos de cromo e alumina, bem como inclusões que os pesquisadores [56] denominaram mais complexas, de sulfeto de manganês e de dióxido de silício, onde foi evidenciada a corrosão por frestas entre estas inclusões e a matriz.

Mecanismo semelhante foi encontrado no aço inoxidável austenítico com marcações via raios laser utilizado neste estudo, onde a origem dos pites de corrosão somente foi constatada realizando-se ensaios de polarização mais curtos, interrompendo-os aos primeiros sinais de quebra da película passiva. Com a análise da superfície via SEM-FEG, pode ser diagnosticada a presença de inclusões que proporcionavam a formação de micro ou nano frestas entre o metal da matriz e as mesmas.

A fim de se determinar as propriedades eletrônicas dos filmes passivos formados sobre os aços inoxidáveis, a literatura [13,16-25] emprega a abordagem de Mott-Schottky. Os resultados de Mott-Schottky são apresentados como o inverso do quadrado da capacitância $(C)$ que é função do potencial $(E)$, conforme a Figura 6.2 mostra.

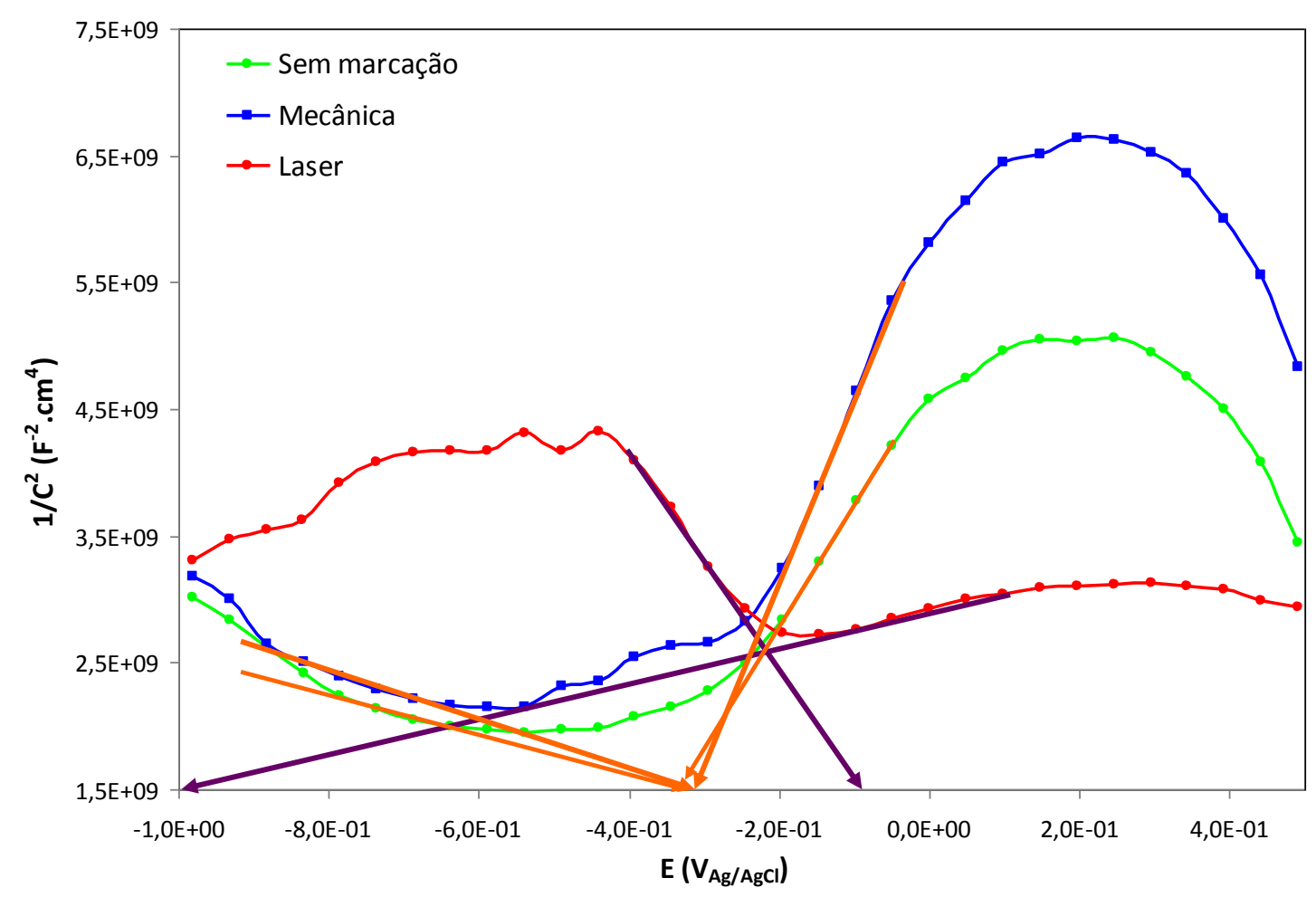

Figura 6.2. Diagrama de Mott-Schottky para as três condições estudadas. As setas nas cores laranja e roxa indicam os potenciais de banda plana $\left(E_{\mathrm{bp}}\right)$, nas amostras com marcações mecânicas e sem marcações e, marcadas a laser, respectivamente. 
A análise dos diagramas de Mott-Schottky evidencia características eletrônicas do filme passivo dependentes do tipo de marcação usado. Esta figura indica características bem diferentes entre a amostra marcada via laser e a marcação mecânica. Tanto para esta última como para as amostras sem marcações, o formato dos gráficos de Mott-Schottky são muito similares, apenas com diferenças na inclinação positiva deste, referente às características de óxido do tipo-n. A marcação a laser resultou em gráficos muito diversos dos comumente obtidos para aços inoxidáveis em meios que simulam os fluidos fisiológicos. Observa-se grande variação no potencial de banda plana, que no caso da marcação a laser ocorreu em potenciais da ordem de $-0,1 \mathrm{~V}$, enquanto para a marcação mecânica ou sem marcação, este foi da ordem de $-0,3 \mathrm{~V}$. Além de causar variação no potencial de banda plana, a marcação a laser causou mudanças em ambas as inclinações, negativa e postiva, ou seja, modificação nas propriedades eletrônicas dos dois tipos de semicondutor, os do tipo-n e do tipo-p, normalmente observados nos filmes passivos de aços inoxidáveis. Vale ressaltar que a marcação a laser resulta em altas temperaturas localizadas, e estas podem alterar significativamente a composição química da superfície, localizadamente.

No estudo publicado por Hakiki et al. [19], que avaliou a estrutura eletrônica dos filmes passivos formados sobre o aço inoxidável AISI 304 e ligas de ferrocromo através da técnica de Mott-Schottky apoiada por espectroscopia de elétrons Auger; foi constatada a influência do cromo sobre o comportamento da capacitância do referido aço inoxidável. Aumentando-se o teor de cromo, a inclinação das curvas de capacitância que respondiam como um semicondutor do tipo-p também aumentava; contudo este aumento do teor de cromo não influenciava a resposta da capacitância, no que se referia ao semicondutor do tipo-n; o que concorda com o fato do filme passivo apresentar caráter dúplex, sendo formado por regiões mais internas formadas por óxidos de cromo e, externas, formadas por óxidos e hidróxidos de ferro; possibilitando, todavia, a comparação do filme passivo com uma heterojunção p-n.

Analogamente, Feng et al. [57] avaliaram as propriedades semicondutoras do filme passivo formado sobre o aço inoxidável austenítico $316 \mathrm{~L}$ em solução tamponada de borato de $\mathrm{pH} \mathrm{9,0} \mathrm{a} 22^{\circ} \mathrm{C}$, utilizando a abordagem de Mott-Schottky, espectrometria de absorção atômica e técnicas de XPS para análise de composição química. Os resultados de espectroscopia de impedância 
eletroquímica (EIE) foram apresentados pelos diagramas de Nyquist e de Bode (log de Z) e ajustados com circuitos elétricos equivalentes (CEEs). Neste trabalho também estimaram a espessura dos filmes passivos, que apresentou variação de acordo com o potencial obtido pelas curvas de polarização. Os valores obtidos para as densidades de defeitos nos óxidos levaram em consideração o efeito da área, de acordo com as equações 7 e 8, para os semicondutores tipo-n e tipo-p, respectivamente.

$$
\begin{aligned}
& \frac{1}{C^{2}}=\frac{2}{\varepsilon \varepsilon_{0} e N_{d} A^{2}}\left(E-E_{\mathrm{b}_{\mathrm{P}}}-k T / e\right) \quad \text { tipo-n } \\
& \frac{1}{C^{2}}=-\frac{2}{\varepsilon \varepsilon_{0} e N_{a} A^{2}}\left(E-E_{\mathrm{b}_{\mathrm{P}}}-k T / e\right) \quad \text { tipo-p }
\end{aligned}
$$

O efeito da área, embora não empregado neste trabalho, que considerou área unitária limitada pelo "o-ring", pode explicar, em parte, os resultados obtidos pela técnica de Mott-Schottky para amostras com marcação a laser, por estas apresentarem maior rugosidade superficial, o que aumenta efetivamente a área analisada.

O trabalho publicado por Bastos et al. [58] utilizou a técnica SVET para mapear as correntes iônicas em um aço ao carbono recoberto por camada fina de zinco. Foram produzidos defeitos superficiais manualmente e a análise foi realizada após oito dias de imersão em solução de $5 \mathrm{mM}$ de $\mathrm{NaCl}$. Os mapas de correntes iônicas obtidos via SVET mostraram que um defeito era predominantemente anódico (correntes positivas) e o outro, catódico (correntes negativas), foi registrada maior atividade dos íons $\mathrm{Zn}^{+2}$ na região anódica e menor na região catódica; o que foi explicado pelo aumento do $\mathrm{pH}$ na proximidade do defeito catódico, onde os cátions do zinco foram precipitados e a atividade era menor comparando-se com as outras áreas da solução.

Fato semelhante ocorreu com as amostras do aço inoxidável austenítico marcado a laser, onde nas regiões de micro ou nano frestas há queda acentuada no $\mathrm{pH}$, tornando-as mais susceptíveis à corrosão. Estas regiões foram detectadas como áreas anódicas (correntes positivas) pela técnica SVET; que são as zonas onde se inicia a corrosão localizada. 
Pesquisa semelhante foi publicada por Lamaka et al. [59] sobre o monitoramento de cátions $\mathrm{Mg}^{2^{+}}, \mathrm{pH}$ e correntes iônicas em uma liga a base de magnésio em solução aquosa de $0,05 \mathrm{M}$ de $\mathrm{NaCl}$. Eles utilizaram as técnicas SVET e SIET (scanning ion-selective electrode technique) por tratarem-se de métodos mais localizados para se determinar, in situ, zonas ativas, poros ou defeitos singulares restritos a pequenas regiões. Foi constatado que as regiões catódicas correspondiam à reação de redução, com a alcalinização local da solução até $\mathrm{pH} 8,5$, que foi medido via SIET usando um "eletrodo-pH". Nas regiões anódicas observaram queda do $\mathrm{pH}$ para 5,3, o que foi relacionado à dissolução e hidrólise do magnésio. Os resultados permitiram o conhecimento das atividades locais das reações químicas que aconteciam nos micro defeitos.

Kallip et al. [60] valeram-se da técnica SVET para monitoramento das correntes, anódicas e catódicas, localizadas em uma célula contendo fios metálicos de $\mathrm{Fe}, \mathrm{Al}, \mathrm{Zn}, \mathrm{Cu}, \mathrm{Mg}$ e do aço inoxidável austenítico 316L, adicionando inibidores de corrosão ao eletrólito de $0,05 \mathrm{M}$ de $\mathrm{NaCl}$. Desta forma, para cada metal, eles conseguiram acompanhar a evolução em espaço e tempo, dos processos anódicos e catódicos. Após seis horas de imersão os metais que se apresentaram mais ativos foram $\mathrm{Mg}, \mathrm{Zn}$ e Fe; nos outros metais não foi detectado atividade. Algumas publicações utilizando a técnica SVET necessitam de um olhar crítico, pois estudam materiais com comportamentos bem dispares.

Comportamento similar foi obtido nas amostras de aço inoxidável austenítico marcadas via raios laser, após alguns períodos de imersão, onde observou-se diminuição da atividade evidenciada pela queda nos valores de correntes anódicas.

Um dos entraves encontrados no decorrer desta pesquisa foi a escassez de literatura sólida sobre o efeito das marcações a laser sobre o aço inoxidável. Alguns artigos [61,62] requerem discussão mais apurada no que se refere à influência dos parâmetros de marcação sobre características como o contraste, o brilho e a rugosidade.

Gil et al. [63] estudaram a influência da marcação a laser em biomateriais produzidos em titânio e Ti-6Al-4V em seu comportamento mecânico e eletroquímico. Foi utilizada uma solução que simulava os fluidos corpóreos a $37^{\circ} \mathrm{C}$, e foram realizadas polarizações cíclicas e ensaios de fadiga. As amostras submetidas às marcações a laser apresentaram menores valores de resistência à 
corrosão e de resistência à fadiga. Este comportamento foi relacionado, pelos pesquisadores, às mudanças microestruturais, tais como: diminuição do tamanho de grão na zona fundida e tensões residuais que favoreceriam o decréscimo da resistência à corrosão. A queda na resistência à corrosão associada à fadiga foi relacionada à microestrutura martensítica e às tensões residuais. 


\section{CONCLUSÕES}

Os resultados do presente trabalho permitem concluir que:

A técnica de marcação a laser de biomateriais metálicos tem efeito deletério na resistência à corrosão localizada, aumentando a susceptibilidade à corrosão por pite nas condições utilizadas. A marcação a laser altera as características do filme passivo, revela sulcos na superfície, causa o arrancamento de grãos e, estas contribuem para a diminuição na resistência à corrosão localizada do biomaterial. A técnica de marcação mecânica também implica em diminuição da resistência à corrosão por pite.

Alguns dos efeitos da marcação via raios laser são aumento de rugosidade devido à fusão da superfície das mesmas, formação de uma interface entre a zona fundida e a matriz com elevada densidade de discordâncias comprovada por microscopia eletrônica de transmissão a qual foi também evidenciada pelo etch pit, na região. Além disso, na região afetada pelos raios laser ocorreu enriquecimento de cromo na região onde o feixe de laser incidiu duplamente, conforme as análises de SEM-FEG e EDS indicaram. Nesta região também foram observados precipitados tanto de carboneto de cromo quanto de óxidos de silício e de alumínio.

A maior quantidade de pites de corrosão foi encontrada no centro da região do algarismo oito nas amostras marcadas a laser. A análise semiquantitativa destas regiões, ao se interromperem os ensaios eletroquímicos aos primeiros sinais de quebra da película passiva, diagnosticou inclusões de óxidos nesta região que foram colocadas em relevo pela dupla incidência do feixe de laser causando fusão na região embora não a fusão das inclusões de óxidos. $O$ ataque da matriz de aço em volta das inclusões de óxidos promove a formação de micro frestas entre esta e as inclusões que favorecem o crescimento do pite. Este é o mecanismo proposto para explicar a maior susceptibilidade à corrosão localizada nas áreas afetadas pela marcação a laser.

A abordagem de Mott-Schottky mostrou-se bastante sensível para identificar o efeito do tipo de gravação na resistência à corrosão por pite. As curvas de $1 / \mathrm{C}^{2}$ versus $E$ evidenciaram que o óxido formado sobre a superfície do aço inoxidável austenítico possui caráter dúplex na solução utilizada, ou seja, acima do potencial de banda plana ele comporta-se como um semicondutor tipo-n 
e abaixo deste potencial, como um semicondutor tipo-p. Desta forma, esta técnica mostrou-se capaz de identificar as propriedades eletrônicas do filme passivo.

A técnica SVET comprovou que as regiões marcadas a laser são as mais propensas ao início da corrosão localizada por apresentarem as maiores densidades de correntes anódicas.

Através da técnica de microscopia eletrônica de transmissão (MET) detectou-se elevada densidade de discordâncias, falhas de empilhamento e precipitados não-metálicos no interior do aço marcado a laser. Também pôde ser evidenciada a presença de uma fase inesperada, que foi verificada pelos parâmetros de difração como uma fase sigma ( $\mathrm{Fe}-\mathrm{Ni}-\mathrm{Mo})$.

Entre as duas técnicas de marcações de biomateriais metálicos avaliadas neste trabalho, indica-se a mecânica por apresentar menor susceptibilidade à corrosão do que a marcação a laser. 


\section{SUGESTÕES PARA TRABALHOS FUTUROS}

1. Análise de densidade de discordâncias geradas pela técnica de marcação a laser, correlacionando-as com as encontradas no material sem marcações.

2. Caracterização do comportamento eletroquímico do material variando-se os parâmetros da técnica de marcações a laser.

3. Análise dos filmes passivos formados sobre o material empregando-se as técnicas de XPS e AES.

4. Caracterização do material, com e sem marcações, através da técnica de microdifração de raios- $X$.

5. Realização de ensaios de fadiga e corrosão-fadiga em amostras do material com marcações a laser, mecânicas e sem marcações.

6. Caracterização do comportamento eletroquímico do material, com e sem marcações, em soluções fisiológicas contendo proteínas. 


\section{APÊNDICE}

EIS_Laser1a_marcação.txt

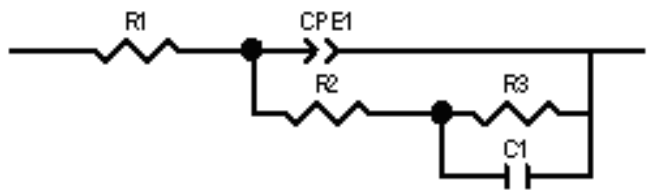

\begin{tabular}{|c|c|c|c|c|}
\hline Element & Freedom & Value & Error & Emor \% \\
\hline R1 & Free(+) & 42,84 & 0,13732 & 0,32054 \\
\hline CPE1-T & Free(+) & 0,00015435 & $1,4009 E-6$ & 0,90761 \\
\hline CPE1P & Free $(+)$ & 0,86162 & 0,0015829 & 0,18371 \\
\hline $\mathrm{R} 2$ & Free(+) & 81,36 & 5,6767 & 6,9773 \\
\hline R3 & Free(+) & $4,2592 \mathrm{E} 5$ & 20358 & 4,7798 \\
\hline C1 & Free(+) & $3,4153 \mathrm{E}-5$ & $1,3275-6$ & 3,8869 \\
\hline \multicolumn{2}{|c|}{ Chi-Squared } & \multicolumn{3}{|l|}{0,00050559} \\
\hline \multicolumn{2}{|c|}{ Weignted Sum of Squares: } & \multicolumn{3}{|l|}{0,054604} \\
\hline \multicolumn{2}{|c|}{ Data File: } & \multicolumn{3}{|c|}{ CiUsersi DesktopiCE E'EIS_Laser1a_com_I } \\
\hline \multicolumn{2}{|c|}{ Circut Model File: } & \multicolumn{3}{|c|}{ C:Users DesktopiCE E'Eurico Model Iaser. } \\
\hline \multicolumn{2}{|c|}{ Mode: } & \multicolumn{3}{|c|}{ Run Fitting / Freq. Range $(0,001-1000000)$} \\
\hline \multicolumn{2}{|c|}{ Maxmum Iterations } & \multicolumn{3}{|c|}{100} \\
\hline \multicolumn{2}{|c|}{ Optimization Iterations: } & \multicolumn{3}{|l|}{0} \\
\hline \multicolumn{2}{|c|}{ Type offitting } & \\
\hline \multicolumn{2}{|c|}{ Type of Wigiglting } & \multicolumn{3}{|c|}{ Calc-Modulus } \\
\hline
\end{tabular}
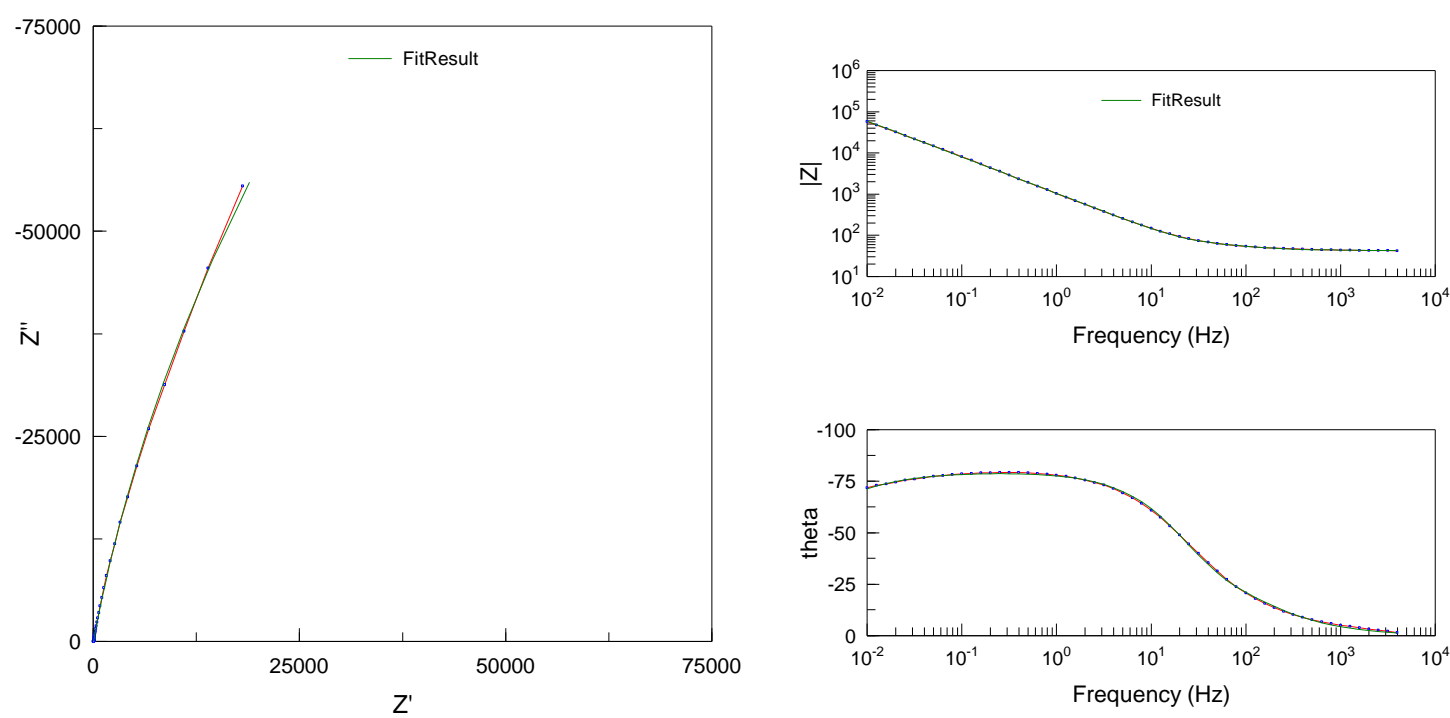
EIS_Sem_marca.txt

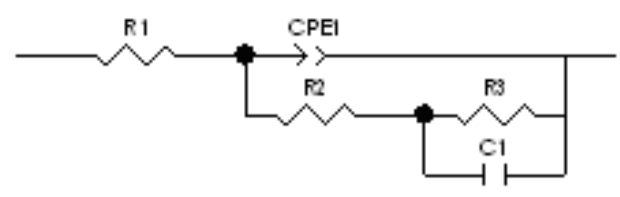

\begin{tabular}{|c|c|c|c|c|}
\hline Element & Freedom & Value & Error & Error $\%$ \\
\hline R1 & Free $(+)$ & $\overline{44,23}$ & $\overline{0,1303}$ & $\overline{0,2946}$ \\
\hline CPE1-T & Free $(+)$ & $2,8345 \mathrm{E}-5$ & $6,8008 \mathrm{E}-8$ & 0,24014 \\
\hline CPE1-P & Free $(+)$ & 0,92156 & 0,00052001 & 0,057176 \\
\hline $\mathrm{R} 2$ & Free $(+)$ & $1,7105 \mathrm{E} 5$ & 18410 & 10,763 \\
\hline R3 & Free $(+)$ & $6,8045 \mathrm{E} 6$ & $7,3097 \mathrm{E} 5$ & 10,831 \\
\hline C1 & Fixed $(x)$ & $2,215 \mathrm{E}-6$ & NA & NA \\
\hline \multicolumn{2}{|c|}{ Chis Squ ared: } & \multicolumn{3}{|l|}{0,0005743} \\
\hline \multicolumn{2}{|c|}{ Wil eighted Sum of Squares: } & \multicolumn{3}{|l|}{0,063747} \\
\hline \multicolumn{2}{|l|}{ Data File: } & \multicolumn{3}{|c|}{ C:UUsersi DesktopiCEE.EIS_sem_m } \\
\hline \multicolumn{2}{|c|}{ Circuit Model File: } & \multicolumn{3}{|c|}{ C:Users' DesktopiCEE,Eurico Model sem } \\
\hline \multicolumn{2}{|l|}{ Mode: } & \multicolumn{3}{|c|}{ Run Fitting / Freq. Range $(0,001-100000)$} \\
\hline \multicolumn{2}{|c|}{ Maximum Iterations: } & \multicolumn{3}{|l|}{100} \\
\hline \multicolumn{2}{|c|}{ Optimization Iterations: } & \multicolumn{3}{|l|}{0} \\
\hline \multicolumn{2}{|c|}{ Type of Fitting: } & \multicolumn{3}{|l|}{ Complex } \\
\hline \multicolumn{2}{|c|}{ Type of 'Neighting: } & \multicolumn{3}{|c|}{ Calo Modulus } \\
\hline
\end{tabular}

Type of 'Nieighting: Calchodulus
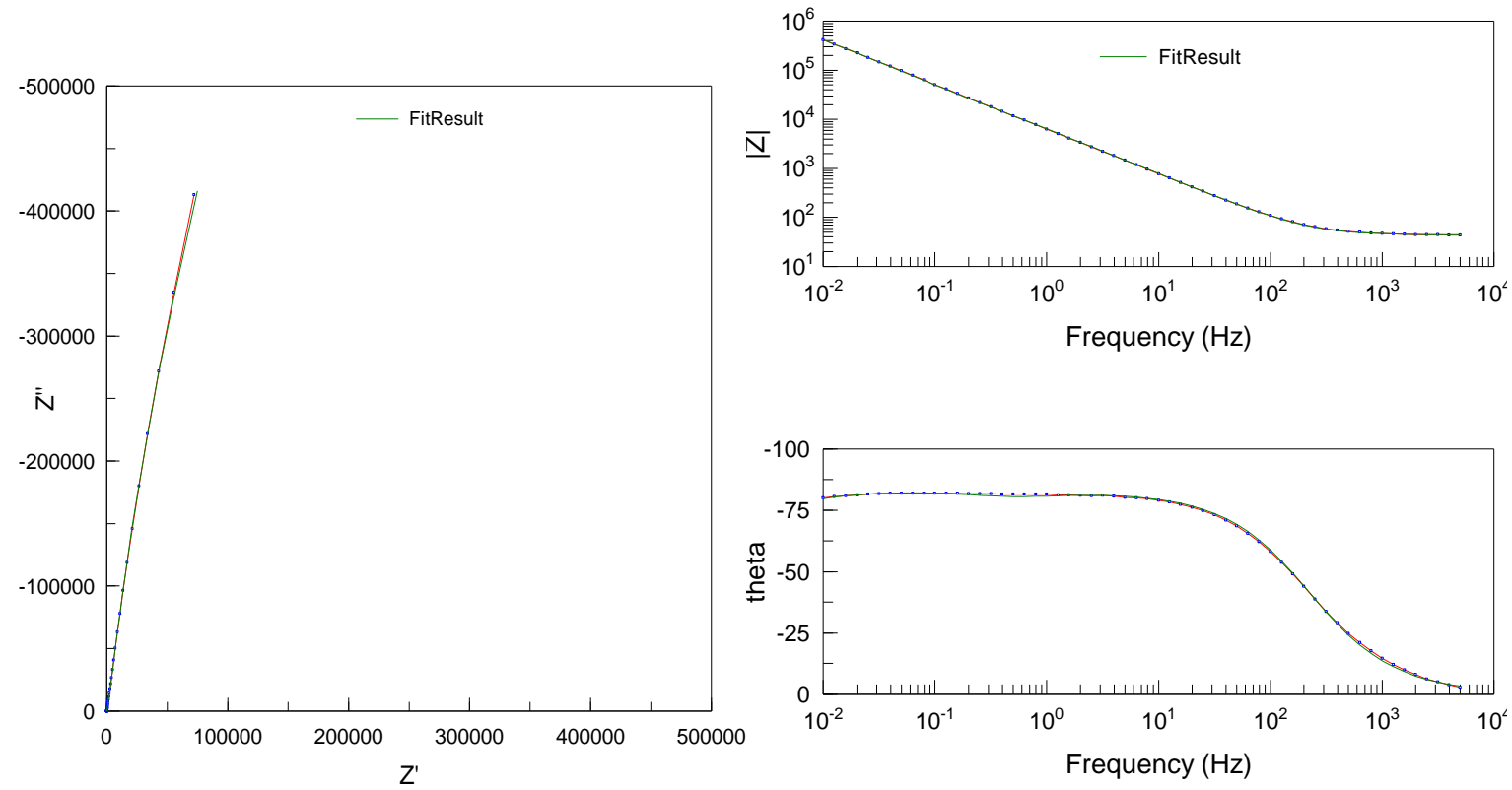
EIE_Mecânica.txt

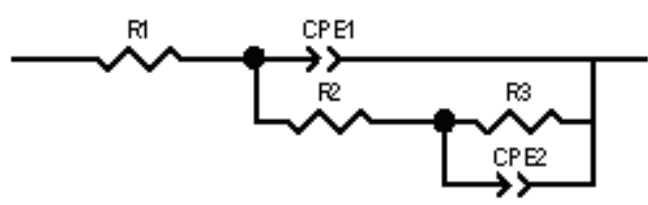

\begin{tabular}{|c|c|c|c|c|}
\hline Element & Freedom & Value & Error & Emor \% \\
\hline R1 & Free(+) & 41,62 & 0,067359 & 0,16184 \\
\hline CPE1-T & Free(+) & $4,248 \mathrm{E}-5$ & $1,078 \mathrm{E}-7$ & 0,25377 \\
\hline CPE1P & Freec(+) & 0,917 & 0,00057241 & 0,062422 \\
\hline $\mathrm{R} 2$ & Free(+) & $2,0838 E 5$ & 10751 & 5,1593 \\
\hline R3 & Free $(+)$ & $1,792 \mathrm{SE} 6$ & 86008 & 4,7982 \\
\hline CPE2-T & Freec(+) & 8,7857 E -6 & $1,933 \mathrm{E}-7$ & 2,2002 \\
\hline CPE2P & Fixed(x) & 0,79641 & NiA & N/A \\
\hline \multicolumn{2}{|c|}{ Chi-Squared } & \multicolumn{3}{|l|}{0,00018216} \\
\hline \multicolumn{2}{|c|}{ Weighted Sum of Squares: } & \multicolumn{3}{|l|}{0,020402} \\
\hline \multicolumn{2}{|c|}{ Data File: } & \multicolumn{3}{|c|}{ C:Usersi DesktopiCEE'EIS_Mecarica1a } \\
\hline \multicolumn{2}{|c|}{ Circuit Model File: } & \multicolumn{3}{|c|}{ C:Usersi DesktopiCEE'Eurico Model meca } \\
\hline \multicolumn{2}{|c|}{ Mode: } & \multicolumn{3}{|c|}{ Run Fitting / Freq. Range $(0,001-1000000)$} \\
\hline \multicolumn{2}{|c|}{ Maximum Iterations } & \multicolumn{3}{|l|}{100} \\
\hline \multicolumn{2}{|c|}{ Optimization Iterations } & \multicolumn{3}{|l|}{0} \\
\hline \multicolumn{2}{|c|}{ Type offitting } & \multicolumn{3}{|l|}{ Complex } \\
\hline \multicolumn{2}{|c|}{ Type of Weigting } & \multicolumn{3}{|c|}{ Calc-Modulus } \\
\hline
\end{tabular}
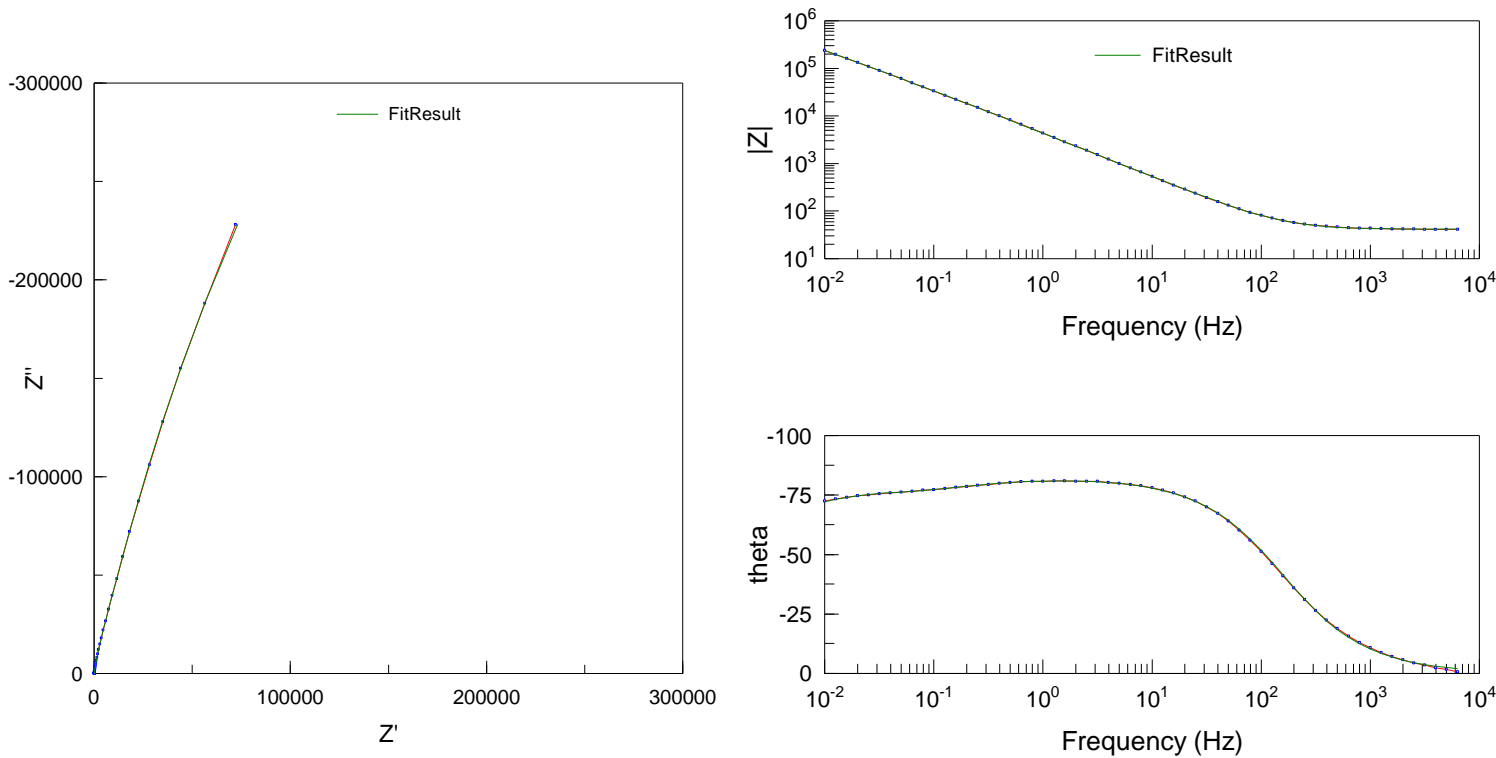


\section{REFERÊNCIAS BIBLIOGRÁFICAS}

[1] LYMAN,D.J., SEARE, Jr,W.J.,Biomedical materials in surgery, Materials Science, v.4, p. 415-433,1974.

[2] WILLIAMS, D.F., Corrosion of implant materials, Materials Science, v.6, p. 237266, 1976.

[3] GIBBONS, D.F., Biomedical materials, Biophisics and Bioengineering, v. 4, p. 367-375, 1975.

[4] HENCH, L.L., Prosthetic implant materials, Materials Science, v.5, p.279-300, 1975.

[5] ANDERSON, J. M., Biological response to materials, Materials Research, v. 31, p. 81-110, 2001.

[6] OLIVEIRA, L.P., PENTEADO, L.O.S., et.al.,Análise química e estrutural de implantes ortopédicos de aço inoxidável, Revista Brasileira de Ortopedia, 2004.

[7] VILLAMIL, R.F.V., ARANHA, H., AFONSO, M.L.C. de A., MERCADANTE, M.T., AGOSTINHO, S.M.L.: Aços inoxidáveis em implantes ortopédicos: fundamentos e resistência à corrosão. Revista Brasileira de Ortopedia, v. 37, 471476, 2002.

[8] GIORDANI, E.J., FERREIRA, I., BALANCIN, O., Propriedades mecânicas e de corrosão de dois aços inoxidáveis austeníticos utilizados na fabricação de implantes ortopédicos. REM - Revista da Escola de Minas, v. 60, n.1, p.55-62, 2007.

[9] POURBAIX, M., KLIMZACK-MATHIEU, L., MERTERNS, C., MEUNIER, J., VANLUEGEN-HAGHE, C., de MUNCK, L., LAUREYS, J., NEELEMANS, L., WARZEE, M., Potentionkinectic and corrosimetric investigations of the corrosion behavior of alloy steels, Corrosion Science, v. 3, p. 239-259, 1963.

[10] ABNT NBR 12932: 2010, Implantes para cirurgia - Materiais metálicos Preparação de superfície e marcação.

[11] VERMILYEA, D.A., Corrosion science, Materials Science, p.373-398, 1971.

[12] MARCUS, P., Surface science approach of corrosion phenomena, Electrochemica Acta, v.43, n1/2, p. 109-118, 1998.

[13] HAKIKI, N.E., Da CUNHA BELO,M., SIMÕES, A.M.P., FERREIRA, M.G.S., Semiconducting properties of passive films formed on stainless steels, $J$. Electrochem. Soc. v. 145, p. 3821-3829, 1998. 
[14] CASTLE,J.E., CLAYTON, C.R., The use of x-ray photo-electron spectroscopy in the analyses of passive layers on stainless steel, Corrosion Science, v. 17, p. 726, 1977.

[15] CALLISTER Jr,W.D., Ciência e Engenharia de Materiais: Uma Introdução, Rio de Janeiro, LTC, 2002.

[16] HAKIKI, N.E., MONTEMOR, M.F., FERREIRA,M.G.S., Da CUNHA BELO,M., Semiconducting properties of thermally grown oxide films on AISI 304 stainless steel, Corrosion Science, v.42, p. 687-702, 2000.

[17] Da CUNHA BELO, M., HAKIKI, N. E., M, FERREIRA, M.G.S., Semiconducting properties of passive films formed on nickel-base alloys type Alloy 600: influence of the alloying elements, Electrochimica Acta, v.44, pp.2473$2481,1999$.

[18] TAVEIRA, L. V., MONTEMOR, M. F., Da CUNHA BELO, M., FERREIRA, M. G., DICK, L. F.P., Influence of incorporated $\mathrm{Mo}$ and $\mathrm{Nb}$ on the Mott-Schottky behaviour of anodic films formed on AISI 304L, Corrosion Science, v. 52, pp.2813-2818, 2010.

[19] HAKIKI, N. E., BOUDIN, S., RONDOT, B., Da CUNHA BELO, M., The electronic structure of passive films formed on stainless steels, Corrosion Science, v.37, p. 1809-1822, 1995.

[20] SCHMUKI, P., BÖHNI, H., BARDWELL, J.A., In situ characterization of anodic silicon oxide films by ac impedance measurements, Journal of the Electrochemical Society, v. 142, p. 1705-1712, 1995.

[21] MONTEMOR, M.F., Ferreira, M.G.S., HAKIKI, N.E., Da CUNHA BELO, M., Chemical composition and electronic structure of the oxide films formed on 316 $\mathrm{L}$ stainless steel and nickel based alloys in high temperature aquous environments, Corrosion Science, v. 42, p. 1635-1650, 2000.

[22] TOOR, I., Mott-Schottky analysis of passive films on Si containing stainless steel alloys, J. Electrochem. Soc., v.158, p. C391-C395, 2011.

[23] DAROWICKI, K., KRAKOWIAK, S., SLEPSKI, P., Selection of measurement frequency in Mott-Schottky analysis of passive layer on nickel, Electrochimica Acta, v. 51, p. 2204-2208, 2006.

[24] GUO, H. X., LU, B. T., LUO, J. L., Study on passivation and erosionenhanced corrosion resistance by Mott- Schottky analysis, Electrochimica Acta, v. 52, 1108-1116, 2006.

[25] PYUN, S., KIM, C., Determination of donor concentrarion in anodically passivating polycrystalline $\mathrm{TiO}_{2}$ films from analysis of nonlinear Mott-Schottky plots, Int. J. Hydrogen Energy, v. 16, p. 661-664, 1991. 
[26] BONORA, P. L., DEFLORIAN, F., FEDRIZZI, L., Electrochemical impedance spectroscopy as a tool for investigating underpainting corrosion, Electrochemica Acta, v. 41, p. 1073-1082, 1996.

[27] MARTINI, E. M. A., MULLER, I. L., Characterization of the film formed on iron in borate solution by electrochemical impedance spectroscopy, Corrosion Science, v. 42, n.3, p. 443-454, 2000.

[28] LIU, C., Bi, Q., LEYLAND, A., MATTHEWS, A., An electrochemical impedance spectroscopy study of the corrosion behavior of PVD coated steels in 0,5N NaCl aqueous solution, Part I, Corrosion Science, v.45, p. 1243-1256, 2003.

[29] SOUTO, R. M., LAZ, M. M., REIS, R. L., Degradation characteristics of hydroxiapatite coatings on orthopaedic TiAIV in simulated physiological media investigated by eletrochemical impedance spectroscopy, Biomaterials, v. 24, p. 4213-4221, 2003.

[30] MANSFELD, F., SHIH, H., Detection of pitting with electrochemical impedance spectroscopy, J. Electrochem. Soc., p. 1171-1172, 1988.

[31] TRETHEWEY, K. R., PATON, M., Electrochemical impedance behaviour of type 304L stainless steel under tensile loading, Materials Letters, v. 58, p. 33813384, 2004.

[32] KRAKOWIAK, S., DAROWICKI, K., SLEPSKI, P., Impedance investigation of passive 304 stainless steel in the pit pre-initiation state, Electrochemica Acta, v. 50, p. 2699-2704, 2005.

[33] MANSFELD, F., Electrochemical impedance spectroscopy (EIS) as a new tool for investigating methods of corrosion protection, Electrochemica Acta, v. 35, p. 1533-1544, 1990.

[34] JI, J., TAN, Q., FAN, D., SUN, F., BARBOSA, M. A., SHEN, J., Fabrication of alternating polycation and albumin multilayer coating onto stainless steel by electrostatic layer-by-layer adsorption, Colloids and Surfaces B: Biointerfaces, v.34, p. 185-190, 2004.

[35] ALVES, V. A., REIS, R. Q., SANTOS, I. C. B., SOUZA, D. G., GONÇALVES, T., PEREIRA, M. A., ROSSI, A., SILVA, L.A., In situ impedance spectroscopy study of the eletrochemical corrosion of $\mathrm{Ti}$ and $\mathrm{Ti}-6 \mathrm{Al}-4 \mathrm{~V}$ in simulated body fluid at 25ํㅡ $\mathrm{C}$ and $37^{\circ} \mathrm{C}$, Corrosion Science, v. 51, p. 2473-2482, 2009.

[36] ZOSKI, C. G., Ultramicroelectrodes: Design, fabrication, and characterization, electroanalysis, v.14. p. 1041-1051, 2002.

[37] ISAACS, H. S., The measurement of the galvanic corrosion of soldered copper using the scanning vibrating electrode technique, Corrosion Science, v.28, p 547-558, 1988. 
[38] WIPF, D. O., WIGHTMAN, R. M., Submicrosecond measurements with cyclic voltammetry, Analytical Chemistry, v.60, p. 2460-2464, 1988.

[39] WIPF, D. O., WIGHTMAN, R. M., Voltammetry with microvoltammetric electrodes in resistive solvents under linear diffusion conditions, Analytical Chemistry, v. 62, p.98-102, 1990.

[40] BARD, A. J., FAN, F. F., KWAK, J., LEV, O., Scanning electrochemical microscopy. Introduction and principles, v. 61, p. 132-138, 1989.

[41] JAFFE, L. F., NUCCITELLI, R., An ultrasensitive vibrating probe for measuring steady extracellular currents, The Journal of Cell Biology, v. 63, p. 614628, 1974.

[42] ISAACS, H. S., The effect of height on the current distribution measured with a vibrating electrode probe, Journal of Electrochemical Society, v. 138, p. 722-727, 1991.

[43] VUILLEMIN, B., PHILIPPE, X., OLTRA, R., VIGNAL, V., COUDREUSE, L., DUFOUR, L. C., FINOT, E., SVET, AFM and AES study of pitting corrosion initiated on MnS inclusions by microinjection, Corrosion Science, v. 45, p. 11431159, 2003.

[44] TRINH, D., MAISONHAUTE, E., VIVIER, V., Electrical cross-talk in transient mode of scanning electrochemical microscopy, Electrochemistry Communications, v. 16, p. 49-52, 2012.

[45] OKASAKI, Y., Effect of friction on anodic polarization properties of metallic biomaterials, Biomaterials, v.23, p. 2071-2077, 2002.

[46] BORRUTO, A., TARASCHI, I., Wear dependence on some factors characterizing the surface state: the hardness, the roughness and the surface degreasing, Wear, v. 184, p. 119-124, 1995.

[47] ABNT NBR 15613-2: 2010, Implantes para cirurgia - Resistência à corrosão Parte 2: Determinação de suscetibilidade à corrosão de pequenos componentes Medida de polarização potenciodinâmica cíclica.

[48] AHN, S.J., KWON, H. S., Effects of solution temperature on electronic properties of passive film formed on $\mathrm{Fe}$ in $\mathrm{pH} 8.5$ borate buffer solution, Electrochimica Acta, v. 49, p. 3347-3353, 2004.

[49] BASTOS, A.C., KARAVAI, O. V., LAMAKA, S. V., ZHELUDKEVICH, M. L., FERREIRA, M. G. S., Micro-sensores potenciométricos e amperométricos para o estudo da corrosão, Corrosão e Proteção de Materiais, v. 28, 2009.

[50] Manual de Utilização da SVET - GECEA - IST, Alan (Al) Shipley APPLICABLE ELECTRONICS, INC., P.O. Box 589, Forestdale, MA 02644, USA. 
[51] SANTOS, H. O., LIMA, N. B., RODRIGUES, V. A., ROSSI, J. L., MONTEIRO, W. A., Scanning electron microscopic evaluation of etch pitted $\mathrm{Fe}-3 \% \mathrm{Si}$ specimens, Acta Microscopica, Supplement A, 7th Brazilian Conference on Microscopy of Materials, v. 9, 2000.

[52] GODOY, A. L. E., SANTOS, H. O., De MICHELI, L., ROSSI, J. L., COSTA, I., Correlation between corrosion and crystallographic orientation of AISI 316 stainless steel sintered filters, Acta Microscopica, Supplement A, XVIII Congress of the Brazilian Society for Microscopy and Microanalysis, 2001.

[53] HONG, T., NAGUMO, M., Effect of surface roughness on early stages of pitting corrosion of type 301 stainless steel, Corrosion Science, v. 39,p. 16651672, 1997.

[54] PATRIKAR, R. M., Modeling and simulation of surface roughness, Applied Surface Science, v. 228, p. 213-220, 2004.

[55] POURBAIX, M., Electrochemical corrosion of metallic biomaterials, Biomaterials, v. 5, p. 122-133, 1984.

[56] DOWLING, N. J. E., KIM, Y. -H., AHN, S. -K., LEE, Y. -D., Effect of alloying elements and residuals on corrosion resistance of type 444 stainless steel, Corrosion, v. 55, p.187-199, 1999.

[57] FENG, Z., CHENG, X., DONG, C., XU, L., LI, X., Passivity of 316L stainless steel in borate buffer solution studied by Mott-Schottky analysis, atomic absorption spectrometry and $x$-ray photoelectron spectroscopy, Corrosion Science, v. 52, p. 3646-3653, 2010.

[58] BASTOS, A.C., TARYBA, M.G., KARAVAI, O.V., ZHELUDKEVICH, M.L., LAMAKA, S.V., FERREIRA, M.G.S., Micropotentiometric mapping of local distributions of $\mathrm{Zn}^{2+}$ relevant to corrosion studies, Electrochemistry Communications, v. 12, 394-397, 2010.

[59] LAMAKA,S.V., KARAVAI, O.V., BASTOS, A.C., ZHELUDKEVICH, M.L., FERREIRA, M.G.S., Monitoring local spatial distribution of $\mathrm{Mg}^{2+}, \mathrm{pH}$ and ionic currents, Electrochemistry Communications, v. 10, 259-262, 2008.

[60] KALLIP, S., BASTOS, A.C., ZHELUDKEVICH, M.L., FERREIRA, M.G.S., A multi-electrode cell for high-throughput SVET screening of corrosion inhibitors, Corrosion Science, v. 52, 3146-3149, 2010.

[61] QI, J., WANG, K.L., ZHU, Y.M., A study on the laser marking process of stainless steel, Journal of Materials Processing Technology, v. 139, 273-276, 2003.

[62] LEONE, C., GENNA, S., CAPRINO, G., DE IORIO, I., AISI 304 stainless steel marking by a Q-switched diode pumped Nd:YAG laser, v. 210, 1293-1303, 2010. 
[63] GIL, F.J., DELGADO, L., ESPINAR, E., LLAMAS, J.M., Corrosion and corrosion-fatigue behavior of $\mathrm{cp}-\mathrm{Ti}$ and Ti-6Al-4V laser-marked biomaterials, Journal of Materials Science: Materials in Medicine, v. 23, 885-890, 2012. 